UNITED STATES

DEPARTMENT OF THE INTERIOR

GEOLOGICAL SURVEY

\title{
LITHOLOGIC AND BOREHOLE GEOPHYSICAL DATA, GREFN SWAMP AREA, FLORIDA
}

OPEN-FILE REPORT 78.574

Prepared in cooperation with

SOUTHWEST FLORIDA WATER MANAGEMENT DISTRICT

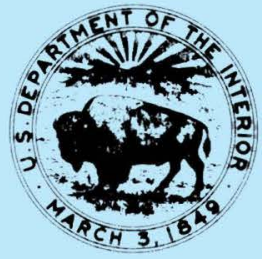


UNITED STATES

DEPARTMENT OF THE INTERIOR

GEOLOGICAL SURVEY

LITHOLOGIC AND BOREHOLE GEOPHYSICAL DATA, GREEN SWAMP AREA, FLORIDA

By Hayes F. Grubb, John W. Chappelear, and

James A. Miller

Open-File Report 78-574

Prepared in cooperation with

SOUTHWEST FLORIDA WATER MANAGEMENT DISTRICT

Tallahassee, Florida 
UNITED STATES DEPARTMENT OF THE INTERIOR

CECIL D. ANDRUS, Secretary

GEOLOGICAL SURVEY

H. William Menard, Director

For additional information write to:

U.S. Geological Survey

Suite F-240

325 John Knox Road

Tallahassee, Florida 32303 
CONTENTS

Page

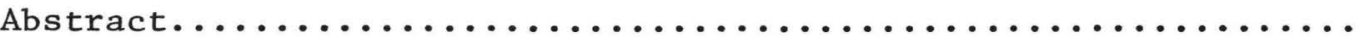

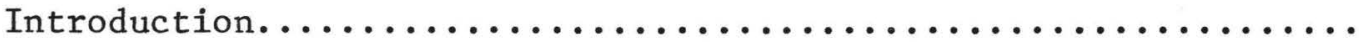

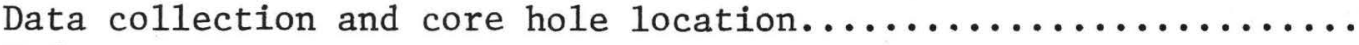

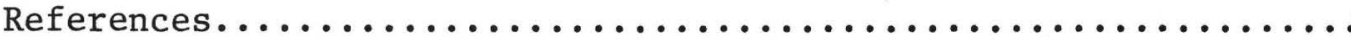

\section{ILLUSTRATIONS}

\section{Figure}

1. Map of Green Swamp area showing location of core holes..

2. -62 . Logs of core holes:

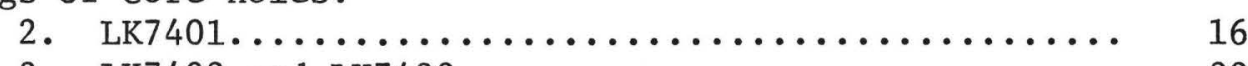

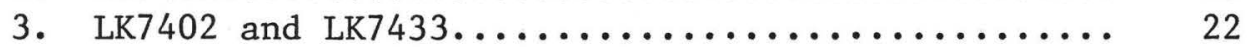

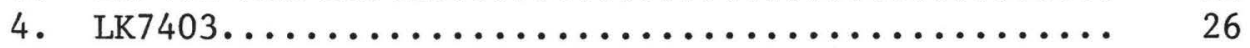

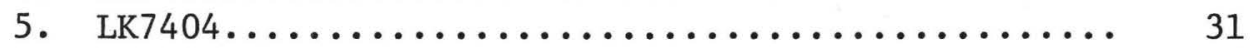

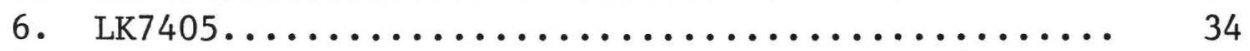

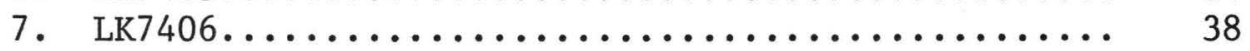

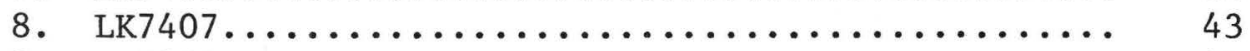

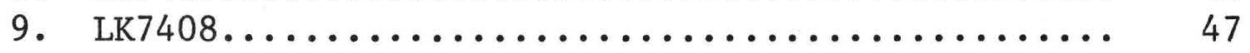

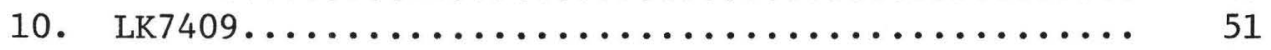

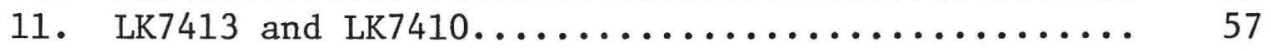

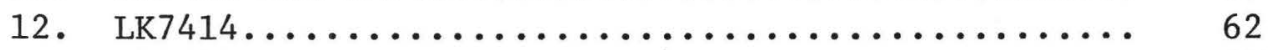

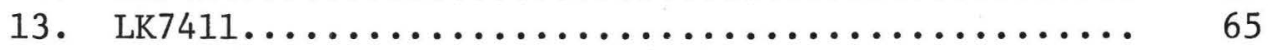

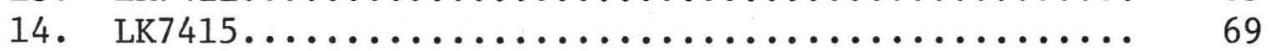

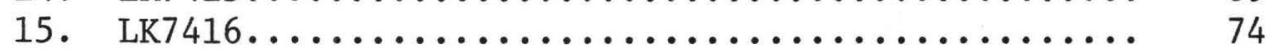

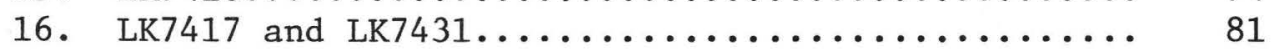

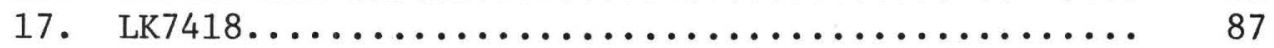

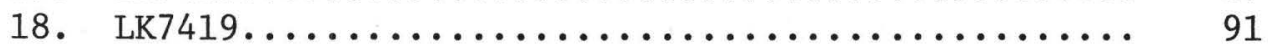

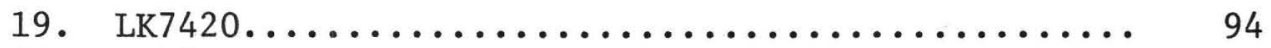

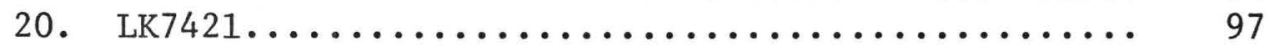

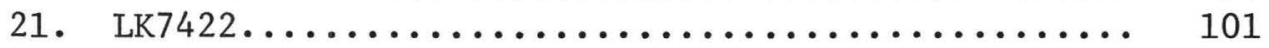

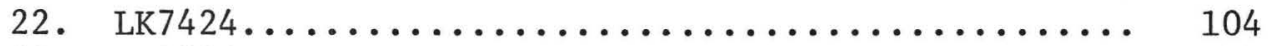

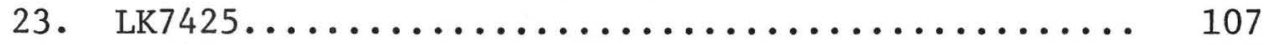

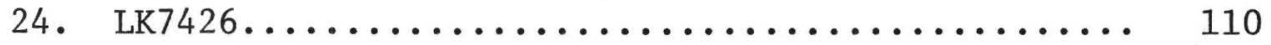

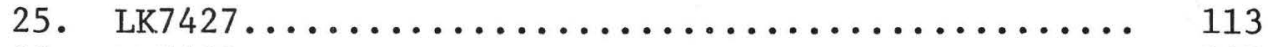

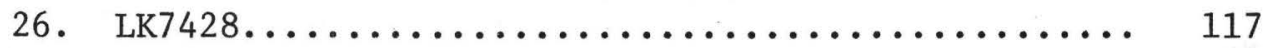

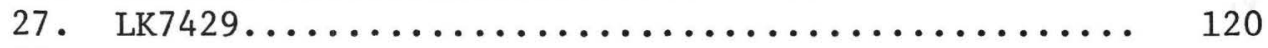

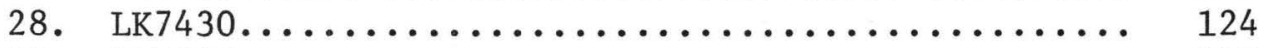

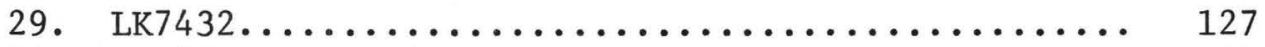

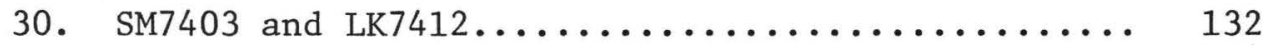

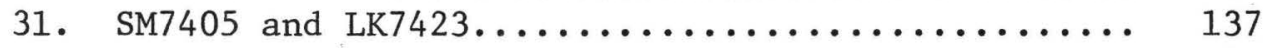

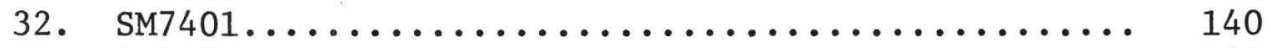

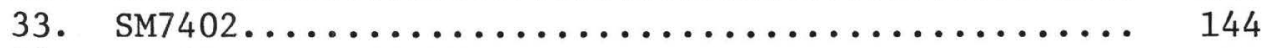

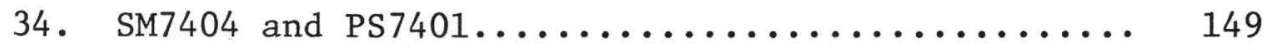

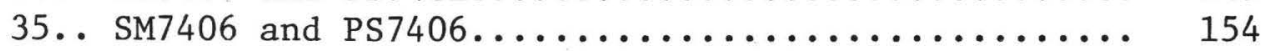

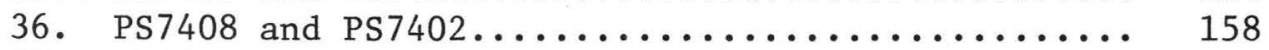

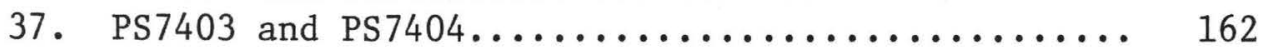

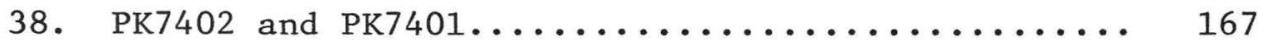




\section{ILLUSTRATIONS (Continued)}

Figure

2.-62. Logs of core holes (Continued):

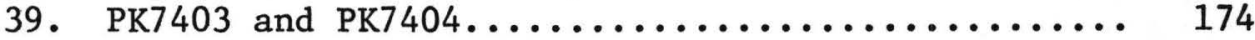

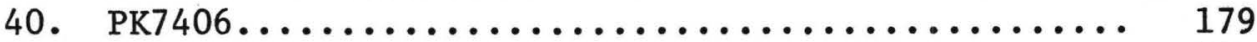

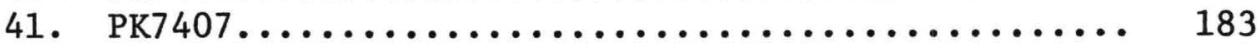

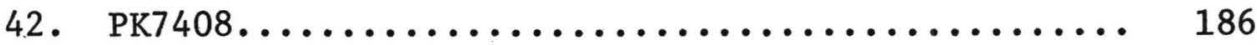

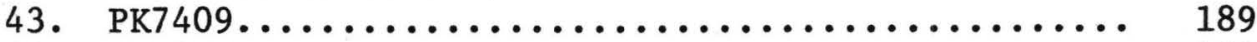

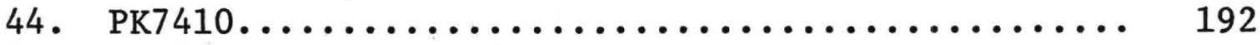

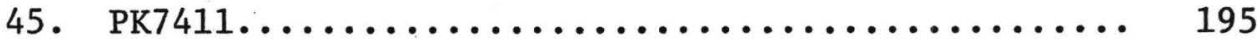

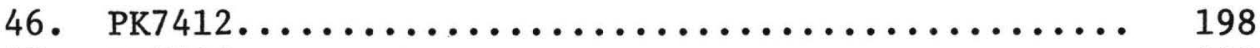

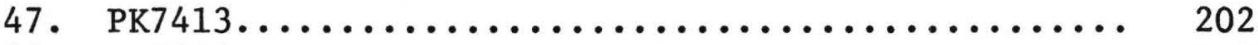

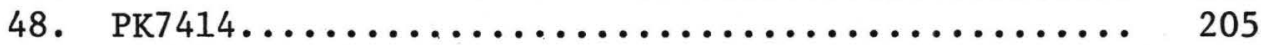

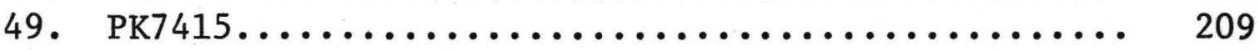

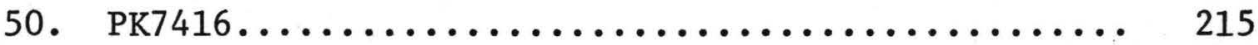

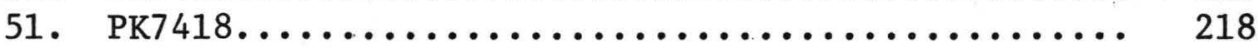

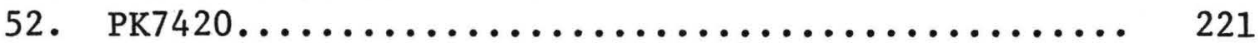

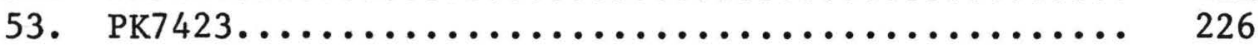

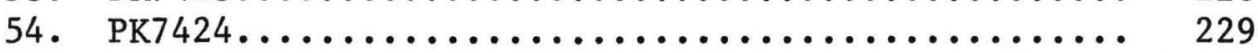

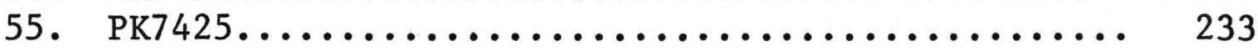

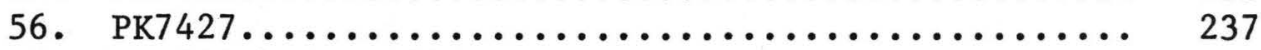

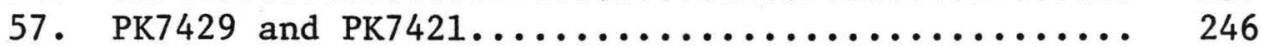

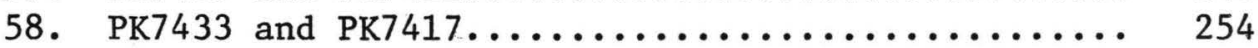

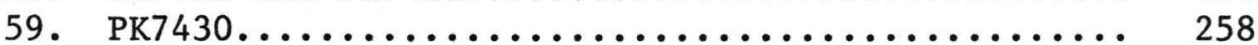

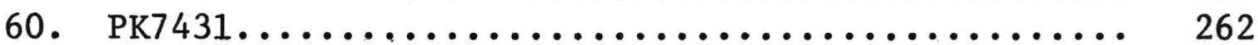

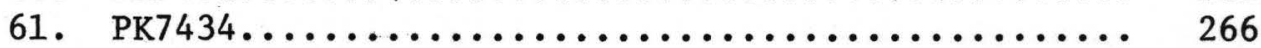

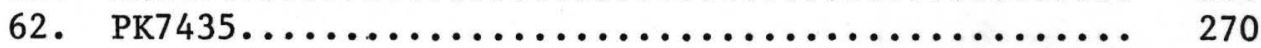

\section{TABLES}

Tab1e

1. Core hole numbers, location, description and depth..... 
Core hole:

Page

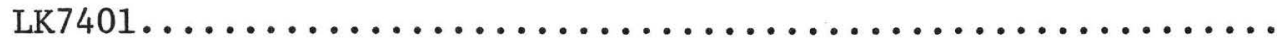

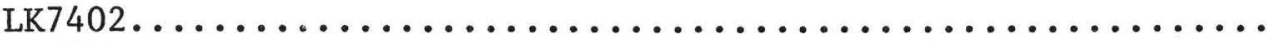

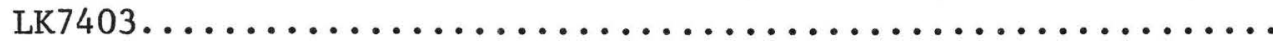

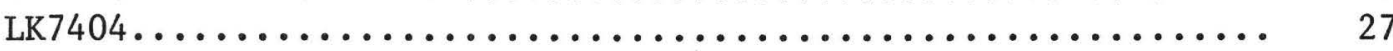

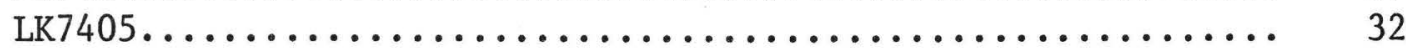

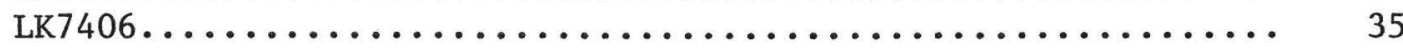

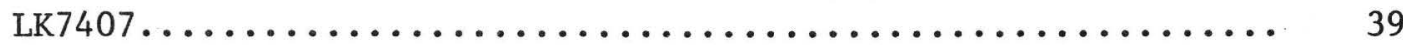

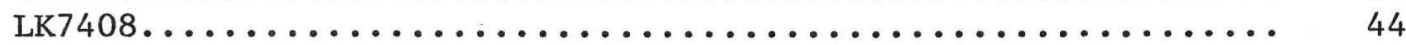

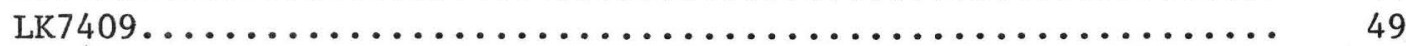

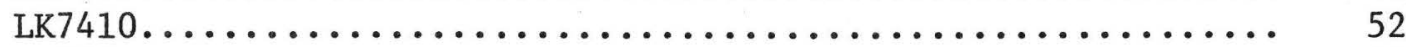

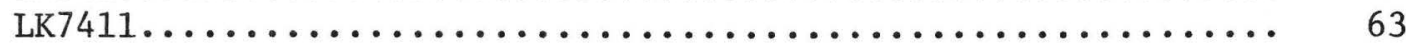

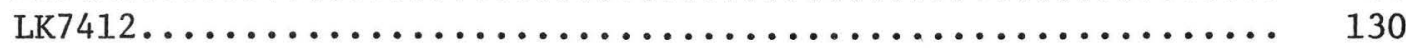

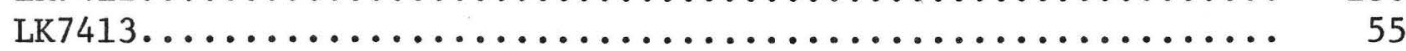

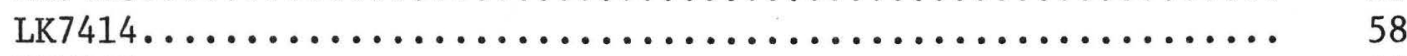

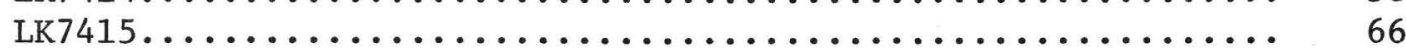

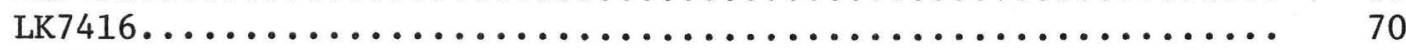

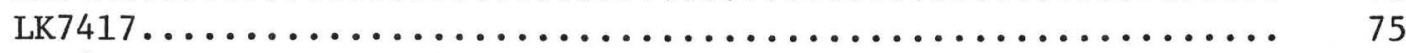

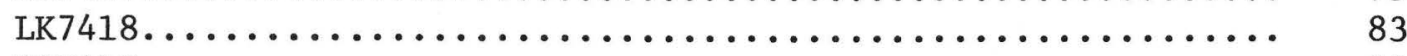

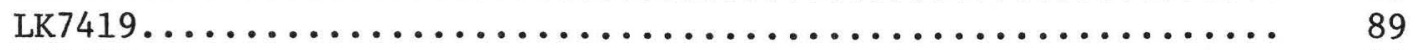

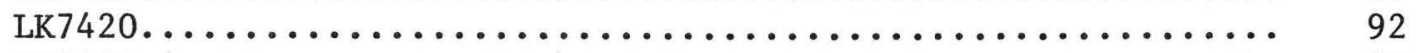

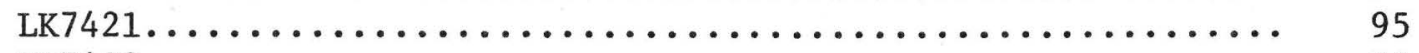

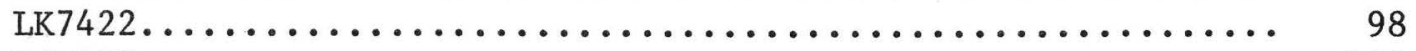

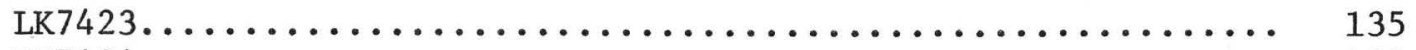

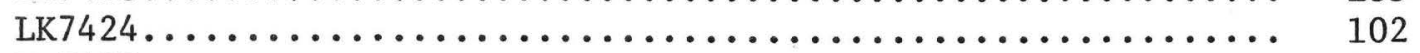

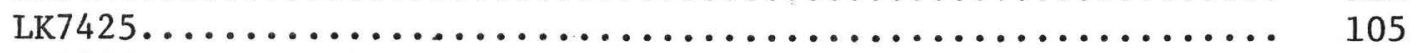

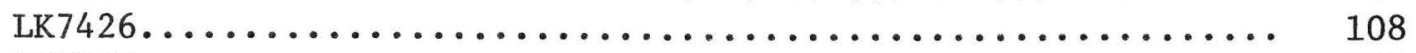

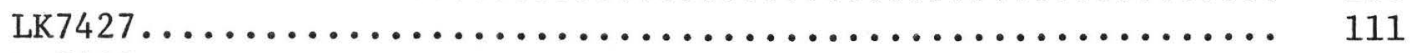

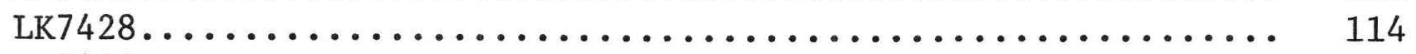

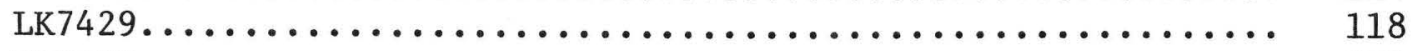

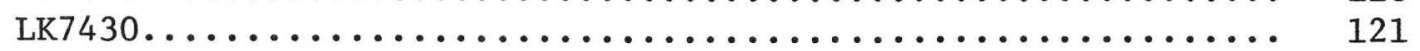

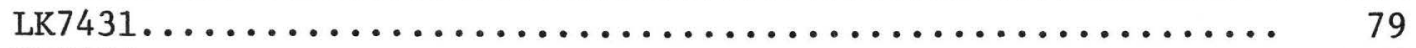

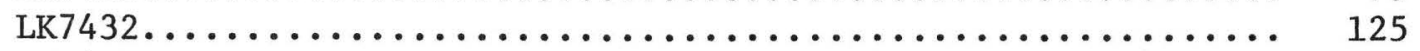

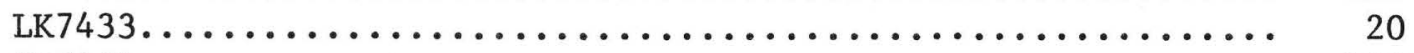

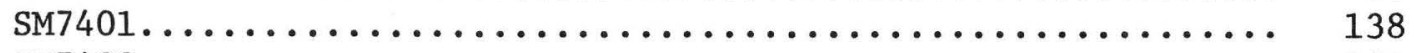

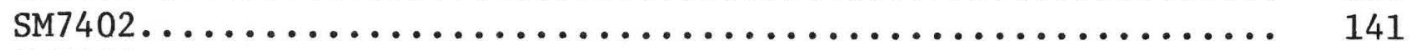

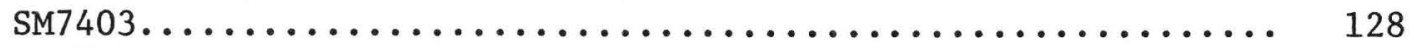

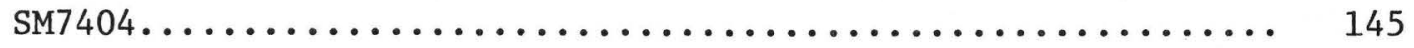

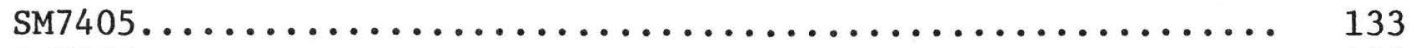

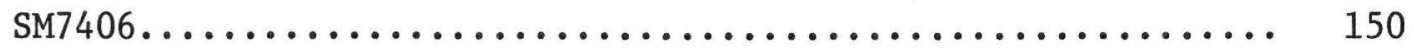

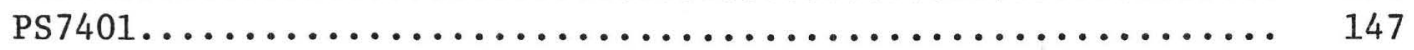

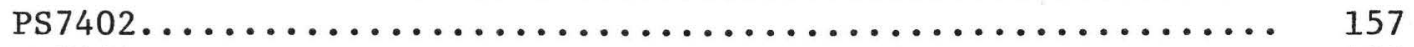

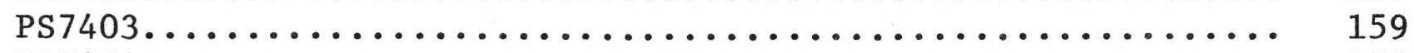

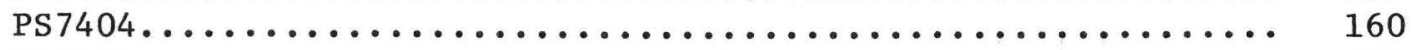

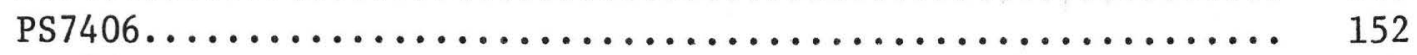

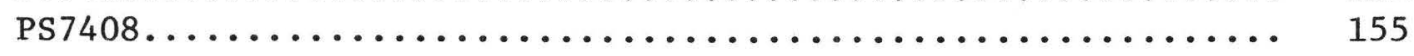




\section{LITHOLOGIC DESCRIPTIONS (Continued)}

Core hole:

Page

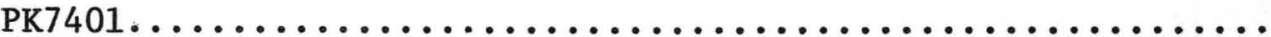

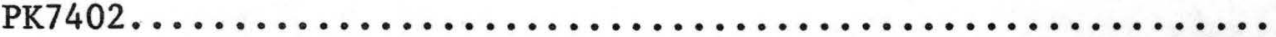

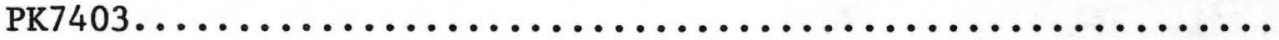

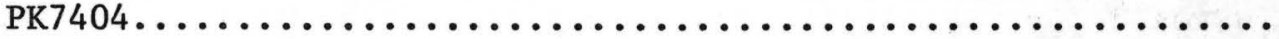

172

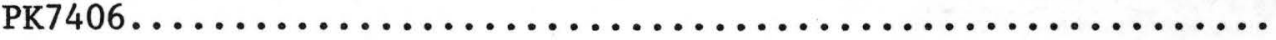

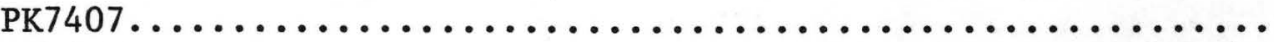

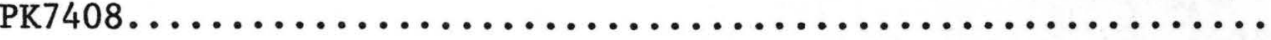

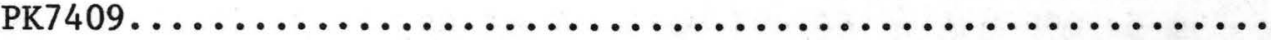

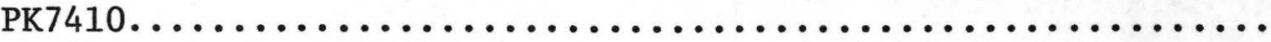

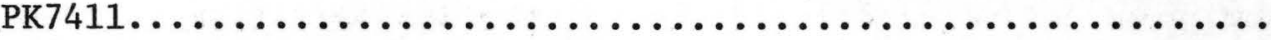

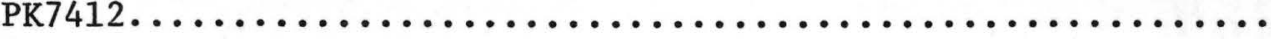

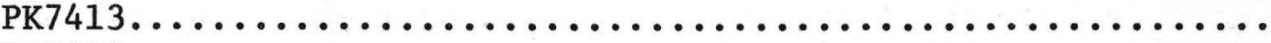

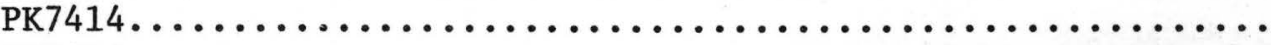

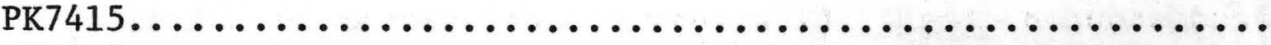

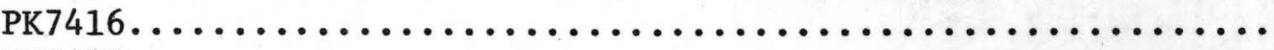

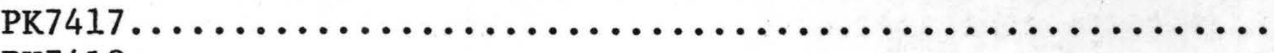

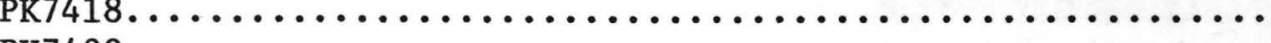

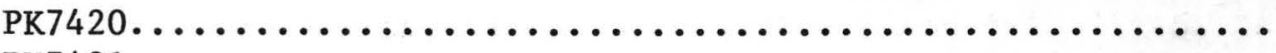

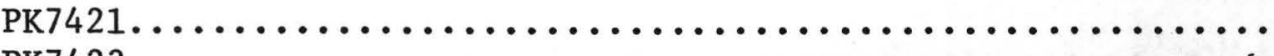

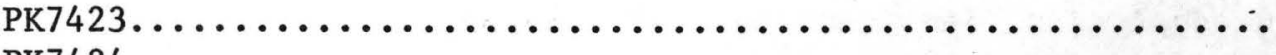

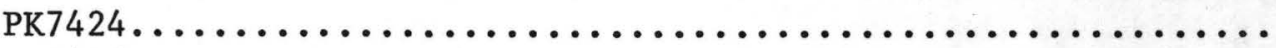

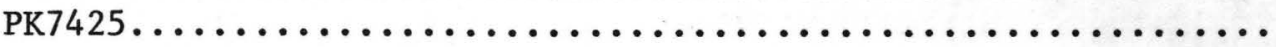

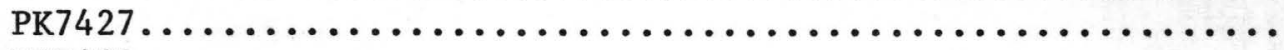

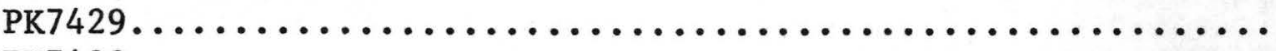

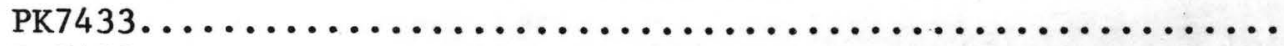

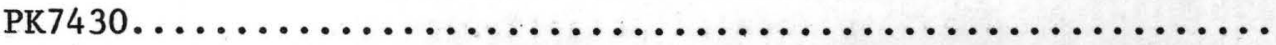

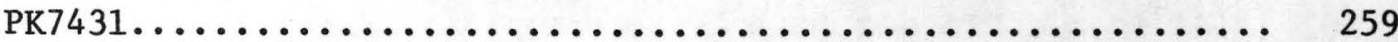

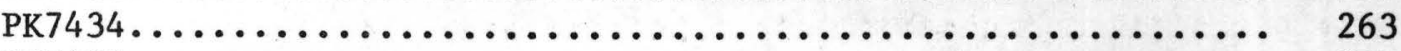

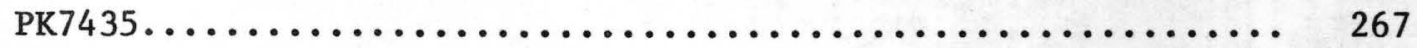




\section{LITHOLOGIC AND BOREHOLE GEOPHYSICAL DATA, GREEN SWAMP AREA, FLORIDA}

By

Hayes F. Grubb, John W. Chappelear, and James A. Miller ABSTRACT

Continuous unconsolidated cores were obtained at 74 sites in the Green Swamp area to evaluate the potential for downward leakage to the Floridan aquifer. Depth of the core holes ranged from 21 to 227 feet and averaged about 87 feet. Lithology was determined by microscopic examination of the core from each hole. Geophysical logs were obtained from 59 of the 74 core holes. This report presents the detailed 1ithologic and geophysical data for these core holes.

INTRODUCTION

Increased use of ground water since the early 1960's in two areas near the Green Swamp area has focused attention on the 1ong-term water supply potential of this sparsely populated area and the hydraulic relationship between the near-surface sediments and the underlying Floridan aquifer. Stewart (1968) and Cherry and others (1970, p. 59, 60 , and 86 ) discussed the effects of ground water withdrawal on water levels in the aquifers and flow of streams in the Middle Gulf area which is located just west of the Green Swamp. Stewart and others (1971) showed the effects of increased ground water use in the phosphate mining area which is located adjacent to and south of the Green Swamp. Robertson (1973, p. 15 and 21) documented the effects of increased withdrawal of ground water in the Lakeland Ridge area which 
is adjacent to the Green Swamp on the southwest. Most of these groundwater supplies are obtained from the Floridan aquifer which is the principal limestone aquifer throughout central Florida.

Pride, Meyer, and Cherry $(1961,1966)$ identified a nonartesian aquifer above the Floridan aquifer in the Green Swamp, with clay confining beds separating the two aquifers. The sandy material above the Floridan aquifer referred to by Pride and others $(1961,1966)$ as the nonartesian aquifer has also been referred to as the clastic aquifer (Knochenmus, 1976, p. 34) and the sand aquifer (Grubb, 1978). The latter designation is used in this report.

The potential for downward leakage from the sand aquifer to the Floridan aquifer was evaluated in an earlier report (Grubb 1978) as a part of the cooperative effort by the U.S. Geological Survey and the Southwest Florida Water Management District to evaluate the long-term water-supply potential of the Green Swamp area.

The detailed data used to make this evaluation were not included in the previous report. The purpose of this report is to present the lithologic and geophysical data in a form which will be useful to those interested in the natural resources of the Green Swamp area. 
DATA COLLECTION AND CORE HOLE LOCATION

The 1ithologic and geophysical data presented herein were obtained from 74 core holes located in the Green Swamp. These holes ranged in depth from 21 to 227 feet and averaged 87 feet deep. Continuous cores of the unconsolidated sediments were obtained from land surface to the top of the Floridan aquifer by rotary drilling with a 4-inch diameter phosphate barrel. The lithology and percentage of sand were determined by microscopic examination of the cores. Geophysical logs were obtained for 59 of the 74 core holes. The detailed lithologic description of the core is presented first, followed by a strip $10 \mathrm{~g}$ and the geophysical logs. The strip logs show the percentage of clay and sand or limestone by standard symbols on a bar graph. The location of each core hole is shown on figure 1, along with a core hole number, geologic age, and stratigraphic designation of the uppermost limestone penetrated. Each core hole number consists of two letters and four numerals assigned to each location prior to drilling. These numbers are cross-referenced in table 1 with the land-net designation and the location according to latitude and longitude. 


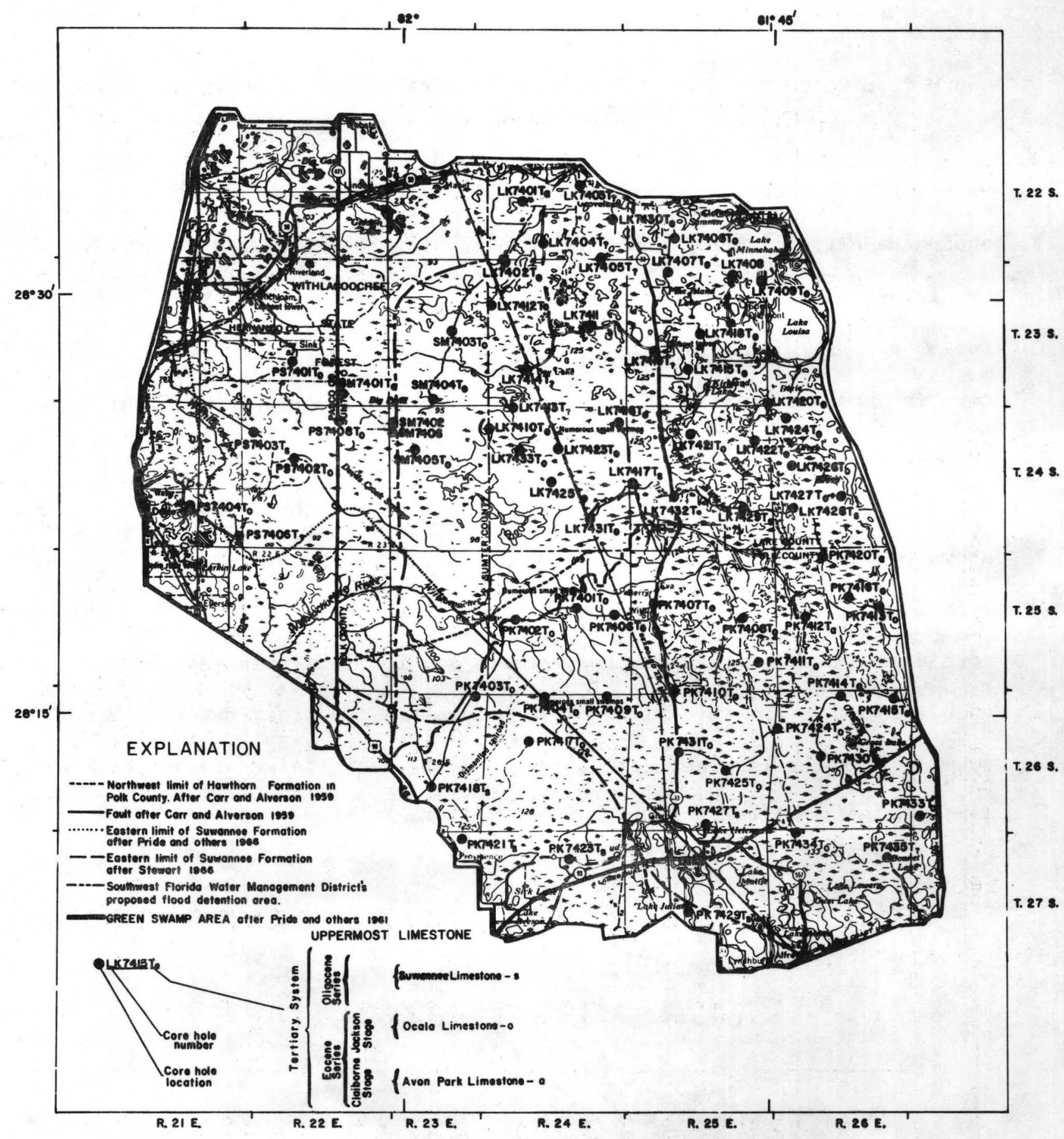

Figure 1.--Green Swamp area and location of core holes. 
Table 1.--Core hole numbers, location, description and depth

\begin{tabular}{|c|c|c|c|c|c|c|c|c|c|}
\hline \multirow{2}{*}{$\begin{array}{l}\text { Core } \\
\text { hole } \\
\text { number }\end{array}$} & \multicolumn{5}{|c|}{ Location } & \multirow{2}{*}{$\begin{array}{l}\text { Date } \\
\text { drilled }\end{array}$} & \multirow[b]{2}{*}{ Depth } & \multirow{2}{*}{$\begin{array}{l}\text { Land } \\
\text { surface } \\
\text { altitude } \\
(\mathrm{ft})\end{array}$} & \multirow{2}{*}{$\begin{array}{l}\text { Log } \\
\text { on } \\
\text { page }\end{array}$} \\
\hline & & wnship & and range & Latitude & Longitude & & & & \\
\hline LK 7402 & 23 & 24 & $6 \mathrm{NW}^{\frac{1}{4}} \mathrm{NE}^{\frac{1}{4}} \mathrm{NE}^{\frac{1}{4}}$ & $283112 \mathrm{~N}$ & 815629.1 & $9-24-74$ & 60 & 101 & 22 \\
\hline LK 7403 & 22 & 24 & $14 \mathrm{SW}^{\frac{1}{4}} \mathrm{SW}^{\frac{1}{4}} \mathrm{SW}^{\frac{1}{4}}$ & $283404 \mathrm{~N}$ & 815317.1 & $9-20-74$ & 83 & 100 & 26 \\
\hline LK 7404 & 22 & 24 & $33 \mathrm{SW}^{1} \frac{1}{4} \mathrm{NW}^{\frac{1}{4}} \mathrm{NE}^{\frac{1}{4}}$ & $283201 \mathrm{~N}$ & 815450.3 & $9-20-74$ & 72 & 105 & 31 \\
\hline LK 7406 & 22 & 25 & $33 \mathrm{NW}^{1} \frac{1}{4} \mathrm{NW}^{1} \frac{1}{4} \mathrm{NW}^{1} \frac{1}{4}$ & $283207 \mathrm{~N}$ & 814921.1 & $9-17-74$ & 81 & 135 & 38 \\
\hline LK 7407 & 23 & 25 & $5 \mathrm{SE}^{\frac{1}{4}} \mathrm{SW}^{\frac{1}{4}} \mathrm{NE}^{\frac{1}{4}}$ & $283054 \mathrm{~N}$ & 814938.1 & $9-16-74$ & 91 & 100 & 43 \\
\hline LK 7408 & 23 & 25 & $2 \mathrm{SE}^{\frac{1}{4}} \mathrm{NE}^{\frac{1}{4}} \mathrm{SW}^{\frac{1}{4}}$ & $283041 \mathrm{~N}$ & 814700.1 & $9-16-74$ & 221 & 150 & 47 \\
\hline LK 7409 & 23 & 25 & $1 \mathrm{SW}^{1} \frac{1}{4} \mathrm{SE}^{\frac{1}{4}} \mathrm{SE}^{1} \frac{1}{4}$ & $283024 \mathrm{~N}$ & 814533.1 & $9-12-74$ & 104 & 115 & 51 \\
\hline LK 7410 & 24 & 24 & $6 \mathrm{SW}^{1} \frac{1}{4} \mathrm{SW}^{1} \frac{1}{4} \mathrm{SW}^{\frac{1}{4}}$ & $282508 \mathrm{~N}$ & 815720.1 & $7-17-74$ & 59 & 105 & 57 \\
\hline LK 7411 & 23 & 24 & $14 \mathrm{SW}^{1} \frac{1}{4} \mathrm{SE}_{\frac{1}{4}}^{1} \mathrm{SW}^{\frac{1}{4}}$ & $282844 \mathrm{~N}$ & 815305.1 & $7-24-74$ & 96 & 107 & 65 \\
\hline LK 7416 & 24 & 24 & $1 \mathrm{NE}^{1} \frac{1}{4} \mathrm{NW}^{1} \frac{1}{4} \mathrm{SE}^{1 / \frac{1}{4}}$ & $282529 \mathrm{~N}$ & 815135.1 & $7-31-74$ & 81 & 112 & 74 \\
\hline LK 7417 & 24 & 25 & $19 \mathrm{SE}^{\frac{1}{4}} \mathrm{NW}^{\frac{1}{4}} \mathrm{NW}^{\frac{1}{4}}$ & $282314 N$ & 815112.1 & $8-06-74$ & 160 & 112 & 81 \\
\hline LK 7418 & 23 & 25 & $15 \mathrm{SW}^{\frac{1}{4}} \mathrm{SW}^{\frac{1}{4}} \mathrm{SW}^{\frac{1}{4}}$ & $282840 \mathrm{~N}$ & 814816.1 & $9-11-74$ & 227 & 105 & 87 \\
\hline LK 7419 & 23 & 25 & $20 \mathrm{SW}^{1} \frac{1}{4} \mathrm{NW}^{1} \frac{1}{4} \mathrm{SW}^{1} \frac{1}{4}$ & $282806 \mathrm{~N}$ & 815014.1 & $7-24-74$ & 72 & 115 & 91 \\
\hline LK 7420 & 23 & 26 & $31 \mathrm{SW}^{\frac{1}{4}} \mathrm{SW}^{\frac{1}{4}} \mathrm{SW}^{\frac{1}{4}}$ & $282608 \mathrm{~N}$ & 814524.1 & $9-06-74$ & 102 & 122 & 94 \\
\hline LK 7421 & 24 & 25 & $9 \mathrm{NW}^{\frac{1}{4}} \frac{\mathrm{S}}{\mathrm{S}} \mathrm{E}^{\frac{1}{4}} \mathrm{NE}^{\frac{1}{4}}$ & $282455 \mathrm{~N}$ & 814837.1 & $7-30-74$ & 71 & 118 & 97 \\
\hline LK 7422 & 24 & 25 & $12 \mathrm{NW}^{1} \frac{1}{4} \mathrm{NE}^{\frac{1}{4}} \mathrm{SW}^{\frac{1}{4}}$ & $282443 N$ & 814602.1 & $9-05-74$ & 97 & 116 & 101 \\
\hline LK 7423 & 24 & 24 & $9 \mathrm{NE}^{\frac{1}{4}} \mathrm{NE}^{\frac{1}{4}} \mathrm{SE}^{\frac{1}{4}}$ & $282435 \mathrm{~N}$ & 815423.1 & $7-18-74$ & 51 & 104 & 137 \\
\hline LK 7424 & 24 & 26 & $6 \mathrm{SE}^{1} \frac{1}{4} \mathrm{NW}^{1} \frac{1}{4} \mathrm{SE}^{1} \frac{1}{4}$ & $282522 \mathrm{~N}$ & 814443.1 & $9-09-74$ & 103 & 115 & 104 \\
\hline LK 7425 & 24 & 24 & $21 \mathrm{NE}^{\frac{1}{4}} \mathrm{NW}^{\frac{1}{4}} \mathrm{NE}^{\frac{1}{4}}$ & $282318 \mathrm{~N}$ & 815440.1 & $7-17-74$ & 47 & 106 & 107 \\
\hline
\end{tabular}


Table 1.--Core hole numbers, location, description and depth-- (Continued)

\begin{tabular}{|c|c|c|c|c|c|c|c|c|c|}
\hline \multirow{2}{*}{$\begin{array}{l}\text { Core } \\
\text { hole } \\
\text { number }\end{array}$} & \multicolumn{5}{|c|}{ Location } & \multirow{2}{*}{$\begin{array}{l}\text { Date } \\
\text { drilled }\end{array}$} & \multirow[b]{2}{*}{ Depth } & \multirow{2}{*}{$\begin{array}{c}\text { Land } \\
\text { surface } \\
\text { altitude } \\
(\mathrm{ft})\end{array}$} & \multirow{2}{*}{$\begin{array}{l}\text { Log } \\
\text { on } \\
\text { page }\end{array}$} \\
\hline & & ownship & and range & Latitude & Longitude & & & & \\
\hline LK 7426 & $\mathrm{~T} .24 \mathrm{~S}$. & R. 26E. & Sec. 18 NW $\frac{1}{4} \mathrm{NE}^{\frac{1}{4}} \mathrm{SE} \frac{1}{4}$ & $282348 \mathrm{~N}$ & 814434.1 & $9-05-74$ & 102 & 127 & 110 \\
\hline LK 7427 & 24 & 26 & $21 \mathrm{NE}^{\frac{1}{4}} \mathrm{SE}^{\frac{1}{4}} \mathrm{SE}^{\frac{1}{4}}$ & $282243 \mathrm{~N}$ & 814226.1 & $8-30-74$ & 112 & 125 & 113 \\
\hline LK 7428 & 24 & 26 & $30 \mathrm{SW}^{\frac{1}{4}} \mathrm{NE}^{\frac{1}{4}} \mathrm{NE}^{\frac{1}{4}}$ & $282219 \mathrm{~N}$ & 814435.1 & $9-03-74$ & 93 & 122 & 117 \\
\hline LK 7429 & 24 & 25 & $26 \mathrm{NW}^{\frac{1}{4}} \mathrm{NE}^{\frac{1}{4}} \mathrm{NE} \frac{1}{4}$ & $28223 ̦ 2 \mathrm{~N}$ & 814640.1 & $9-04-74$ & 102 & 118 & 120 \\
\hline LK 7430 & 22 & 24 & $25 \mathrm{NE}^{\frac{1}{4}} \mathrm{SE}^{\frac{1}{4}} \mathrm{NW}^{\frac{1}{4}}$ & $283247 \mathrm{~N}$ & 815154.1 & $9-18-74$ & 112 & 105 & 124 \\
\hline LK 7431 & 24 & 24 & $26 \mathrm{NE}^{\frac{1}{4}} \mathrm{NE}^{\frac{1}{4}} \mathrm{SW} \frac{1}{4}$ & $282157 \mathrm{~N}$ & 815258.1 & $8-01-744$ & 45 & 103 & 81 \\
\hline LK 7432 & 24 & 25 & $20 \mathrm{NE}^{\frac{1}{4}} \mathrm{SE}_{\frac{1}{4}} \mathrm{SE}^{\frac{1}{4}}$ & $282245 \mathrm{~N}$ & 814926.1 & $9-04-74$ & 81 & 115 & 127 \\
\hline LK 7433 & 24 & 24 & $8 \mathrm{NE}^{\frac{1}{4}} \mathrm{SE}^{\frac{1}{4}} \mathrm{SW}^{\frac{1}{4}}$ & $282425 \mathrm{~N}$ & 815605.1 & $7-18-74$ & 37 & 102 & 22 \\
\hline PS 7401 & 23 & 22 & $26 \mathrm{SE}^{\frac{1}{4}} \mathrm{NW}^{\frac{1}{4}} \mathrm{NW}^{\frac{1}{4}}$ & $282740 \mathrm{~N}$ & 820508.1 & $7-11-74$ & 49 & 77 & 149 \\
\hline PS 7402 & 24 & 22 & $14 \mathrm{SW}^{\frac{1}{4}} \mathrm{NW} \frac{1}{4} \mathrm{NW} \frac{1}{4}$ & $282408 \mathrm{~N}$ & 820514.1 & $7-09-74$ & 42 & 84 & 158 \\
\hline PS 7403 & 24 & 22 & $9 \mathrm{NW}^{1} \frac{1}{4} \mathrm{NE}^{\frac{1}{4}} \mathrm{NW}^{\frac{1}{4}}$ & $282505 \mathrm{~N}$ & 820655.1 & $7-10-74$ & 29 & 74 & 162 \\
\hline PS 7404 & 24 & 21 & $25 \mathrm{SE}^{\frac{1}{4}} \mathrm{NW} \frac{1}{4} \mathrm{NE} \frac{1}{4}$ & $282220 \mathrm{~N}$ & 820933.1 & $7-08-74$ & 54 & 107 & 162 \\
\hline PS 7406 & 24 & 22 & $32 \mathrm{SW}^{\frac{1}{4}} \mathrm{NE}_{\frac{1}{4}}^{\frac{1}{4}} \mathrm{SE}^{\frac{1}{4}}$ & $282109 \mathrm{~N}$ & 820733.1 & $7-09-74$ & 60 & 75 & 154 \\
\hline PS 7408 & 23 & 23 & $6 \mathrm{NW}^{1} \frac{1}{4} \mathrm{NW}^{1} \frac{1}{4} \mathrm{SW} \frac{1}{4}$ & $282532 \mathrm{~N}$ & 820318.1 & $7-10-74$ & 26 & 88 & 158 \\
\hline SM 7401 & 23 & 23 & $31 \mathrm{SW}^{1} \frac{1}{4} \mathrm{DE}^{\frac{1}{4}} \mathrm{NW}^{\frac{1}{4}}$ & $282631 \mathrm{~N}$ & 820303.1 & $7-11-74$ & 99 & 91 & 140 \\
\hline SM 7402 & 24 & 23 & $4 \mathrm{NE}^{\frac{1}{4}} \mathrm{SW}^{1} \frac{1}{4} \mathrm{SW}^{1} \frac{1}{4}$ & $282522 \mathrm{~N}$ & 820109.1 & $7-12-74$ & 97 & 95 & 144 \\
\hline SM 7403 & 23 & 23 & $14 \mathrm{SE}_{\frac{1}{4}}^{1} \mathrm{SE}_{\frac{1}{4}} \mathrm{SE}^{\frac{1}{4}}$ & $282840 \mathrm{~N}$ & 815835.1 & $7-16-74$ & 40 & 100 & 132 \\
\hline SM 7404 & 23 & 23 & $34 \mathrm{SE}_{\frac{1}{4}} \mathrm{NE}^{\frac{1}{4}} \mathrm{SE}^{\frac{1}{4}}$ & $282616 \mathrm{~N}$ & 815921.1 & $7-15-74$ & 24 & 96 & 149 \\
\hline SM 7405 & 24 & 23 & $10 \mathrm{NW}^{1} \frac{1}{4} \mathrm{SE}^{1} \frac{1}{4} \mathrm{SW}^{1} \frac{1}{4}$ & $282430 \mathrm{~N}$ & 815958.1 & $7-15-74$ & 21 & 95 & 137 \\
\hline SM 7406 & 23 & 23 & $9 \mathrm{NE}^{\frac{1}{4}} \mathrm{NW} \frac{1}{4} \mathrm{NW}^{2} \frac{1}{4}$ & $282509 \mathrm{~N}$ & 820108.1 & $7-15-74$ & 40 & 93 & 154 \\
\hline PK 7401 & 25 & 24 & $15 \mathrm{SE}_{\frac{1}{4}}^{\frac{1}{4} \mathrm{SE}^{\frac{1}{4}} \mathrm{NE} \frac{1}{4}}$ & $281839 \mathrm{~N}$ & 815331.1 & $8-09-74$ & 61 & 111 & 167 \\
\hline PK 7402 & 25 & 24 & $17 \mathrm{SE}_{\frac{1}{4}} \mathrm{SW}^{\frac{1}{4}} \mathrm{SW}^{\frac{1}{4}}$ & $281809 \mathrm{~N}$ & 815614.1 & $8-09-74$ & 21 & 110 & 167 \\
\hline PK 7403 & 26 & 23 & $1 \mathrm{NE}^{\frac{1}{4}} \mathrm{NE}^{\frac{1}{4}} \mathrm{NE}^{\frac{1}{4}}$ & $281530 \mathrm{~N}$ & 815730.1 & $8-13-74$ & 157 & 110 & 174 \\
\hline PK 7404 & 26 & 24 & $4 \mathrm{NE}^{\frac{1}{4}} \mathrm{NE} \frac{1}{4} \mathrm{NW} \frac{1}{4}$ & $281531 N$ & 815457.1 & $8-14-74$ & 60 & 117 & 174 \\
\hline PK 7406 & 25 & 24 & $13 \mathrm{NE}^{\frac{1}{4}} \mathrm{SE}^{\frac{1}{4}} \mathrm{SW}^{-1} \frac{1}{4}$ & $281819 \mathrm{~N}$ & 815202.1 & $8-08-74$ & 82 & 115 & 179 \\
\hline
\end{tabular}


Table 1.--Core hole numbers, location, description and depth-- (Continued)

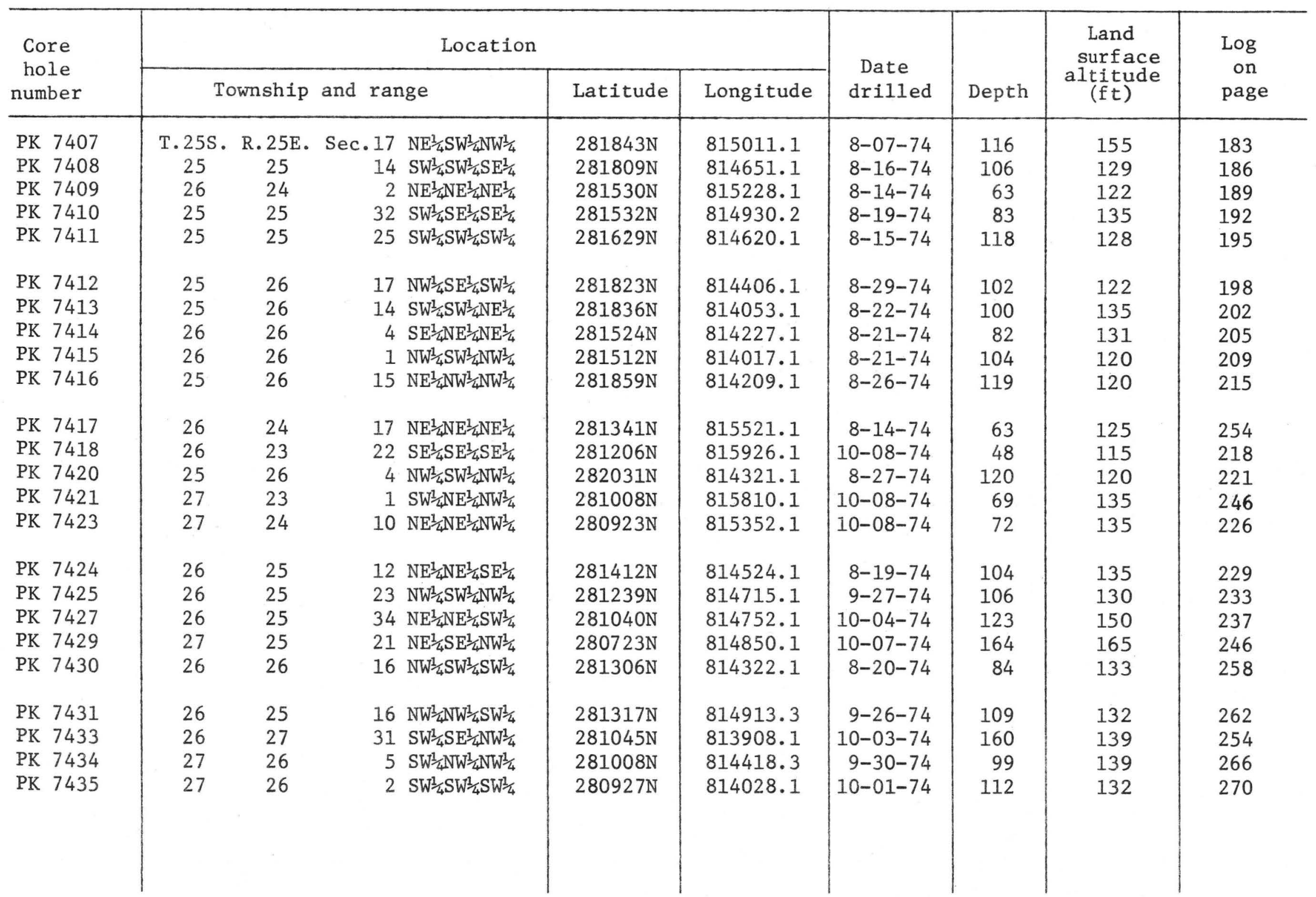


Two types of geophysical logs were obtainedielectric and naturalgamma. The electric logs were obtained with a logging system known as a "differential" single-point system (Keys and MacCary, 1971, p. 31). These logs show the resistance, in ohms, of the sediments and borehole fluid between two inhole electrodes. Single-point logs were especially useful in this study because of their response to changes in 1ithology. The higher resistance, found usual1y in the upper part of the core holes, generally corresponds to sand beds. Clay beds are characterized by low resistance. Limestone may be expressed by either high or intermediate resistance, depending largely on the degree of consolidation of the rock.

The natural-gamma logs represent a measure of the natural-gamma radiation of the earth materials penetrated by the core hole. The sources of natural-gamma radiation in the sediments of the Green Swamp area are the radioisotopes of potassium-40 in clayey strata or the products of the uranium- and thorium-decay series, normally associated with phosphate deposits. Therefore a high natural-gamma count does not necessarily indicate the presence of a clay bed. 


\section{REFERENCES}

Carr, W. J., and Alverson, D. C., 1959, Stratigraphy of middle Tertiary rocks in parts of west-central Florida: U.S. Geo1. Survey Bu11. 1092, 111 p.

Cherry, R. N., Stewart, J. W., and Mann, J. A., 1970, Genera1 hydrology of the Middle Gulf area, Florida: Florida Dept. Nat. Resources, Bur. Geology Rept. Inv. 56, 96 p.

Grubb, H. F., 1978, Potential for downward leakage to the Floridan aquifer, Green Swamp area, central Florida: Tallahassee, F1a., U.S. Geol. Survey Water-Resources Inv. 77-71, map.

Keys. W. S., and MacCary, L. M., 1971, Application of borehole geophysics to water-resources investigations: U.S. Geol. Survey Tech. Water-Resources Inv., book 2, chap. E1, 126 p.

Knochenmus, D. D., and Hughes, G. H., 1976, Hydrology of Lake County, Florida: U.S. Geo1. Survey Water-Resources Inv. 76-72, 100 p. Pride, R. W., Meyer, F. W., and Cherry, R. N., 1961, Interim report on the hydrologic features of the Green Swamp area in central Florida: Florida Geo1. Survey Inv. Circ. 26, 96 p. , 1966, Hydrology of Green Swamp area in central Florida: Florida Geol. Survey Rept. Inv. 42, 137 p. Robertson, A. F., 1973, Hydrologic conditions in the Lakeland Ridge area of Polk County, Florida: Florida Dept. Nat. Resources, Bur. Geology Rept. Inv. 64, 54 p. 


\section{REFERENCES (cont'd.)}

Stewart, J. W., 1968, Hydrologic effects of pumping from the Floridan aquifer in northwest Hillsborough, northeast Pinellas, and southwest Pasco Counties, Florida: U.S. Geo1. Survey open-file report.

Stewart, J. W., Mills, L. R., Knochenmus, D. D., and Faulkner, G. L., 1971, Potentiometric surface and areas of artesian flow, May 1969, and change of potentiometric surface 1964 to 1969, Floridan aquifer, Southwest Florida Water Management District, Florida: U.S. Geol. Survey Hydrol. Inv. Atlas HA-440. 
Lake County 283331N0815540.1

DEPTH INTERVAL (feet)

$3.0-12.0$

$12.0-20.5$

$20.5-21.0$

$21.0-22.5$

$22.5-25.5$

$22.5-27.5$

$27.5-28.0$

$28.0-29.0$

$29.0-30.5$

$30.5-31.5$

\section{LITHOLOGY}

\section{Post Miocene Rocks}

Sand, light gray, clear to frosted, medium-to coarsegrained. Just enough medium gray clay to bind sand 1oose1y.

$55 \%$ light brown, clear to stained, medium-grained, fairly well sorted sand; 35\% light and dark brown mottled, indurated, crumbly clay matrix; $10 \%$ coarsegrained sand.

$50 \%$ white to light brown, clear to stained, mediumgrained, fairly well sorted, sub-rounded sand; $40 \%$ light and dark brown, mottled, poorly consolidated clear matrix; $10 \%$ coarse-grained sand.

White, clear to frosted, medium-to coarse-grained sand, with light brown tint. Trace of heavy minerals.

$70 \%$ sand as above; $30 \%$ tan, fairly well consolidated clay matrix.

No sample.

$-80 \%$ sand as $20.5-21.0$ interval; $20 \%$ light tan and white mottled soft clay matrix.

95\% white to light gray, clear to frosted, medium-to coarse-grained, rounded sand. $5 \%$ very coarse-grained sand. Trace of heavy minerals and light tan clay.

$75 \%$ sand as above; $25 \%$ light brown, soft, fairly we11 consolidated clay matrix.

$75 \%$ white, clear to frosted, fine to medium-grained, angular to sub-rounded sand; $25 \%$ tan, soft, fairly well consolidated, slightly crystalline, clay matrix. Trace of heavy minerals.

As above, with clay matrix light tan and brown mottled. 
$31.5-32.0$

$32.0-35.0$

$35 \cdot 0-38 \cdot 0$

$38.0-39.0$

$39.0-40.5$

$40.5-41.5$

$41.5-43.0$

$43.0-45.0$

$45.0-48.0$

$48.0-49.0$

$49.0-49.5$

$49.5-50.0$
$90 \%$ white to light gray, clear to frosted, mediumgrained, fairly we11 sorted, sub-rounded sand; $10 \%$ coarse-grained sand. Trace of heavy minerals.

$95 \%$ light greenish blue, soft, waxy clay matrix. $5 \%$ white, clear, fine-to medium-grained, angular to subangular sand. Pockets of pure sand in upper 1 foot of interval.

$55 \%$ white to light gray, clear to frosted, medium-to coarse-grained, rounded sand; $25 \%$ fragments of white microcrystalline, hard, porous, silicified limestone containing minor relic fossil material; $20 \%$ tan and light gray mottled, poorly consolidated clay matrix.

$70 \%$ white to 1 ight brown, clear to stained, medium-to coarse-grained, rounded sand; $30 \%$ tan and light green mottled, soft clay matrix. Trace of limestone.

As above with minor mottling of dark brown, pure waxy clay.

$40 \%$ white sand as $38.0-39.0$ interval; $40 \%$ dark brown, soft clay matrix; $20 \%$ limestone.

$65 \%$ sand as $38.0-40.5$ interval; $30 \%$ dark brown, fairly well consolidated clay matrix, mottled with pure, very dark brown, well consolidated, waxy clay; 5\% limestone.

No sample.

$55 \%$ white to light gray to light brown, clear to stained, fine-to medium-grained, angular to sub-rounded sand; $35 \%$ medium and very dark brown mottled, indurated, fairly we11 consolidated clay matrix; $5 \%$ coarse-grained sand; $5 \%$ white to brown, microcrystalline, hard, porous, silicified limestone with relic fossil material.

As above with decrease in sand to $40 \%$; increase in clay to $50 \%$; increase in limestone to $10 \%$, a few black clay streaks with a trace of marcasite.

$50 \%$ white, clear to frosted, medium-grained sand; $50 \%$ medium gray, dark and light brown mottled and banded, indurated, well consolidated clay matrix.

95\% 1ight brown and 1ight gray mottled, soft, wel1 consolidated clay matrix; $5 \%$ white to light brown, clear to frosted, medium-grained sand. 
$50.0-52.0$

$52.0-52.5$

$52.5-53.0$

$53.0-55.0$

$55.0-56.0$

$56.0-56.5$

$56.5-57.0$

$57.0-60.0$

$60.0-61.0$

$61.0-62.0$
$50 \%$ light gray to light brown, clear to stained, medium-grained, fairly well sorted, sub-rounded sand; $40 \%$ medium brown and dark gray mottled, soft to indurated, fairly well consolidated clay matrix; $5 \%$ coarse-grained sand; $5 \%$ white to light gray microcrystalline, indurated, porous, silicified limestone, with minor relic fossil material. A few large fragments of limestone.

$50 \%$ sand as above; $40 \%$ medium gray, soft clay matrix; $10 \%$ limestone as above, with a few large fragments of limestone.

$70 \%$ off-white, clear to frosted, fine-to coarsegrained, angular to sub-rounded sand; $30 \%$ light brown, dark brown and medium gray banded, soft, poorly consolidated clay.

$60 \%$ dark gray, soft clay matrix with minor light brown mottling; 35\% light gray with light brown tint, clear to stained, medium-grained, fairly well sorted, subrounded sand; 5\% fine and coarse-grained sand.

As above with trace of silicified limestone, clay is medium brown with minor medium gray mottling.

$60 \%$ sand and limestone as above; $40 \%$ light and dark brown mottled, indurated clay matrix with minor dark gray mottling.

$50 \%$ white, clear to frosted, medium-grained, fairly we11 sorted, sub-rounded sand; $50 \%$ medium brown, we11 consolidated clay matrix.

As above, trace of white to light brown, microcrystalline, hard, silicified limestone.

$50 \%$ white to light brown, clear to frosted, mediumgrained, well sorted, sub-rounded sand; $50 \% 1$ light and dark brown mottled, indurated clay, with minor dark gray mottling, trace of white and light brown mottled microcrystalline, indurated, silicified limestone with scattered relic fossils.

$70 \%$ 1ight brown and dark gray mottled, soft clay matrix; $25 \%$ sand as $60.0-61.0$; $5 \%$ white microcrystalline, indurated, silicified limestone. 
$62.0-63.0$

$63.0-64.0$

$64.0-72.0$

$72.0-74.0$

$74.0-79.0$

$79.0-83.0$

$83.0-87.5$

$87.5-89.0$

$89.0-92.5$

$92.5-93.0$

$93.0-95.5$

$95.5-98.0$
$50 \%$ dark greenish gray, soft clay matrix; $40 \%$ sand as $49.550 .0 ; 10 \%$ limestone as $45.0-48.0$, trace of marcasite.

$60 \%$ black, soft, waxy clay matrix; $35 \%$ sand as above; $5 \%$ coarse-grained sand.

No sample.

$98 \%$ dark gray, soft, waxy clay; $2 \%$ light gray, clear to stained, medium-grained, fairly well sorted, sub-rounded sand, trace of limestone as 45.0-48.0.

$50 \%$ light tan, clear to stained, coarse-to mediumgrained, sub-rounded sand; $50 \%$ dark gray and dark brown mottled, indurated clay matrix, trace of limestone as $45.0-48.0$.

As above with increase in limestone to $15 \%$, corresponding decrease in sand.

40\% dark gray and dark brown mottled, soft clay matrix; $35 \%$ sand as $74.0-79.0 ; 25 \%$ fragments of off-white and light gray mottled, microcrystalline, indurated silicified limestone, with relic fossil material

$60 \%$ medium brown and dark gray mottled, soft clay matrix; $30 \%$ white, clear to frosted, fine-to mediumgrained, angular to sub-rounded sand; $10 \%$ white, very fine-grained, indurated, silicified limestone, with relic fossil material.

$60 \%$ light tan, clear to frosted, medium-grained, fairly we11 sorted, sub-rounded sand; $30 \%$ dark gray and dark brownish gray mottled, indurated, clay matrix; $10 \%$ coarse-grained sand.

$95 \%$ light brown and dark gray mottled, soft, waxy clay matrix; $5 \%$ sand as above.

$50 \%$ sand as $89.0-92.5$; $50 \%$ dark gray, soft, waxy clay, mottled with pockets of fairly pure sand.

\section{Rocks of Miocene Age}

$50 \%$ light and dark brown and dark gray mottled, soft clay matrix; $25 \%$ white, clear to frosted, fine to coarse-grained, angular to sub-rounded sand; $25 \%$ small fragments of very light gray, microcrystalline, indurated, fossiliferous limestone. 


\section{Rocks of Eocene Age}

$98.0-99.0$

$60 \%$ creamy, soft, highly weathered, microcrystalline coquina, with pockets of sand as above in matrix of $40 \%$ light gray clay.

$99.0-102.8$

$70 \%$ 1imestone as above, pockets of sand as above in matrix of $30 \%$ dark brown clay, contains Pseudorbitolina cubensis (Cushman and Bermudez) and Discorbis inornatus (Cole). 


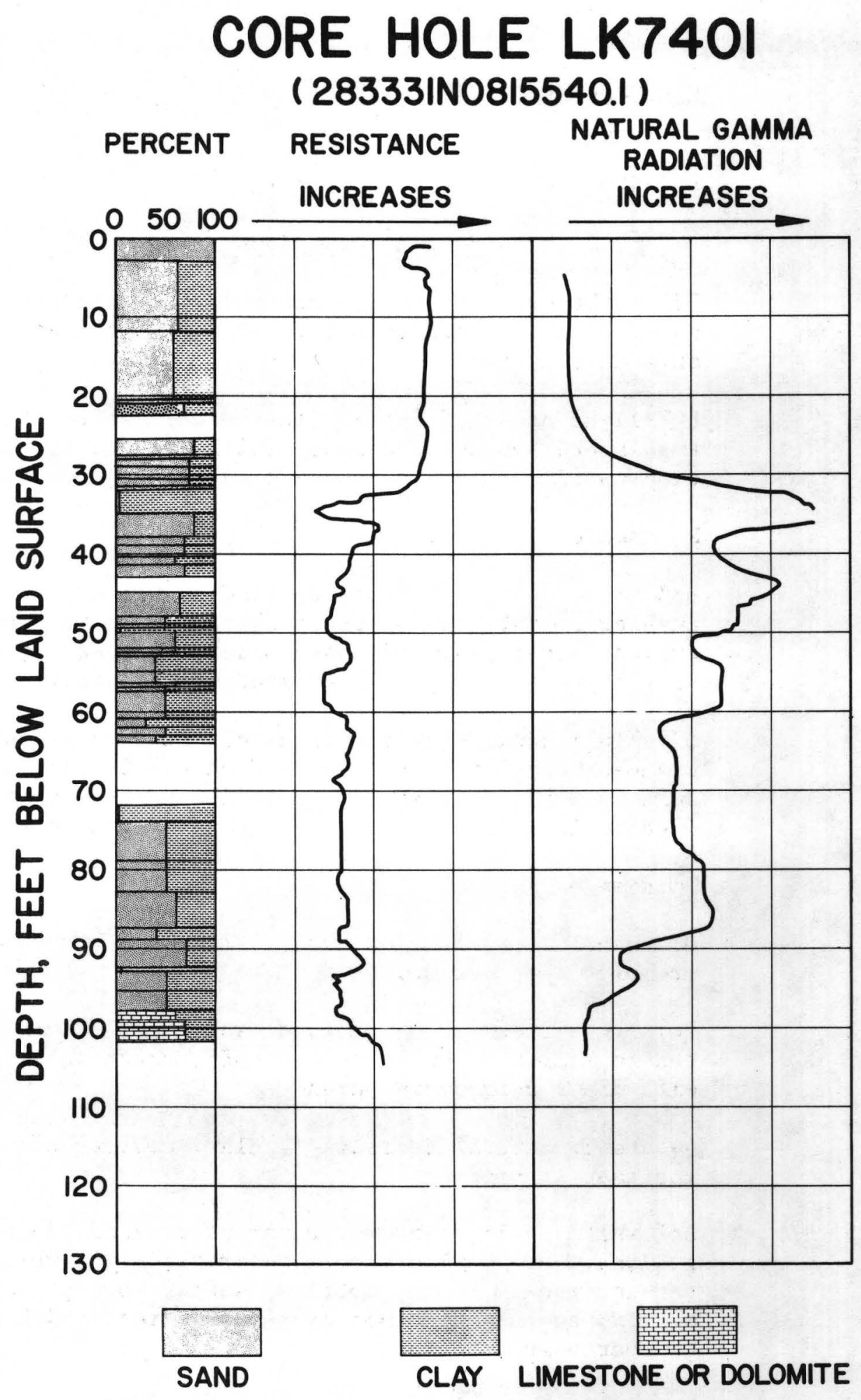


LK7402

Lake County $\quad$ 283112N0815629.1

DEPTH INTERVAL (feet)

$1.0-2.0$

$2 \cdot 0-6.0$

$6.0-6.5$

$6.5-7.5$

$7.5-10.5$

$10.5-11.5$

$11.5-12.2$

$12.2-12.5$

$12.5-13.5$

$13 \cdot 5-14.5$

\section{LITHOLOGY}

\section{Post Miocene Rocks}

$75 \%$ light gray, frosted, medium to coarse-grained, sub-rounded to rounded sand; $25 \%$ medium gray, indurated clay matrix.

$85 \%$ light brown, frosted, fine to medium-grained, angular to sub-rounded sand; $10 \%$ light brown, soft clay matrix; $5 \%$ coarse to very coarse-grained sand.

No sample.

95\% white, clear to frosted, find to medium-grained, angular to sub-rounded sand; $5 \%$ coarse to very coarsegrained sand; trace of heavy minerals; just enough very light tan clay to bind sand very loosely.

$65 \%$ light brown, clear to stained, fine to mediumgrained, angular to sub-rounded sand; $30 \%$ dark brown, soft, crumbly clay matrix, containing streaks of black organic material; $5 \%$ coarse to very coarse- grained sand.

No sample.

$85 \%$ sand as $6.5-7.5$ interval; $15 \%$ medium brown, soft, crumbly, clay matrix.

$70 \%$ light brown to white sand, as above; $30 \%$ very light tan to medium brown, mottled, soft, crumbly clay matrix with minor dark brown streaks.

As above, with $5 \%$ decrease in clay; corresponding increase in sand.

$65 \%$ white to light brown, clear to stained, finegrained, very well sorted angular sand; $25 \%$ very light tan and medium brown, mottled, soft, crumbly clay matrix, containing minor dark gray streaks; $10 \%$ medium to coarse-grained sand.

No sample. 
$14 \cdot 5-15.5$

$15.5-16.7$

$16.7-17.5$

$17.5-19.5$

$19 \cdot 5-21.5$

$21.5-23.0$

$23.0-24.0$

$24.0-24.5$

$24.5-25.5$

$25 \cdot 5-27.0$

$27.0-29.0$

$29.0-29.5$
$60 \%$ white to clear, fine-grained, fairly we 11 sorted, angular sand; $30 \%$ creamy, indurated clay matrix; $10 \%$ medium to coarse-grained sand.

$65 \%$ white to clear, fine to medium-grained, angular to sub-rounded sand; $35 \%$ very light tan to dark brown mottled, indurated clay matrix. Scattered coarse to very coarse-grained sand.

$70 \%$ sand, as above; $30 \%$ creamy, very light brown, mottled, indurated, crumbly clay matrix; trace of heavy minerals.

$60 \%$ white, clear, fine-grained, well sorted angular sand; 40\% light tan, soft, waxy clay matrix; trace of heavy minerals.

$70 \%$ white to clear, fine to medium-grained, angular to sub-rounded sand; $30 \%$ off-white, indurated, powdery clay matrix; trace of heavy minerals.

$80 \%$ pale green, soft, waxy clay matrix with minor dark brown bandings; $20 \%$ sand as above; trace of heavy minerals; a $1 / 2-i n c h$ very sandy layer is present in the lower 0.5 foot of the interval.

$65 \%$ sand, as 19.5-21.5 interval; $35 \%$ light tan, indurated clay matrix; trace of heavy minerals.

$75 \%$ 1ight, greenish gray, soft, waxy clay; $25 \%$ sand, as above; trace of heavy minerals and white phosphate.

$70 \%$ white, clear to frosted, medium-grained, very well sorted, sub-angular, to sub-rounded sand; $30 \%$ light, greenish gray, soft clay matrix with minor dull orange streakings; trace of heavy minerals.

$50 \%$ white, clear, fine to medium-grained, angular to sub-rounded sand; 50\% light, greenish gray, soft, waxy clay; integrated with pure light greenish-gray, soft, waxy clay.

$80 \%$ sand as 24.5-25.5 interval; $20 \%$ pale green, soft clay; trace of heavy minerals.

$50 \%$ white, clear, fine-grained, fairly we11 sorted, angular sand; $25 \%$ medium-grained sand; $25 \%$ light tan to medium brown, mottled, soft clay matrix, with minor mottled black soft clay; trace of heavy minerals. 
$29.5-32.0$

$32.0-33.0$

$33.0-34.0$

$34.0-38.5$

$38.5-40.0$

$40.0-41.0$

41. 0-42. 5

$42.5-49.5$

$49.5-60.0$
$60 \%$ pale green, soft, waxy clay matrix; $40 \%$ sand, as above; a 2-inch band of fine-grained, well sorted, angular sand with just enough light purple clay to bind sand loosely occurs at 31.2 feet.

$50 \%$ pale green, soft clay, with thin integrated white, clear, fine-grained, well sorted angular sand; $35 \%$ sand as $29.0-29.5$ interval; $15 \%$ of f-white soft clay.

$90 \%$ sand as $29.0-29.5$ interval; $10 \%$ white, indurated, crumbly clay matrix; trace of heavy minerals.

No sample.

$65 \%$ sand, as 29.0-29.5 interval; $35 \%$ off-white, indurated to soft clay matrix.

\section{Rocks of Miocene Age}

$60 \%$ pale green, indurated clay; $25 \%$ fine to coarse white phosphate nodules; $15 \%$ off-white, clear to frosted, fine to medium-grained sand, in white to pale green, mottled, soft clay matrix.

$50 \%$ light green to light brown, banded, indurated clay matrix; $40 \%$ fine to very coarse, light tan phosphate nodules; $10 \%$ sand, as above.

No sample.

\section{Rocks of Eocene Age}

$60 \%$ small fragments of creamy, microcrystalline, hard, porous limestone and light brown to light gray mottled, cryptocrystalline, hard, tight, silicified limestone containing relic fossil material; $20 \%$ white, clear to frosted, fine to medium-grained sand; $20 \%$ very large foraminifera; trace of black to brown to tan, fine to coarse phosphate nodules, pisolitic silica, highly weathered. 
Lake County $\quad 282425$ N0815605.1

DEPTH INTERVAL (feet)

$0.0-0.5$

$0.5-1.5$

$1.5-2.0$

$2.5-5.0$

$5 \cdot 0-7.5$

$7.5-11.0$

$11.0-15.5$

$15.5-18.0$

$18.0-21.0$

\section{LITHOLOGY}

\section{Post Miocene Rocks}

$50 \%$ white to light gray, clear to frosted, medium to fine-grained, fairly well sorted, sub-rounded to subangular quartz sand; $50 \%$ light, soft, highly organic clay matrix, trace of heavy minerals.

As above with trace of light gray clay.

Off-white, clear to frosted, medium to fine-grained, fairly well sorted, sub-angular to sub-rounded quartz sand, trace of heavy minerals.

$60 \%$ white to light gray, clear to frosted, medium to fine grained, fairly well sorted, sub-rounded to subangular quartz sand; $40 \%$ dark gray, soft clay matrix, trace of heavy minerals.

Light tan, clear to frosted, medium to fine-grained, fairly well sorted, sub-rounded to sub-angular quartz sand, trace of heavy minerals.

$90 \%$ white to light tan, clear to frosted, medium-grained, poorly sorted, sub-rounded quartz sand; $10 \%$ light brown, clay matrix with minor white mottling, trace of heavy minerals.

$70 \%$ white, clear to frosted, medium grained, poorly sorted, sub-rounded quartz sand; $30 \%$ light to dark brown, mottled and banded, soft clay matrix, trace of heavy minerals.

$60 \%$ white, clear to frosted, medium-grained, fairly we11 sorted, angular quartz sand; $40 \%$ light to medium brown, gray mottled, soft clay matrix, trace of fine-grained muscovite flakes.

As above. 
$21.0-24.0$

$24.0-26.0$

$26.0-27.0$

$27.0-28.0$

$28.0-31.0$

$31.0-34.0$

$34.0-37.0$
$65 \%$ white, clear to frosted, fine-grained, fairly we11 sorted, angular quartz sand; $35 \%$ medium brown and light tan mottled and banded, indurated clay matrix, trace of heavy minerals and fine-grained muscovite flakes. Last 0.4 foot of interval is composed of very light gray, indurated, powdery clay.

$75 \%$ white, clear, fine grained, angular quartz sand; $25 \%$ light to medium brown, mottled, soft clay matrix, trace of heavy minerals and foraminifera.

\section{Rocks of Eocene Age}

$60 \%$ off-white, soft, fairly well consolidated, calcareous clay matrix; $40 \%$ off-white, large to small foraminifera, including Echinocythereis okeechobiensis (Swain), Lepidocyclina ocalana floridana (Cushman), Cibicides mississippiensis ocalanus (Cushman), and Reusse1la sculptilis (Cushman).

$50 \%$ white, clear, fine to medium-grained, poorly sorted quartz sand; $50 \%$ dark to medium brown mottled, soft clay matrix that has creamy, soft, calcareous clay inclusions.

$50 \%$ white, clear, fine-grained, well sorted, angular quartz sand; $50 \%$ greenish gray, soft clay matrix; trace of heavy minerals.

$50 \%$ creamy, soft, calcareous clay matrix; $35 \%$ creamy microcrystalline, indurated, porous, fossiliferous, chalky limestone, $15 \%$ fine to medium-grained, clear quartz sand.

No sample. 


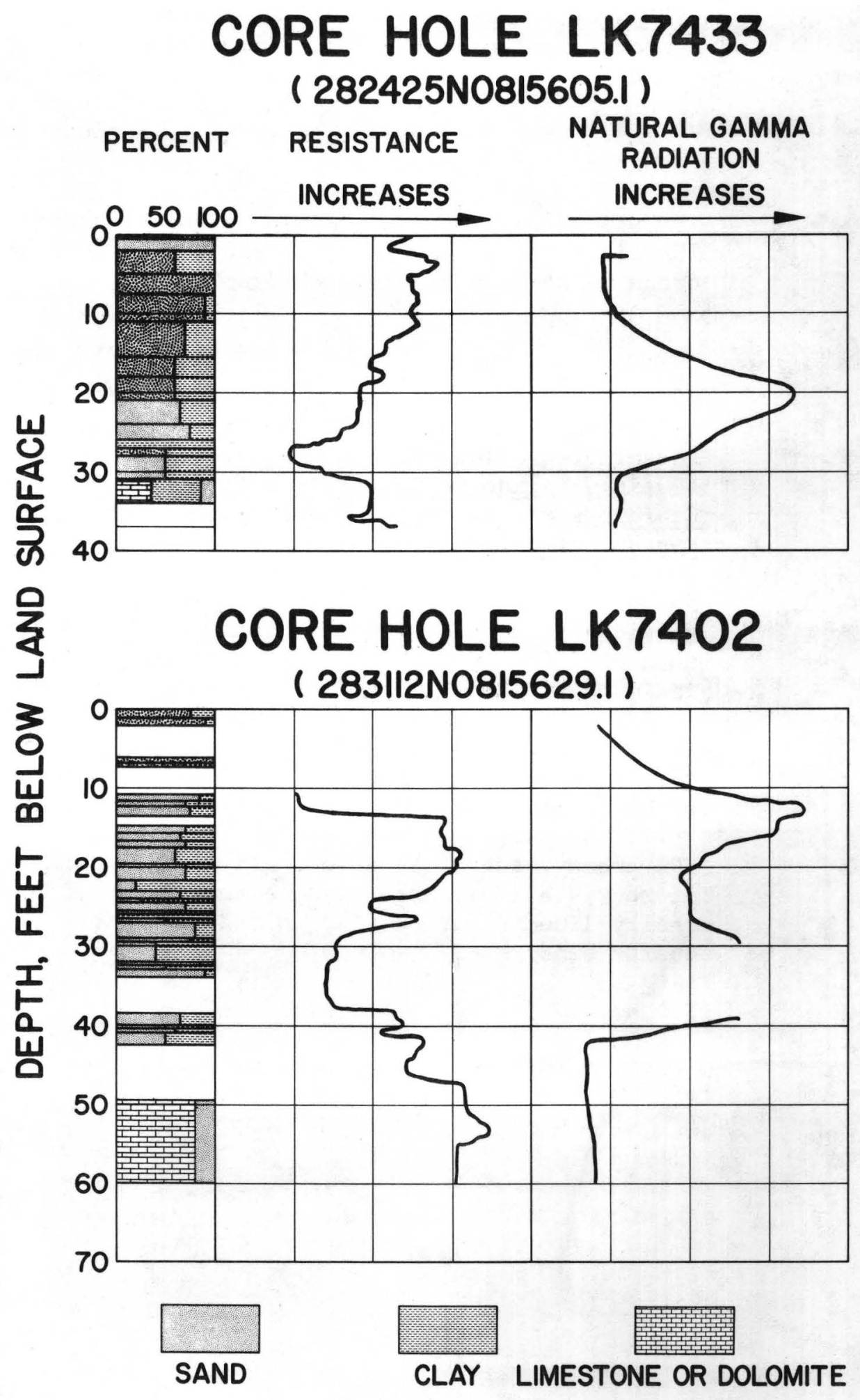


LK7403

Lake County $\quad 283404$ N0815317.1

DEPTH INTERVAL (feet)

$0.0-5.0$

$5 \cdot 0-6 \cdot 0$

$6.0-7.0$

$7.0-8.0$

$8 \cdot 0-13.0$

$13.0-18.5$

$18.5-22.0$

\section{LITHOLOGY}

\section{Post Miocene Rocks}

90\% 1ight tan, stained, medium-grained, fairly well sorted, sub-angular to sub-rounded unconsolidated sand; $10 \%$ coarse-to very coarse-grained sand.

$55 \%$ white, clear to frosted, fine-to medium-grained, angular to sub-rounded sand; $40 \%$ white, orange, and du11 ye11ow mottled, indurated, crumb1y clay matrix; $5 \%$ coarse-to very coarse-grained sand.

$60 \%$ pink and white, clear to stained, fine-to very coarse-grained, angular to rounded sand; $35 \%$ white, pink, orange, dull yellow and very pale green banded, indurated clay matrix; $5 \%$ coarse-to very coarse-grained sand.

$35 \%$ white, pink, and tan mottled, indurated, crumbly clay matrix; $30 \%$ 1ight gray, frosted, coarse-to very coarse-grained, fairly well sorted, rounded to well rounded sand; $30 \%$ fine to medium-grained sand; $5 \%$ sma11 pebbles.

$65 \%$ white, clear, fine-grained, angular, well sorted sand; $35 \%$ off-white, indurated, well consolidated clay matrix with some orange and tan streaking and mottling; trace of heavy minerals and fine to medium muscovite flakes; occasional coarse-to very coarse-grained sand.

$65 \%$ light gray, clear, frosted, fine-to medium-grained, fairly we11 sorted, sub-rounded sand; $30 \%$ light gray and tan mottled, indurated clay matrix; $5 \%$ coarsegrained sand.

$65 \%$ light gray, clear to frosted, medium-grained, we11 sorted, sub-rounded sand; $30 \%$ white, soft, crumbly clay matrix; 5\% coarse-grained sand; trace of heavy minerals. 
$22.0-28.5$

$28.5-34.0$

$34.0-40.0$

$40.0-42.0$

$42 \cdot 0-45 \cdot 0$

$45 \cdot 0-49 \cdot 0$

$49.0-51.0$

$51.0-52.0$

$52.0-55.0$

$55.0-65.0$

$65.0-70.0$
$60 \%$ white, clear, fine-to medium-grained, subangular sand; $40 \%$ very light tan, indurated clay matrix.

$70 \%$ white, clear, fine grained, well sorted, angular sand; $30 \%$ white, soft clay matrix; scattered bands of coarse-grained sand.

$80 \%$ white to light gxay, clear to frosted, medium-to fine-grained, sub-angular to rounded sand; $20 \%$ white and light tan mottled, soft clay matrix; trace of heavy minerals.

$85 \%$ sand, as above; $15 \%$ soft, white and medium tan mottled, poorly consolidated clay matrix; trace of heavy minerals.

$70 \%$ sand, as 34.0-40.0 interval; $30 \%$ very pale green with minor white mottling, indurated clay matrix; trace of heavy minerals.

$60 \%$ light gray, clear to frosted, medium-grained, we11 sorted, sub-rounded sand; 40\% light green, indurated clay matrix with pockets of white, soft, powdery clay; trace of heavy minerals.

Sand, as above; $40 \%$ 1ight gray and dul1 orange, mottled, soft, waxy clay matrix.

$65 \%$ light gray, clear to frosted, fine-to medium-grained, angular to sub-rounded sand; $30 \%$ light tan, indurated clay matrix; $5 \%$ coarse to very coarse grained sand.

$96 \%$ green, soft, waxy clay matrix; $3 \%$ white, clear, fine-grained, angular, well sorted sand; $1 \%$ small fossiliferous material and a few fragments of lignite; minor orange mottling in last 0.1 foot and also a thin band of sand in last 0.1 foot.

97\% light, bluish green, soft, waxy, clay matrix with minor light to medium brown mottling and streaking; $3 \%$ sand and small fossiliferous material, as above.

$50 \%$ light gray, clear to frosted, fine-to medium-grained, angular to sub-rounded sand; $50 \%$ light green, soft, waxy clay matrix, with minor pockets of sand and offwhite microcrystalline, silicified limestone; trace of heavy minerals. 
$50 \%$ light gray, clear to frosted, medium-grained, fairly well sorted, sub-angular to sub-rounded sand; $35 \%$ light green and light brown mottled soft, clay matrix with black organic matter and minor mottling by very light tan, soft, waxy clay; $5 \%$ fine to very coarse brown phosphate nodules; $5 \%$ coarse-to very coarse-grained sand; $5 \%$ pisolitic silica and off-white microcrystalline, silicified limestone.

\section{Rocks of Miocene Age}

$71.0-72.0$

$72.0-72.5$

$72.5-74.0$

$74.0-76.0$

$76.0-83.0$
Light tan and dark brown mottled, soft, waxy, well consolidated clay.

Sand as 70.0-71.0 interval, without organic matter.

$55 \%$ sand; $30 \%$ tan and brown mottled, indurated crumbly clay matrix; $5 \%$ phosphate; $5 \%$ coarse-to very coarse-grained sand; $5 \%$ silica and limestone as 70.0-71.0 interval.

$65 \%$ light tan and dark brown mottled, soft, waxy clay; $35 \%$ sand, as $70.0-71.0$ interval.

\section{Rocks of Eocene Age(?)}

No sample, lost circulation. 


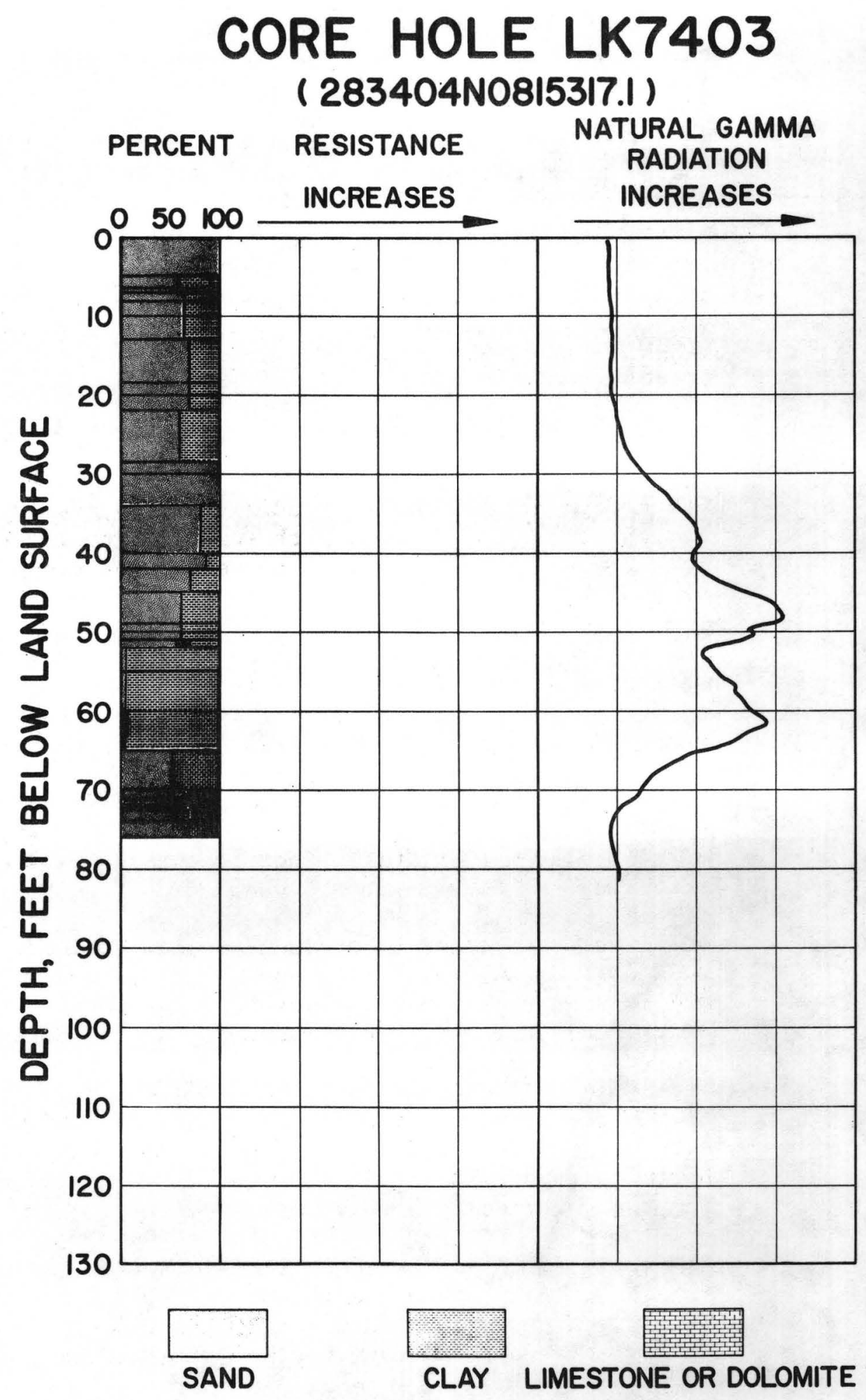


LK7 404

Lake County

283201N0815450.3

DEPTH INTERVAL (feet)

$0.0-1.0$

$1.0-4.0$

$4.0-7.0$

$7.0-11.0$

$11.0-16.0$

$16.0-17.0$

$17.0-17.5$

$17.5-20.5$
LITHOLOGY

\section{Post Miocene Rocks}

Light brown to light gray, clear to stained, mediumgrained, fairly well sorted, sub-rounded sand, with trace of brown and gray mottled clay.

$75 \%$ sand, as above; $25 \%$ dark brown, soft, crumbly clay matrix.

$70 \%$ medium brown, stained, medium-grained, fairly wel1 sorted, sub-rounded sand, with scattered coarse to very coarse grains; $30 \%$ very dark to very light brown mottled, very poorly consolidated clay matrix.

$60 \%$ tan, clear to stained, medium grained, fairly we 11 sorted, sub-rounded sand; $30 \%$ light tan and light brown mottled, indurated clay matrix; 5\% coarse-grained sand; $5 \%$ fine-grained sand; trace of heavy minerals.

$65 \%$ white, clear to frosted, medium-grained, fairly well sorted, sub-angular to sub-rounded sand; $30 \% \mathrm{tan}$, indurated clay matrix, with minor streaks of dark brown soft clay; $5 \%$ coarse-grained sand.

$60 \%$ light tan, clear to stained, medium-grained, fairly well sorted, sub-angular to sub-rounded sand; $35 \%$ tan and light brown mottled, indurated clay matrix, with minor, very dark brown clay mottling and streaking; $5 \%$ coarse-grained sand.

$50 \%$ white, frosted, fine-to medium-grained, angular to sub-rounded sand; $50 \%$ very light tan, and very light brown mottled, indurated clay matrix, with minor streaking and mottling by a very dark brown clay.

$55 \%$ very light tan, stained, fine-to medium-grained, angular to sub-rounded sand; $40 \%$ very light tan and very light brown mottled and streaked indurated clay matrix; 5\% coarse-to very coarse-grained sand. 
$20.5-23.5$

$23 \cdot 5-27.0$

$27.0-30.5$

$30.5-31.0$

$31.0-35.0$

$35.0-36.5$

$36.5-39.0$

$39.0-40.0$

$40.0-44.0$

$44.0-46.0$

$46.0-46.5$

$46.5-47.0$

$47,0-48.0$
$50 \%$ very light tan, stained, medium-to very-coarse grained, sub-rounded to we11-rounded sand; $50 \%$ tan and light brown banded and mottled, indurated clay matrix with minor mottling and streaking by dark brown clay.

$60 \%$ light, clear to frosted, fine-to very coarse-grained, angular to well-rounded sand; $40 \%$ off-white, very light tan mottled, indurated clay matrix; trace of heavy minerals.

$65 \%$ sand, as above; $35 \%$ light brown, soft clay matrix; trace of heavy minerals.

$65 \%$ sand, as $23.5-27.0$ interval; $35 \%$ tan, indurated clay matrix; trace of heavy minerals.

$70 \%$ white, clear to frosted, medium-to fine-grained, angular to sub-rounded sand; $25 \%$ light to medium tan, soft clay matrix; $5 \%$ coarse-to very coarse-grained sand; trace of heavy minerals.

No sample.

$60 \%$ white, clear to frosted, medium-to fine-grained, angular to sub-rounded sand; $40 \%$ light tan, soft clay matrix; trace of heavy minerals.

$70 \%$ sand, as above; $30 \%$ tan, soft clay matrix; trace of heavy minerals.

$60 \%$ white, clear to frosted, medium-to fine-grained, angular to sub-rounded sand; $40 \%$ light tan, soft, clay matrix; trace of heavy minerals.

No sample.

$65 \%$ white, clear to frosted, fine-grained, sub-angular, fairly well sorted sand; $30 \%$ very light tan, indurated, crumbly, clay matrix; $5 \%$ medium-grained sand.

$70 \%$ white, clear to frosted, fine-grained, well sorted, sub-angular sand; $30 \%$ white and light tan mottled, indurated clay matrix.

$50 \%$ light brown, soft, waxy clay matrix; $30 \%$ sand, as 46.5-47.0 interval; $20 \%$ white, microcrystalline, indurated, porous, silicified limestone. 
$48.0-48.5$

$48.5-49.5$

$49 \cdot 5-49.7$

$49.7-50.5$

$50.5-51.5$

$51.5-54.0$

$54.0-58.0$

$58 \cdot 0-59 \cdot 0$

$59.0-59.5$

$59 \cdot 5-61.0$
$65 \%$ white, clear to frosted, fine-to medium-grained, angular to sub-rounded sand; $35 \%$ tan, soft, clay matrix; interbedding by medium brown, soft, waxy clay; trace of heavy minerals.

$95 \%$ medium brown, soft, waxy, clay matrix; $5 \%$ sand as above.

$70 \%$ brown with green tint, soft clay; $25 \%$ light brown, soft, clay matrix, with minor mottling; $5 \%$ sand, as 48.0-48.5 interval.

$60 \%$ sand as 48.0-48.5 interval; $40 \%$ medium brown, soft clay, mottled with medium brown soft, waxy clay; trace of fine grained rose quartz; trace of white microcrystalline, indurated, porous, silicified limestone.

$60 \%$ sand, as 48.0-48.5 interval; $40 \%$ light brown, soft clay matrix, banded with pure, medium brown, soft, waxy clay; trace of heavy minerals; trace of silicified limestone, as 49.7-50.5 interval.

$65 \%$ sand, as 48.0-48.5 interva1; $35 \%$ tan, soft, clay matrix, with dark brown mottling; contains pockets and bands of light grayish brown, pure, waxy, clay; trace of silicified limestone, as 49.7-50.5 interval.

$70 \%$ medium brown, bluish green, light brown, soft clay, with dark gray mottling; $30 \%$ sand, as $48.0-48.5$ interval; pockets and bands of clay; trace of heavy minerals.

$60 \%$ medium brown to dark gray banded, soft, clay matrix; 40\% light gray, clear to frosted, mediumgrained, fairly well sorted, sub-angular to subrounded sand; trace of pisolitic silica.

$60 \%$ light gray, clear to stained, medium-grained, fairly well sorted, sub-angular to sub-rounded sand; $40 \%$ mediuin brown, soft, clay matrix, mottled with black, soft clay.

\section{Rocks of Miocene Age}

$50 \%$ buff and light gray, microcrystalline, hard, tight to porous, silicified limestone fragments with relic fossil material; $40 \%$ black and medium brown mottled, soft, crumbly, clay matrix; $8 \%$ light gray, clear to frosted, medium-grained, fairly well sorted, sub-angular to subrounded sand; $2 \%$ fine-grained sand. 
Rocks of Eocene Age(?)

61.0-72.4 Lost circulation; no sample. 


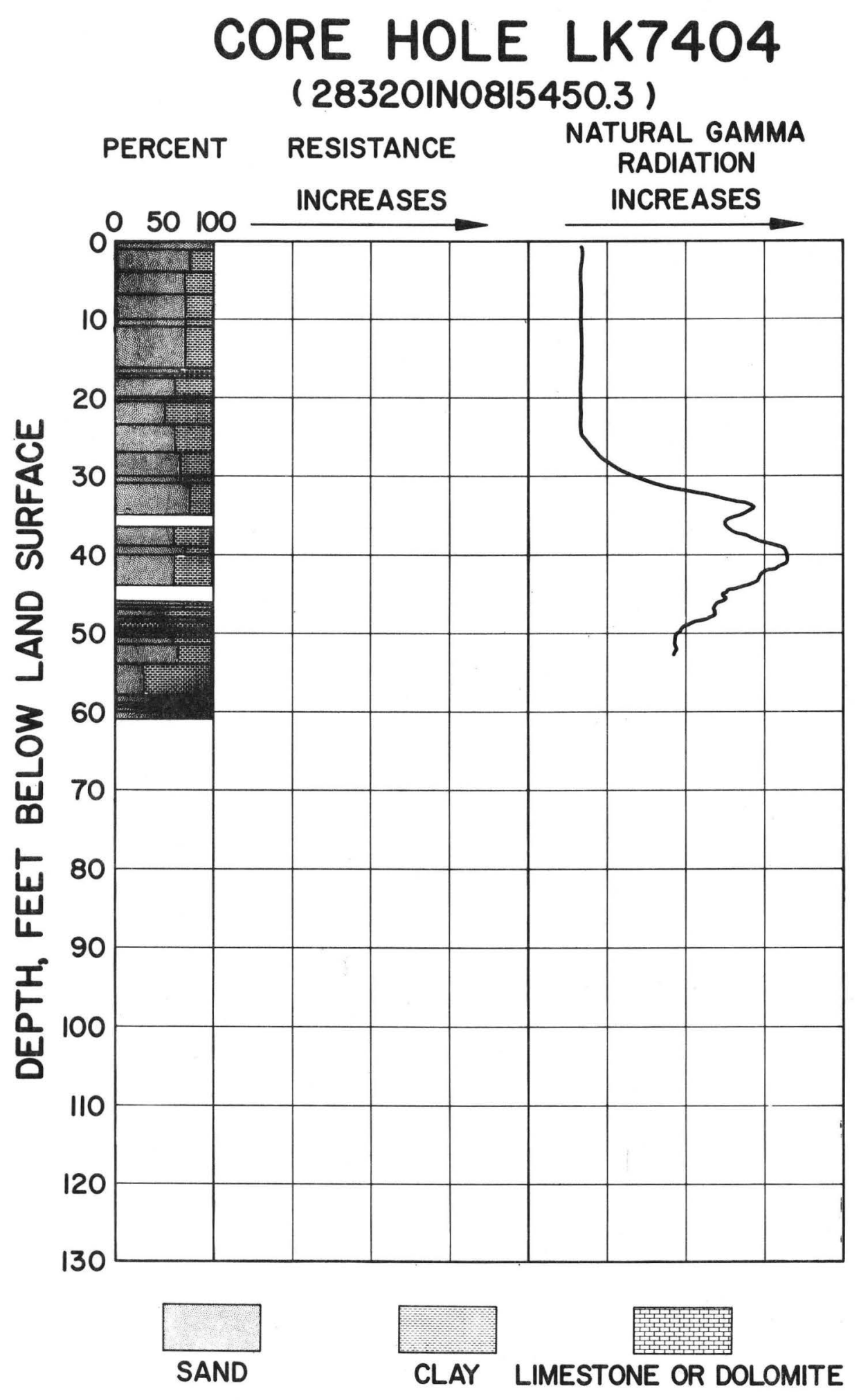


Lake County 283122N0815226.1

DEPTH INTERVAL (feet)

$4.0-15.0$

$15 \cdot 0-16.0$

$16.0-16.5$

$16.5-18.0$

$18.0-20.0$

$20.0-32.5$

$32.5-37.0$

$37.0-43.0$

$43.0-47.0$

$47.0-49.0$

$49.0-53.0$

\section{LITHOLOGY}

\section{Post Miocene Rocks}

95\% 1ight gray, clear to stained, medium-grained, fairly we11 sorted, sub-rounded sand; $5 \%$ fine and coarse-grained sand.

95\% tan, stained, medium-grained, fairly well sorted, subrounded sand; $5 \%$ fine and coarse-grained sand.

No sample.

$70 \%$ light gray, soft, waxy clay matrix; $30 \%$ white, frosted, medium-to very coarse-grained, rounded sand.

$50 \%$ light gray, soft, waxy clay matrix; $50 \%$ sand, as above.

$60 \%$ light gray, frosted, coarse-to very coarse-grained, rounded sand; $30 \%$ off-white, indurated, fairly well consolidated clay matrix; $10 \%$ medium grained sand.

No sample.

$50 \%$ white, clear to frosted, medium-grained, fairly wel1 sorted, angular sand; $40 \%$ off-white to $t a n$, indurated clay matrix; $10 \%$ medium-to very coarse-grained sand; trace of fine to medium muscovite.

No sample.

$65 \%$ white, clear to frosted, fine-grained, angular, fairly well sorted sand; $35 \%$ very light tan to offwhite, indurated, crumbly, clay matrix; trace of heavy minerals and fine to medium muscovite.

No sample.

$60 \%$ sand as above; $35 \%$ off-white, indurated, crumbly, clay matrix; $5 \%$ medium grained sand; trace of fine-to medium-grained muscovite.

No sample. 
$53.0-53.5$

$80 \%$ 1ight gray, clear, medium-grained, rounded, wel1 sorted sand; $20 \%$ white and light green, mottled, indurated clay matrix; trace of heavy minerals.

\section{Rocks of Miocene Age}

$53.5-57.5$

$70 \%$ blue, light brown, and light green, mottled, indurated clay matrix; $30 \%$ white, clear, fine-to medium-grained, angular to sub-rounded sand.

$57.5-63.1$

No sample.

\section{Rocks of Eocene Age(?)}

$63.1-84.1$

Lost circulation; could not be re-established;

fragments of limestone on end of drill bit. 


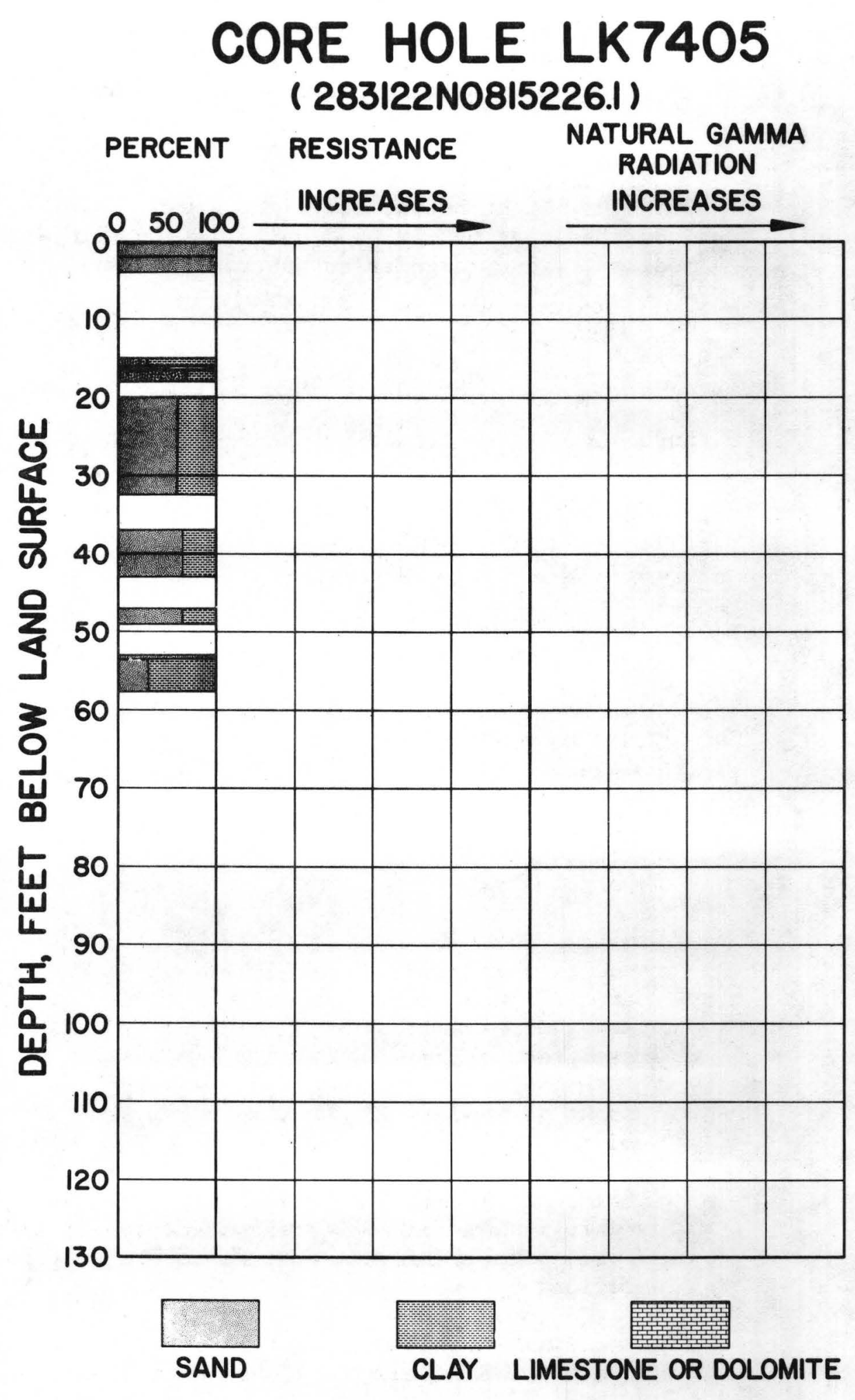


Lake County $\quad 283207$ N0814921.1

DEPTH INTERVAL (feet)

$0.0-4.0$

$4.0-9.5$

$9 \cdot 5-17.0$

$17.0-22.5$

$22.5-27.0$

$27.0-29.0$

$29.0-30.0$

$30.0-33.2$

$33.2-36.5$

$36.5-37.5$

$37.5-38.0$

\section{LITHOLOGY}

\section{Post Miocene Rocks}

Tan, stained, medium-to fine-grained, angular to subrounded quartz sand.

$80 \%$ dull yellow, stained, fine-to medium-grained, angular to sub-rounded quartz sand; $20 \%$ bright orange, indurated, fairly well consolidated, clay matrix.

White, clear to frosted, fine-to medium-grained, angular to sub-rounded quartz sand; trace of heavy minerals.

White, frosted, medium-to very coarse-grained, subrounded to we11 rounded quartz sand with pink tint.

$90 \%$ white, frosted, coarse-to very coarse-grained, rounded to we11 rounded quartz sand; $10 \%$ pink and light tan, mottled, soft clay matrix.

$50 \%$ white, frosted, fine-to very coarse-grained, angular to sub-rounded sand; $50 \%$ medium brown, soft clay matrix.

$60 \%$ white, clear to frosted, fine-grained, fairly well sorted, angular sand; $35 \%$ dul1 red and white banded ( $1 / 8$ to $1 / 2$-inch) soft clay matrix; $5 \%$ medium-to very coarse-grained sand; trace of fine to medium muscovite flakes; trace of heavy minerals.

$60 \%$ sand, as above; $40 \%$ clay, as above, but darker red in color.

$70 \%$ sand, as 29.0-30.0 interva1; $30 \%$ pink, indurated clay matrix with numerous small white specks and minor dull yellow mottling; trace of muscovite and heavy minerals as above.

$65 \%$ sand, as $29.0-30.0$ interval; $35 \%$ clay, as $33.2-36.5$ interval; trace of muscovite and heavy minerals.

$65 \%$ sand, as 29.0-30.0 interval; $35 \%$ bright orange, soft clay matrix with numerous white specks and some white, thin bands; trace of heavy minerals and muscovite. 
$38.0-40.0$

$40.0-42.5$

$42.5-43.0$

$43.0-43.5$

$43.5-44.5$

$44.5-45.7$

$45.7-47.0$

$47.0-48.5$

$48.5-50.0$

$50.0-51.0$

$51.0-53.0$

$53.0-77.0$
$80 \%$ sand, as $29.0-30.0$ interval; $20 \%$ light orange, indurated clay matrix, with thin light bands; trace of heavy minerals and muscovite.

$80 \%$ white and yellow, clear to stained, fine-to mediumgrained, angular to sub-rounded sand; $20 \%$ dull yellow, indurated clay matrix with minor light brown and white mottling and banding; trace of heavy minerals.

$55 \%$ white, clear and yellow, stained, medium-grained, fairly well sorted, sub-angular sand; $25 \%$ fine-grained sand; $20 \%$ clay, as $40.0-42.5$ interval; trace of heavy minerals.

$70 \%$ sand, as above; $30 \%$ very pale green, indurated clay matrix with some white and medium brown mottling and banding.

$65 \%$ sand, as $42.5-43.0$ interva1; $20 \%$ white, light tan, medium brown mottled and banded, indurated crumbly clay matrix; $15 \%$ medium-grained sand.

\section{Rocks of Miocene Age}

$85 \%$ sand, as $42.5-43.0$ interva1; $15 \%$ off-white, indurated, crumbly clay matrix with minor light brown mottling; trace of heavy minerals.

$75 \%$ sand, as $42.5-43.0$ interva1; $20 \%$ white, light brown, and buff mottled, indurated, crumbly clay matrix with black organic streaks; $5 \%$ white, pisolitic silica; trace of heavy minerals.

99\% medium grained, indurated, blocky, waxy clay matrix; $1 \%$ white, clear, fine-to medium-grained, angular sand.

99\% off-white, indurated, well consolidated clay matrix; $1 \%$ white, clear, fine-to medium-grained, angular sand.

$45 \%$ white to pink to tan phosphate nodules; $40 \%$ light buff, indurated clay matrix; $15 \%$ white, clear, fine-to medium-grained, angular quartz sand.

$80 \%$ very light gray with tan tint, indurated porous silt; $20 \%$ phosphate as above; trace of white sand, as above.

No sample; lost circulation at 59 feet. 
Rocks of Eocene Age(?)

$77.0-81.0$

No sample; circulation could not be re-established;

top of interval based on natural gamma 1 og. 


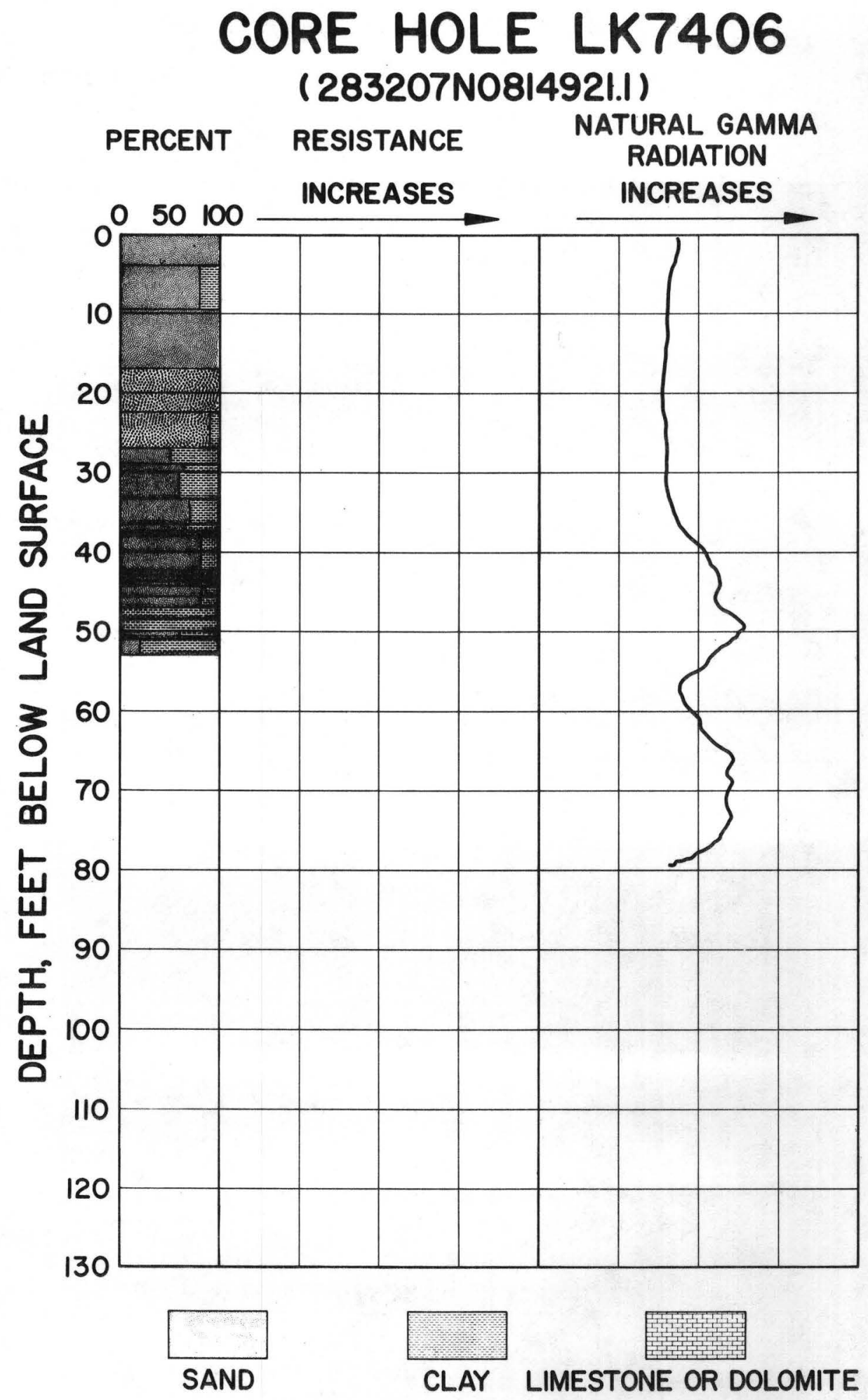


LK7407

Lake County $\quad 283054$ N0814938.1

DEPTH INTERVAL (feet)

0.0 .1 .5

$1.5-3.5$

$3 \cdot 5-6.0$

$6.0-8.0$

$8.0-9.0$

$9.0-12.0$

$12 \cdot 0-15.5$

$15.5-16.5$

$16.5-17.5$

$17.5-18 \cdot 0$

$18.0-23.0$

\section{LITHOLOGY}

\section{Post Miocene Rocks}

Light gray and brown, clear and stained, medium-to coarse-grained, sub-rounded sand.

90\% dark brown, stained, medium-grained, fairly wel1 sorted, sub-rounded sand; $10 \%$ dark brown, soft, crumbly clay matrix.

No sample.

$60 \%$ light gray, frosted, very coarse-to coarse-grained, fairly well sorted, rounded sand; $40 \%$ tan, soft, clay matrix.

$50 \%$ light gray, frosted, medium-grained, fairly wel1 sorted, sub-rounded sand; $50 \%$ very light and medium tan, banded, indurated, micaceous clay matrix.

$50 \%$ white, clear to frosted, fine-to medium-grained, angular to sub-angular sand; $50 \%$ clay, as above; trace of muscovite flakes.

$60 \%$ light gray, frosted, very coarse-to coarse-grained, fairly well sorted, rounded sand; $40 \%$ light brown, indurated, fairly we11 consolidated clay matrix; trace of muscovite flakes.

$55 \%$ white, clear, fine-grained, we11 sorted, angular sand; $40 \%$ off white, indurated, crumbly clay matrix; $5 \%$ medium muscovite flakes.

$50 \%$ very light tan, soft, crumbly clay matrix; $45 \%$ white, clear, fine-to medium-grained, angular to subrounded sand; $5 \%$ medium to coarse muscovite flakes.

95\% white to light gray, clear to frosted, very coarsean to medium grained-sand; $5 \%$ very light tan to creamy, indurated, crumbly clay matrix.

$60 \%$ white, clear, fine grained, we11 sorted, angular sand; $35 \%$ very light tan, indurated, crumbly clay matrix; $5 \%$ coarsemto very coarse-grained sand; trace of heavy minerals. 
$23.0-26.5$

$26.5-28.5$

$28.5-41.0$

$41.0-41.5$

$41.5-42.2$

$42.2-42.5$

$42 \cdot 5-44.5$

$44.5-46.0$

$46.0-48.0$

$48.0-49.5$

$49.5-51.0$
$55 \%$ light gray, frosted, very coarse-grained, we11 rounded, fairly wel1 sorted sand; $25 \%$ tan, soft, poorly consolidated, crumbly clay matrix; 20\% finegrained sand.

$75 \%$ clear, fine-grained, angular, well sorted sand; $20 \%$ light tan, soft clay matrix; $5 \%$ very coarse to coarse-grained sand.

$75 \%$ white, clear, fine-to medium-grained, angular to sub-angular sand; $20 \%$ light tan, soft clay matrix; $5 \%$ very coarse-to coarse-grained sand; trace of heavy minerals.

$65 \%$ white to light gray, clear to frosted, coarse-to very coarse-grained, we11 sorted, we 11 rounded sand; $25 \%$ medium brown, soft clay matrix; $10 \%$ fine-to medium grained-sand; trace of heavy minerals.

$65 \%$ white to light gray, clear to frosted, mediumgrained, fairly well sorted, sub-angular sand; $35 \%$ white and light brown mottled, soft clay matrix.

\section{Rocks of Miocene Age}

$55 \%$ sand, as $41.5-42.2$ interval; $45 \%$ brown and light tan mottled, soft clay matrix; trace of fossil fragments.

$50 \%$ sand, as 41.5-42.2 interval; $50 \%$ medium brown, soft clay matrix, mottled with very light tan, soft, wel1 consolidated clay; trace of fossil fragments; several pieces of fine-to medium-grained, clear, sub-angular, rose quartz.

No sample.

$40 \%$ dark brown and medium gray mottled, soft clay matrix; 35\% light gray, clear to frosted, fine-to medium-grained, angular, sub-rounded sand; $15 \%$ fine to medium black phosphate nodules; $10 \%$ pisolitic silica; trace of rose quartz.

$98 \%$ very light brown, soft, waxy clay with minor mottling by dark brown, soft waxy clay; $2 \%$ sand and phosphate, as above.

$50 \%$ dark gray and light tan mottled, soft, waxy clay matrix; $35 \%$ multicolor, fine to very coarse phosphate fragments and nodules; $15 \%$ white, clear, medium-grained well sorted, sub-rounded sand. 
$51.0-51.5$

$51.5-53.0$

$53.0-53.2$

$53.2-54.0$

$54.0-55.2$

$55.2-56.5$

$56.5-57.5$

$57.5-58.5$

$58.5-58.7$

$58.7-60.5$

$60.5-62.5$
$60 \%$ greenish gray, soft clay matrix; $25 \%$ white, clear, medium-to fine-grained, angular to sub-rounded sand; $15 \%$ fine to coarse, multicolored phosphate fragments and nodules.

95\% medium brown, soft, waxy clay matrix; 4\% 1ight gray, clear to frosted, medium-to coarse-grained, subrounded sand; $1 \%$ medium to very porous, multicolored phosphate fragments and nodules.

$40 \%$ medium brown and medium gray, mottled, soft clay; $35 \%$ white, clear, fine-to medium-grained, angular to sub-rounded sand; $25 \%$ fine to very coarse black phosphate nodules.

$40 \%$ fine to very coarse, black to brown, phosphatized fossil material and phosphate nodules; 35\% light tan, indurated clay matrix; $25 \%$ sand, as above.

$55 \%$ medium, greenish gray, soft clay matrix; $40 \%$ sand as $53.0-53.2$ interval; $5 \%$ phosphate as $53 / 2-54.0$ interval.

No sample.

$65 \%$ medium, greenish gray and light brown mottled, soft clay matrix; $20 \%$ fine to very coarse multicolored phosphate; $15 \%$ white, clear to frosted, medium-grained, fairly well sorted, sub-angular to sub-rounded sand.

$50 \%$ white to light gray, clear to frosted, medium-to coarse-grained, sub-rounded to rounded sand; $35 \%$ clay, as 56.5-57.5 interval; 15\% multicolored medium to very coarse phosphate.

$55 \%$ white, clear, fine-to medium-grained, sub-angular to sub-rounded sand; $35 \%$ light brown, soft clay; $10 \%$ multicolored, fine to very coarse phosphate.

$65 \%$ dark bluish gray, medium gray, and brownish gray mottled, soft, waxy clay matrix; $30 \%$ sand, as above; $5 \%$ phosphate, as above.

$60 \%$ 1ight and medium gray mottled, soft, silky clay matrix; $20 \%$ phosphate as 58.5 to 58.7 interval; $20 \%$ sand as 58.5-58.7 interval. 
$62 \cdot 5-65.0$

$65.0-69.5$

$69.5-70.5$

$70.5-75.0$

$75.0-90.9$
$50 \%$ fragments of creamy, very fine crystalline, porous, indurated, well consolidated dolomite; $40 \%$ sand, as 58.5-58.7 interva1; $10 \%$ phosphate as 58.558.7 interva1.

$65 \%$ medium gray, indurated, well consolidated, porous, very fine crystalline dolomite; $35 \%$ white, clear, finegrained, well sorted angular sand; trace of black to brown, fine to very coarse phosphate nodules; several large chunks of dark gray and medium brown mottled silicified limestone.

\section{Rocks of Eocene Age}

$50 \%$ very large foraminifera; $35 \%$ medium brown and white mottled, indurated, poorly consolidated, crumbly clay matrix; $15 \%$ clear to frosted, fine-to coarse-grained sand, contains Lepidocyclina ocalana floridana (Cushman), and Camerina sp.

No sample.

$60 \%$ creamy, microcrystalline, hard porous linestome, contains $30 \%$ large to small fossils and $10 \%$ fine-to coarse-grained sand; highly weathered. 


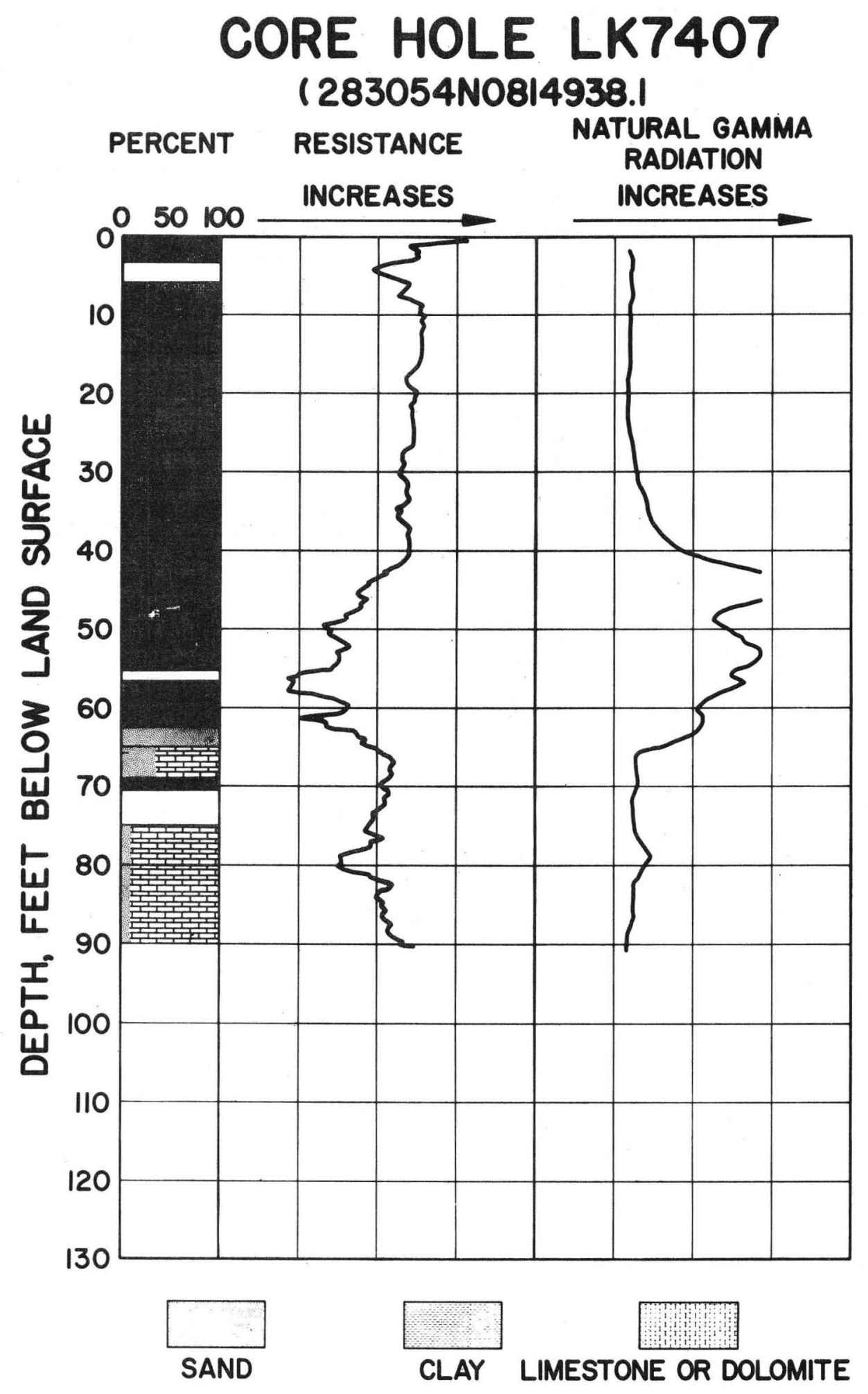


LK7408

Lake County $\quad 283041 N 0814700.01$

DEPTH INTERVAL

(feet)

$0.0-4.0$

$4 \cdot 0-10.5$

$10.5-12.0$

$12.0-17.0$

$17.0-21.0$

$21.0-24.0$

$24.0-26.0$

$26.0-28.5$

$28.5-30.5$

$30.5-31.0$

\section{LITHOLOGY}

\section{Post Miocene Rocks}

Tan, stained, medium-grained, poorly sorted, subrounded quartz sand; trace of heavy minerals.

$50 \%$ white, clear to orange stained, medium-grained, fairly well sorted, sub-rounded quartz sand; $50 \%$ orange, soft clay matrix with minor yellow mottling.

$80 \%$ white to tan, clear to frosted, coarse-to mediumgrained, fairly well sorted, sub-rounded quartz sand; $20 \%$ light to dark orange, soft clay matrix with slight tan tint.

$75 \%$ white, clear to frosted, very-coarse to coarsegrained, fairly well sorted rounded quartz sand, with abundant medium grained sand; $25 \%$ tan and orange mottled, soft clay matrix.

$75 \%$ sand, as above; $25 \%$ white and orange mottled, soft clay matrix.

$85 \%$ sand, as $12.0-17.0$ interval; $15 \%$ clay as $17.0-21.0$ interval.

$75 \%$ white frosted, very-coarse to medium-grained, sub-rounded to rounded quartz sand; $25 \%$ pink to white, soft clay matrix with $1 / 8$ to $1 / 4-i n c h$ bands of hard clay.

$80 \%$ white to light gray, frosted, very coarse-grained, poorly sorted, rounded quartz sand; $20 \%$ white and orange mottled, soft clay matrix; a 1-inch band of yellow clay at 27.2 feet.

$80 \%$ white to light gray, frosted, very coarse-grained, poorly sorted, rounded quartz sand; $20 \%$ pink and white mottled, soft clay matrix.

$75 \%$ sand, as above; $25 \%$ white and dull yellow banded, soft clay matrix. 
$31.0-32.0$

$32.0-35.0$

$35.0-43.0$

$43.0-45.5$

$45.5-56.0$

$56.0-59.0$

$59.0-61.5$

$61.5-62.5$

$62 \cdot 5-63.5$

$63.5-64.0$

$64.0-69.0$

$69.0-69.5$

$69.5-70.0$
$80 \%$ white, frosted, very coarse-grained, we11 sorted, well rounded quartz sand; $20 \%$ white and dull yellow mottled, soft, poorly consolidated clay matrix. Some orange mottling in lower 0.2 feet.

$45 \%$ fine grained, white, frosted, angular, we11 sorted quartz sand; $40 \%$ sand as 31.0 to 32.0

interva1; $15 \%$ white, du11 yellow and pink mottled, soft clay matrix.

No sample.

$75 \%$ white, clear to frosted, fine-grained, well sorted, sub-angular quartz sand with scattered orange grained sand; $25 \%$ dull yellow, tan, orange, brown and pink mottled, soft clay matrix.

No sample.

$50 \%$ sand, as $43.0-45.5$ interval; $35 \%$ brown, du 11 yellow and white mottled and banded, soft clay matrix; $15 \%$ coarse-grained sand.

$70 \%$ white, clear to frosted, fine-grained, very wel1 sorted angular quartz sand; $30 \%$ very thin alternating bands ( $1 / 32$ to 1/8-inch) of white, dull yellow and orange, soft clay matrix; trace of coarse-grained sand.

Sand as above, without coarse-grained sand; $30 \%$ clay as above, with banding less well defined.

$70 \%$ white to light brown, clear to stained, fine-to medium-grained, sub-angular quartz sand; 30\% light golden brown, soft clay matrix.

$70 \%$ clay matrix of alternating bands (1/32 to $1 / 8-$ inch) of dark brown and light greenish brown, soft, waxy clay; $30 \%$ sand, as above.

No sample.

\section{Rocks of Miocene Age}

Same as 63.5-64.0 interval.

$60 \%$ medium brown, soft clay; $40 \%$ white, clear, finegrained, well sorted, sub-angular quartz sand; trace of black organic material. 
$70.0-72.0$

$72.0-73.0$

$73.0-74.5$

$74.5-79.5$

$79.5-87.5$

$87.5-115.5$

$115.5-118.5$

$118.5-120.5$

120.5-176.0

$176.0-180.0$

$180.0-181.0$

$181.0-201.0$

$201.0-220.9$
$80 \%$ sand, as above; $20 \%$ very light, greenish gray, dul1 yellow and light tan mottled, soft clay matrix; trace of black organic material.

$85 \%$ sand, as $70.0-72.0 ; 15 \%$ light pink and white mottled, soft clay matrix; trace of organic material.

$55 \%$ sand, as 70.0-72.0 interval; 40\% 1ight greenish gray, soft clay matrix; $5 \%$ reddish brown, fine phosphate nodules and blades.

$50 \%$ sand, as $70.0-72.0$ interval; $45 \%$ very light greenish gray and du11 yellow mottled, indurated, well consolidated clay matrix; $5 \%$ phosphate as 73.0-74.5 interva1.

$60 \%$ matrix of light to medium brownish gray, soft, fairly well consolidated clay; $20 \%$ fine to large pebble size black phosphate nodules and reddish brown fine phosphate nodules and blades; $15 \%$ white, clear, fine-to medium-grained, fairly well sorted, sub-angular quartz sand; $5 \%$ large fragments of light gray to light brown microcrystalline, indurated, fairly tight dolomite; very large fragments (2-inch diameter) of light brown, microcrystalline, hard, tight, dense dolomite at base of interval.

No sample.

75\% 1ight greenish gray, soft, waxy clay matrix; $20 \% 1$ ight tan to pink to orange, fine to very coarse phosphate nodules; $5 \%$ white, fine-grained, fairly well sorted, angular quartz sand; lower 0.5 feet of interval is pure clay.

Large fragments of white microcrystalline, indurated, porous, vuggy, dolomitic limestone, abundant fossil molds and casts; trace of light gray, indurated, well consolidated, clay coating.

No sample.

Cavity.

No sample.

Cavity; circulation lost, could not be re-established. No sample. 


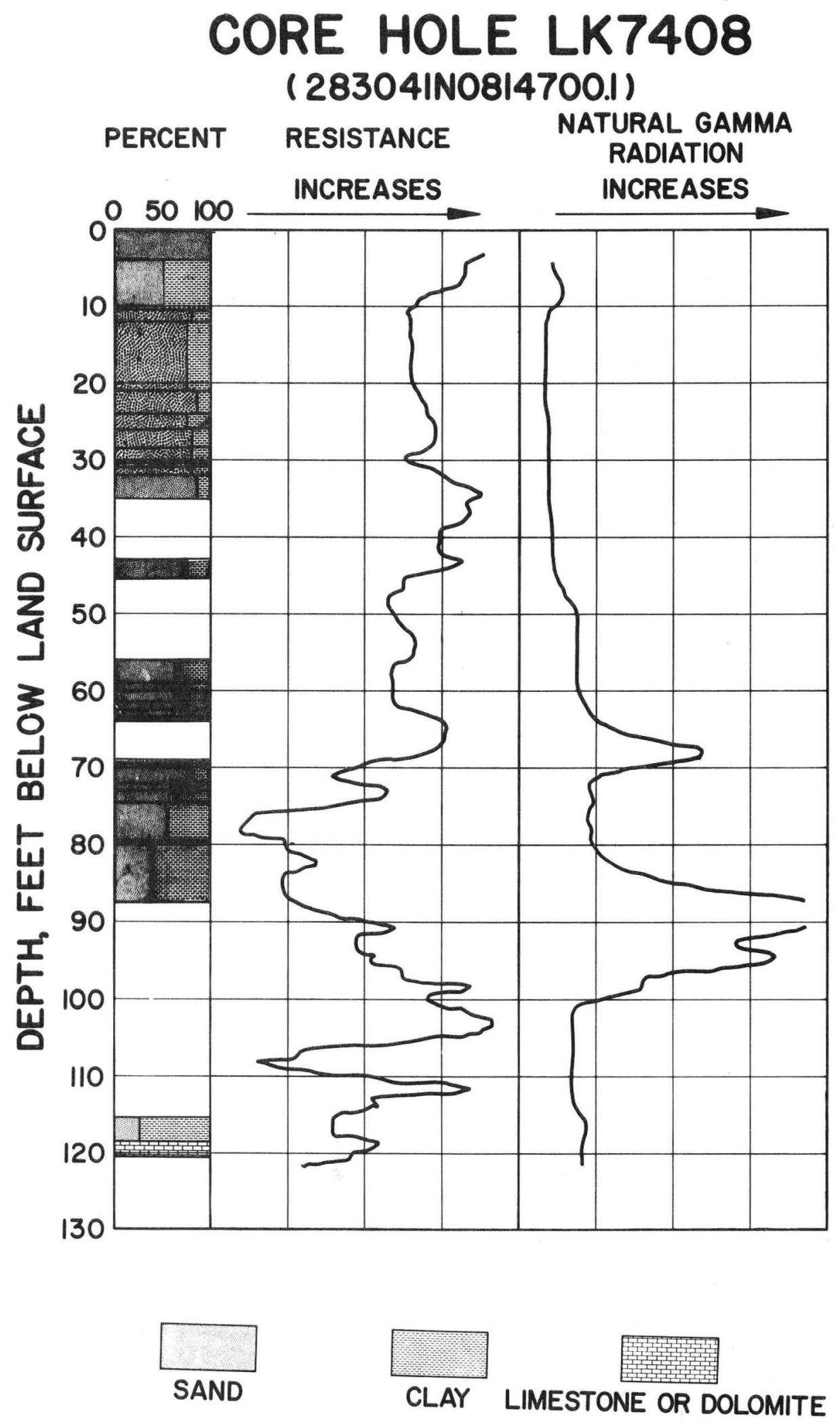



LK7409

Lake County 283024N0814533.1

DEPTH INTERVAL (feet)

$0.0-4.0$

$4 \cdot 0-14.0$

$14.0-26.0$

$26.0-28.5$

$28.5-29.5$

$29.5-30.5$

$30.5-34.0$

$34.0-42.0$

\section{LITHOLOGY}

\section{Post Miocene Rocks}

White and light brown, clear to stained, mediumgrained, fairly well sorted, sub-rounded quartz sand.

$75 \%$ white to light tan, clear to frosted, mediumgrained, fairly well sorted, sub-angular quartz sand; $25 \%$ tan, brown, and light gray mottled, soft clay matrix.

$80 \%$ white, clear to frosted, fine-to medium-grained, well sorted, sub-angular quartz sand; $20 \%$ very light brown, dark brown and white mottled, soft clay matrix; a decrease to $10 \%$ tan and white mottled, soft clay matrix in the lower 1 foot with corresponding increase in sand; trace of heavy minerals.

$85 \%$ white to yellow, clear to frosted, fine-to medium-grained, fairly well sorted, sub-angular quartz sand; $15 \%$ white, very light brown to tan mottled, indurated clay matrix; trace of heavy minerals.

$65 \%$ white, clear, fine-grained, fairly well sorted angular quartz sand; $30 \%$ very light gray, soft clay matrix; $5 \%$ heavy minerals; has tan and orange bands in lower 0.3 foot.

$70 \%$ light gray and light brown mottled, soft clay;

$30 \%$ white to yellow, clear, fine-grained, fairly well sorted angular quartz sand.

$50 \%$ white, clear to frosted, fine-grained, fairly well sorted angular quartz sand; $50 \%$ medium to dark brown mottled, soft, sticky clay matrix mottled with white, soft, sticky, waxy clay; trace of heavy minerals and multicolored, medium phosphate nodules.

$80 \%$ medium brown, light gray, dark brown mottled, soft clay matrix with much mottling by pure clays of the above mentioned colors; $15 \%$ white, clear to frosted, fine-to medium-grained, fairly well sorted, sub-angular quartz sand; $5 \%$ multicolored, fine to very coarse phosphate nodules and blades; trace of heavy minerals. 
$42.0-45.5$

$45.5-49.5$

$49 \cdot 5-58.0$

$58.0-59.5$

$59.5-64.5$

$64.5-66.0$

$66.0-69.0$

$69.0-72.0$

$72.0-73.0$

$73.0-74.0$

$74.0-75.5$

$75.5-104.0$
$50 \%$ orange, tan, light brown and white mottled soft clay matrix with pockets of pure light brown clay; $45 \%$ white, clear to frosted, fine-to medium-grained, well sorted, sub-angular to sub-rounded quartz sand; $5 \%$ red to orange, fine to medium phosphate blades and nodules.

$70 \%$ 1ight gray, white and tan mottled, soft clay matrix; $25 \%$ sand as above; $5 \%$ phosphate as above. Some small white microcrystalline, indurated, porous, dolomitic limestone fragments.

99\% very light gray, soft, well consolidated clay; $1 \%$ sand as 42.0-45.5 interva1; trace of phosphate.

Clay as above with very light green tint; trace of phosphate, sand as 42.0-45.5 interval.

99\% 1ight gray brown tinted, soft clay; $1 \%$ sand as 52.0-45.5 interval; trace of phosphate.

$70 \%$ medium bluish gray, indurated, clay matrix having pockets of sand as below in a matrix of $40 \%$ very light gray clay; $25 \%$ white, clear to frosted, finegrained, well sorted, angular, quartz sand; $5 \%$ multicolored, fine phosphate nodules and blades.

Same as 59.5-64.5 interval.

No sample.

Light greenish gray, indurated clay; trace of phosphate, sand as 42.0-45.5 interval.

$50 \%$ sand as $42.0-45.5$ interval; $50 \%$ medium bluish gray, indurated clay matrix, very thinly interbedded with very light gray indurated clay; trace of phosphate.

$50 \%$ very light tan, calcareous, indurated clay matrix; $40 \%$ white, clear to frosted, fine-to medium-grained, fairly well sorted, angular to sub-rounded, quartz sand; $10 \%$ red to brown to light tan, fine to coarse phosphate nodules and blades.

No sample. 


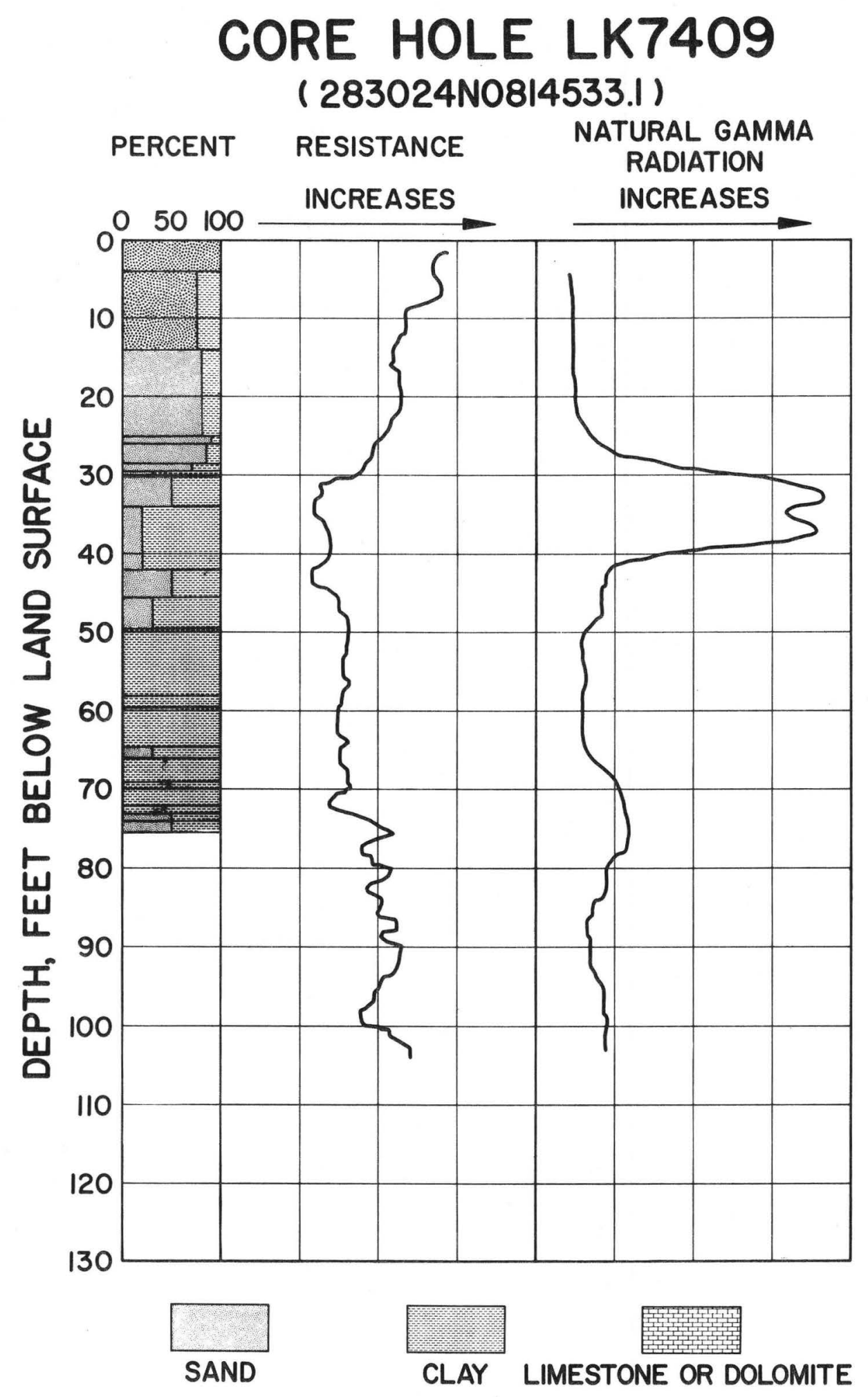


Lake County 282508N0815720.1

DEPTH INTERVAL (feet)

$1.0-2.0$

$2.0-3.0$

$3 \cdot 0-5 \cdot 0$

$5.0-6.0$

$6.0-8.5$

$8.5-12.5$

$12 \cdot 5-14.0$

$14.0-15.0$

$15 \cdot 0-16.0$

\section{LITHOLOGY}

\section{Post Miocene Rocks}

White, clear to frosted, medium-to fine-grained, fairly well sorted, sub-angular to sub-rounded quartz sand; trace of dark gray clay.

Sand as above; trace of light brown clay.

95\% white to dark brown, clear to frosted, fine-to medium-grained, fairly well sorted, sub-angular to sub-rounded quartz sand; $5 \%$ dark brown, soft clay matrix.

Light brown, clear to frosted, fine-to medium-grained, fairly well sorted, sub-angular to sub-rounded quartz sand; trace of light brown clay.

$55 \%$ white, clear to frosted, medium-grained, fairly well sorted, sub-rounded quartz sand; $45 \%$ light brownish gray, indurated, clay matrix; trace of heavy minerals.

$60 \%$ light gray and tan mottled, indurated clay matrix; $40 \%$ white, clear to frosted, fineto medium-grained, fairly well sorted, angular to sub-rounded quartz sand; trace of heavy minerals.

$50 \%$ sand as above; $50 \%$ light gray, tan and medium brown mottled, soft, clay matrix; trace of heavy minerals.

$80 \%$ white, clear, fine-grained, fairly we11 sorted, angular quartz sand; $20 \%$ light gray to tan, soft clay; mottled with $80 \%$ purple, soft clay containing up to $20 \%$ white sand; trace of heavy minerals.

$65 \%$ sand as above; $35 \%$ tan to gray, indurated, clay matrix, banded with $1 / 8$ to $1 / 2$-inch purple bands; trace of heavy minerals.

$70 \%$ sand as $12.5-14.0$ interval; $30 \%$ tan, light gray, brownish gray and purple mottled, indurated clay matrix; trace of heavy minerals. 
$16.0-18.0$

$18.0-18.5$

$18 \cdot 5-20.0$

$20.0-25.0$

$25.0-27.0$

$27.0-29.0$

$29.0-31.0$

$31.0-33.0$

$33.0-34.0$
$60 \%$ sand as 12.5-14.0 interval but fairly well sorted; $40 \%$ light to medium brownish gray, soft to indurated clay matrix; trace of heavy minerals.

\section{Rocks of Miocene Age}

$75 \%$ dark gray, green, medium brown and tan mottled, soft, waxy clay mottled with white indurated powdery clay; $25 \%$ white, clear, fine-grained, well sorted, sub-angular quartz sand; trace of black to tan, fine phosphate nodules.

$80 \%$ off-white, indurated, fairly we11 consolidated, calcareous clay matrix; $20 \%$ sand as above; trace of fine to medium, multicolored phosphate nodules and blades; trace of creamy, microcrystalline, indurated, porous, fossiliferous limestone fragments; contains Elphidium chipolense (Cushman).

$40 \%$ off-white, indurated, fairly well consolidated clay matrix; $30 \%$ sand as $18.0-18.5$ interval; $30 \%$ off-white microcrystalline, indurated, porous, fossiliferous limestone fragments; trace of phosphate.

$80 \%$ light tan, fine to coarse grained, indurated, porous, sandy limestone; $10 \%$ white, soft clay matrix; $10 \%$ white to clear, fine-to medium-grained, we11 sorted, angular quartz sand; trace of brown to black, fine to coarse phosphate nodules.

$90 \%$ very light gray, indurated clay matrix mottled with light greenish gray clay; $10 \%$ light tan, clear, fine-grained, well sorted, angular quartz sand; trace of foraminifera.

95\% bluish gray and brownish green mottled, indurated, waxy clay; $5 \%$ sand as above; minor white clay mottling.

Very thinly ( $1 / 16$ to 1 -inch) interbedded light greenish gray, soft, waxy, pure clay and very light gray, soft clay with trace of sand.

$70 \%$ tan to light greenish gray mottled, soft, crumbly, poorly consolidated, calcareous clay matrix; $20 \%$ light tan, coarse grained, limestone fragments; $10 \%$ white, clear, fairly well sorted, angular, finegrained quartz sand; trace of brown, coarse to fine phosphate nodules. 
$34 \cdot 0-45 \cdot 0$

$45.0-49.0$

$49.0-50.0$

$50.0-59.0$
$80 \%$ very pale greenish gray and white mottled, soft clay matrix; $20 \%$ off-white to very light gray, microcrystalline, indurated, porous, slightly sandy, fossiliferous limestone fragments.

\section{Rocks of Eocene Age}

$85 \%$ off-white to very light greenish gray, microcrystalline, hard, porous limestone fragments with some sparry calcite replacement; $10 \%$ clear, mediumto fine-grained, fairly well sorted sand; $5 \%$ black to brown, coarse to medium phosphate nodules; contains Lepidocyclina ocalana floridana (Cushman).

$55 \%$ medium brown, soft, calcareous clay; $40 \%$ fine to medium grained sand mottled with white, sof $t$, poorly consolidated, calcareous clay; $5 \%$ limestone fragments as above.

$75 \%$ tan to light gray, fine to coarse, she11 fragments and foraminifera; $20 \%$ clear, fine-to medium-grained, fairly well sorted quartz sand; $5 \%$ white, soft, unconsolidated, calcareous clay. 
LK7413

Lake County 282558N0815617.1

DEPTH INTERVAL (feet)

$0.5-1.5$

$1.5-2.5$

$2.5-4.0$

$4 \cdot 0-6 \cdot 0$

$6.0-7.0$

$7.0-10.0$

$10.0-14.0$
LITHOLOGY

\section{Post Miocene Rocks}

$70 \%$ black, soft, unconsolidated, highly organic clay; $30 \%$ white, clear, fine-grained, fairly well sorted, sub-angular, quartz sand with scattered medium grained sand.

Brown and white, fine-grained, well sorted, subrounded quartz sand with scattered medium grained sand and just enough brown clay to bind.

White, clear, fine-grained, poorly sorted, sub-angular quartz sand; just enough light tan clay to bind; abundant medium-grained sand; trace of very fine phosphate.

No sample.

$50 \%$ white, clear, very fine-grained, fairly well sorted, sub-angular quartz sand; 40\% tan, soft, clay matrix; 10\% medium grained, white, clear subrounded sand.

95\% white, clear, fine-grained, fairly well sorted, sub-angular quartz sand; $5 \%$ black to brown, very fine phosphate.

$70 \%$ white, clear, medium-grained, sub-rounded, fairly well sorted quartz sand; $30 \%$ gray to tan clay matrix.

$70 \%$ white, clear, very fine-to fine-grained, fairly we11 sorted, sub-angular quartz sand; $30 \%$ tan to light gray, well consolidated clay matrix; trace of black, very fine phosphate. 
$14.0-28.4$

$28.4-29.6$

$29.6-31.0$

$31.0-35-5$

$35.5-40.0$
$80 \%$ light brown to white, clear, fine-grained, fairly well sorted, sub-angular quartz sand; $20 \%$ tan to light gray, indurated clay matrix; $1 / 4$ to $1 / 2-$ inch wide bands of white, clear, fine-grained, fairly well sorted sand scattered throughout; 3-inch wide band of white, clear, fine-grained, well sorted, subangular, quartz sand at 21.4 feet; 6-inch wide band of white,clear, fine grained, fairly well sorted sub-angular, quartz sand at 27.5 feet; abundant medium grained sand; trace of black to brown fine to very fine phosphate.

\section{Rocks of Miocene Age}

$60 \%$ white to tan, clear, fine-grained, fairly well sorted sub-angular quartz sand; $40 \%$ 1ight gray to tan, soft clay matrix; abundant medium-grained sand; trace of black to brown, very fine phosphate.

$50 \%$ white, clear, fine-grained, fairly we11 sorted sub-angular quartz sand; $40 \%$ light greenish gray and tan mottled, soft clay matrix; $10 \%$ cream colored, small limestone fragments; trace of black to brown, fine phosphate and medium-grained sand.

White to $\tan$, indurated, very well consolidated fossiliferous clay; some replacement of fossiliferous material by light gray chert.

\section{Rocks of Eocene Age(?)}

No sample. Lost circulation at 34.4 feet; top of interval based on geophysical logs. 


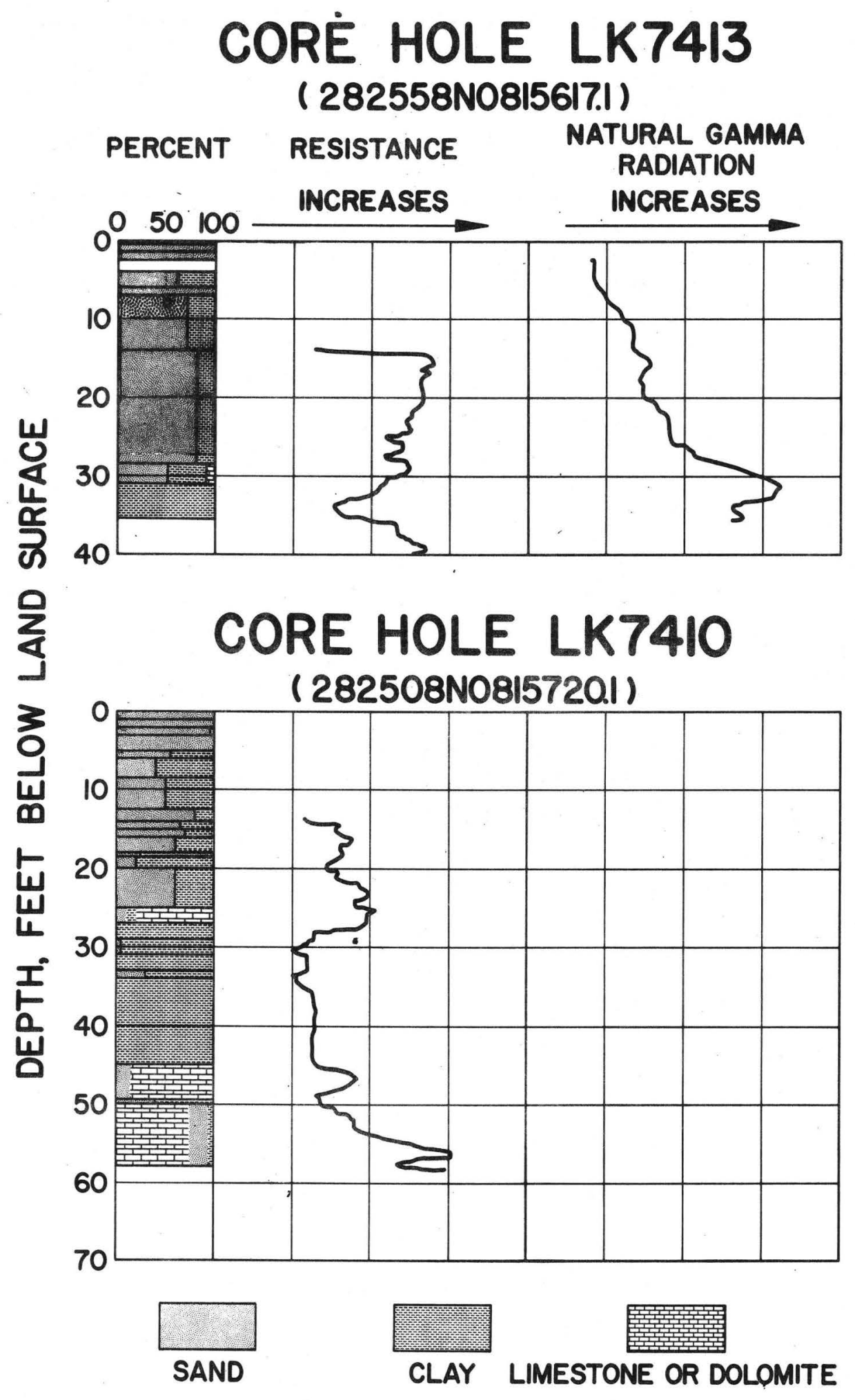


Lake County 282726 N0815616.1

DEPTH INTERVAL

(feet)

$0.0-1.0$

$1.0-4.0$

$4 \cdot 0-6 \cdot 5$

$6.5-7.5$

$7.5-9.0$

$9.0-12.0$

$12 \cdot 0-12.5$

$12 \cdot 5-13.5$

$13 \cdot 5-15 \cdot 5$

\section{LITHOLOGY}

\section{Post Miocene Rocks}

Light brown and light gray, clear to stained, fineto medium-grained, sub-angular to sub-rounded sand with just enough light gray clay to bind the sand 1oosely.

$80 \%$ tan, clear to stained, fine-to medium-grained, angular to sub-rounded sand; $20 \%$ light brown and tan, indurated clay matrix; trace of heavy minerals and lignite.

$65 \%$ white, clear to frosted, fine-grained, fairly we11 sorted, angular sand; $30 \%$ dul1 yellow, soft, clay matrix with minor light brown and white mott1ing; $5 \%$ medium-grained sand.

$50 \%$ sand as above; $50 \%$ white, indurated, clay matrix with minor light brown mottling; trace of heavy minerals.

$55 \%$ white, yellow and orange, clear to stained, finegrained, fairly well sorted, angular sand; $40 \%$

light brown, tan and white banded, soft clay matrix; $5 \%$ medium-grained sand; clay bands are $1 / 32$ to 1/4-wide.

$50 \%$ white, frosted, fine-to medium-grained, angular to sub-rounded sand; $50 \%$ white and light brown mottled, soft clay matrix.

$55 \%$ white, soft clay matrix; $40 \%$ white, frosted, medium-grained, fairly we11 sorted, sub-rounded sand; $5 \%$ coarse-to very coarse-grained sand.

$50 \%$ white, yellow and orange, clear to stained, finegrained, angular, well sorted sand; $50 \%$ medium brown, indurated clay matrix with minor white banding.

$60 \%$ white, clear to frosted, fine-grained, angular, well sorted sand; $40 \%$ white, indurated clay matrix. 
$15 \cdot 5-18.2$

$18.2-20.5$

$20.5-21.5$

$21.5-23.5$

$23.5-25.0$

$25.0-26.0$

$26.0-27.0$

$27.0-28.0$

$28.0-28.7$

$28.7-30.5$
$60 \%$ sand as above; $40 \%$ white and light brown mottled, indurated clay matrix.

$60 \%$ white, clear to frosted, fine-to medium-grained, angular to sub-rounded sand; $40 \%$ white and medium brown mottled, indurated clay matrix.

\section{Rocks of Miocene Age}

$60 \%$ white, light brown, indurated clay matrix; $40 \%$ white, clear to frosted, fine-grained, angular, well sorted sand; trace of heavy minerals.

$80 \%$ medium brown and very pale green banded, indurated, waxy clay matrix with $1 / 16$ to $1 / 2$-inch bands of sand as below; $20 \%$ white, clear, fine-to mediumgrained, angular to rounded sand; trace of white, fine to medium phosphate nodules.

$70 \%$ medium to dark brown, very pale green and white mottled, indurated clay matrix; $30 \%$ sand as above; trace of phosphate and black organic material.

$75 \%$ white, clear to frosted, fine-to medium-grained, angular to sub-rounded sand; $25 \%$ white, indurated, crumbly clay matrix; trace of heavy minerals and multicolored, coarse to very coarse phosphate nodules.

$80 \%$ light brown, very pale green and white banded, soft, waxy clay matrix with minor black and dark brown streaking; 20\% 1ight gray, frosted, mediumto fine-grained sub-angular to rounded sand; trace of heavy minerals and phosphate.

$60 \%$ tan and white banded, indurated clay matrix with minor black and dark brown streaking; $40 \%$ sand as above; trace of phosphate.

$60 \%$ white, indurated, crumbly clay matrix; $40 \%$ sand as 26.0-27.0 interval; trace of medium phosphate nodules.

$60 \%$ white, light brown and very pale green mottled, indurated clay matrix, with minor black and brown streaking; $40 \%$ sand as $26.0-27.0$ interval; trace of phosphate. 
$30.5-31.5$

$31.5-32.5$

$32.5-34.5$

$34.5-36.0$

$36.0-36.7$

$36.7-39.7$

$39.7-40.5$

$40.5-41.5$

$41.5-46.2$
$60 \%$ white, medium and light brown banded, indurated clay matrix; $40 \%$ sand as $26.0-27.0$ interval; trace of phosphate.

$70 \%$ light gray, clear to frosted, fine-to mediumgrained, sub-anglular sand; $30 \%$ tan, white and light brown banded, indurated crumbly clay matrix; trace of heavy minerals and medium to coarse tan phosphate nodules.

$70 \%$ light green, white and medium brown mottled, soft clay matrix; $20 \%$ sand as above; $10 \%$ white, medium to very coarse phosphate nodules; trace of heavy minerals.

99\% medium green, soft waxy clay matrix with medium to very dark brown streaking, $1 \%$ white, clear, finegrained, angular, we11 sorted sand.

$50 \%$ light gray, clear to frosted, medium-grained, fairly well sorted, sub-angular to rounded sand; $40 \%$ medium greenish brown, soft clay matrix with banding by pure, medium green soft, waxy clay; $10 \%$ white to very light tan, medium to very coarse phosphate nodules; trace of heavy minerals.

$65 \%$ light gray, clear to frosted, fine-to mediumgrained, angular to sub-rounded sand; $35 \%$ medium to light tan, soft, crumbly clay matrix; trace of medium to very coarse, very light tan to white phosphate nodules.

$60 \%$ white and very light green mottled, indurated, fairly well consolidated clay matrix; $40 \%$ white, clear to frosted, fine-grained, angular, fairly well sorted sand; trace of heavy minerals and offwhite medium to coarse phosphate nodules.

$50 \%$ sand as above; $45 \%$ very pale green, soft clay matrix with minor light brown mottling; $5 \%$ medium to very coarse, tan and white phosphate nodules; trace of heavy minerals.

$75 \%$ white, clear to frosted, fine-grained, angular, fairly well sorted sand; $25 \%$ very pale green and dull yellow banded, soft crumbly clay matrix with minor black and very dark brown organic material; trace of medium to very fine off-white phosphate nodules. 
$46.2-51.0$

$51.0-52.0$

$52.0-53.0$

$53.0-56.5$

$56.5-58.5$

$58.5-59.5$

$59 \cdot 5-60.0$

$60.0-61.0$

$61.0-63.0$

$63.0-66.0$

$66.0-67.0$

$67.0-77.0$

$77.0-83.7$
$60 \%$ white and light brown mottled, indurated, crumbly clay matrix; $40 \%$ white, clear to frosted, fine-to medium-grained, angular to sub-rounded sand; trace of tan, fine to very coarse phosphate nodules.

$80 \%$ off-white, hard, slightly calcareous, well consolidated siltstone; $20 \%$ white, fine-grained, sand; trace of tan, fine phosphate nodules.

Very light gray, soft clay; trace of tan, fine to coarse, phosphate nodules and white, fine-grained sand.

No sample.

Very light gray, hard, platy, silty clay.

Very light greenish gray, hard, well consolidated clay; trace of light brown and tan, fine to medium phosphate nodules.

Light greenish gray, hard, platy clay.

Medium green, hard, platy clay.

$70 \%$ very light gray, indurated, crumbly, calcareous clay; $30 \%$ coarse to very coarse fragments of pisolitic silica; trace of tan to brown, medium phosphate nodules, medium-grained sand.

No sample.

95\% light gray, microcrystalline, hard, fairly tight limestone; $5 \%$ white, clear, fine-to medium-grained sand; trace of brown to tan, fine to medium phosphate nodules. Highly weathered.

No sample.

\section{Rocks of Eocene Age(?)}

No sample. Lost circulation at 77 feet. Cavity from 77 to 80 feet. 


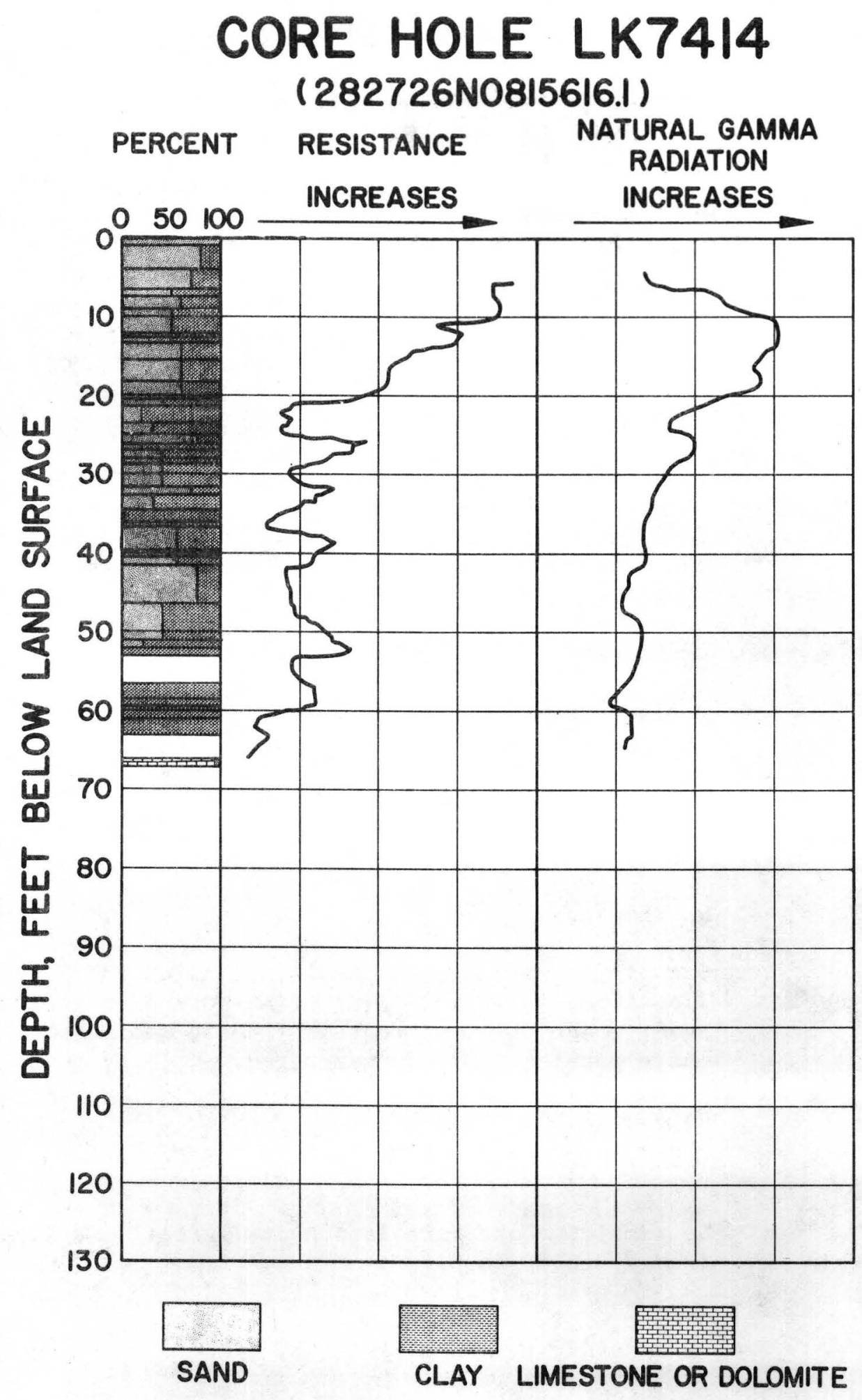


LK7411

Lake County

282844N0815305.1

DEPTH INTERVAL (feet)

$0.0-3.0$

$3.0-5.0$

$5 \cdot 0-6.0$

$6.0-12.0$

$12.0-18.5$

$18.5-21.5$

$21.5-23.5$

$23.5-32.0$

$32.0-38.0$

$38.0-41.0$

$41.0-43.0$

$43.0-48.0$

$48.0-69.5$
LITHOLOGY

\section{Post Miocene Rocks}

White to light brown, clear to frosted, medium-grained, fairly well sorted, sub-rounded quartz sand; trace of light gray to brown clay. Not enough clay to bind the sand.

No sample.

$75 \%$ white, clear, medium-grained, fairly well sorted sub-rounded quartz sand; $25 \%$ brownish gray, soft clay with du11 orange bands.

95\% white, clear to frosted, medium-grained, fairly well sorted, sub-rounded quartz sand; $5 \% 1$ ight brownish gray and white mottled clay matrix.

No sample.

$85 \%$ white, clear to frosted, medium-grained, poorly sorted, sub-angular quartz sand; $15 \%$ brownish gray and yellow mottled, soft clay matrix.

$80 \%$ sand as above; $20 \%$ medium brown, soft clay matrix.

$75 \%$ sand as $18.5-21.5$ interval; $25 \%$ light brown and light tan mottled, soft clay matrix.

$70 \%$ sand as $18.5-21.5$ interval; $30 \%$ brown, soft clay matrix; trace of heavy minerals.

Sand as 18.5-21.5 interval; just enough clay to bind sand.

$75 \%$ sand as $18.5-21.5$ interval; $25 \%$ medium brown to tan, soft clay matrix.

95\% white to yellow, clear to frosted, coarsegrained, fairly well sorted, sub-rounded quartz sand; $5 \%$ tan, soft clay matrix; trace of heavy minerals.

No sample. 
$69.5-73.0$

$73.0-78.0$

$78 \cdot 0-80.5$

$80.5-83.5$

$83.5-86.0$

$86.0-96.0$
$70 \%$ dark gray and dark brownish gray banded, soft clay matrix, $30 \%$ white to light gray, clear, well sorted, angular, fine-grained quartz sand.

\section{Rocks of Miocene Age}

$70 \%$ 1ight gray, clear, fine-grained, fairly well sorted, angular quartz sand; $30 \%$ brownish gray, soft clay matrix.

$50 \%$ white to light gray, clear to frosted, mediumgrained, fairly well sorted, sub-rounded quartz sand; $50 \%$ dark gray to dark brownish gray, soft clay matrix. Entire interval is irregularly interbedded with thin $1 / 8$ to $1 / 4-$ inch beds of clay and sand. Abundant coarse black phosphate, trace of white, soft gypsum.

No sample.

$50 \%$ white to light gray, clear, fine-grained, fairly well sorted, sub-angular to angular quartz sand; $50 \%$ very dark gray to very dark brownish gray mottled and banded, soft clay matrix.

$85 \%$ sand as above; $15 \%$ dark brown, soft clay. 


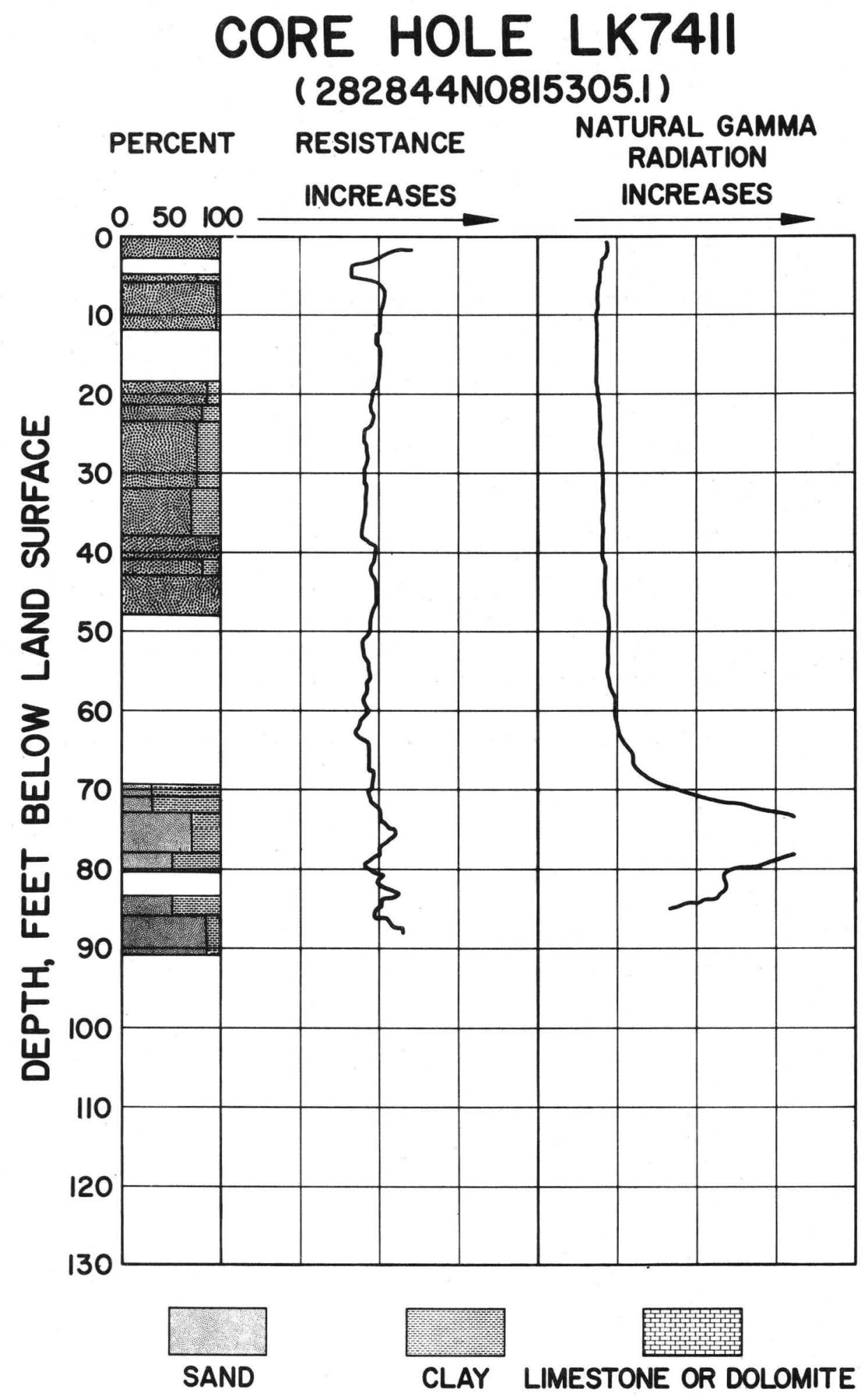


Lake County 282722N0814844.1

DEPTH INTERVAL (feet)

$0.0-3.0$

$3.0-5.5$

$5 \cdot 5-12.0$

$12.0-18.0$

$18.0-23.0$

$23.0-30.0$

$30.0-34.0$

$34.0-38.0$

$38.0-42.5$

$42 \cdot 5-50.0$

\section{LITHOLOGY}

\section{Post Miocene Rocks}

$90 \%$ tan, medium-grained, fair $1 y$ we11 sorted, subrounded quartz sand; $10 \%$ tan clay; trace of lignite.

$70 \%$ white with light orange tint, medium-grained, fairly well sorted, sub-angular to sub-rounded quartz sand; $30 \%$ tan to light orange to white, mottled soft clay.

$70 \%$ light tan, medium-grained, fairly well sorted, sub-rounded quartz sand; $30 \%$ tan to light orange to white mottled, soft clay.

$80 \%$ white, frosted, coarse-grained, rounded, fairly we11 sorted quartz sand; $20 \%$ tan to light orange to white mottled soft clay.

$65 \%$ sand as above; $35 \%$ orange and tan mottled, soft clay; a few very small quartz pebbles.

$50 \%$ white, frosted, fine-grained, poorly sorted, sub-rounded quartz sand; $50 \%$ white soft clay matrix; abundant medium to coarse sand grains.

$75 \%$ white, clear to frosted, medium grained, poorly sorted, sub-rounded quartz sand; $25 \%$ white, soft clay matrix; trace of muscovite.

$65 \%$ white, clear, very fine-grained, well sorted, sub-angular quartz sand; $30 \%$ white, soft clay matrix; $5 \%$ fine muscovite flakes; abundant white, frosted, coarse grained, rounded quartz sand.

$70 \%$ white, clear, very fine-grained, very we11 sorted, angular quartz sand; $25 \%$ white, soft clay matrix; $5 \%$ fine muscovite flakes.

$80 \%$ white, clear, very fine-grained, very well sorted, angular quartz sand; $20 \%$ white, soft clay matrix; trace of fine muscovite flakes. 
Rocks of Miocene Age

$50.0-59.0$

$59.0-68.0$

$68.0-69.0$

$69.0-72.0$

$72.0-79.0$

$79.0-80.0$

$80.0-82.0$

$82.0-83.0$

$83.0-85.0$
$70 \%$ white, clear, very fine-grained, well sorted, angular quartz sand with abundant clear, mediumgrained, rounded sand; $30 \%$ white, soft clay matrix; trace of very fine, black phosphate.

$85 \%$ sand as above; $15 \%$ light gray, soft clay matrix; trace of marcasite; trace of fine black phosphate.

$70 \%$ light gray, fine-grained, fairly well sorted, sub-angular quartz sand; $30 \%$ light brownish gray to dark gray mottled and banded, soft, clay; trace of lignite and marcasite; trace of white, soft, very fine crystalline gypsum.

$60 \%$ light gray, fine-grained, well sorted, subangular quartz sand; $40 \%$ light to medium gray, mottled and subtly banded soft gray clay.

$90 \%$ white, clear, fine-grained, we11 sorted, subangular quartz sand; $10 \%$ light gray, soft clay matrix.

$65 \%$ white, clear, medium-grained, fairly wel1 sorted, sub-rounded quartz sand; 35\% light gray, indurated clay with a few streaks of pure clay in matrix; abundant coarse to fine, light gray to black phosphate; trace of pisolitic silica.

$65 \%$ white, clear, fine-grained, poorly sorted, sub-angular quartz sand; $35 \%$ light gray to creamy to tan mottled, soft clay matrix; phosphatic fossil material and large and small, black to very light gray phosphate nodules.

$70 \%$ white, clear, very fine-grained, well sorted, angular quartz sand; $30 \%$ creamy, soft clay matrix; abundant very fine, green glauconite; trace very light gray, small phosphate nodules.

$35 \%$ light tan, soft clay matrix; $35 \%$ large to sma11, brown to black phosphate nodules and phosphatic fossil material; 30\% white, fine-grained, well sorted, sub-angular quartz sand. 
$85.0-88.0$

$88.0-90.0$

$90.0-92.0$

$92.0-95.0$

$95.0-96.0$

$96.0-101.0$

$101.0-121.7$
$60 \%$ off-white to very light gray, indurated clay matrix with light green to gray to cream mottling; $20 \%$ sand as above; $20 \%$ phosphate and phosphatic fossil material as above. Interval has bands of pure clay throughout.

$80 \%$ very light gray, soft clay matrix; $10 \%$ sand as 83.0-85.0 interval; $10 \%$ phosphate as $85.0-88.0$ interval.

$80 \%$ light greenish gray, soft clay matrix; $10 \%$ sand as $83.0-35.0$ interval; $10 \%$ phosphate as $85.0-88.0$ interval.

$65 \% 1$ 1ight gray, indurated, clay matrix; $25 \%$ white, clear, fine grained, well sorted, sub-angular quartz sand; $10 \%$ fine to medium, brown to black, phosphate nodules.

$70 \%$ light to dark greenish gray to cream mottled, indurated clay matrix; $20 \%$ sand as above; $10 \%$ fine to coarse, black to brown phosphate nodules.

$60 \%$ light greenish gray, indurated clay matrix; $20 \%$ sand as 92.0-95.0 interval; $20 \%$ fine to coarse, brown to black phosphate nodules.

\section{$\underline{\text { Rocks of Eocene Age }}$}

White limestone, soft to hard; drilling tool dropped into a 2-foot cavity at 101.0 feet. 


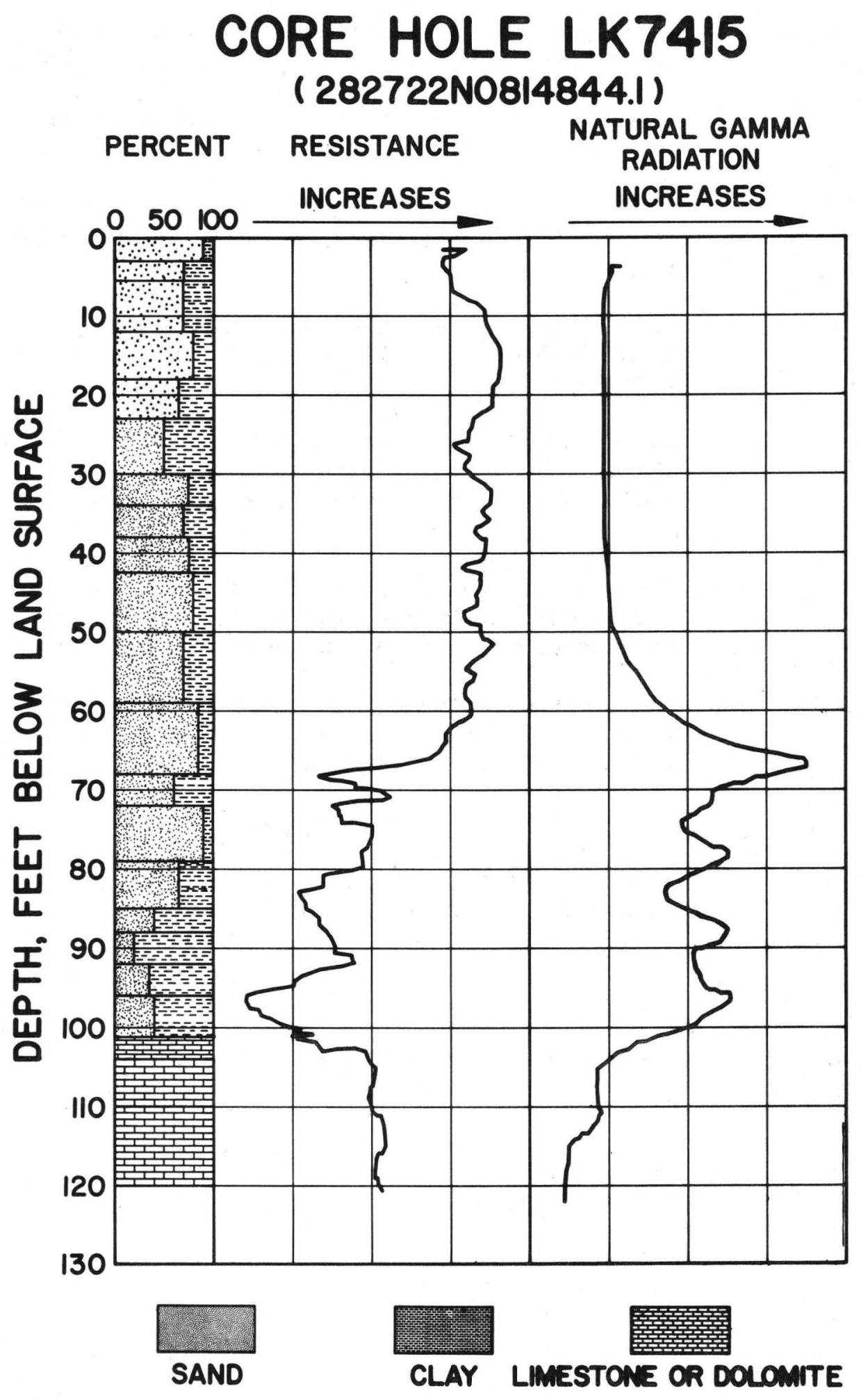


LK7416

Lake County 282529N0815135.1

DEPTH INTERVAL (feet)

$0.0-3.2$

$3.2-6.0$

$6.0-9.0$

$9 \cdot 0-12.0$

$12.0-12.5$

$12 \cdot 5-13.5$

$13.5-16.0$

$16.0-19.0$

$19.0-21.0$

$21.0-24.0$

\section{LITHOLOGY}

\section{Post Miocene Rocks}

$80 \%$ white to light gray to light brown, clear to stained, medium grained, fairly well sorted, subangular to sub-rounded quartz sand; $10 \%$ coarse to very coarse-grained sand; $10 \%$ dark gray, soft clay matrix.

No sample.

$60 \%$ very light tan, stained, medium-grained, fairly we11 sorted, sub-rounded quartz sand; 30\% light brown, to very light tan mottled soft clay; $10 \%$ coarse to very coarse-grained sand.

No sample.

$80 \%$ white with light pink cast, clear to frosted, medium to coarse-grained, poorly sorted, sub-rounded quartz sand; $20 \%$ very light tan with pink cast, soft clay matrix.

$90 \%$ white with slight pink cast, clear to frosted, medium to coarse-grained, poorly sorted sub-rounded quartz sand; 10\% light brown, white and pink mottled, soft clay matrix.

$75 \%$ white, frosted, medium-to coarse-grained, fairly well sorted, sub-rounded quartz sand; $25 \%$ light tan, soft clay matrix; trace of heavy minerals.

$65 \%$ sand as above; $35 \%$ dull yellow and tan mottled, indurated to soft clay matrix; trace of heavy minerals.

$80 \%$ off-white, frosted, medium grained, fairly wel1 sorted, sub-angular to sub-rounded quartz sand; $20 \%$ light tan and medium brown banded, indurated clay matrix; trace of heavy minerals.

$60 \%$ white, frosted, medium-grained, poorly sorted, sub-rounded quartz sand; $40 \%$ light gray with tan cast, soft clay matrix; trace of heavy minerals. 
$24.0-26.0$

$26.0-27.0$

$27.0-28.0$

$28.0-30.0$

$30.0-33.5$

$33.5-43.5$

$43.5-44.0$

$44.0-49.0$

$49.0-54.0$

$54.0-55.0$

$55.0-55.5$
$85 \%$ white to very light brown, clear to frosted, medium-to coarse-grained, poorly sorted, sub-rounded to rounded quartz sand; $15 \%$ light tan and light brown mottled, soft clay; trace of heavy minerals.

$80 \%$ white, frosted, medium-to coarse-grained, subrounded quartz sand; $20 \%$ light tan, light brown and dull yellow mottled, indurated clay matrix; trace of heavy minerals.

$75 \%$ white to 1 ight gray, clear to frosted, mediumto coarse-grained, fairly well sorted, sub-angular to sub-rounded quartz sand; $20 \%$ very light tan, indurated clay matrix; $5 \%$ very coarse-grained sand.

$50 \%$ light tan, indurated clay matrix; $45 \%$ white to light gray, clear to frosted, medium-grained, fairly we11 sorted, sub-rounded quartz sand; $5 \%$ coarse and very coarse grained sand.

$65 \%$ sand as above; 35\% light tan, indurated, clay matrix.

$65 \%$ sand as $28.0-30.0$ interval; $35 \%$ off-white to very light gray, indurated clay matrix.

$65 \%$ white, frosted, coarse-to medium-grained, fairly wel1 sorted, sub-rounded quartz sand; 35\% light tan, soft clay matrix.

$50 \%$ white, frosted, fine-grained, silty, angular quartz sand; $40 \%$ very light gray to off-white, indurated to soft clay matrix; $10 \%$ very coarse to medium grained-sand; trace of heavy minerals. Band from 48.0-48.2 of very light tan, silty, coarse-grained sand.

$60 \%$ sand as above; $40 \%$ white, indurated to soft, fairly well consolidated clay matrix; trace of heavy minerals.

$70 \%$ sand as $44.0-49.0$ interval; $30 \%$ very 1 ight tan, soft clay matrix; trace of heavy minerals.

Same as $54.0-55.0$ but with abundant coarse to very coarse-grained quartz sand. 
$55.5-57.5$

$57.5-68.0$

$68 \cdot 0-69 \cdot 0$

$69 \cdot 0-69.5$

$69 \cdot 5-70.0$

$70.0-72.0$

$72.0-73.5$

$73.5-74.0$

$74.0-77.0$

$77.0-78.0$
$60 \%$ white, clear to frosted, fine-grained, fairly well sorted, angular, silty, microcrystalline quartz sand; $40 \%$ tan, soft clay matrix; trace of heavy minerals and very porous coarse-grained quartz sand.

Same as above but no very coarse or coarse-grained quartz sand.

\section{Rocks of Miocene Age}

$90 \%$ olive green and deep bluish green mottled, soft, sticky clay matrix; $10 \%$ white, clear, fine- to mediumgrained, angular, fairly well sorted quartz sand; trace of heavy minerals.

95\% sand as above; $5 \%$ light greenish brown, soft clay matrix mottled with pure brownish green, soft sticky clay..

$70 \%$ very dark brown, deep olive green and cream mottled, indurated, waxy clay matrix; $30 \%$ sand as $68.0-69.0$ interval.

$50 \%$ sand as $68.0-69.0$ interval; $50 \%$ medium grained, soft, sticky clay matrix. Clay and sand occur as $1 / 8$ to $1 / 16$-inch bands throughout interval.

$50 \%$ sand as $68.0-69.0$ interval; $50 \%$ light olive green, soft, fairly well consolidated clay matrix with minor medium bluish green mottling.

$60 \%$ light gray and cream mottled, soft, crumbly clay matrix; $40 \%$ white, clear to frosted, fine-to mediumgrained, angular to sub-rounded quartz sand; trace of pyrite.

$60 \%$ light green to cream, off-white, light brown and light gray mottled, soft, crumbly clay matrix; $40 \%$ white, clear to frosted, fine-to medium-grained, fairly well sorted, angular to sub-rounded quartz sand; trace of heavy minerals; trace of black to brown to tan, fine to very coarse phosphate nodules and blades.

$50 \%$ white, clear to frosted, fine-to medium-grained, fairly well sorted, angular to sub-rounded quartz sand; $50 \%$ deep bluish green, soft, waxy clay occurring in pockets throughout sand; trace of heavy minerals. 
$78.0-79.5$

$95 \%$ varved, light olive green and light to dark brown, soft, waxy, clay matrix mottled with white to cream, soft clay; $5 \%$ white, clear to frosted, fine-to mediumgrained, well sorted, angular, sub-rounded quartz sand.

\section{Rocks of Eocene Age}

$79 \cdot 5-80.0$

$60 \%$ white to yellow, microcrystalline, indurated, porous limestone matrix with $40 \%$ large foraminifera. Chalky and highly weathered; contains Lepidocyclina ocalana floridana (Cushman); Reussella sculptilis (Cushman) and Sphaerogypsina globula (Reuss).

$80,0-81.0$

$80 \%$ creamy, microcrysta11ine, indurated, porous limestone matrix with $20 \%$ large foraminifera; chalky and highly weathered. 


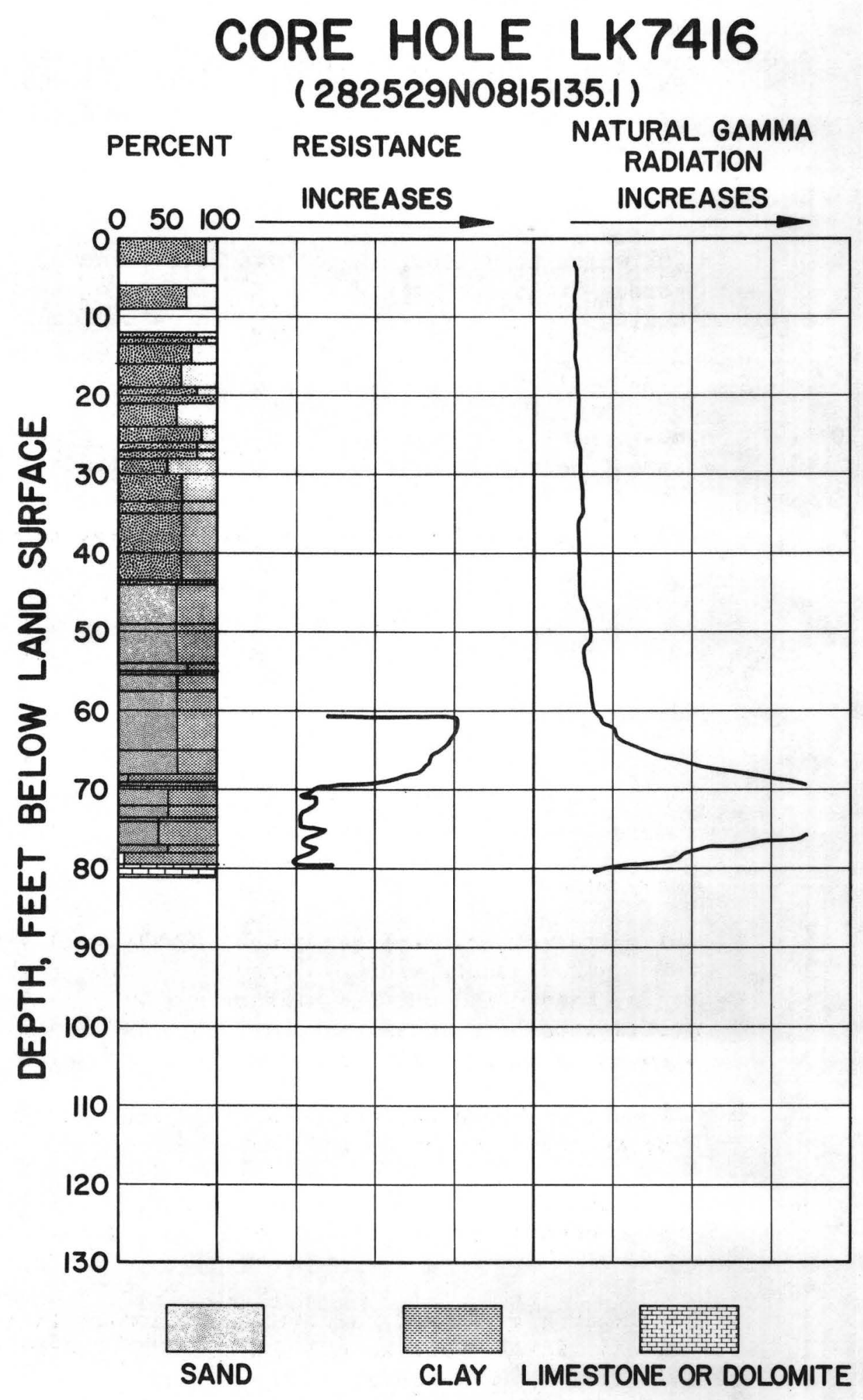


LK7417

Lake County 282314 N0815112.1

DEPTH INTERVAL (feet)

$0.0-1.0$

$1.0-3.0$

$3.0-11.5$

$11.5-12.5$

$12 \cdot 5-13.5$

$13.5-18.5$

$18 \cdot 5-19.5$

$19.5-22.0$

$22.0-22.5$

$22.5-23.5$

$23.5-28.5$

\section{LITHOLOGY}

\section{Post Miocene Rocks}

White to light brown, clear to stained, medium-grained, fairly we11 sorted, sub-rounded quartz sand; trace of light brown to light green clay.

Sand as above; trace of brown clay.

$90 \%$ sand as $0.0-1.0$ interval; $10 \%$ very dark brown and light brown mottled, soft clay matrix.

$90 \%$ sand as $0.0-1.0$ interval; $10 \%$ dark gray to tan to light brown mottled, indurated clay matrix.

$90 \%$ sand as $0.0-1.0$ interval; $10 \%$ 1ight gray and dark brown mottled, soft clay matrix.

$60 \%$ sand as $0.0-1.0$ interval; $40 \%$ medium to dark brown indurated clay matrix.

$55 \%$ light tan to white, medium-grained, clear to frosted, fairly well sorted, sub-rounded quartz sand; $45 \%$ pinkish tan, indurated clay; trace of heavy minerals.

$60 \%$ white, clear, medium-grained, fairly well sorted, sub-angular quartz sand; $40 \%$ medium to very dark brown, banded and mottled, indurated, waxy clay matrix with some very irregular, thin 1/32-inch streaks of organic material.

$60 \%$ sand as above but grains are sub-rounded; $40 \%$ clay as above but no organic material.

$80 \%$ light tan, stained, medium-grained, poorly sorted, sub-rounded quartz sand; $20 \% 1$ ight tan, indurated clay.

$65 \%$ light gray, clear to frosted, medium- to finegrained, fairly well sorted, sub-angular quartz sand; $35 \%$ light brown, indurated clay matrix. 
$28.5-29.5$

$29.5-30.5$

$30.5-31.0$

$31.0-32.0$

$32.0-32.5$

$32.5-34.0$

$34.0-35.0$

$35.0-36.0$

$36.0-37.0$

$37.0-39.0$

$39.0-40.0$

$40.0-41.0$

$41.0-45.0$
$70 \%$ sand as above, but is light tan; $30 \%$ light tan, indurated, well consolidated clay; trace of heavy minerals.

$50 \%$ light tan, clear to frosted, medium-grained, we11 sorted, sub-angular to sub-rounded quartz sand; $50 \%$ very light to light tan, indurated clay matrix; trace of heavy minerals.

$70 \%$ light gray, indurated clay with small (1/2-inch diameter) pockets of black, carbonaceous material; $30 \%$ sand as above.

$75 \%$ very light tan, indurated clay matrix; $25 \%$ white to very light tan, clear to frosted, fine-to mediumgrained, fairly well sorted, sub-rounded quartz sand.

$70 \%$ white and light brown, clear to stained, mediumgrained, fairly well sorted, rounded to sub-rounded quartz sand; $30 \%$ medium brown, indurated, we11 consolidated clay matrix.

$60 \%$ white, clear to frosted, medium-grained, fairly we11 sorted, sub-rounded quartz sand; $40 \%$ medium brown, indurated clay.

$80 \%$ sand as above; $20 \%$ light brown, indurated clay.

75\% 1ight to medium brown mottled, indurated clay matrix; $25 \%$ sand as 32.5-34.0 interval.

$80 \%$ sand as $32.5-34.0$ interval; $20 \%$ light to medium brown mottled, indurated clay; entire interval banded with dark gray, soft clay containing up to $30 \%$ sand.

$75 \%$ dark gray, dark brown and light brown mottled and banded, soft, waxy clay; $25 \%$ sand as $32.5-34.0$ interval.

$60 \%$ sand as $32.5-34.0$ interval; $40 \%$ dark gray, light brown and dark brown mottled and banded, soft clay.

$80 \%$ sand as $32.5-34.0$ interval; $20 \%$ light to medium brown mottled, indurated clay matrix; trace of heavy minerals.

$70 \%$ white, clear to frosted, medium-grained, fairly well sorted, sub-rounded quartz sand; $30 \%$ light and dark brown and medium brown, banded, indurated clay matrix. 


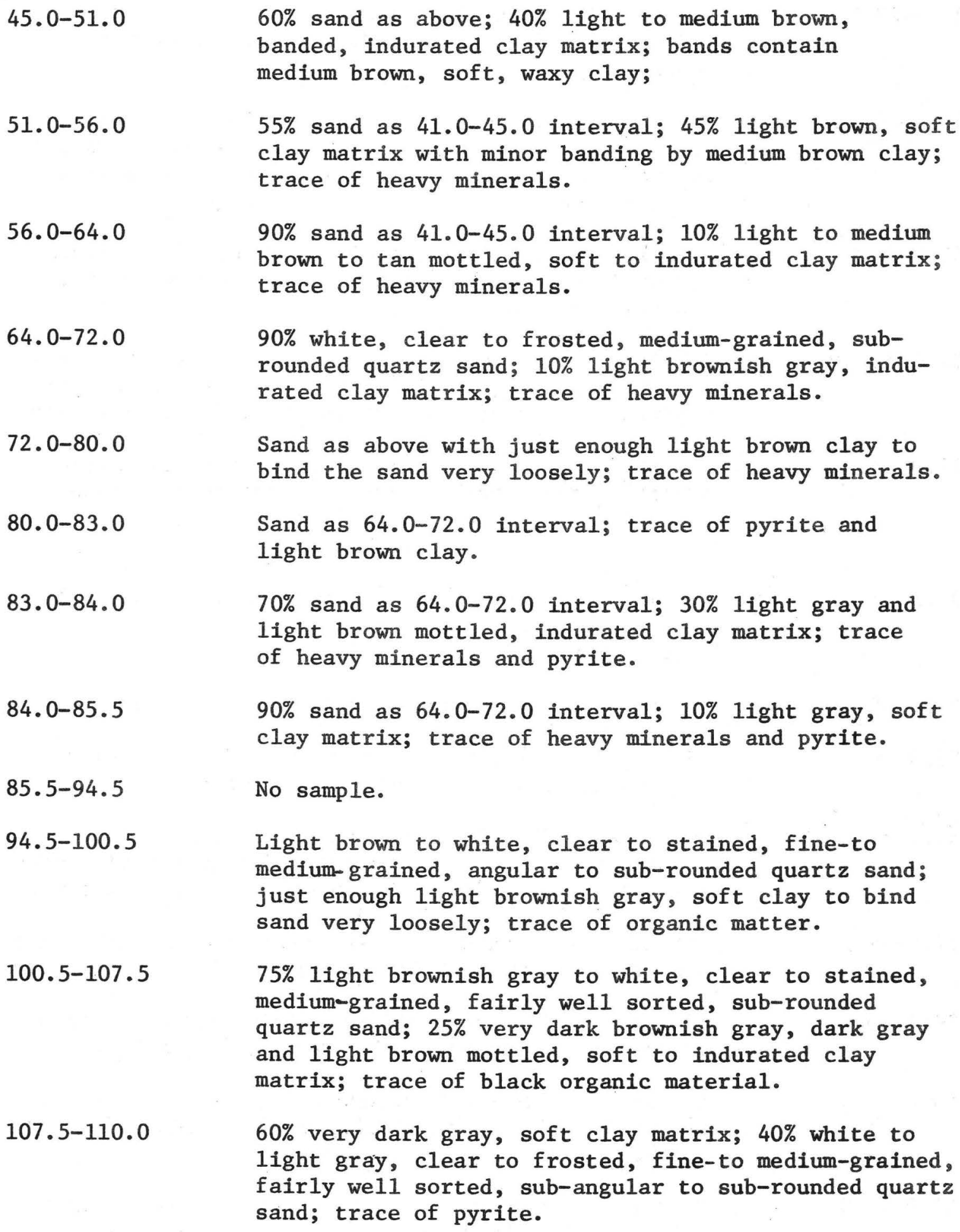

$60 \%$ sand as above; $40 \%$ 1ight to medium brown, banded, indurated clay matrix; bands contain medium brown, soft, waxy clay;

$55 \%$ sand as $41.0-45.0$ interval; $45 \%$ light brown, soft clay matrix with minor banding by medium brown clay; trace of heavy minerals.

$90 \%$ sand as $41.0-45.0$ interva1; $10 \%$ light to medium brown to tan mottled, soft to indurated clay matrix; trace of heavy minerals.

$90 \%$ white, clear to frosted, medium-grained, subrounded quartz sand; $10 \%$ light brownish gray, indurated clay matrix; trace of heavy minerals.

Sand as above with just enough light brown clay to bind the sand very loosely; trace of heavy minerals.

Sand as 64.0-72.0 interval; trace of pyrite and light brown clay.

$70 \%$ sand as $64.0-72.0$ interval; $30 \%$ light gray and light brown mottled, indurated clay matrix; trace of heavy minerals and pyrite.

$90 \%$ sand as $64.0-72.0$ interval; $10 \%$ light gray, soft clay matrix; trace of heavy minerals and pyrite.

No sample.

Light brown to white, clear to stained, fine-to medium-grained, angular to sub-rounded quartz sand; just enough light brownish gray, soft clay to bind sand very loosely; trace of organic matter.

$75 \%$ light brownish gray to white, clear to stained, medium-grained, fairly well sorted, sub-rounded quartz sand; $25 \%$ very dark brownish gray, dark gray and light brown mottled, soft to indurated clay matrix; trace of black organic material.

$60 \%$ very dark gray, soft clay matrix; $40 \%$ white to light gray, clear to frosted, fine-to medium-grained, fairly well sorted, sub-angular to sub-rounded quartz sand; trace of pyrite. 
$110.0-113.0$

$113.0-115.5$

$115.5-129.0$

$129.0-133.0$

$133.0-140.0$

$140.0-142.0$

$142.0-146.5$

$146.5-160.0$
$95 \%$ black and dark brown mottled, soft, waxy clay matrix; $5 \%$ sand as above; trace of pyrite.

Clay as above; trace of sand.

$80 \%$ light brown, stained, medium-to fine-grained, fairly well sorted, angular to sub-rounded, silty quartz sand; $20 \%$ light brown, soft clay matrix mottled with black, indurated to soft, well consolidated clay containing $60 \%$ sand; trace of white crystals of radiating gypsum.

$60 \%$ white, clear to frosted, medium-grained, we11 sorted, sub-angular to sub-rounded quartz sand; $40 \%$ light brown, soft, indurated clay matrix; trace of heavy minerals, pyrite and black organic material.

$70 \%$ white to light brown, clear to stained, mediumgrained, fairly well sorted, sub-angular to subrounded quartz sand; $30 \%$ light brown, indurated to soft clay matrix with minor medium brown mottling; trace of pyrite, heavy minerals and white, radiating crystals of gypsum.

\section{Rocks of Miocene Age}

$60 \%$ sand as above; $40 \%$ light and medium brown mottled, soft clay matrix; trace of pyrite and gypsum.

$55 \%$ light gray, clear to frosted, medium-grained, fairly well sorted, rounded to sub-rounded quartz sand; $45 \%$ black, soft, poorly consolidated clay matrix; trace of gypsum, black organic material, marcasite, silicified limestone fragments and coarse to very coarse, black phosphate nodules.

\section{$\underline{\text { Rocks of Oligocene Age }}$}

95\% 1ight gray, microcrystalline, hard, porous, highly weathered limestone matrix with abundant fossil material. 5\% medium-grained, clear, subangular to sub-rounded quartz sand; some sparry calcite replacement of limestone; at 155 feet turns to tan and light green mottled, soft, highly weathered fossiliferous limestone mottled with black soft clay. 
Lake County 282157N0815258.1

DEPTH INTERVAL (feet)

$1.0-1.5$

$1.5-2.0$

$2 \cdot 0-4.0$

$4.0-8.5$

$8 \cdot 5-19.0$

$19.0-20.5$

$20.5-25.5$

$25 \cdot 5-28.0$

LITHOLOGY

\section{Post Miocene Rocks}

95\% white to light brown, clear to frosted, mediumgrained, fairly well sorted, sub-rounded quartz sand; 5\% dark gray to dark brown, soft clay matrix; trace of heavy minerals and black, fine to medium phosphate.

Very light tan, clear to frosted, medium-to finegrained, sub-angular to sub-rounded quartz sand.

Sand as 0.0-1.0 interval with just enough dark brown, soft clay to bind sand very loosely.

White to brown, loose, medium-grained sand.

$80 \%$ white to light tan, clear to frosted, mediumgrained, fairly well sorted, sub-rounded quartz sand; $20 \%$ medium to light brown, soft, fairly we11 consolidated clay matrix; trace of heavy minerals.

95\% white, clear to frosted, medium grained, fairly well sorted, sub-rounded quartz sand; 5\% light brown to gray, soft clay matrix; contains a few thin (1/4-inch), dull yellow bands; trace of heavy minerals.

$80 \%$ white, clear, fine-grained, fairly we11 sorted, sub-angular quartz sand; $20 \%$ medium brownish gray, soft clay matrix; trace of heavy minerals.

$75 \%$ white, clear, medium-to fine-grained, fairly we11 sorted, sub-rounded quartz sand; $25 \%$ light brownish gray, soft clay matrix; contains a 3-inch band of white, fine grained sand at 24.9 feet; trace of heavy minerals.

$60 \%$ white, clear to frosted, fine-to medium-grained, fairly well sorted, sub-angular to sub-rounded quartz sand; $40 \%$ buff, soft, fairly we 11 consolidated clay matrix; trace of coarse grained sand and heavy minerals. 
$60 \%$ sand as above; $40 \%$ dark gray, indurated, we 11 consolidated clay matrix; trace of heavy minerals; a few white, soft clay inclusions.

\section{$\underline{\text { Rocks of Miocene Age }}$}

$29.0-35.0$

$69 \%$ blue green, light brown and white mottled, soft clay matrix; $40 \%$ white, clear, fine-grained, fairly well sorted, sub-angular quartz sand; many small nodules of cream, soft, fine sandy clay; trace of heavy minerals.

$35.0-40.0$

$50 \%$ blue green, soft clay matrix; $35 \%$ white, clear, fine grained, fairly well sorted, angular quartz sand; $10 \%$ white to light gray, pisolitic silica; $5 \%$ black to tan, phosphate and phosphatic fossil fragments.

\section{Rocks of Eocene Age}

$40.0-45.0$

$50 \%$ cream, microcrystalline, indurated, porous, highly fossiliferous limestone; $50 \%$ cream to offwhite, soft, calcareous, chalky, clay matrix; contains Sphaerogypsina globula (Reuss), Reussella sculptilis (Cushman), Lepidocyclina ocalana floridana (Cushman), and Cibicides mississippiensis ocalanus (Cushman). 


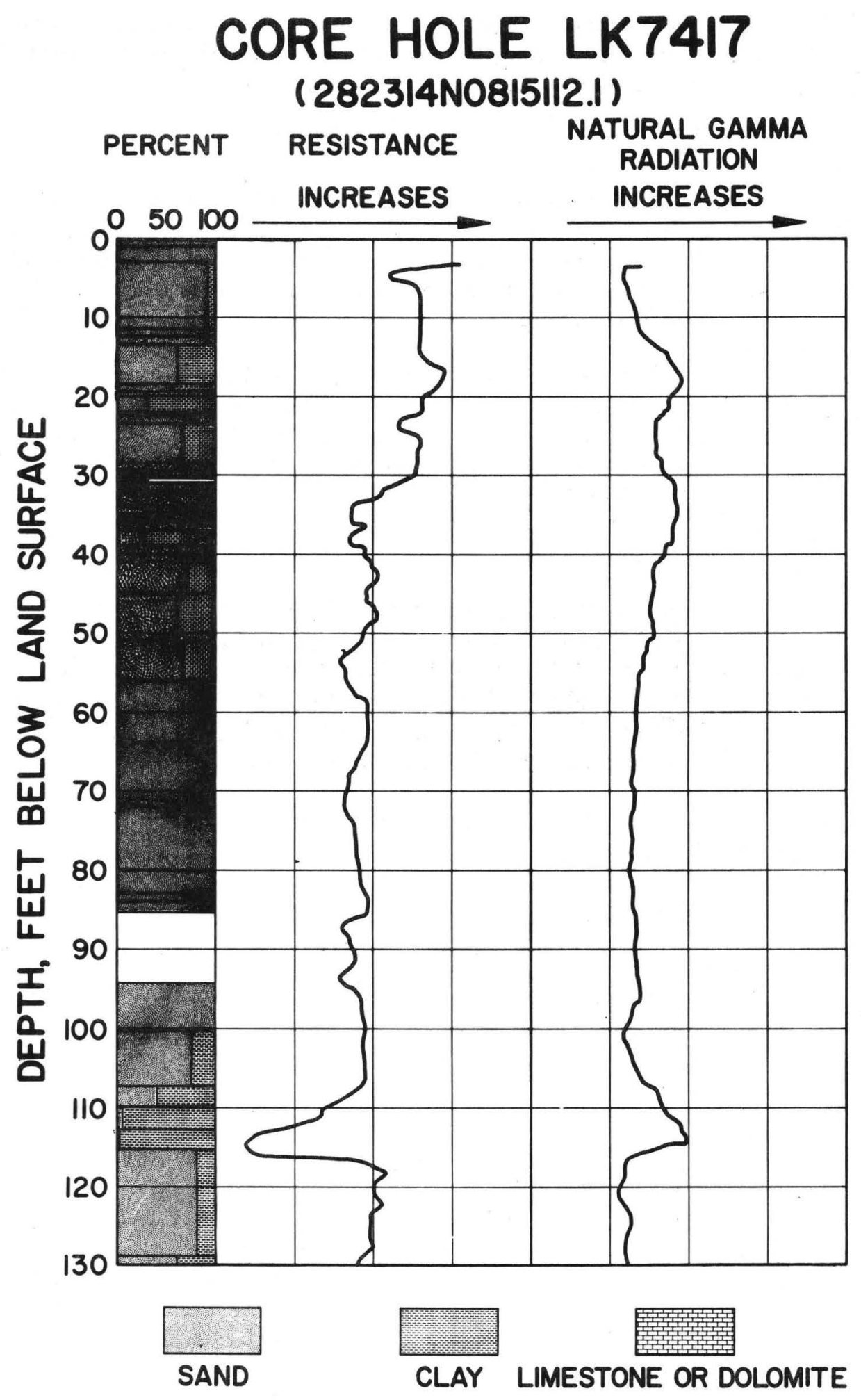




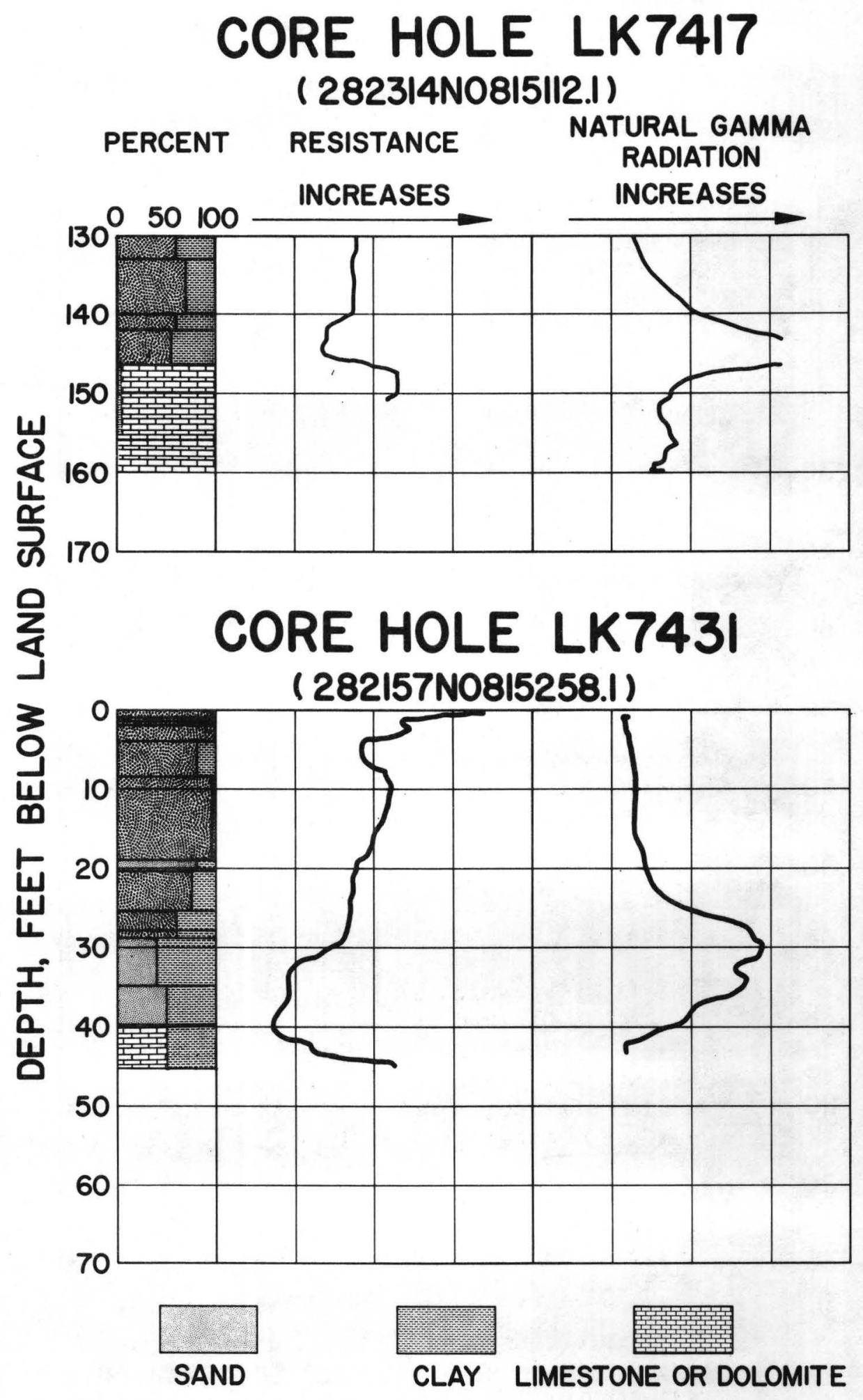


LK7418

Lake County 282840N0814816.1

DEPTH INTERVAL (feet)

$7.0-8.0$

$8 \cdot 0-10.0$

$10.0-20.0$

$20.0-26.0$

$26.0-28.0$

$28.0-30.0$

$30.0-40.0$

$40.0-46.0$

$46.0-59.0$

\section{LITHOLOGY}

\section{$\underline{\text { Post Miocene Rocks }}$}

No sample.

$60 \%$ white, clear to frosted, medium-grained, poorly sorted, sub-rounded quartz sand; 40\% light gray, soft, clay matrix with pink and yellow mottling.

$70 \%$ light greenish gray, indurated clay matrix with pink banding and mottling; $30 \%$ white, clear, finegrained, fairly we11 sorted, sub-angular quartz sand.

$60 \%$ white, clear to frosted, fine-grained, we11 sorted, sub-rounded quartz sand; $40 \%$ clay as $7.0-8.0$ interval.

70\% white, clear to frosted, fine-grained, poorly sorted sub-angular quartz sand; $30 \%$ tan, soft, poorly consolidated clay matrix; abundant medium- to coarsegrained sand; trace of heavy minerals.

$70 \%$ white, clear, fine-grained, fairly we11 sorted, sub-angular quartz sand; $30 \%$ tan, soft clay matrix; trace of heavy minerals and medium-grained sand.

95\% light brownish gray, soft clay matrix; $5 \%$ finegrained scattered sand.

$70 \%$ white to light gray, clear to frosted, fine-to medium-grained, poorly sorted, sub-rounded quartz sand; $30 \%$ light gray to light tan, soft clay matrix.

$60 \%$ clear to frosted, fine-to medium-grained, poorly sorted, sub-angular to sub-rounded quartz sand; $40 \%$ medium brownish gray, soft clay; banded throughout with bands of pure sand.

No sample.

$50 \%$ dark gray, high1y organic, soft clay matrix; $45 \%$ white to light gray, clear to frosted, finegrained, poorly sorted, sub-angular quartz sand; $5 \%$ massive marcasite; many bands and streaks of pure clay. 
$59.0-64.5$

$64.5-65.5$

$65.5-72.0$

$72.0-79.0$

$79.0-81.0$

$81.0-95.0$

$95.0-98.0$

$98.0-109.0$

$109.0-111.0$

$111.0-114.0$

$114.0-123.0$
$60 \%$ white to light gray, clear to frosted, finegrained, poorly sorted quartz sand; $40 \%$ dark brownish gray, soft clay matrix; abundant coarse-to medium-grained sand.

$60 \%$ white, clear, fine-grained, fairly well sorted, sub-angular quartz sand; $40 \%$ very dark gray, soft clay matrix; scattered medium and coarse-grained sand.

$70 \%$ very dark greenish gray to black, soft, waxy clay; 20\% 1ight gray, fine-grained, well sorted, subangular quartz sand; $10 \%$ marcasite; some lenses and pods of pure clay; very sandy bands at 67 feet and 71 feet.

$50 \%$ white to light gray, clear to frosted, finegrained, fairly well sorted, sub-angular quartz sand; $50 \%$ dark gray to dark brownish gray, indurated clay matrix; a 2-inch band of fine-grained sand in $10 \%$ soft clay matrix at 73 feet and a 1-inch band of same at 74 feet, a 1/2-inch band of fine-grained sand in just enough clay to bind very poorly at 74.5 feet.

$65 \%$ light gray, clear to frosted, fine-grained, fairly well sorted, sub-angular quartz sand; $35 \%$ black, soft clay matrix; abundant medium-grained sand.

95\% light gray, clear to frosted, fine-to mediumgrained, sub-angular to sub-rounded quartz sand; $5 \%$ gray, soft clay matrix.

No sample.

Same as $81.0-95.0$ interval.

No sample.

$60 \%$ white, clear to frosted, fine-grained, we11 sorted, sub-angular quartz sand; $40 \%$ gray and grayish brown banded, indurated clay matrix.

$65 \%$ white, clear to frosted, fine-grained, well sorted, sub-angular quartz sand; $35 \%$ tan, soft with streaks and bands of dark gray pure clay; clay is indurated from 114.0-115.5 feet; clay is soft from 115.5-116. 0 feet; clay is indurated from 116.0-117.1 feet and contains very little grayish color. 
$123.0-132.0$

$132.0-139.0$

$139.0-146.0$

$146.0-154.0$

$154.0-167.0$

$167.0-169.0$

$169.0-186.0$

$186.0-187.0$

$187.0-191.0$

$191.0-199.0$

$199.0-202.0$
$80 \%$ white, clear to frosted, fine-grained, poorly sorted, sub-angular to rounded quartz sand; $20 \%$ light gray, soft clay matrix; trace of coarsegrained sand.

$85 \%$ sand as above; $15 \%$ light brownish gray, soft, poorly consolidated clay matrix.

Sand as 123.0-132.0 interva1; 10\% 1ight brownish gray, soft, poorly consolidated clay matrix.

No sample.

$60 \%$ white, clear, fine-grained, fairly well sorted, sub-angular quartz sand; $40 \%$ brownish gray to black clay; sand is interbedded and interlensed within the clay; trace of fine phosphate nodules.

$75 \%$ white, clear to frosted, fine-grained, fair1y well sorted, sub-rounded quartz sand; $25 \%$ gray and tan, interbedded, soft clay matrix; abundant medium and coarse-grained sand; clay becomes very dark gray from 168.6-169.0 feet.

$60 \%$ light gray, clear, fine-grained, fairly well sorted, sub-angular quartz sand; $40 \%$ tan and very dark gray mottled, soft clay matrix; abundant coarsegrained sand; trace of heavy minerals and marcasite.

Sand and clay as above with many lenses of pure, very dark gray, soft, waxy clay.

$60 \%$ light gray, clear to frosted, medium-grained, subrounded, poorly sorted quartz sand; $40 \%$ dark gray, indurated clay matrix; numerous very sandy lenses and pure clay bands throughout interval; abundant light gray, clear to frosted, coarse-grained quartz sand.

$50 \%$ white, clear to frosted, coarse-grained, fairly well sorted, rounded quartz sand; $50 \%$ dark gray, black, organic, soft, waxy clay matrix.

$65 \%$ white, clear to frosted, fine-grained, poorly sorted, sub-angular quartz sand; $35 \%$ tan and dark gray banded, soft clay matrix; abundant coarse-to medium-grained sand; trace of marcasite and heavy minerals. 
$202.0-204.0$

$204.0-209.0$

$209.0-210.0$

$210.0-211.0$

$211.0-217.0$

$217.0-220.0$

$220.0-227.0$
$50 \%$ sand as above; $50 \%$ very dark gray, soft clay matrix.

No sample.

$65 \%$ white, clear, fine-grained, fairly well sorted, sub-rounded quartz sand; $35 \%$ tan to dark gray mottled, soft clay; trace of chert and small shell fragments.

$85 \%$ sand as above; $15 \%$ light brownish gray, soft clay.

$70 \%$ white to light gray, clear to frosted, mediumgrained, poorly sorted, rounded quartz sand; $30 \%$ very dark gray soft clay matrix with many pockets of pure clay. A 1/4-inch streak of black, soft, waxy, fossiliferous clay shale at 212.8 feet; trace of marcasite.

No sample.

\section{Rocks of Eocene Age}

Light brown, microcrystalline, porous limestone. 


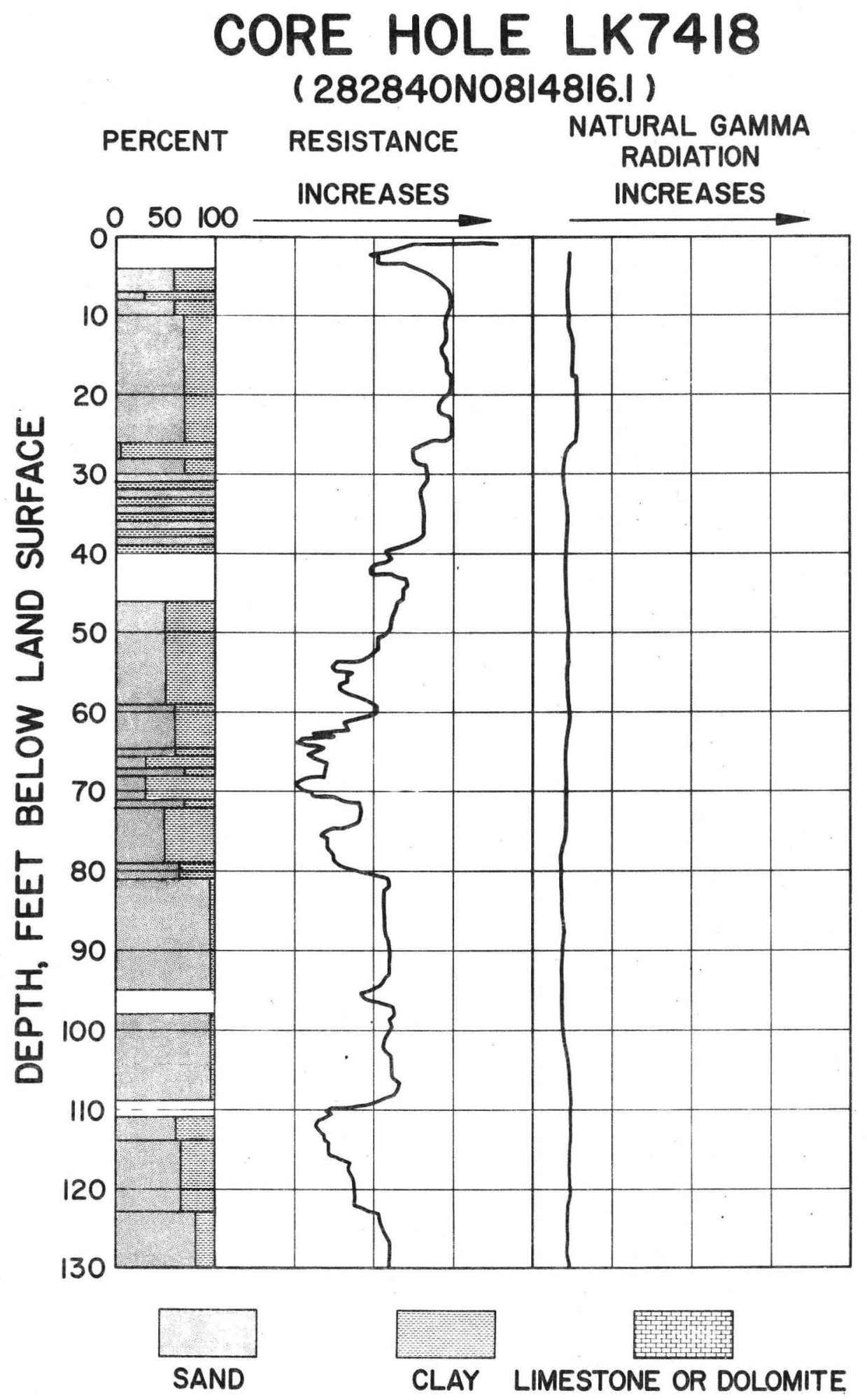




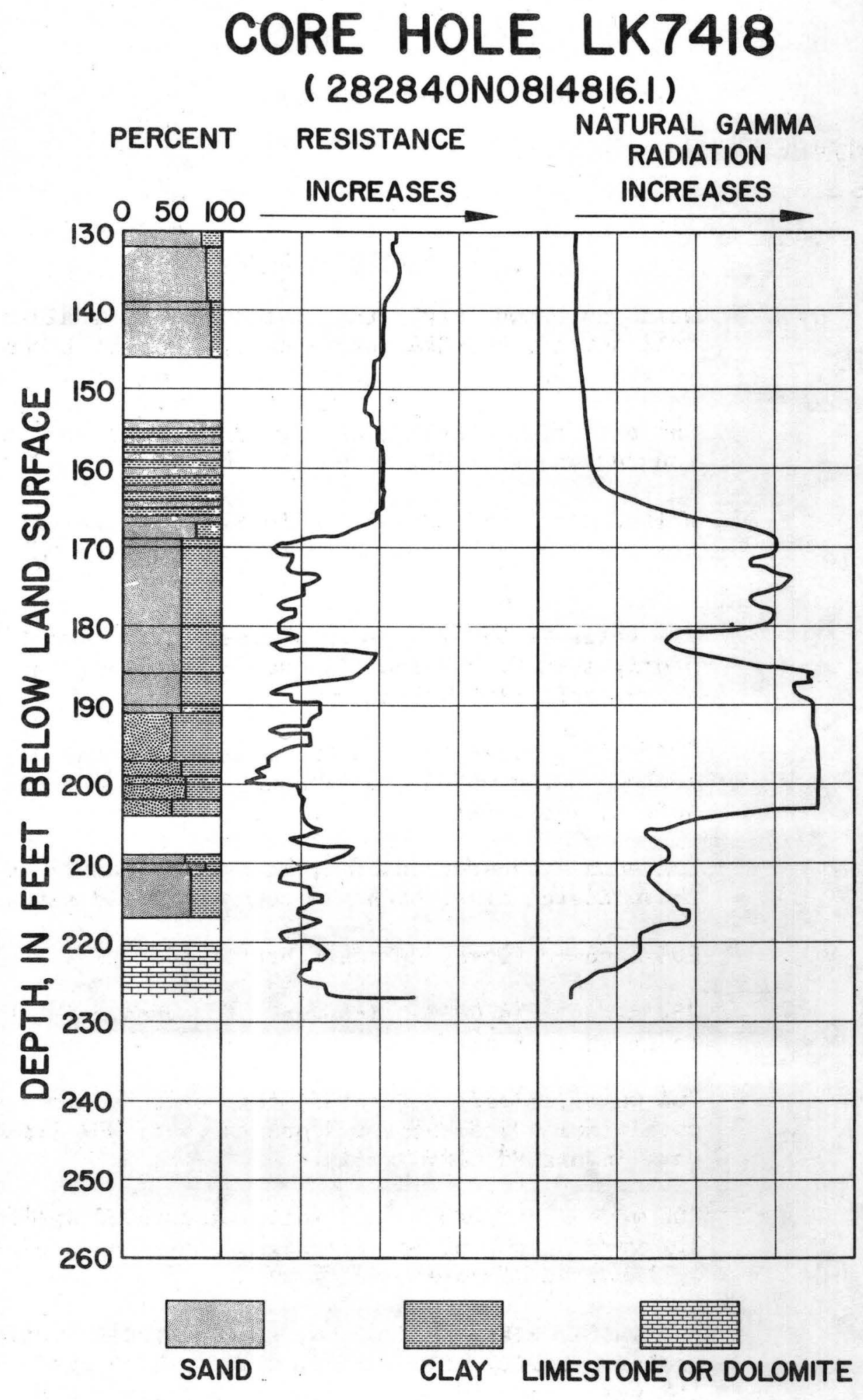


Lake County 282806N0815014.1

DEPTH INTERVAL (feet)

$1.0-3.0$

$3.0-3.5$

$3.5-8.0$

$8 \cdot 0-14.0$

$14.0-15.0$

$15.0-19.0$

$19.0-21.0$

$21.0-23.0$

$23.0-26.0$

$26.0-30.0$
LITHOLOGY

\section{Post Miocene Rocks}

White to brown, clear to frosted, medium-grained, well sorted, rounded quartz sand; trace of brown to gray clay.

White to tan, medium-grained, fairly we11 sorted, rounded quartz sand; trace of tan clay.

White, clear to frosted, medium-grained, fairly well sorted, sub-angular quartz sand; trace of heavy minerals.

$85 \%$ white to brown, clear to frosted, medium-grained, poorly sorted, sub-rounded quartz sand; $15 \%$ dark brown, soft clay matrix.

$70 \%$ white, clear to frosted, medium-grained, poorly sorted, sub-rounded quartz sand; $30 \%$ light brown, soft clay matrix.

$80 \%$ sand as above; $20 \%$ tan, indurated, fair1y we11 consolidated clay; abundant coarse-grained sand.

$80 \%$ sand as above; $20 \%$ dark brown, soft clay.

$75 \%$ sand as $14.0-15.0$ interval; $25 \%$ very dark brown to gray, soft clay.

$70 \%$ white, clear to frosted, coarse-to medium-grained, poor1y sorted, sub-rounded quartz sand; $30 \%$ light tan, indurated clay matrix.

$90 \%$ very light tan to off-white, indurated siltstone $10 \%$ very light tan to off-white, very fine-grained, well sorted, angular quartz sand.

$85 \%$ white, clear to frosted, very coarse-to coarsegrained, fairly well sorted, well rounded quartz sand; $15 \%$ very light tan, soft clay with silty areas throughout; trace of heavy minerals. 
$31.0-39.0$

$39.0-54.5$

$54 \cdot 5-55.0$

$55.0-57.0$

$57.0-59.0$

$59.0-61.0$

$61.0-61.5$

$61.5-64.0$

$64 \cdot 0-67.0$

$67.0-69.0$

$69.0-71.0$

$71.0-72.0$
$85 \%$ white, clear, fine-grained, well sorted, angular quartz sand; $15 \%$ very light gray to offwhite, poorly consolidated, silty clay matrix; scattered coarse-to very coarse-grained sand.

$60 \%$ white, clear, fine-grained, well sorted, angular quartz sand; $40 \%$ off white, silty, soft clay matrix; trace of heavy minerals.

As above but color is very pale greenish gray.

$98 \%$ very pale greenish gray, soft clay matrix; $2 \%$ white, clear, fine-to very fine-grained, well sorted, angular quartz sand; trace of heavy minerals.

No sample.

$80 \%$ very pale greenish gray, indurated, silty clay matrix; $20 \%$ sand as 55.0-57.0 interval; trace of heavy minerals.

$70 \%$ white, clear, fine grained, we11 sorted, angular quartz sand; $25 \%$ white to very pale green, indurated clay matrix; $5 \%$ pisolitic silica; trace of heavy minerals.

Sand as above occuring as 1/8-inch wide bands in a pale, green, soft, waxy clay matrix.

No sample.

\section{Rocks of Miocene Age}

Off-white, soft to indurated, powdery clay.

Very light gray and dull yellow mottled, soft, powdery clay.

\section{Rocks of Eocene Age(?)}

Drill bit fell into cavity; circulation lost, could not be re-established. 


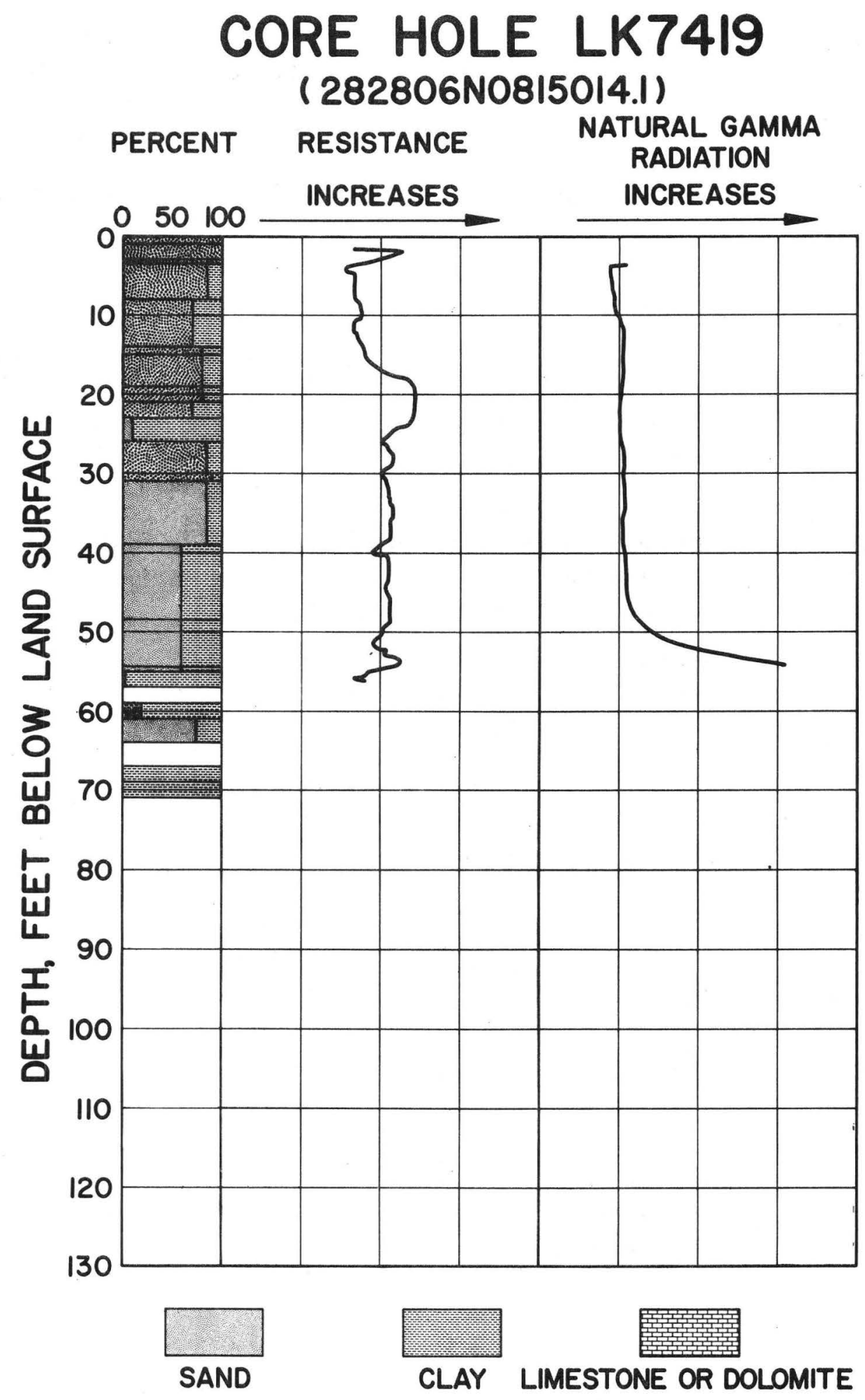


Lake County 282608 N0814524.1

DEPTH INTERVAL (feet)

$0.0-2.0$

$2.0-4.0$

$4 \cdot 0-6.0$

$6.0-8.5$

$8 \cdot 5-13.0$

$13.0-15.0$

$15.0-15.5$

$15 \cdot 5-23.0$

$23.0-24.5$

$24.0-25.5$

$25.5-26.5$

$26.5-29.0$

$29.0-49.0$

\section{LITHOLOGY}

\section{Post Miocene Rocks}

Medium brown, coarse-to medium-grained, stained, poorly sorted, sub-rounded sand.

Tan, stained, coarse-to medium-grained, sub-rounded sand.

No sample.

$50 \%$ bright orange and yellow, stained, coarse-to very coarse-grained, well sorted, rounded sand; $50 \%$ brick red, light to medium tan and dull yellow mottled, indurated, crumbly clay matrix.

No sample.

$85 \%$ light gray to yellow, clear to stained, coarseto very coarse-grained, poorly sorted, rounded sand; $15 \%$ light tan, indurated, crumbly clay matrix.

$60 \%$ white, frosted, coarse-to very coarse-grained, poorly sorted, rounded sand; $40 \%$ white, indurated clay matrix.

No sample.

Sand as 15.0-15.5 interval with just enough very light tan clay to bind sand very loosely.

$75 \%$ sand as $15.0-15.5$ interval but is fairly well sorted; $25 \%$ white, soft clay matrix.

$70 \%$ white to light brown, clear to stained, medium-to very coarse-grained sand; $30 \%$ light brown, light tan and orange mottled, soft, crumbly clay matrix.

No sample.

$70 \%$ white, clear to frosted, fine-to very coarsegrained, angular to rounded, silty sand; $30 \%$ white, soft clay matrix; trace of heavy minerals. 


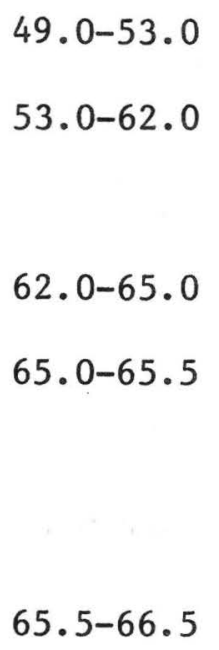

$66.5-66.7$

$66.7-67.5$

$67.5-71.0$

$71.0-71.5$

$71.5-79.1$

No sample.

\section{$\underline{\text { Rocks of Eocene Age(?) }}$}

$79.1-102.4$

Circulation lost at 79.1 feet; could not be re-established. 


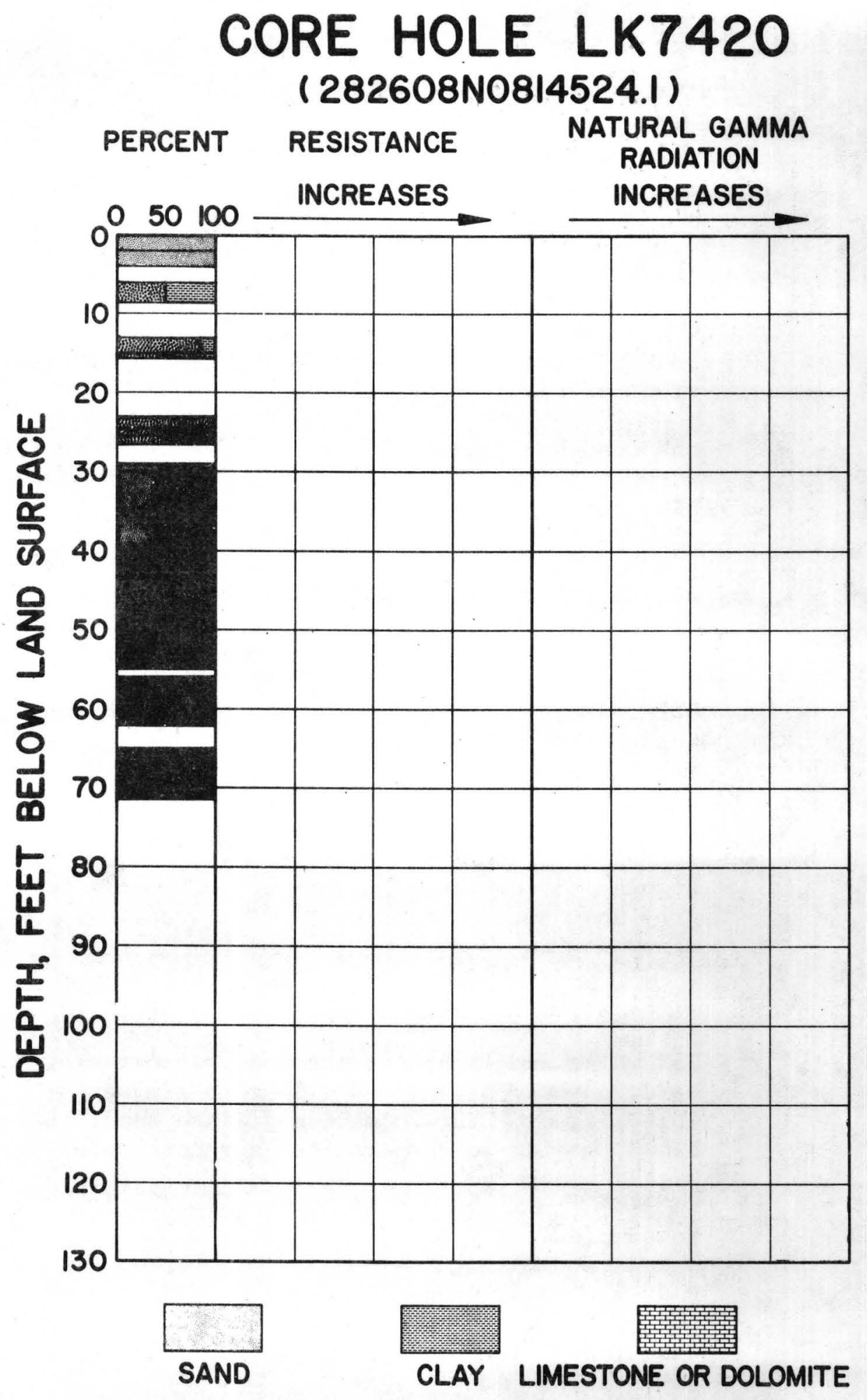


Lake County 282455N0814837.1

DEPTH INTERVAL (feet)

$2 \cdot 5-14.0$

$14.0-17.5$

$17.5-20.0$

$20.0-36.0$

$36.0-53.0$

$53.0-65.0$

\section{LITHOLOGY}

\section{Post Miocene Rocks}

Light gray to light brown, clear, very-coarse to medium-grained, poorly sorted, sub-rounded quartz sand; trace of light gray to light brown, soft clay; a few small quartz pebbles.

$60 \%$ white, clear, fine-grained, fairly well sorted, sub-angular quartz sand; $40 \%$ cream, indurated clay matrix; scattered medium-to coarse-grained sand.

$60 \%$ white, clear, very coarse-to medium-grained, we11-rounded, poorly sorted quartz sand; $40 \%$ white to cream, fairly well indurated clay matrix.

$65 \%$ white to light gray, clear to frosted, fineto very coarse-grained, poorly sorted, sub-angular to wel1-rounded quartz sand; $35 \%$ tan, fairly well indurated clay matrix.

$60 \%$ white, clear to frosted, fine-to very coarsegrained, poorly sorted, sub-angular to well-rounded quartz sand; $40 \%$ cream, fairly well indurated clay matrix.

$50 \%$ white, clear, fine-grained, well sorted, angular quartz sand; $40 \%$ light tan, fairly well indurated clay matrix; $10 \%$ coarse-to very coarse-grained, white to light gray, frosted, we11-rounded quartz sand in bands scattered throughout interval.

\section{Rocks of Miocene Age}

$55 \%$ white, clear, fine-grained, poorly sorted, subangular quartz sand; $45 \%$ dark gray and tan mottled and streaked, soft clay matrix. 


\section{Rocks of Eocene Age}

$65.0-71.0$

$75 \%$ very light gray, indurated highly fossiliferous, chalky, clayey limestone; $20 \%$ clay which coats the limestone; $5 \%$ light gray, frosted, very coarse-grained, we11-rounded quartz sand; contains Sphaerogypsina globula (Reuss), Reussella sculptilis (Cushman), and Cibicides mississippiensis ocalanus (Cushman). 


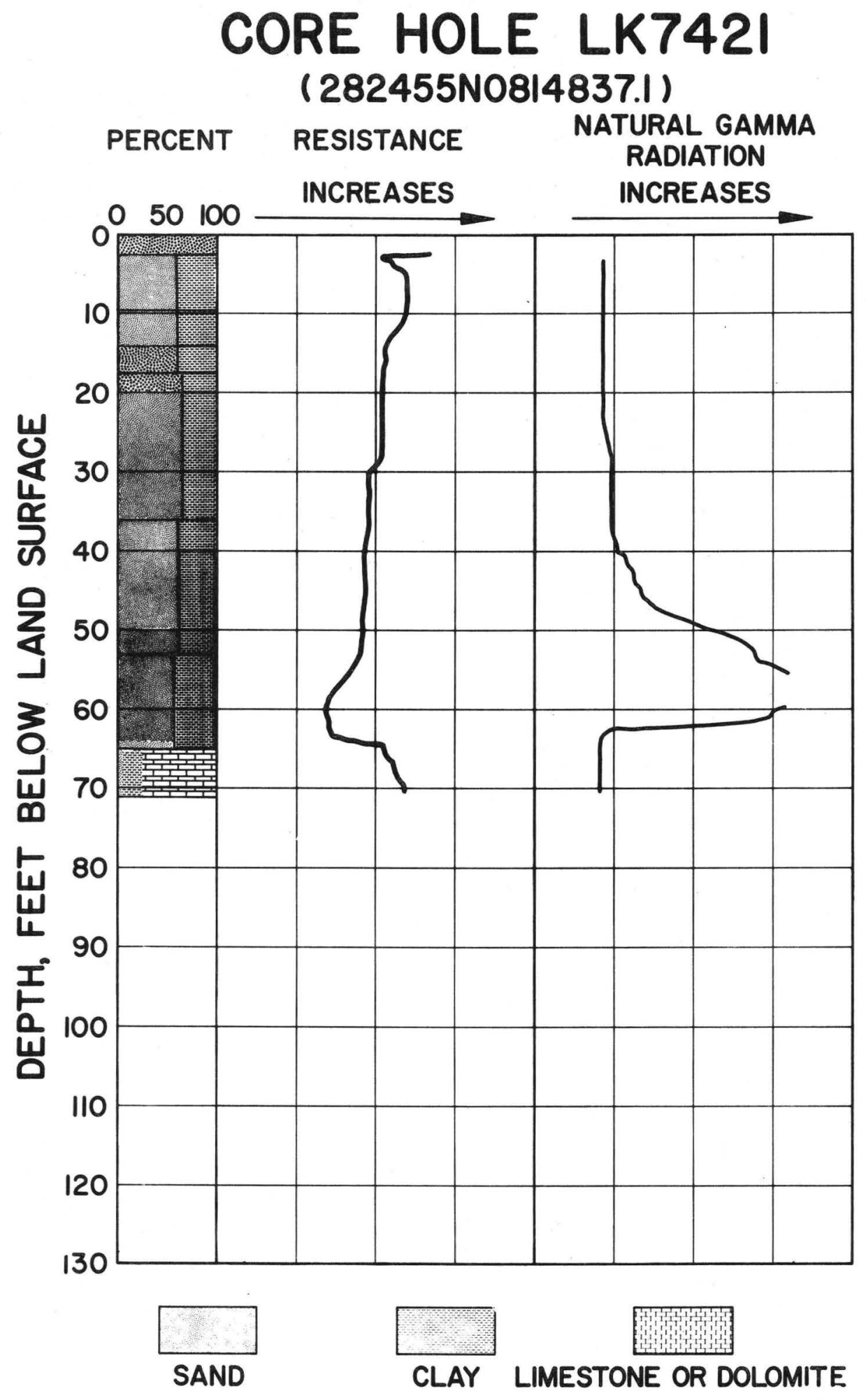


Lake County $\quad$ 282443N0814602.1

DEPTH INTERVAL (feet

$0.0-1.0$

$1.0-3.0$

$3.0-10.5$

$10.5-11.0$

$11.0-11.5$

$11 \cdot 5-12.0$

$12.0-12.5$

$12 \cdot 5-14.5$

$14 \cdot 5-15.5$

$15 \cdot 5-18.0$

$18.0-19.5$

$19.5-20.5$

$20.5-26.0$

\section{LITHOLOGY}

\section{Post Miocene Rocks}

95\% white and brown, clear to stained, medium-to very coarse-grained, sub-angular to rounded sand; $5 \%$ medium brown, crumbly clay matrix.

White to light brown, clear to stained, coarse-to medium-grained, sub-rounded sand; trace of very dark to light gray, soft clay.

No sample.

95\% white and brown, clear to stained, coarse-to medium-grained, fairly well sorted, sub-rounded sand; 5\% medium brown, indurated, crumbly clay.

$60 \%$ sand as above; $40 \%$ very dark gray, soft crumbly clay.

$70 \%$ sand as $10.5-11.0$ interval; $30 \%$ light and medium brown, soft clay matrix.

$65 \%$ light brown, clear to frosted, medium-grained, fairly well sorted, sub-rounded sand; $30 \%$ medium brown, indurated clay matrix; 5\% coarse-to very coarse-grained sand.

$75 \%$ sand as above; $25 \%$ medium brown, soft clay.

No sample.

$80 \%$ sand as $12.0-12.5$ interval; $20 \%$ light brown, indurated, crumbly clay matrix.

$70 \%$ white, clear to frosted, fine-to medium-grained, angular to sub-rounded sand; $30 \%$ medium brown, indurated, clay matrix with thin (1/16 to $1 / 4-i n c h)$ bands of dark gray clay.

No sample.

$60 \%$ sand as $18.0-19.5$ interval; $40 \%$ tan, indurated clay matrix with minor medium brown and dark gray mottling and streaking. 
$26.0-28.5$

28. 5-30.2

$30.2-32.5$

$32.5-34.5$

34. 5-36.5

$36.5-38.5$

$38.5-39.5$

$39.5-41.5$

41. 5-48.5

48.5-50.0

50.0-53.5

53.5-55.5

$55.5-58.5$

58.5-60.5

$60.5-61.5$

61.5-68.5
No sample.

$70 \%$ sand as $20.5-26.0$ interval; $30 \%$ medium brown and tan mottled, indurated clay matrix.

$70 \%$ sand as $20.5-26.0$ interval; $30 \%$ medium brown and light brownish gray banded, indurated clay matrix; bands are 1/4-inch wide.

No sample.

$80 \%$ white, clear to frosted, medium-to coarse-grained, sub-rounded to rounded sand; $20 \%$ tan and medium brown mottled, indurated, crumbly clay matrix.

$70 \%$ white, clear to frosted, medium-grained, we11 sorted, sub-angular to sub-rounded sand; $30 \%$ tan, soft, crumbly, slightly silty clay matrix.

$80 \%$ white to light gray, frosted, coarse-to very coarse-grained, sub-rounded to rounded sand; $20 \%$ tan, indurated clay matrix.

$80 \%$ sand as above, $20 \%$ dark brown and light tan banded, soft clay matrix.

No sample.

$80 \%$ white to light gray, clear to frosted, mediumto very coarse-grained, sub-rounded to rounded sand; $20 \%$ light brown and tan mottled, indurated, crumbly clay matrix.

No sample.

$75 \%$ sand as $48.5-50.0$ interval but mostly mediumgrained; $25 \%$ tan, indurated clay matrix.

No sample.

$80 \%$ sand as $48.5-50.0$ interval but mostly coarseto very coarse-grained; $20 \%$ light brown, soft clay matrix.

$50 \%$ light tan soft clay matrix; $45 \%$ white, clear to frosted, very fine-to fine-grained, angular, we11 sorted sand; $5 \%$ coarse-to very coarse-grained sand; trace of heavy minerals.

No sample. 
$68.5-70.5$

$70.5-71.5$

$71.5-73.0$

$73.0-74.5$

$74.5-78.5$

$78.5-83.5$

$83.5-84.0$

$84.0-87.5$

$87.5-88.5$

$88.5-89.5$

$89.5-96.0$

$96.0-96.8$
$50 \%$ sand and $50 \%$ clay as $60.5-61.5$ interval; trace of heavy minerals and pyrite.

$40 \%$ light tan and light gray mottled, soft clay matrix; $35 \%$ sand as $60.5-61.5$ interval; $25 \%$ coarseto very coarse-grained sand.

$50 \%$ sand as $60.5-61.5$ interva1; $40 \%$ light tan, soft clay matrix; $10 \%$ coarse-to very coarse-grained sand; trace of heavy minerals.

$40 \%$ coarse-to very coarse-grained sand; $35 \% 1$ ight tan, clay matrix; $25 \%$ sand as $60.5-61.5$ interval.

No sample.

$60 \%$ white, clear to frosted, very fine-to finegrained, silty, angular, well sorted sand; $40 \%$ very light tan, soft clay matrix; trace of coarse-grained sand and heavy minerals.

$50 \%$ sand as $78.5-83.5$ interval; $40 \%$ very light gray, indurated, crumbly clay matrix; $10 \%$ coarse-to very coarse-grained sand; trace of heavy minerals.

No sample.

$60 \%$ sand as $78.5-83.5$ interval; $40 \%$ light tan, indurated, crumbly clay matrix; trace of heavy minerals.

$60 \%$ white to light gray, clear, medium-grained, fairly well sorted, sub-rounded sand; $35 \%$ light tan, light gray and light green mottled, indurated, crumbly clay; $5 \%$ light gray, clear, rounded, coarse-grained sand; trace of heavy minerals, pyrite and pisolitic silica.

No sample.

\section{Rocks of Eocene Age}

Dark gray and greenish gray weathered limestone. 


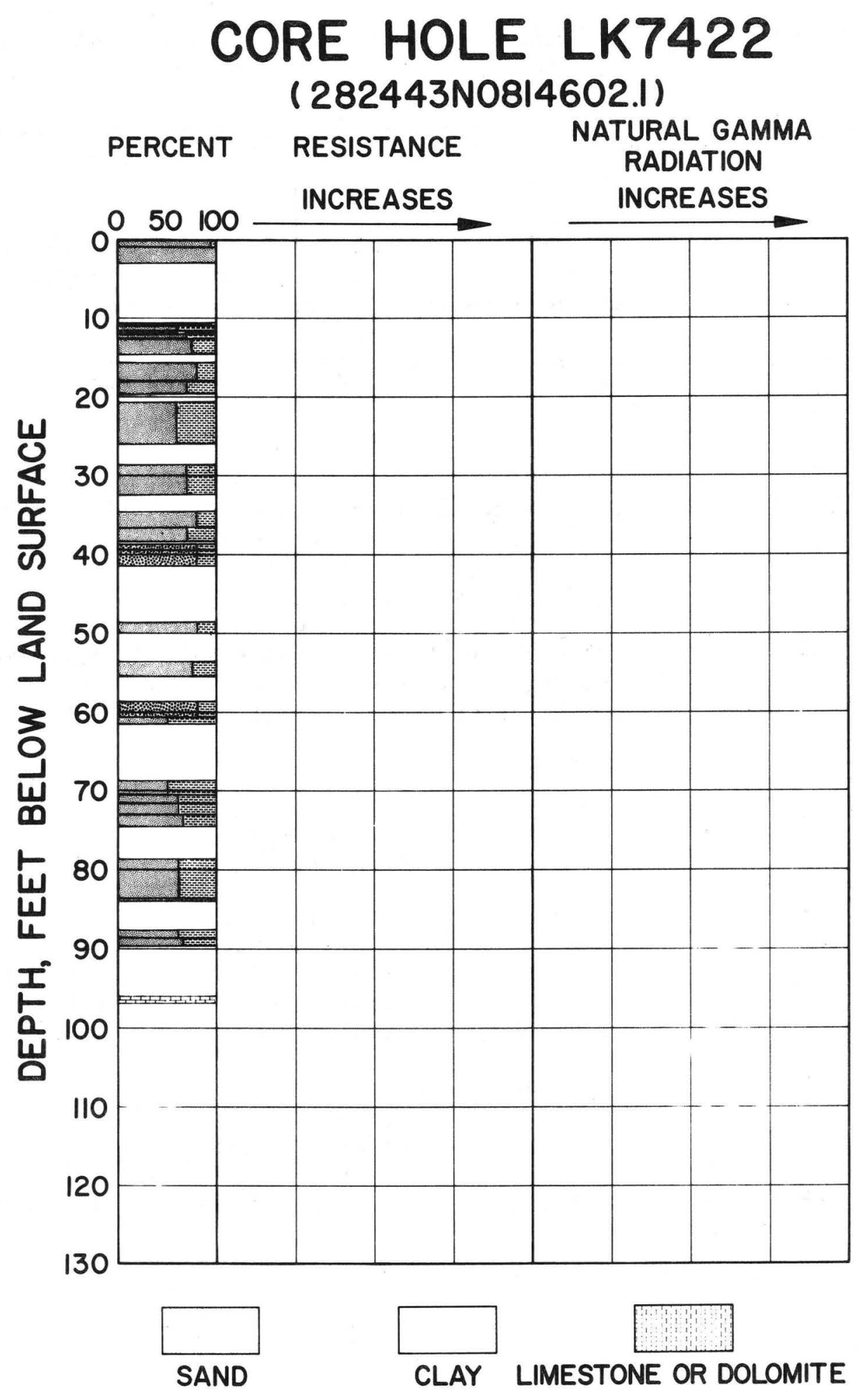


LK7424

Lake County 282522N0814443.1

DEPTH INTERVAL

(feet)

$0.0-6.0$

$6.0-7.0$

$7.0-8.5$

$8.5-10.5$

$10.5-11.0$

$11.0-11.5$

$11.5-12.0$

$12.0-20.0$

$20.0-22.0$

$22.0-35.0$

$35.0-39.0$
LITHOLOGY

\section{Post Miocene Rocks}

No sample.

$65 \%$ light brown, fine-to coarse-grained, angular to rounded quartz sand; $35 \%$ medium brown, indurated clay matrix.

$50 \%$ light tan, frosted, medium-grained, fairly well sorted, sub-rounded quartz sand; $50 \%$ light tan and light brown mottled, indurated clay matrix with minor blue mottling.

$55 \%$ sand as $7.0-8.5$ interval; $45 \%$ tan, indurated clay matrix.

$70 \%$ sand as $7.0-8.5$ interval; $30 \%$ light brown, soft clay matrix.

$75 \%$ white to light brown, frosted, medium-grained, fairly well sorted, sub-rounded quartz sand; $25 \%$ brown, soft clay matrix.

$70 \%$ white to brown, clear to stained, medium-grained, fairly well sorted, sub-angular to sub-rounded quartz sand; 30\% black, light and dark brown mottled, soft crumbly clay matrix.

No sample.

95\% light tan, stained, medium-grained, fairly well sorted, sub-angular to sub-rounded quartz sand; $5 \%$ tan, soft clay matrix.

No sample.

$85 \%$ light tan, stained, fine-grained, we11 sorted, angular quartz sand; $15 \%$ tan, soft clay matrix; trace of medium muscovite flakes and medium-grained sand. 


\begin{tabular}{|c|c|}
\hline $39.0-42.0$ & $\begin{array}{l}70 \% \text { white, clear to frosted, fine-grained, we } 11 \\
\text { sorted, angular quartz sand; } 20 \% \text { light tan, soft } \\
\text { silty clay matrix; } 10 \% \text { white, frosted, coarse-to } \\
\text { very coarse-grained, rounded sand; trace of } \\
\text { medium muscovite flakes. }\end{array}$ \\
\hline $42.0-45.0$ & No sample. \\
\hline $45.0-50.0$ & $\begin{array}{l}80 \% \text { sand as } 39.0-42.0 \text { interval; } 20 \% \text { light tan, indurated } \\
\text { clay matrix; trace of muscovite flakes. }\end{array}$ \\
\hline $50.0-55.0$ & No sample. \\
\hline $55.0-73.0$ & $\begin{array}{l}60 \% \text { light gray, frosted, fine-grained, well sorted, } \\
\text { angular quartz sand; } 40 \% \text { medium greenish gray, soft } \\
\text { clay matrix; slight1y silty. }\end{array}$ \\
\hline $73.0-76.0$ & No sample. \\
\hline $76.0-80.0$ & $\begin{array}{l}80 \% \text { white, frosted, fine-to very fine-grained, angular, } \\
\text { silty, very well sorted quartz sand; } 20 \% \text { light brown, } \\
\text { indurated clay matrix with a slight gray tint; trace } \\
\text { of coarse-to very coarse-grained sand. }\end{array}$ \\
\hline $80.0-81.0$ & $\begin{array}{l}75 \% \text { sand as above; } 25 \% \text { clay as above with dark gray } \\
\text { mottling. }\end{array}$ \\
\hline $81.0-85.0$ & $\begin{array}{l}65 \% \text { sand as } 76.0-80.0 \text { interva1; } 35 \% \text { clay as } 80.0-81.0 \\
\text { interva1; contains Sphaerogypsina globula (Reuss). }\end{array}$ \\
\hline & Rocks of Eocene Age \\
\hline $85.0-103.0$ & $\begin{array}{l}\text { Light gray, microcrystalline, indurated, porous } \\
\text { limestone with scattered small foraminifera; highly } \\
\text { weathered. }\end{array}$ \\
\hline
\end{tabular}




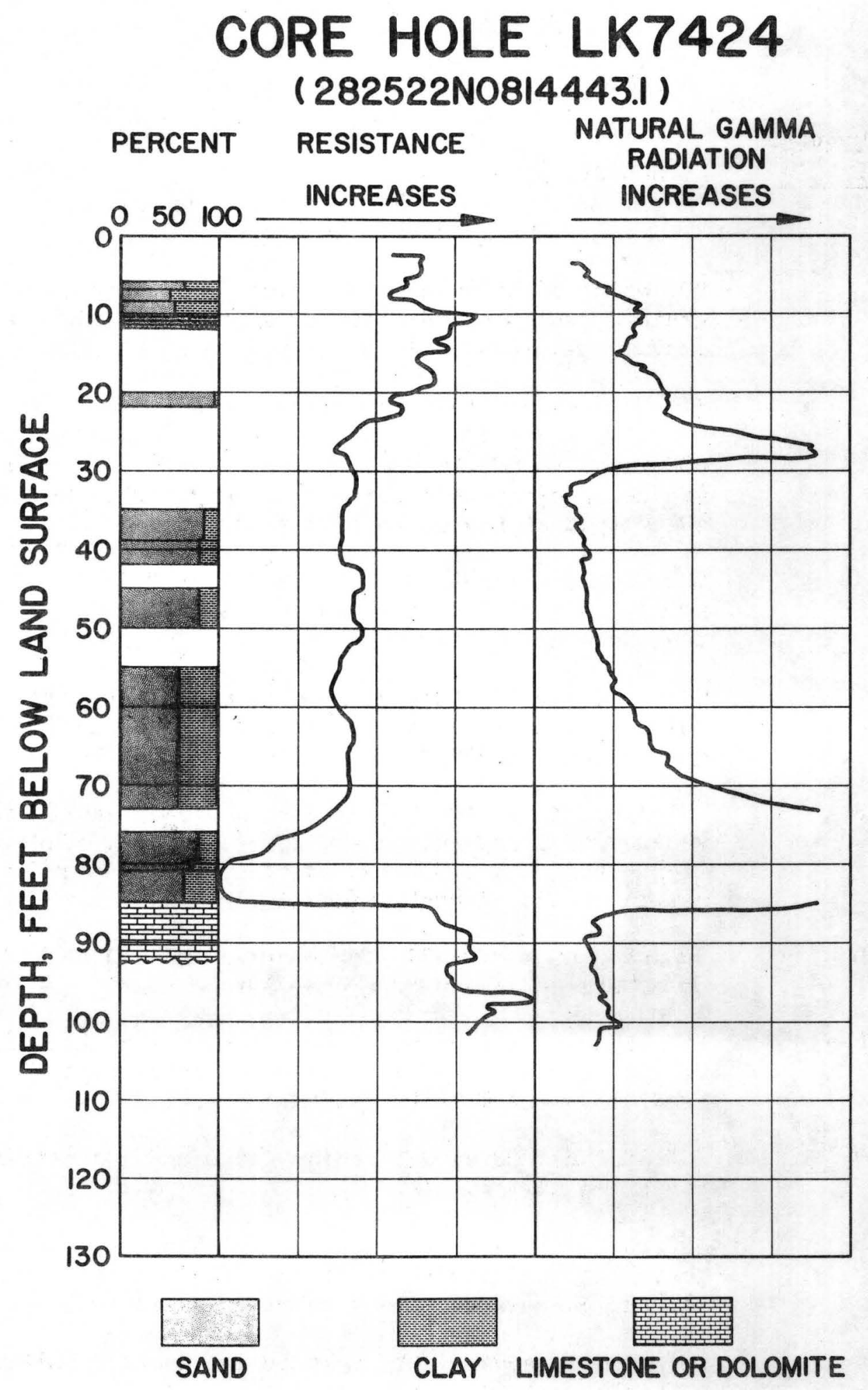


LK7425

Lake County 282318N0815440.1

DEPTH INTERVAL (feet)

$1.0-2 \cdot 0$

$2 \cdot 0-4 \cdot 0$

$4.0-9.0$

$9.0-11.5$

$11.5-17.5$

$17 \cdot 5-19.0$

$19.0-25.0$

$25.0-26.0$

$26.0-27.0$

$27.0-30.0$
LITHOLOGY

\section{Post Miocene Rocks}

$90 \%$ white to brownish gray, clear to stained, mediumgrained, well sorted, rounded quartz sand; $10 \%$ dark gray, very organic, loose clay matrix.

Sand as above; trace of medium brown clay.

$60 \%$ white to medium brown, clear to stained, mediumgrained, fairly well sorted, sub-rounded quartz sand; $40 \%$ very dark brown, soft clay matrix.

$60 \%$ white to light tan, frosted, medium-grained, fairly well sorted, sub-rounded quartz sand; $40 \%$ tan, soft clay matrix.

White, clear to frosted, fine-to medium-grained, fairly well sorted, sub-angular to sub-rounded quartz sand; trace of heavy minerals.

55\% light tan, frosted, fine-to medium-grained, fairly well sorted, angular to sub-rounded quartz sand; $45 \%$ light brown and light tan mottled, soft, sticky clay matrix; trace of heavy minerals.

$55 \%$ sand as above; $45 \%$ light brown and tan mottled, soft, sticky clay matrix; has purple cast.

$65 \%$ 1ight tan, frosted, fine-to medium-grained, fairly well sorted, sub-angular to sub-rounded quartz sand; $35 \%$ medium brown, soft clay matrix.

$65 \%$ sand as above; $35 \%$ medium brown and tan mottled, indurated clay matrix.

$60 \%$ white, frosted, fine-to medium-grained, angular to sub-rounded quartz sand; $35 \% \mathrm{tan}$, indurated clay matrix; $5 \%$ coarse-to very coarse-grained sand.

$70 \%$ sand as above; $30 \%$ light to medium tan, banded, soft clay matrix. 
$30.0-32.0$

$32.0-37.5$

$37.5-44.0$

$44 \cdot 0-47.0$
$60 \%$ sand as $26.0-27.0$ interval; $40 \%$ light tan, soft, silty clay matrix with white, very hard clay fragments at the base of this interval.

$65 \%$ light gray to white, clear to frosted, mediumto fine-grained, fairly well sorted, angular to subrounded quartz sand; $35 \%$ dull yellow and tan mottled, indurated to soft, clay matrix; a few fragments of white, microcrystalline, silicified limestone; a few thin (1/4-inch) bands of pure, medium brown clay.

\section{Rocks of Eocene Age}

$75 \%$ white to light gray, indurated, microcrystalline, porous, silicified, limestone fragments; $20 \%$ light brown, soft, lightly calcareous clay matrix; $5 \%$ sand as above; trace of relic fossil material.

Cavity. 


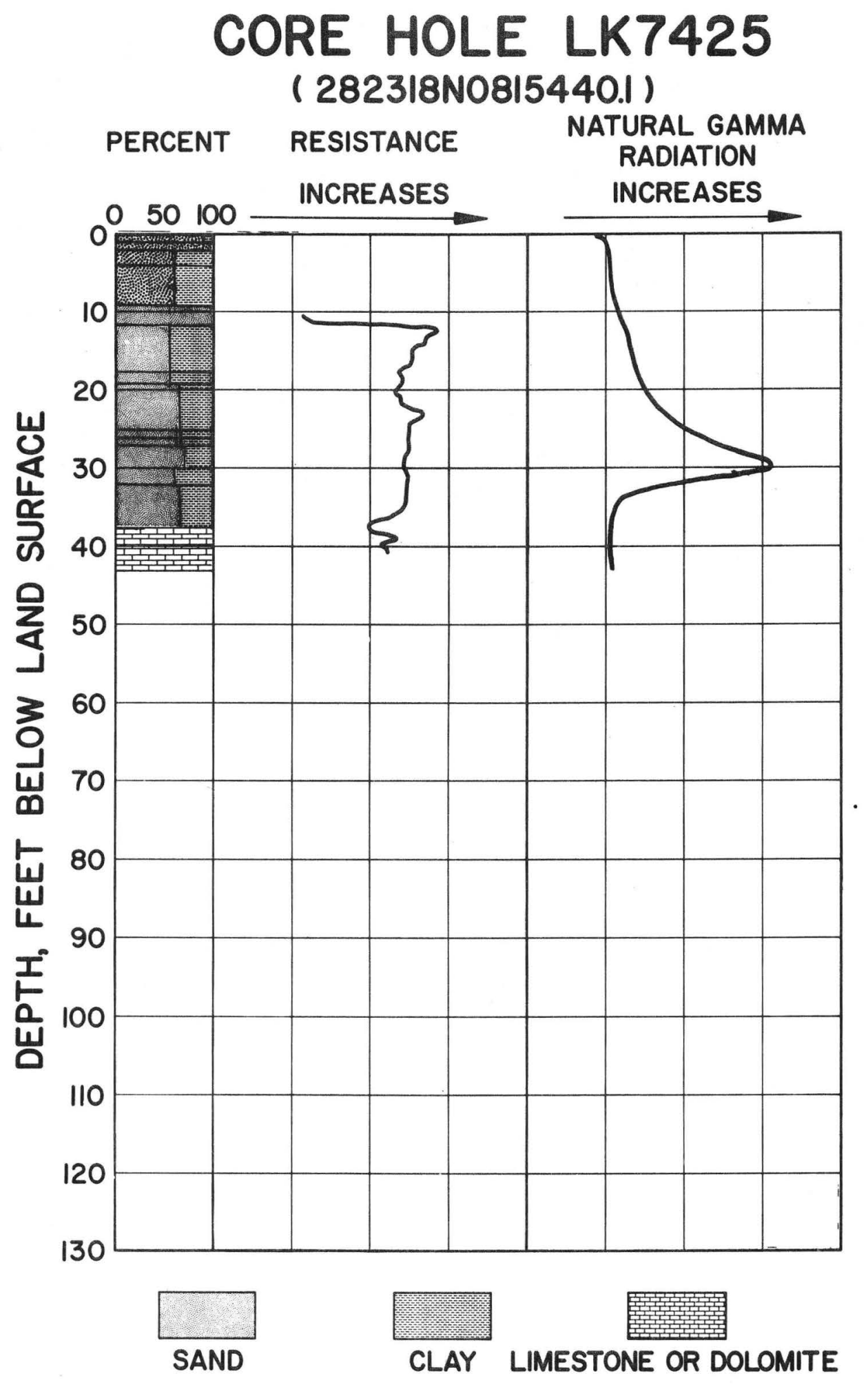


Lake County 282348N0814434.1

DEPTH INTERVAL (feet)

$7.0-8.0$

$8 \cdot 0-12.7$

$12 \cdot 7-13 \cdot 0$

$13 \cdot 0-16.5$

$16.5-18.5$

$18.5-20.5$

$20.5-23.0$

$23.0-26.5$

$26.5-28.5$

$28.5-31.5$

$31.5 \cdot 33.0$

\section{LITHOLOGY}

\section{Post Miocene Rocks}

No sample.

White, frosted, medium-grained, fairly well sorted, sub-rounded sand; trace of white to light tan clay and heavy minerals; abundant coarse-to very coarsegrained sand.

$75 \%$ white to dark brownish gray, clear to frosted, medium-grained, poorly sorted, sub-rounded quartz sand; $25 \%$ very dark brownish gray, soft clay matrix; abundant coarse-to very coarse-grained sand.

No sample.

$70 \%$ white, clear to frosted, medium-grained, poorly sorted, sub-rounded sand; 30\% light brown, indurated clay matrix; abundant coarse-to very coarse-grained sand.

$60 \%$ white, clear to frosted, medium-grained, fairly we11 sorted, sub-rounded sand; 40\% light gray, indurated clay matrix; abundant coarse-to very coarsegrained sand; trace of heavy minerals.

No sample.

$65 \%$ sand and $35 \%$ clay as $13.0-16.5$ interval.

$80 \%$ white, clear to frosted, coarse-grained, we11 sorted, rounded sand; $20 \%$ tan, soft clay matrix; abundant coarse-grained sand.

No sample.

Same as 20.5-23.0 interval.

$75 \%$ white, clear to frosted, coarse-grained, poorly sorted, rounded sand; $25 \%$ off-white, soft clay matrix.

No sample. 


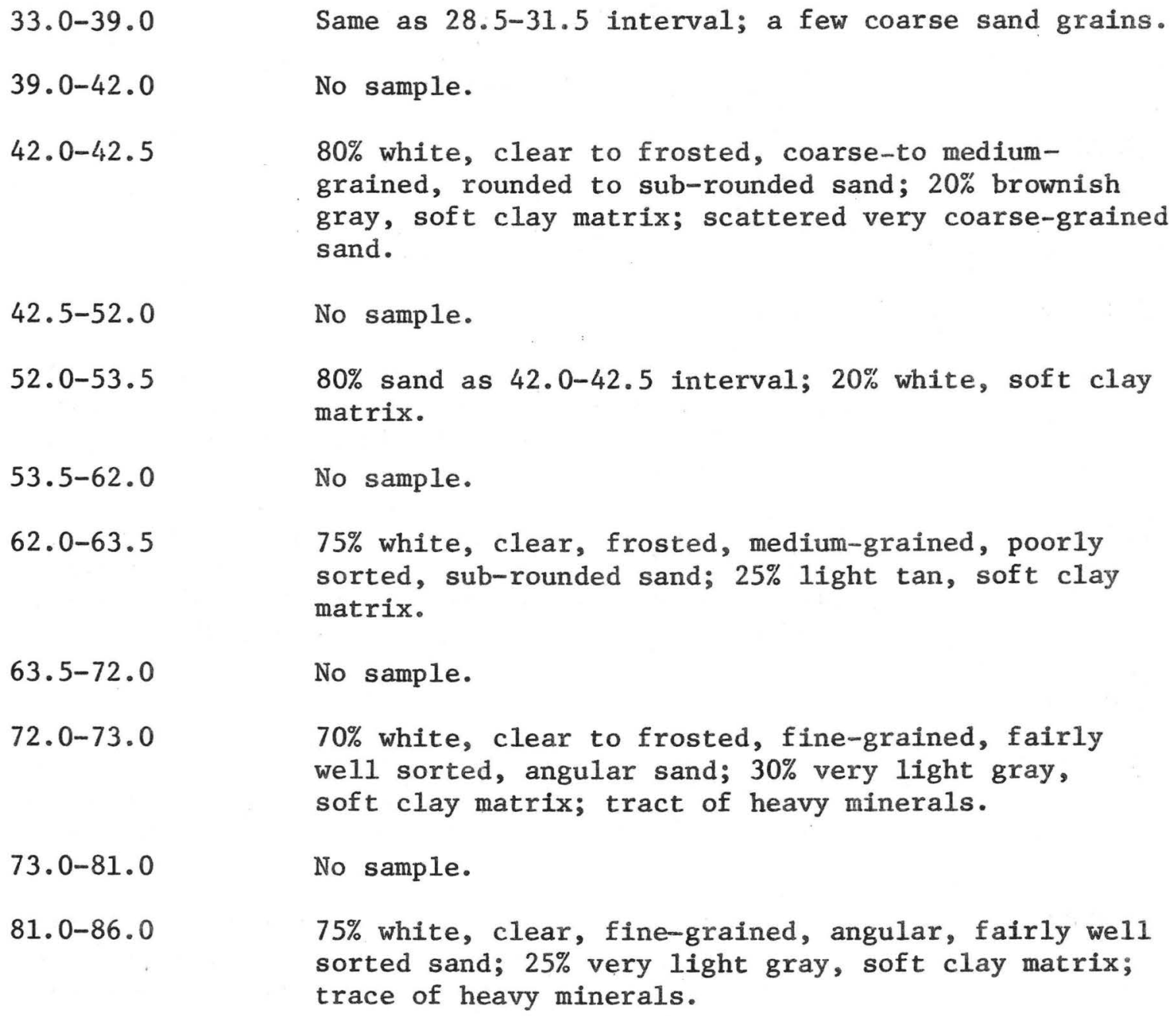

Same as 28.5-31.5 interval; a few coarse sand grains.

No sample.

$80 \%$ white, clear to frosted, coarse-to mediumgrained, rounded to sub-rounded sand; $20 \%$ brownish gray, soft clay matrix; scattered very coarse-grained sand.

No sample.

$80 \%$ sand as $42.0-42.5$ interval; $20 \%$ white, soft clay matrix.

No sample.

$75 \%$ white, clear, frosted, medium-grained, poorly sorted, sub-rounded sand; $25 \%$ light tan, soft clay matrix.

No sample.

$70 \%$ white, clear to frosted, fine-grained, fairly we11 sorted, angular sand; $30 \%$ very light gray, soft clay matrix; tract of heavy minerals.

No sample.

$75 \%$ white, clear, fine-grained, angular, fairly wel1 sorted sand; $25 \%$ very light gray, soft clay matrix; trace of heavy minerals.

\section{Rocks of Miocene Age}

$60 \%$ white, clear, fine-grained, angular, fairly well sorted sand; 40\% greenish gray and light brown banded, soft clay matrix; trace of tan to black phosphate, pyrite and pisolitic silica.

No sample.

\section{Rocks of Eocene Age}

Microcoquina; matrix of microcrystalline, light brown, porous, indurated limestone with $85 \%$ fossiliferous material; trace of sparry calcite replacement and fine-to coarse-grained sand; contains Sphaerogypsina globula (Reuss), Reusse11a sculptilis (Cushman). 


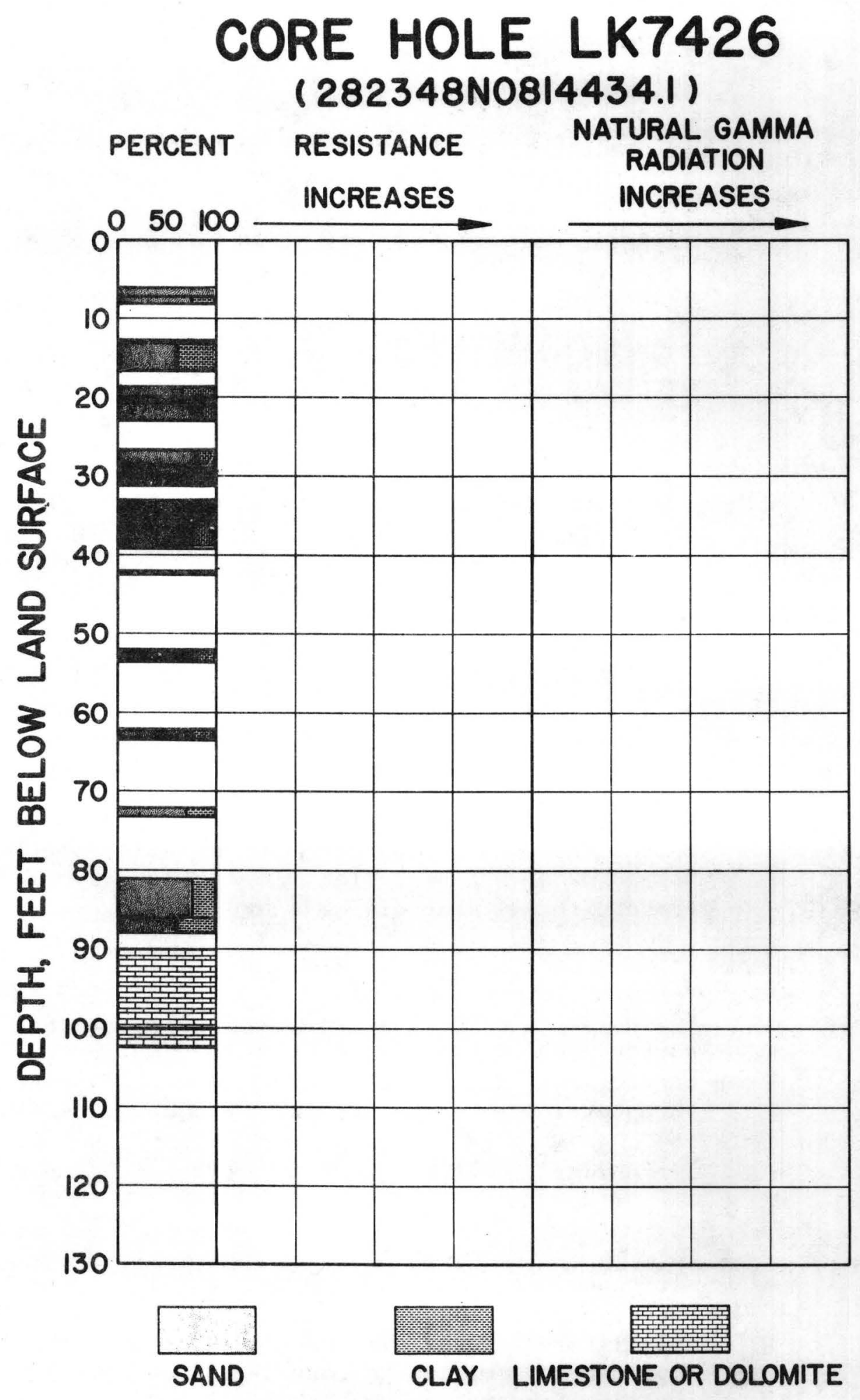


Lake County 282243N0814226.1

DEPTH INTERVAL (feet)

$0.0-1.0$

$1.0-2.0$

$2.0-6.0$

$6.0-8.5$

$8.5-11.7$

$11.7-12.0$

$12 \cdot 0-15.5$

$15 \cdot 5-17.5$

$17.5-19.2$

$19.2-20.2$

$20.2-23.5$

$23.5-30.5$

\section{LITHOLOGY}

\section{$\underline{\text { Post Miocene Rocks }}$}

White to light brown, clear to stained, fine-grained, well sorted, sub-rounded sand.

Tan, fine grained, fairly well sorted, sub-rounded sand.

No sample.

$60 \%$ white, clear to frosted, fine-grained, fairly wel1 sorted, sub-angular quartz sand; $40 \%$ brown and gray mottled, indurated clay matrix; trace of heavy minerals.

$60 \%$ sand as above; $40 \%$ gray, yellow and pink mottled and streaked, indurated clay matrix; trace of heavy minerals.

$60 \%$ white, clear to frosted, fine-grained, fairly well sorted, sub-rounded sand; $40 \%$ very light gray, indurațed clay matrix; trace of heavy minerals.

95\% very light gray, soft clay matrix with bright orange and deep maroon bands; $5 \%$ sand as above; trace of heavy minerals.

No sample.

$60 \%$ white to gray, clear to frosted, medium-grained, fairly well sorted, rounded sand; $40 \%$ red, yellow, and white mottled, soft clay matrix.

White, medium-grained, fairly well sorted, subrounded sand with just enough white clay to bind sand very loosely.

No sample.

White, clear to frosted, medium-grained, fairly well sorted, sub-angular sand with just enough soft clay to bind sand very loosely; trace of heavy minerals. 


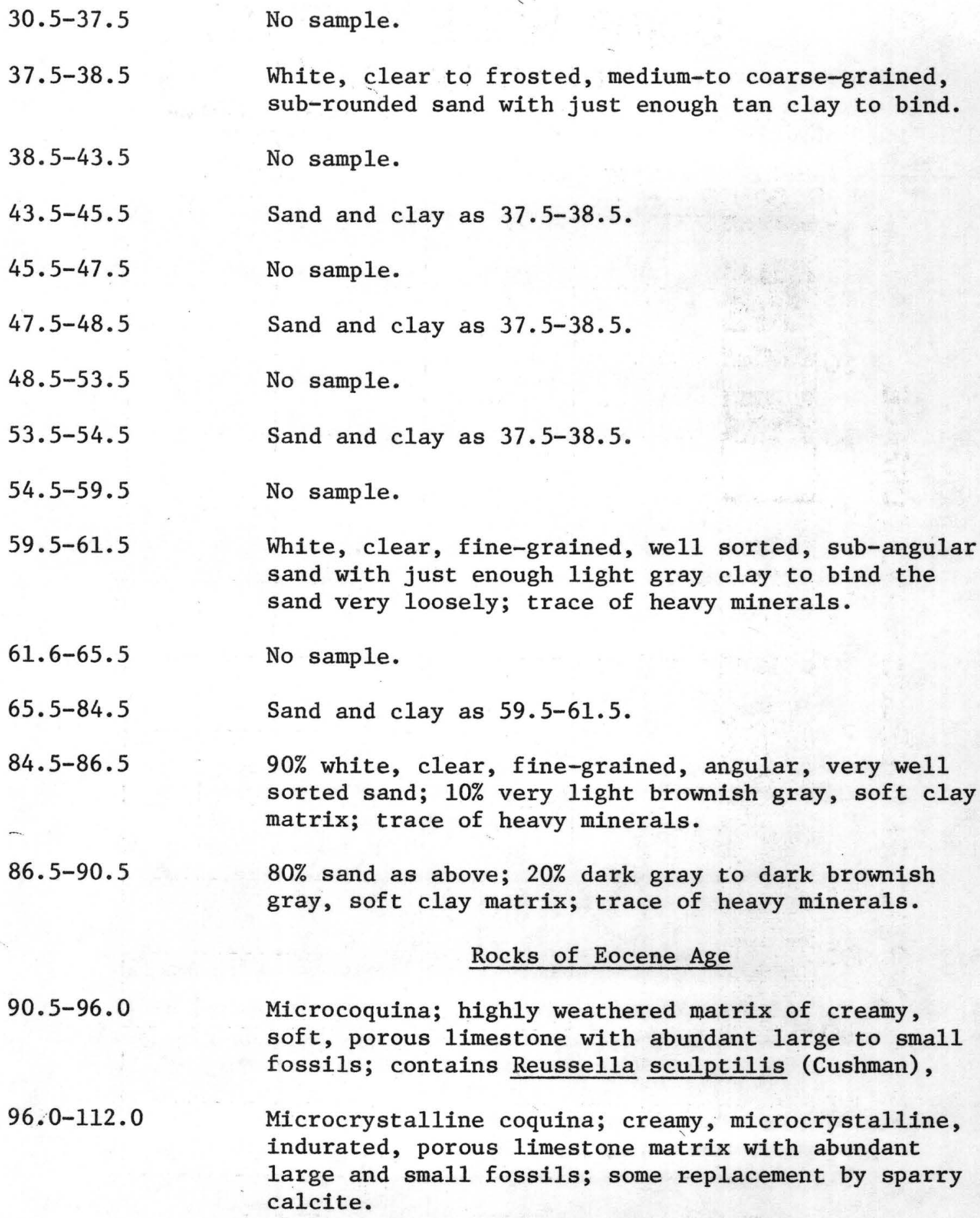




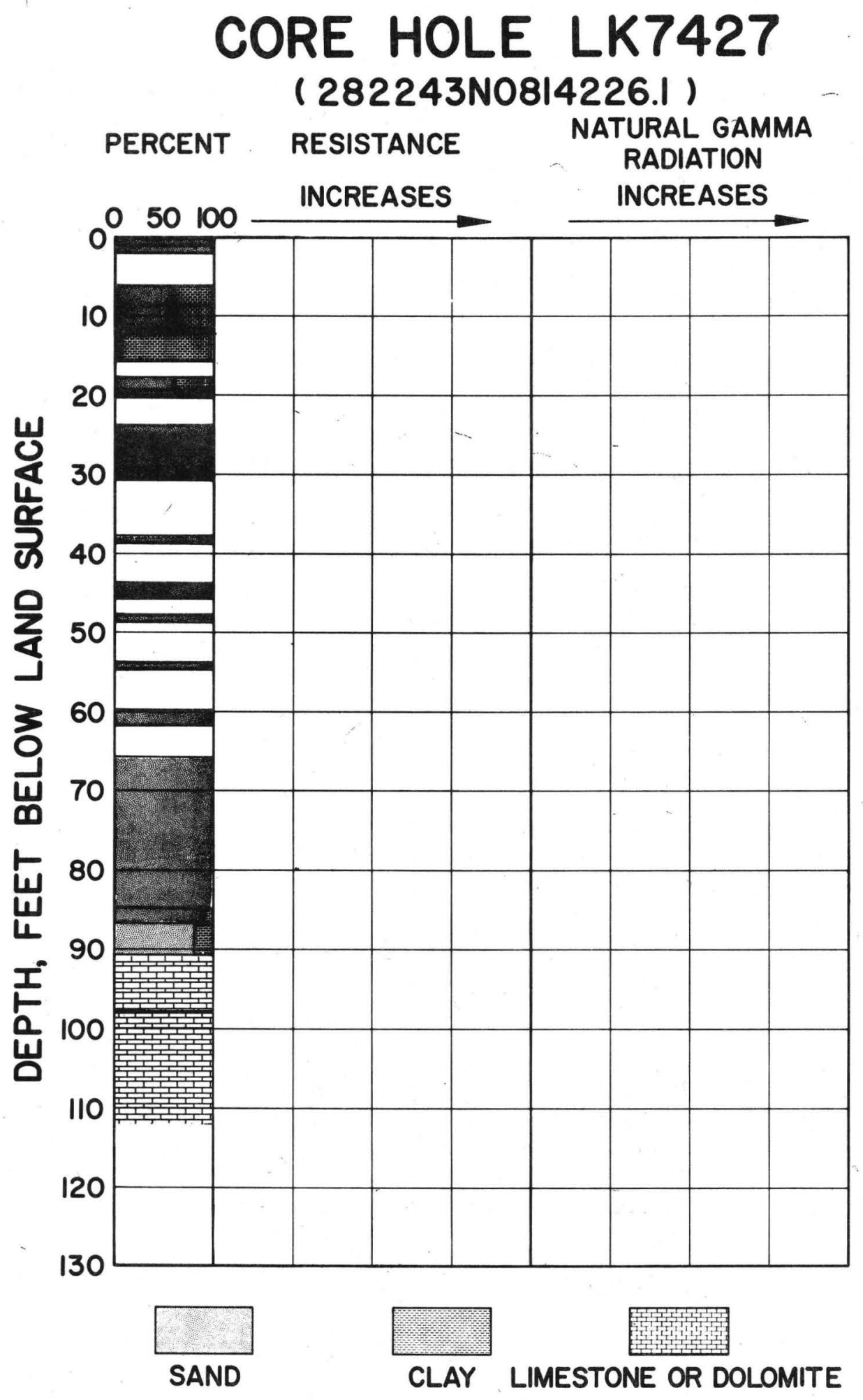


Lake County 282219N0814435.1

DEPTH INTERVAL (feet)

$0.0-1.0$

$1 \cdot 0-2 \cdot 0$

$2.0-3.5$

$3 \cdot 5-6 \cdot 0$

$6.0-7.2$

$7.2-12.5$

$12 \cdot 5-13.5$

$13 \cdot 5-15 \cdot 0$

$15.0-17.5$

$17.5-18.5$

$18.5-19.5$

$19.5-22.7$

$22.7-23.7$

$23.7-25.5$

\section{LITHOLOGY}

\section{Post Miocene Rocks}

$80 \%$ light brown, clear to frosted, coarse-to finegrained, poorly sorted, rounded to angular sand; $20 \%$ brownish gray, indurated clay matrix.

Sand as above; trace of light gray to tan clay.

95\% sand as $0.0-1.0$ interval; $5 \%$ tan clay matrix; a band of very dark gray, soft clay from 3.0 to 3.2 feet.

No sample.

$80 \%$ white, light brown, frosted, coarse-to very coarse-grained, sub-rounded sand; $20 \%$ brown, indurated clay matrix.

No sample.

Same as 6.0-7.2 interval.

$90 \%$ white, milky, coarse-grained, fairly well sorted, rounded sand; 10\% light brown, soft clay matrix.

No sample.

$90 \%$ white, clear to frosted, medium-grained, poorly sorted, sub-rounded sand; $10 \%$ light brown, soft clay matrix; some coarse-grained sand.

90\% light brown, frosted, medium-grained, fairly well sorted, sub-angular sand; $10 \%$ light to dark brown, soft clay matrix; some coarse-grained sand.

No sample.

$80 \%$ white to tan, clear to frosted, medium-grained, fairly well sorted, sub-angular sand; $20 \%$ dark brown, soft clay matrix; scattered coarse-grained sand.

$80 \%$ sand as above; $20 \%$ medium brown, soft clay matrix with some white mottling. 
$25.5-28.5$

$28.5-35.5$

$35.5-36.5$

$36.5-38.5$

$38.5-44.0$

$44.0-48.5$

48.5-50.5

$50.5-56.5$

$56.5-60.5$

$60.5-64.5$

$64.5-68.5$

$68.5-72.5$

$72.5-79.0$
No sample.

$80 \%$ white, clear to frosted, medium-grained, fairly we11 sorted, sub-angular sand; $20 \%$ medium brown, soft clay matrix with some white mottling; abundant coarse grained sand.

$90 \%$ white, clear to frosted, medium-to coarse-grained, sub-rounded sand; $10 \%$ white to brown mottled, soft clay matrix.

No sample.

$80 \%$ white, clear to frosted, fine-grained, angular, fairly well sorted sand; $20 \%$ light tan, soft clay matrix; abundant coarse-to medium-grained sand; trace of heavy minerals.

No sample.

$75 \%$ sand as $38.5-44.0$ interval; $25 \%$ light tan, soft clay matrix. trace of heavy minerals.

$75 \%$ white to light gray, clear, fine-grained, angular, wel1 sorted sand; $25 \%$ brownish gray, soft clay matrix; scattered coarse-to medium grained-sand; trace of muscovite flakes.

$75 \%$ white, clear to frosted, fine-grained, angular, well sorted sand; $25 \%$ brownish gray, soft clay matrix; trace of heavy minerals and muscovite flakes.

$75 \%$ white, clear to frosted, fine-grained, angular, we11 sorted sand; $25 \%$ brownish gray, soft, poorly consolidated clay matrix; turns to light gray clay at 64.0 feet; trace of pyrite, muscovite flakes and heavy minerals.

No sample.

$70 \%$ white to light gray, clear to frosted, finegrained, angular, very well sorted sand; $30 \%$ medium grained, soft, poorly consolidated, silty clay matrix; some white mottling between 71.6 and 72.4 feet; trace of heavy minerals and muscovite flakes.

No sample. 


\section{Rocks of Oligocene Age}

$79.0-93.0$

Microcoquina; very light gray, indurated, microcrystalline, porous, highly weathered limestone matrix with abundant fossils; no diagnostic fauna. 


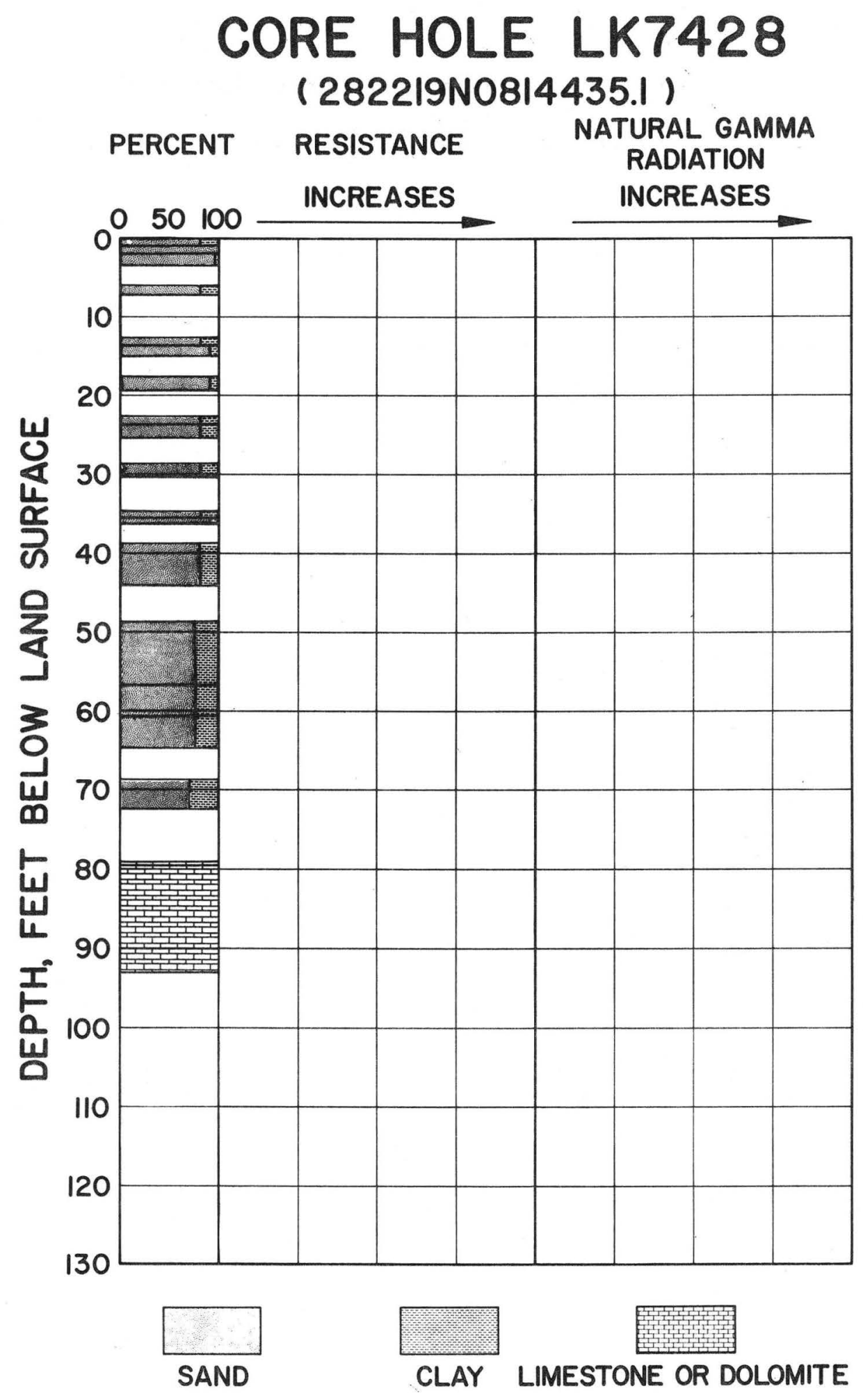


Lake County 282232N0814640.1

DEPTH INTERVAL (feet)

$2.5-6.0$

$6.0-14.7$

$14 \cdot 7-20.7$

$20.7-23.0$

$23.0-35.5$

$35.5-39.7$

$39.7-41.0$

$41.0-48.5$

$48.5-58.5$

$58.5-78.0$

$78.0-79.0$

\section{LITHOLOGY}

\section{Post Miocene Rocks}

95\% white, clear, fine-grained, fairly well sorted, sub-rounded sand; 5\% dark brown, dark gray, soft clay matrix; abundant medium-grained sand.

No sample.

$70 \%$ white, clear to frosted, fine-grained, fairly we11 sorted, sub-rounded sand; $30 \%$ creamy to light tan, indurated clay matrix; scattered medium-to coarse-grained sand.

$85 \%$ white to light gray, clear to frosted, coarseto very coarse-grained, poorly sorted, sub-rounded sand; $15 \%$ tan, soft clay matrix.

95\% white. clear to frosted, fine-grained, poorly sorted, sub-angular sand; $5 \%$ light tan, soft clay matrix; abundant coarse-to very coarse-grained sand.

No sample.

$80 \%$ white, clear to frosted, very fine-grained, well sorted, sub-angular sand; $20 \%$ light tan, soft clay matrix; trace of medium-grained sand and fine muscovite.

$65 \%$ sand as above; $35 \%$ clay as above; trace of muscovite flakes.

No sample.

Same as 39.7-41.0 interval.

$50 \%$ white, clear to frosted, very fine-grained, well sorted, sub-angular sand; $50 \%$ light tan to very light gray, soft clay matrix; trace of coarseto very coarse-grained sand and fine to very fine muscovite.

$60 \%$ sand as above; $40 \%$ medium to dark gray, banded, soft clay matrix; trace of muscovite. 
No sample.

\section{Rocks of 01igocene Age}

$83.0-102.5$

Creamy, microcrystalline, soft, porous, chalky, fossiliferous limestone; slightly clayey; no diagnostic fauna. 


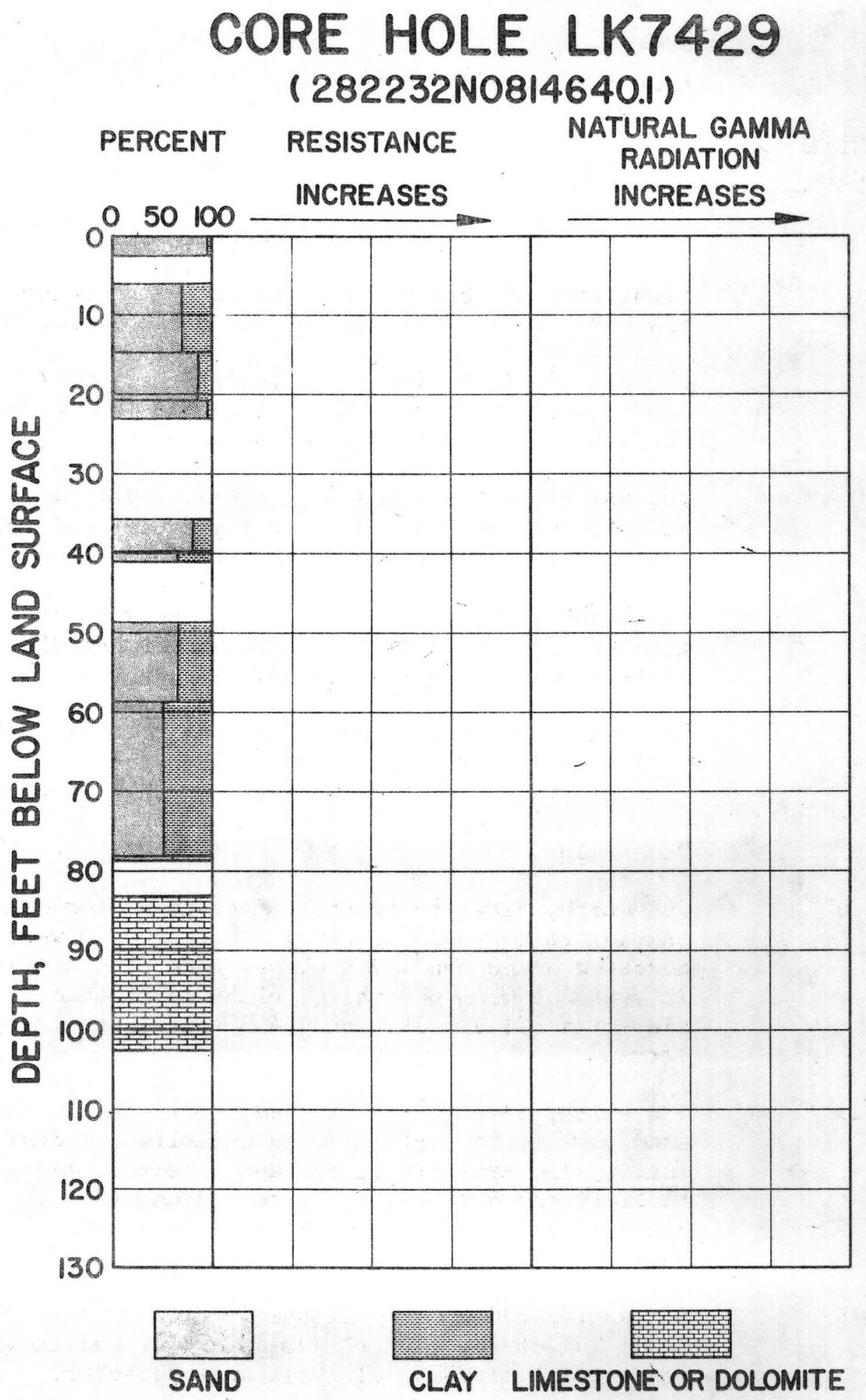


LK7430

Lake County 283247N0815154.1

DEPTH INTERVAL (feet)

$0.0-2.0$

$2.0-4.5$

$4 \cdot 5-11 \cdot 0$

$11.0-13.5$

$13.5-19.2$

$19.2-20.5$

$20.5-36.0$

$36.0-47.5$

$47.5-51.5$

$51.5-58.5$
LITHOLOGY

\section{Post Miocene Rocks}

Light gray and brown, clear to stained, mediumgrained, fairly well sorted, sub-angular sand.

$90 \%$ tan, stained, medium-grained, fairly we11 sorted, sub-rounded sand; $5 \%$ fine grained sand; $5 \%$ coarsegrained sand; trace of light brown clay.

$70 \%$ white, frosted, medium grained, fairly well sorted, sub-rounded sand; $25 \%$ light tan, soft clay matrix; $5 \%$ fine-to coarse-grained sand.

$75 \%$ 1ight gray, frosted, medium-to very coarsegrained, sub-rounded to well rounded sand; $25 \%$ light to medium tan, soft clay matrix.

$85 \%$ white, clear to frosted, medium-grained, fairly we11 sorted, sub-rounded sand; $10 \%$ white, soft clay matrix; $5 \%$ coarse to very coarse-grained sand.

No sample.

$50 \%$ white, clear to frosted, fine-to medium-grained, angular to sub-angular sand; $30 \%$ coarse-to very coarse-grained sand; $20 \%$ white, soft clay matrix; interbedded with $60 \%$ white, clear to frosted, fine-grained, angular sand, $40 \%$ white, soft clay matrix.

$55 \%$ white, clear, fine-grained, we11 sorted, angular sand; $30 \%$ white, soft, poorly consolidated clay matrix; 15\% medium-grained sand; trace of heavy minerals and muscovite; $1 / 4$ to 1 -inch wide bands of very coarse-grained sand throughout this interval.

$55 \%$ white, clear, fine-grained, angular, well sorted sand; $30 \%$ white, soft clay matrix; $15 \%$ medium-grained sand; trace of heavy minerals and muscovite.

$70 \%$ white, clear, fine-grained, angular, very well sorted sand; $30 \%$ very light gray, soft clay matrix; trace of heavy minerals and fine to coarse muscovite. 
$58.5-63.0$

$63.0-65.0$

$65.0-65.5$

$65.5-65.7$

$65.7-66.0$

$66.0-66.7$

$66.7-68.2$

$68.2-69.5$

$69 \cdot 5-73.0$

$73.0-73.5$

$73.5-78.0$

$78.0-80.0$
$50 \%$ very light gray, soft clay matrix; $40 \%$ sand as above; $10 \%$ medium-grained sand; trace of heavy minerals and muscovite.

$65 \%$ sand as $51.5-58.5$ interval; $35 \%$ off-white, indurated clay matrix; trace of heavy minerals and muscovite.

85\% light gray, clear to frosted, medium-grained, fairly well sorted, sub-angular sand; $10 \%$ very light green, soft clay; $5 \%$ fine and coarse-to very coarse-grained sand and trace of heavy minerals.

$60 \%$ very pale green, soft clay matrix; $40 \%$ light gray, clear to frosted, fine-to medium-grained, angular to sub-rounded sand.

$55 \%$ sand as above; $45 \%$ very light gray, soft clay matrix; trace of heavy minerals.

$70 \%$ white, clear to frosted, fine-to very fine-grained, angular, well sorted sand; $30 \%$ very pale green, soft clay matrix; trace of heavy minerals.

$80 \%$ off-white, soft, crumbly clay matrix; $15 \%$ light gray, clear to frosted, fine-to medium-grained, angular to sub-rounded sand; $5 \%$ coarse-grained sand; trace of heavy minerals and small fragments of white microcrystalline, soft, porous, silicified limestone.

$60 \%$ sand as above; $40 \%$ white, very pale green mottled, indurated, crumbly clay matrix; trace of limestone fragments as above.

$50 \%$ very light gray soft clay matrix; $45 \%$ white, clear, fine-grained, angular sand; $5 \%$ mediumgrained sand; trace of heavy minerals.

$50 \%$ light bluish green, soft clay; 45\% light gray, clear to frosted, medium-grained, fairly well sorted, sub-rounded sand; 5\% fine-grained sand; trace of heavy minerals.

No sample.

98\% white, and creamy mottled, soft, powdery, clay matrix; $2 \%$ white, clear, fine-grained, angular, well sorted sand. 
$80.0-80.7$

$70 \%$ pale green, light brown and white mottled, soft, crumbly clay matrix; $30 \%$ sand as above; trace of phosphate.

\section{Rocks of Miocene Age}

$80.7-82.5$

$50 \%$ sand as $78.0-80.0$ interval; $50 \%$ pale green, soft, poorly consolidated clay matrix; trace of brown phosphate nodules and blades; trace of white, microcrystalline, hard, porous, silicified limestone fragments.

$82.5-85.0$

$60 \%$ creamy, soft, poorly consolidated, crumb1y clay matrix; trace of phosphate as $80.7-82.5$ interval; $30 \%$ white, microcrystalline, hard porous, silicified limestone fragments; $10 \%$ sand as 78.0-80.0 interval.

$85.0-86.0$

$60 \%$ light green and creamy mottled, soft clay matrix; 35\% 1imestone fragments as 82.5-85.0 interval; $5 \%$ sand as $78.0-80.0$ interval.

$86.0-89.5$

$60 \%$ clay as 85.0-86.0 interval; trace of black, medium to very coarse phosphate nodules; $30 \%$

limestone fragments as 82.5-85.0 interva1; $10 \%$ white, clear, fine-to medium-grained, angular to sub-rounded sand.

$89.5-92.5$

$98 \%$ light gray and creamy mottled, soft, crumbly clay matrix; $2 \%$ sand as above.

$92 \cdot 5-97.0$

Creamy, buff, brown and green mottled, soft clay matrix; trace of fossil fragments and pisolitic silica.

$97.0-99.0$

$75 \%$ off-white, soft, crumbly clay matrix; $15 \%$ light gray, clear to frosted, medium-grained, fairly well sorted, sub-rounded sand; $10 \%$ light tan, microcrystalline, indurated, porous, silicified limestone fragments.

\section{Rocks of Eocene Age}

$99.0-107.0$

$80 \%$ off-white, microcrystalline, hard, porous limestone with $20 \%$ small fossils; highly weathered; contains Lepidocyclina ocalana floridana (Cushman), Sphaerogypsina globula (Reuss), Reusse1la sculptilis (Cushman).

107.0-112.0 No sample. 


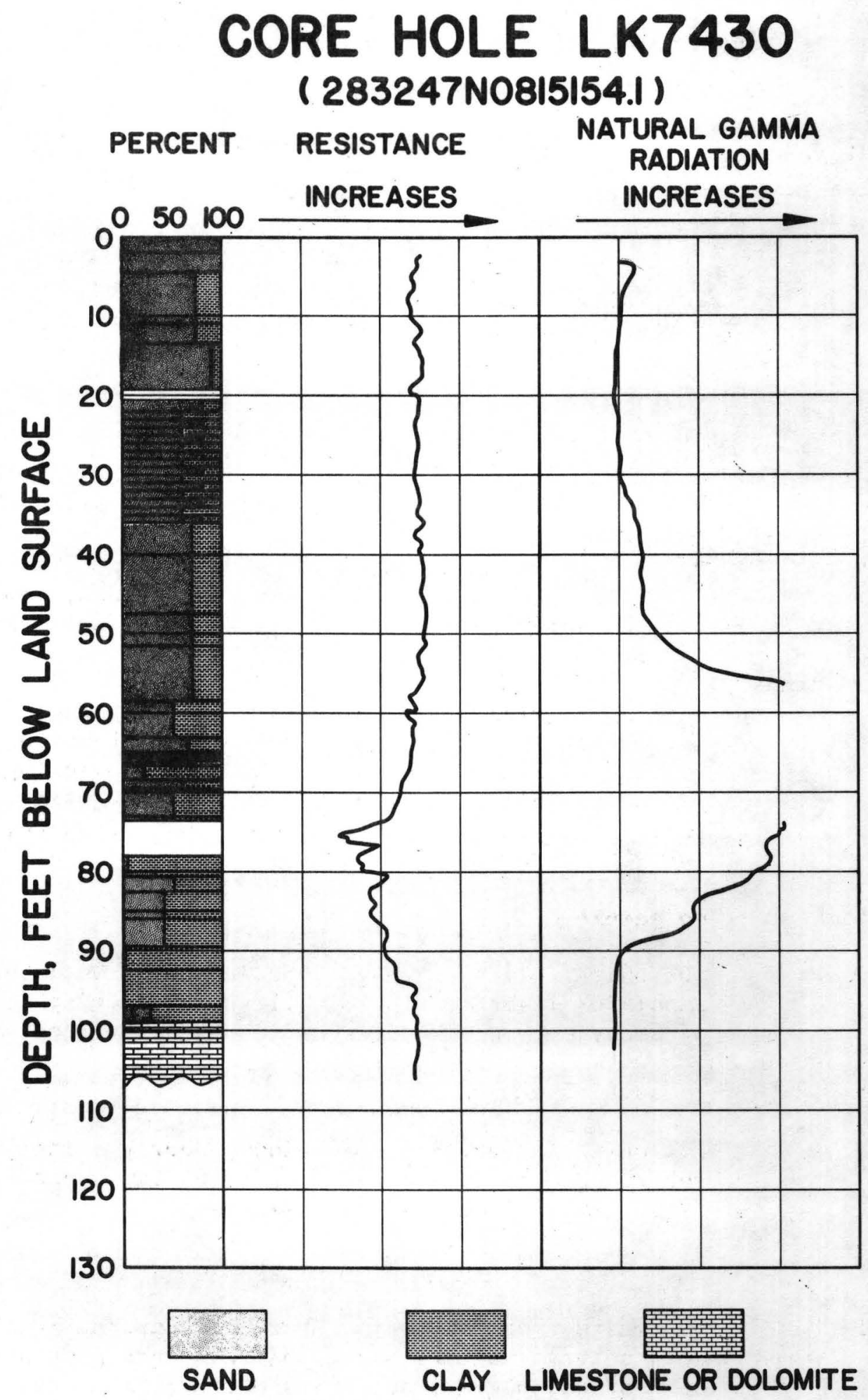


Lake County 282245N0814926.1

DEPTH INTERVAL (feet)

$3.0-6.0$

$6.0-7.0$

$7 \cdot 0-7.5$

$7 \cdot 5-18.5$

$18.5-19.5$

$19 \cdot 5-42.0$

$42 \cdot 0-47.5$

$47.5-50.5$

$50.5-52.5$
LITHOLOGY

\section{Post Miocene Rocks}

$60 \%$ white, clear to frosted, coarse-grained, poorly sorted, rounded sand; $40 \%$ light brown to light tan, indurated clay matrix.

No sample.

$50 \%$ white, clear to frosted, fine-grained, angular, poorly sorted sand; $50 \%$ off-white, soft, silty clay matrix.

$70 \%$ white, clear to frosted, coarse-grained, poorly sorted, sub-rounded sand; $30 \%$ light tan, soft clay matrix.

$50 \%$ white, clear to frosted, very fine-grained, fairly well sorted, angular sand; $50 \%$ off-white, soft, silty clay matrix interbedded with the following: $70 \%$ white, clear to frosted, very coarse-grained fairly we11 sorted, rounded sand; $30 \%$ off-white, soft, indurated clay matrix.

No sample.

$50 \%$ white, clear, fine-grained, angular, well sorted sand; $50 \%$ light tan, soft, silty clay matrix; trace of heavy minerals and medium-to coarse-grained sand.

No sample.

$70 \%$ white, clear, medium-grained, poorly sorted, sub-rounded to sub-angular sand; $30 \%$ tan, soft clay matrix; trace of heavy minerals.

\section{Rocks of Miocene Age}

$50 \%$ white to light gray, clear, fine-grained, fairly well sorted, angular sand; $45 \%$ very dark gray and dark brownish gray, soft clay matrix; 5\% black, fine phosphate nodules. 
$52.5-54.5$

$60 \%$ sand as above; $35 \%$ light greenish gray, soft clay matrix; $5 \%$ phosphate as above.

$54.5-56.5$

No sample.

$56.5-58.5$

Same as 52.5-54.5.

\section{Rocks of Eocene Age}

$58.5-62.5$

Very light gray, soft to indurated, microcrystalline, porous, poorly consolidated, highly weathered microcoquina; contains Lepidocyclina ocalana floridana (Cushman), Sphaerogypsina globula (Reuss), Cibicides mississippiensis ocalanus (Cushman), Reussella sculptilis (Cushman).

62.5-81.4 No sample. 


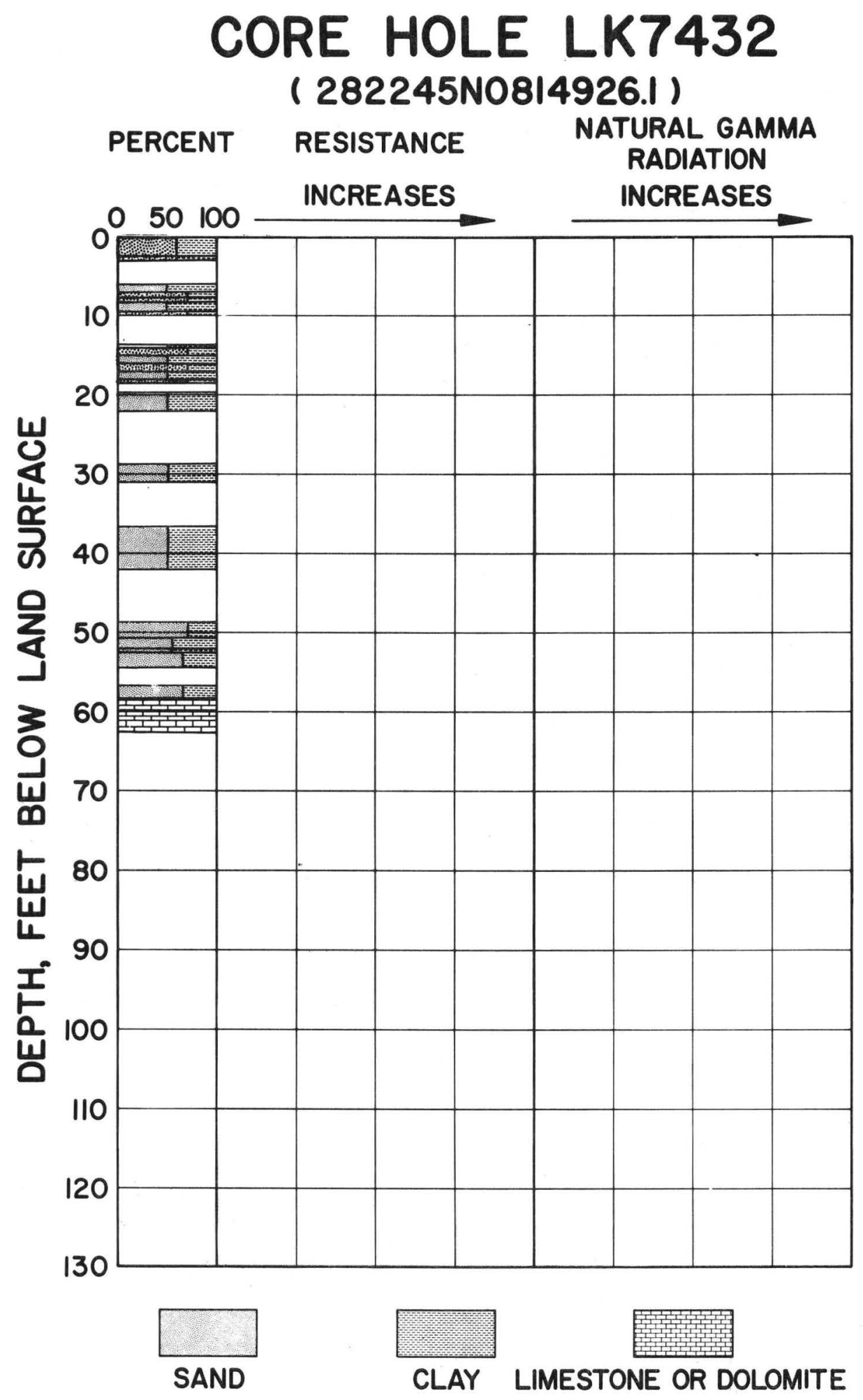


Sumter County 282840N0815835.1

DEPTH INTERVAL (feet)

$6.0-7.0$

$7.0-8.0$

$8 \cdot 0-11.0$

$11.0-12.0$

$12 \cdot 0-12 \cdot 5$

$12.5-15.0$

$15.0-15.5$

$15.5-16.0$

$16.0-17.0$

\section{LITHOLOGY}

\section{Post Miocene Rocks}

No sample.

$60 \%$ white to light brown, clear to stained, mediumgrained, fairly well sorted, sub-rounded sand; $40 \%$ medium to dark brown, indurated clay matrix with purple tint.

$60 \%$ sand as above; $40 \%$ medium to light brown mottled, soft clay matrix.

$65 \%$ sand as $5.0-6.0$ interval; $35 \%$ medium to light brown to light tan mottled, indurated clay matrix.

No sample.

$50 \%$ white, clear to frosted, fine,grained, angular, fairly we11 sorted sand; 50\% very light greenish gray, indurated clay matrix; trace of heavy minerals.

$65 \%$ sand as above; $35 \%$ clay as above with a slight pink cast.

No sample.

$75 \%$ white to light yellow, clear to stained, mediumgrained, fairly well sorted, sub-rounded sand; $25 \%$ light yellow and light tan mottled, soft clay matrix; 1.5-inch band of white, medium-grained sand at 16.2 feet; trace of heavy minerals.

75\% white, clear to frosted, medium-grained, fairly wel1 sorted, sub-rounded quartz sand; $25 \%$ light brown soft clay matrix; trace of heavy minerals.

$75 \%$ white, clear, fine-grained, fairly well sorted, sub-angular sand; $25 \%$ light greenish gray and tan mottled, soft clay matrix; 1/4-inch bands of greenish gray, soft, sticky clay; trace of heavy minerals. 
$17.0-22.0 \quad$ No sample.

22.0-29.0 75\% 1ight gray, indurated clay matrix; $25 \%$ white, clear, fine-grained, angular, well sorted sand.

$29.0-29.5$

$60 \%$ white, clear, fine-grained, fairly we11 sorted, sub-angular sand; $40 \%$ pale green and white mottled, soft clay matrix; trace of heavy minerals and fish teeth.

$29.5-30.0$

$70 \%$ 1ight brownish gray, white to creamy mottled, soft clay matrix; $30 \%$ sand as above.

$30.0-31.0$

$95 \%$ brownish gray and greenish gray, white and creamy mottled, soft clay matrix; $5 \%$ sand as 29.0-29.5 interval.

$31.0-31.5$

$90 \%$ olive green and bluish green, mottled soft clay matrix; $8 \%$ sand as $29.0-29.5$ interval; $2 \%$ very light tan phosphate nodules.

$31.5-32.0$

$75 \%$ olive green to bluish green, soft clay matrix mottled with creamy, soft fossiliferous clay; $20 \%$ sand as 29.0-29.5 interval; $5 \%$ phosphate as 31.0-31.5 interva1.

$32.0-32.7$

$75 \%$ light greenish gray and bluish green and olive green mottled, banded, soft clay matrix; $25 \%$ sand as 29.0-29-5 interval; trace of tan phosphate.

$32.7-33.0$

White, microcrystalline, hard, porous, silicified limestone with relict fossiliferous material.

$33.0-34.0$

Bluish green to greenish gray to buff, soft, sticky clay.

\section{Rocks of Eocene Age}

34.0-40.0 Creamy, microcrystalline, soft, porous limestone with abundant lignite and foraminifera; highly weathered; contains Lepidocyclina ocalana floridana (Cushman), Reusse1la sculptilis (Cushman), Cibicides mississippiensis ocalanus (Cushman). 
Lake County 282932N0815704.1

DEPTH INTERVAL (feet)

$0.0-1.0$

$1.0-1.5$

$1.5-2.5$

$2.5-5.0$

$5.0-5.5$

$5.5-11.0$

$11.0-11.5$

$11.5-12.5$

$12 \cdot 5-16.0$

$16.0-17.0$

$17.0-19.0$

$19.0-21.5$

$21.5-24.0$

\section{LITHOLOGY}

\section{Post Miocene Rocks}

$75 \%$ white to light gray, clear to frosted, mediumgrained, fairly well sorted, sub-rounded sand, $25 \%$ black, soft clay matrix.

$70 \%$ brown, stained, medium-grained, well sorted, sub-rounded sand; $30 \%$ dark brown, soft clay matrix.

White to light tan, clear to stained, medium-grained, fairly well sorted, sub-rounded sand; trace of light to medium tan clay.

No sample.

$75 \%$ white, frosted, medium-grained, fairly wel1 sorted, sub-rounded sand; $25 \%$ very light brown, soft clay matrix; trace of heavy minerals.

No sample.

$75 \%$ white, frosted, fine-to medium-grained, subrounded sand; $25 \%$ very light gray, soft, sticky clay matrix.

95\% white, frosted, medium-grained, fairly well sorted, sub-rounded sand; $5 \%$ very light gray, soft clay matrix; trace of heavy minerals.

$70 \%$ white, frosted, fine-to medium-grained, angular to sub-rounded sand; $30 \%$ very light brown, indurated to soft clay matrix; trace of heavy minerals.

No sample.

$75 \%$ white, clear to frosted, fine-grained, angular, well sorted sand; $25 \%$ tan, soft clay matrix.

$75 \%$ sand as above; $25 \%$ light tan and white mottled, soft clay matrix.

No sample. 
$24.0-25.0$

$25.0-25.5$

$25.5-26.0$

$6.0-27.0$

$27.0-28.0$

$28.0-32.0$

$32.0-41.7$
$90 \%$ creamy and light greenish gray to off-white mottled, soft clay matrix; $9 \%$ white, clear, finegrained, angular, well sorted sand; $1 \% 1$ ight tan, fine to medium phosphate nodules; trace of heavy minerals.

$60 \%$ sand as above; $35 \%$ very light greenish gray, soft clay matrix; $5 \%$ phosphate as above; trace of heavy minerals.

95\% dark greenish gray, soft clay matrix; 5\% white, clear, fine-grained, angular, fairly well sorted sand.

$90 \%$ 1ight bluish green, soft clay matrix, $10 \%$ sand as above.

\section{Rocks of Eocene Age}

Very light gray, microcrystalline, hard, porous, vuggy, silicified limestone with abundant fossil casts and molds; highly weathered; contains Sphaerogypsina globula (Reuss), Camperina sp. and Heterostegina sp.

No sample.

Light gray to creamy, microcrystalline, hard, porous, silicified, fossiliferous limestone. 


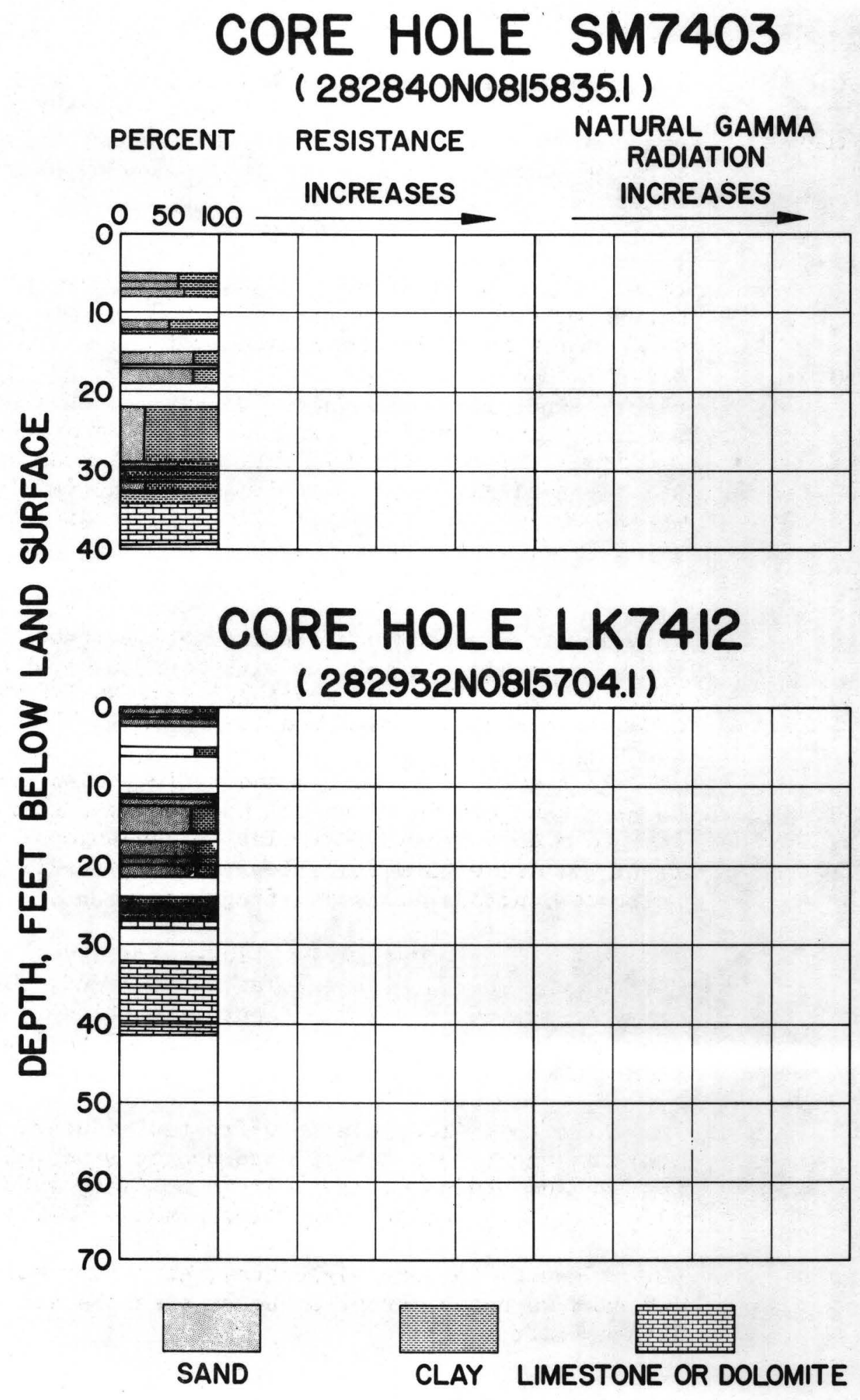


Sumter County 282430N0815958.1

DEPTH INTERVAL (feet)

$1.0-2.0$

$2.0-2.5$

$2.5-4.5$

$4 \cdot 5-5 \cdot 5$

$5.5-9.5$

$9 \cdot 5-10.0$

$10.0-12.0$

\section{LITHOLOGY}

\section{Post Miocene Rocks}

White, clear to frosted, fine-to medium-grained, fairly well sorted, sub-angular to sub-rounded quartz sand; trace of yellow to orange sand grains and dark gray clay.

$55 \%$ light gray, dul1 yellow and light brown mottled, indurated clay matrix; $45 \%$ white to yellow to orange, clear to frosted, fine-to medium-grained, fairly well sorted, angular to sub-rounded quartz sand; trace of heavy minerals and medium to fine limonite nodules.

$55 \%$ clay as above; $45 \%$ sand as above; trace of white, microcrystalline, indurated, porous limestone fragments.

$70 \%$ clay as $2.0-2.5$ interval; $30 \%$ sand as $1.0-2.0$ interval; trace of limestone fragments.

$50 \%$ light gray, dul1 yellow and medium brown mottled, soft, sticky clay matrix; $25 \%$ white, clear to frosted, fine-to medium-grained, angular to sub-angular quartz sand; $25 \%$ white to dull yellow, microcrystalline, indurated, porous limestone fragments.

$70 \%$ white, clear to frosted, fine-to medium-grained, fairly well sorted, sub-angular quartz sand; $30 \%$ dull yellow, white and light purple mottled, soft clay matrix; trace of heavy minerals and yellow sand grains.

$70 \%$ white to yellow, clear to frosted, fine-to mediumgrained, angular to sub-rounded quartz sand; $30 \%$ tan, medium brown and light brown mottled, soft clay matrix; trace of heavy minerals.

$90 \%$ off-white to very light gray, soft clay matrix; $10 \%$ sand as above; trace of heavy minerals and limestone fragments. 
Rocks of Eocene Age

$12.0-21.3$

$70 \%$ off-white, very fine-grained, soft, porous, chalky limestone with $30 \%$ large to small foraminifera and shell fragments; matrix of off white, soft, poorly consolidated, calcareous clay; contains Sphaerogypsina globula (Reuss), Lepidocyc1ina ocalana floridana

(Cushman), Cibicides mississippiensis ocalanus (Cushman), Reussella sculptilis (Cushman). 
Lake County 282435N0815423.1

DEPTH INTERVAL (feet)

$0.0-1.0$
$1.0-2.0$
$2.0-2.5$

$2.5-6.0$

$6.0-6.5$

$6.5-11.5$

$11.5-15.5$

$15.5-20.2$

$20.2-25.5$

$25.5-27.5$

$27.5-33.0$ $\underline{\text { LITHOLOGY }}$

\section{Post Miocene Rocks}

Light gray, clear to frosted, medium-grained, well sorted, sub-rounded to rounded quartz sand; trace of light gray clay.

$60 \%$ white to brown, clear to stained, medium-grained, fairly well sorted, sub-rounded quartz sand; $40 \%$ dark brown, soft, crumbly clay matrix.

$60 \%$ white, clear to frosted, medium-grained, fairly we11 sorted, sub-rounded quartz sand; $40 \%$ light tan, soft, crumbly clay matrix with minor dull yellow mottling; trace of heavy minerals.

No sample.

$65 \%$ light grayish brown, dull ye1low and dull orange mottled, indurated, clay matrix; $35 \%$ sand as $2.0-2.5$ interval; trace of heavy minerals.

$80 \%$ sand as $2.0-2.5$ interval; $20 \%$ light tan, soft, poorly consolidated clay matrix; trace of heavy minerals.

$70 \%$ sand as $2.0-2.5$ interva1; $30 \%$ light tan, indurated, clay matrix; trace of heavy minerals.

$65 \%$ sand as $2.0-2.5$ interva1; $35 \%$ tan, indurated, soft clay matrix.

$80 \%$ white, clear to frosted, fine-to medium-grained, angular to sub-rounded quartz sand; $20 \% \mathrm{tan}$, indurated clay matrix; trace of heavy minerals.

$55 \%$ white, clear to frosted, fine-grained, we11 sorted, angular quartz sand; $40 \%$ very light tan, silty, soft clay matrix; 5\% coarse-to medium-grained sand; trace of heavy minerals.

$55 \%$ fine-grained sand as above; $40 \%$ light to very light tan and indurated, silty clay matrix; $5 \%$ medium-grained sand. 


\section{Rocks of Miocene Age}

$33.0-33.5$

35.535 .5

$35.5-39.5$

$39.5-40.0$

$40.0-40.5$

$40.5-45.0$

$45.0-48.0$

$48.0-51.4$
$50 \%$ white, clear to frosted, medium-grained, we11 sorted, rounded quartz sand; $50 \%$ medium gray and light tan mottled, soft, silty clay matrix; trace of heavy minerals.

85\% 1ight tan, brownish gray and greenish gray mottled and banded, soft, waxy clay matrix; $10 \%$ white, clear to frosted, fine-grained, silty, we11 sorted quartz sand; $5 \%$ medium-to coarsegrained sand; trace of heavy minerals and tan, medium to fine phosphate nodules and blades.

$75 \%$ medium gray, soft sticky clay matrix; $10 \%$ white, clear, fine-to medium-grained, angular to sub-rounded quartz sand; $15 \%$ white, medium to coarse phosphate nodules and blades; trace of heavy minerals.

$80 \%$ medium gray, soft, fair1y we11 consolidated, sticky clay matrix with minor bluish gray mottling; $15 \%$ phosphate as above; $5 \%$ sand as above.

$70 \%$ light greenish gray and bluish gray mottled, soft, sticky clay matrix; $15 \%$ sand as $35.5-39.5$ interva1; $15 \%$ phosphate as $35.5-39.5$ interval.

\section{Rocks of Eocene Age}

$80 \%$ creamy, soft, porous, chalky, powdery, calcareous, highly weathered calcareous clay matrix; $20 \%$ creamy, microcrystalline, porous, chalky limestone fragments with large to small foraminifera; contains Sphaerogypsina globula (Reuss) and Lepidocyclina ocalana floridana (Cushman).

$80 \%$ calcareous clay as above; $15 \%$ white, clear to frosted, fairly well sorted, medium-grained quartz sand; $5 \%$ limestone fragments as above.

No sample. 


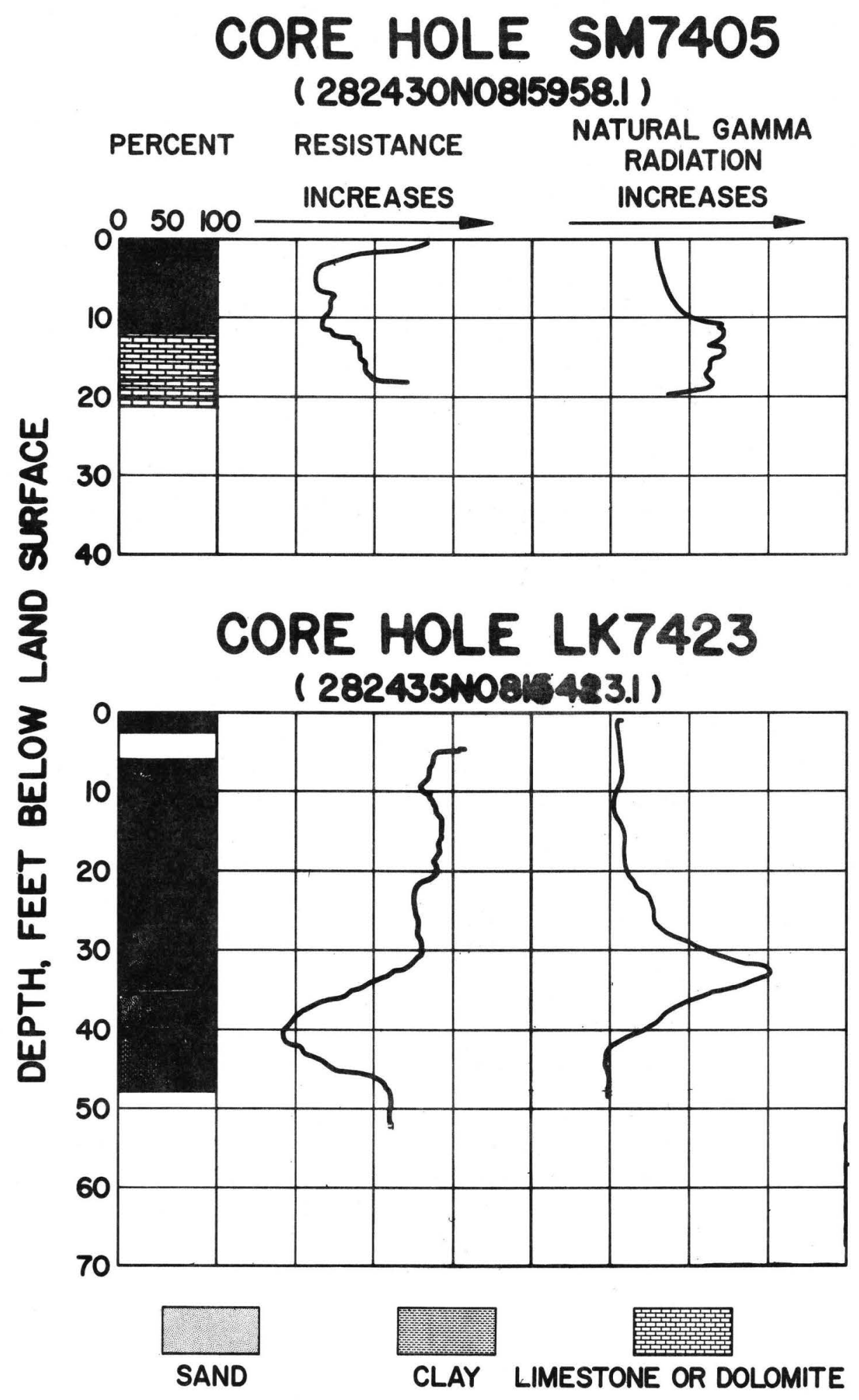


Sumter County 282631N0820303.1

DEPTH INTERVAL (feet)

$0.0-0.4$

$0.4-1.8$

$1.8-5.0$

$5.0-10.0$

$10.0-21.5$

$21.5-39.0$

$39.0-46.0$

$46.0-50.0$

$50.0-58.0$

\section{LITHOLOGY}

\section{Post Miocene Rocks}

Black, loose, organic sand.

White, loose sand; streaks of tan clay.

No sample.

$60 \%$ white, clear, fine-grained fairly well sorted, sub-angular, quartz sand; $40 \%$ tan and gray mottled, indurated clay; scattered small pockets and lenses of white and orange mottled, fine-grained quartz sand.

65\% white, clear, fine-grained, fairly we11 sorted, sub-angular quartz sand; $35 \%$ tan and gray mottled clay matrix; thin lenses of white, clear, finegrained, fairly well sorted quartz sand with just enough clay to bind throughout the interval; trace of black to brown, very fine phosphate.

$70 \%$ white, clear to frosted, fine-grained, fairly well sorted, sub-rounded quartz sand; $30 \%$ brownish gray, indurated clay; lenses of light brown, to white, clear, fine-grained, fairly well sorted, subangular quartz sand with just enough clay to bind; trace of black to brown, very fine phosphate nodules.

No sample.

$75 \%$ white to light gray, clear, fine-grained, fairly well sorted, sub-rounded quartz sand; $25 \%$ black and very dark brownish gray, indurated clay matrix; trace of very fine to fine phosphate nodules.

\section{Rocks of Eocene Age}

Cream, soft, poorly consolidated, very highly fossiliferous, calcareous clay. Fossils are large foraminifera and small shell fragments. From 54.1 to 55.1, 1-inch wide bands of brownish gray and greenish gray, soft, well consolidated, waxy clay with $30 \%$ sand in some parts; contains Lepidocyclina ocalana (Cushman) and Reussella sculptilis (Cushman). 
$58.0-62.0$

$50 \%$ white to light brownish gray, clear, fine-grained, fairly well sorted, sub-rounded quartz sand; $50 \%$ matrix of black, indurated clay very dark brownish gray streaks; trace of black, fine to very fine phosphate nodules.

$62.0-77.0$

Very light gray, indurated, calcareous, we11 consolidated, highly fossiliferous clay; poorly consolidated from 67.9 to 76.9 .

$77.0-81.0$

No sample.

$81.0-99.0$

Gray to greenish gray, soft to hard limestone; at 88.9 a 1 -foot band of dark brown and light brown and light gray and white mottled, soft, fairly well consolidated, calcareous clay with $40 \%$ fine-grained sand. 


\section{CORE HOLE SM740I}

\section{( 28263IN0820303.1)}

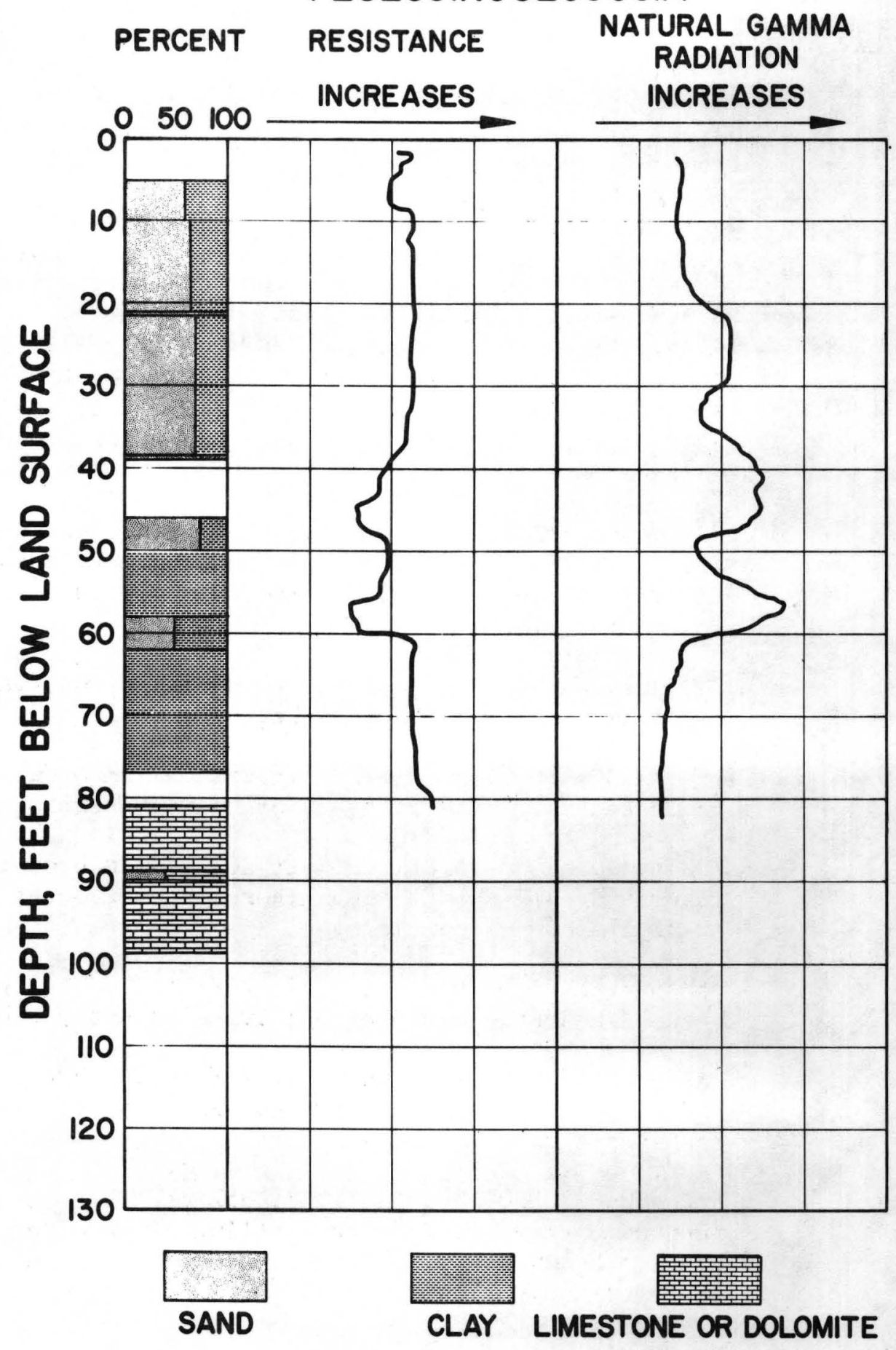


SM7402

Sumter County 282522N0820109.1

DEPTH INTERVAL (feet)

LITHOLOGY

\section{Post Miocene Rocks}

$0.0-0.6$

Black, loose, organic sand.

$0.6-2.0$

White, loose sand streaked with trace of brownish clay.

$2.0-3.0$

No sample.

$3.0-5.0$

$75 \%$ light gray, clear to frosted, medium-grained, well sorted, rounded quartz sand; $25 \%$ dark brownish gray, soft clay matrix.

$5.0-10.0$

$85 \%$ white to light tan, clear to frosted, mediumgrained, fairly well sorted, rounded quartz sand; $15 \%$ light brown, indurated clay matrix; trace of heavy minerals.

$10 \cdot 0-14.0$

$75 \%$ sand as above; $25 \%$ light to medium brown, indurated clay matrix; trace of heavy minerals.

$14.0-17.0$

$75 \%$ sand as $5.0-10.0$ interval; $25 \%$ medium brown, indurated clay matrix; trace of heavy minerals.

$17.0-19.0$

$70 \%$ sand as $5.0-10.0$ interval; $30 \%$ medium brown, indurated clay matrix with minor light tan mottling; trace of heavy minerals.

$19 \cdot 0-22.0$

$75 \%$ sand as $5.0-10.0$ interva1; $25 \%$ medium to 1 ight brown, indurated clay matrix; trace of heavy minerals.

$22.0-27.0 \quad 75 \%$ sand as $5.0-10.0$ interval; $25 \%$ medium brown, indurated clay matrix with minor light bluish gray mottling; trace of heavy minerals.

$27.0-30.5$

$65 \%$ sand as 5.0-10.0 interval; $35 \%$ dark brown, indurated clay matrix with mottling of pure very dark grayish brown, soft, waxy clay from 29.1 to 30.4 feet; trace of heavy minerals.

30.5-40.0 No sample. 
$40.0-47.5$

$47.5-50.0$

$50.0-55.0$

$55.0-57.0$

$57.0-60.0$

$60.0-61.0$

$61.0-63.0$

$63.0-64.0$

$64 \cdot 0-66.0$

$66.0-67.0$

$67.0-68.0$

$68.0-70.0$

$70.0-72.0$
$70 \%$ brown, clear to stained, medium-grained, subrounded, fairly well sorted quartz sand; $30 \%$ black and very dark brown mottled, indurated clay matrix; trace of heavy minerals.

No sample.

$80 \%$ sand as $40.0-47.5$ interval; $20 \%$ clay as $40.0-$ 47.5 interval; trace of heavy minerals.

$50 \%$ 1ignite; 40\% 1ight gray and light brown, clear to frosted, medium-grained, fairly well sorted, subrounded quartz sand; $10 \%$ light brown, indurated clay matrix.

$60 \%$ black, organic, indurated clay matrix with minor dark brown mottling; $25 \%$ 1ignite; $15 \%$ sand as above; trace of marcasite.

$60 \%$ black, indurated, organic clay matrix; $40 \%$ sand as 55.0-57.0 interva1; trace of lignite and marcasite.

$75 \%$ black, indurated, organic clay matrix with minor dark brown mottling; $25 \%$ sand as 55.0-57.0 interval; trace of lignite and marcasite.

$65 \%$ black, indurated, organic clay matrix with minor dark brown mottling; $35 \%$ white to light gray, clear to frosted, medium-grained, fairly well sorted, subrounded quartz sand; trace of marcasite.

$50 \%$ sand as $63.0-64.0$ interval; $50 \%$ medium brown and medium grayish brown mottled, soft, waxy, organic clay matrix; trace of heavy minerals.

$65 \%$ sand as $63.0-64.0$ interval; $35 \%$ black and very dark grayish brown mottled, organic, indurated clay matrix; trace of marcasite and heavy minerals.

$60 \%$ clay as $66.0-67.0$ interval; $40 \%$ sand as $63.0-$ 64.0 interval; trace of heavy minerals and marcasite.

$80 \%$ black and very dark grayish brown mottled, indurated, organic, sticky, waxy clay matrix; $20 \%$ sand as 63.0-64.0 interval; trace of heavy minerals and marcasite.

$90 \%$ black, soft, well consolidated, sticky, waxy, organic clay matrix; $10 \%$ sand as $63.0-64.0$ interval; trace of heavy minerals and marcasite. 
$72.0-76.0$

$76.0-78.0$

$78.0-80.0$

$80.0-87.0$

$87.0-89.0$

$89.0-91.0$

$91.0-92.0$

$92.0-96.9$
Black and dark brown mottled, soft, crumbly, waxy, organic clay; trace of sand, heavy minerals and marcasite.

Black, organic, crumbly, soft clay with light brown tint; trace of sand.

$65 \%$ black to very dark brown, soft, crumbly, organic clay matrix; $35 \%$ sand as $63.0-64.0$ interval.

$75 \%$ dark brown and black mottled, soft, crumbly, organic clay matrix; $25 \%$ sand as $63.0-64.0$ interval.

$80 \%$ black and dark brown mottled, soft, crumbly, organic clay matrix; $20 \%$ sand as $63.0-64.0$ interval.

$70 \%$ black and dark brown mottled, soft, organic, waxy clay matrix with scattered, small wood fragments; $30 \%$ sand as 63.0-64.0 interval; trace of marcasite.

$85 \%$ clay as 89.0-91.0 interval, with wood fragments; $15 \%$ sand as $63.0-64.0$ interval.

\section{Rocks of Miocene Age}

$60 \%$ black and dark brown mottled, organic, indurated to soft, crumbly, waxy clay matrix with scattered wood fragments; $40 \%$ sand as 63.0-64.0 interval. 


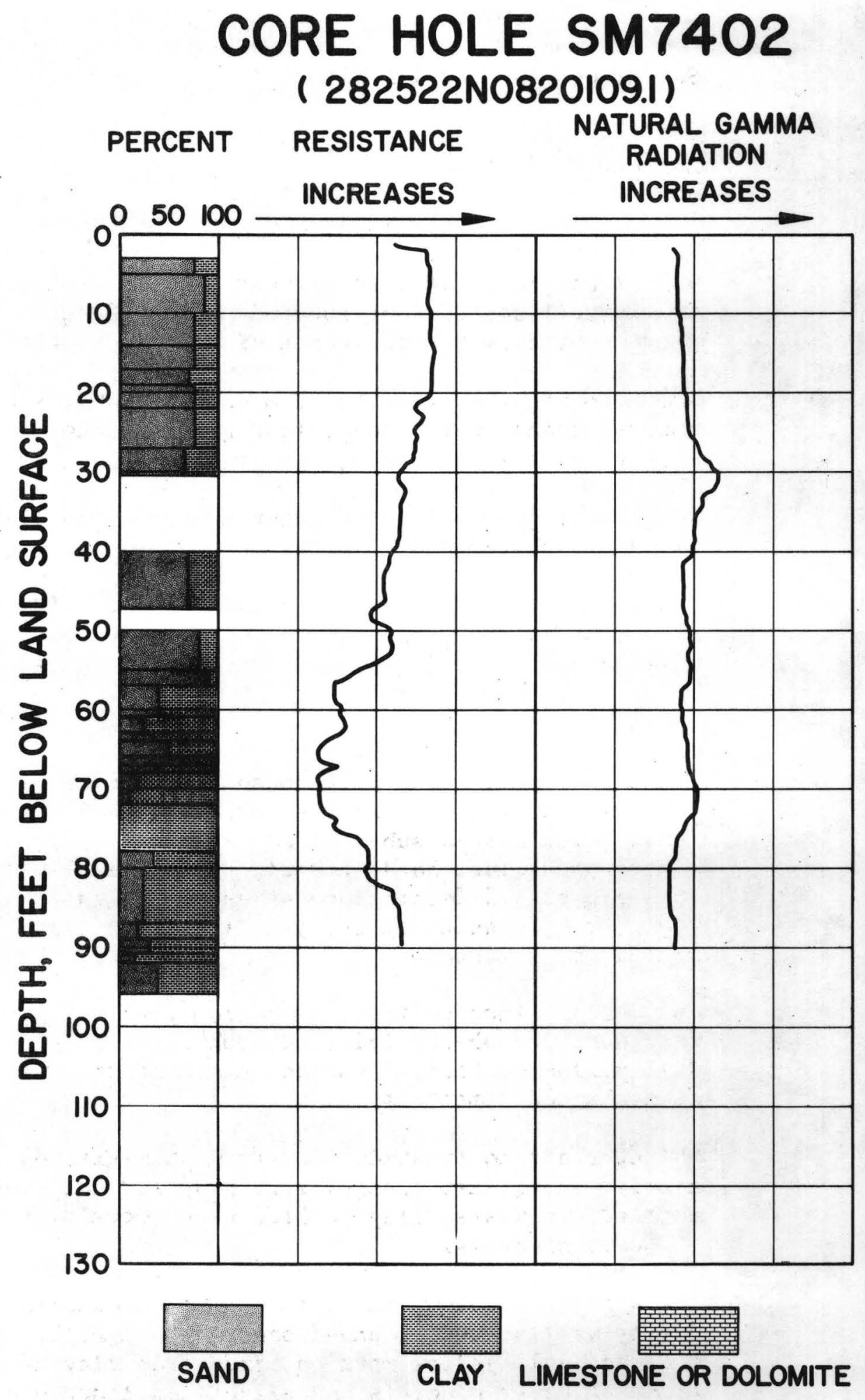


Sumter County 282616N0815921.1

DEPTH INTERVAL (feet)

$0.0-1.0$

$1.0-1.5$

$1.5-1.7$

$1.7-2.5$

$2.5-4.0$

$4 \cdot 0-5.5$

$5 \cdot 5-8.5$

$8.5-9.0$

$9 \cdot 0-9.5$
LITHOLOGY

\section{Post Miocene Rocks}

$90 \%$ light gray, clear to frosted, medium-grained, fairly well sorted, sub-rounded sand; $10 \%$ dark gray, soft clay matrix; trace of heavy minerals.

White to light gray, fine-to medium-grained, subrounded sand; just enough light gray clay to bind sand very loosely; trace of heavy minerals.

Very light gray, clear to frosted, medium-to finegrained, sub-rounded sand.

$70 \%$ white to light gray, fine-to medium-grained, subrounded sand; $30 \%$ very dark brownish gray, soft clay matrix.

No sample.

$70 \%$ light gray, soft, well consolidated clay matrix; $30 \%$ white to yellow, clear to stained, medium-grained, fairly well sorted sub-rounded sand; band of white, microcrystalline, hard, porous, silicified limestone from 5.0 to 5.5 feet; trace of heavy minerals and light gray to white microcrystalline, porous, hard, silicified limestone.

$70 \%$ white, clear to frosted, medium-grained, fairly we11 sorted, sub-rounded sand; 30\% light gray and dul1 yellow mottled, indurated clay; trace of heavy minerals and limestone.

White, clear to frosted, fine-to medium-grained, subangular sand; just enough light gray and dull yellow mottled, indurated clay to bind sand loosely; trace of heavy minerals.

$70 \%$ white to yellow, clear to stained, medium-grained, fairly well sorted, rounded sand; $30 \%$ light brownish gray and dull yellow mottled, indurated clay matrix; trace of heavy minerals and silicified limestone. 
$9.5-11.5$

$11.5-12.5$

$12 \cdot 5-13 \cdot 0$

$13.0-24.0$
$90 \%$ white, clear to frosted, medium-grained, fairly we11 sorted, sub-rounded sand; $10 \%$ off-white, indurated, clay matrix; trace of heavy minerals.

\section{Rocks of Miocene Age}

$50 \%$ white to light gray, clear to frosted, fine-to medium-grained, angular to sub-rounded sand; $45 \%$ bluish gray, brownish gray and dull yellow mottled, soft clay matrix; trace of heavy minerals and white to light gray, microcrystalline, hard, porous, silicified limestone.

$60 \%$ sand as above; $40 \%$ clay matrix as above; trace of pisolitic silica, fragments of white, microcrystalline, hard, porous, silicified limestone with relict fossils and heavy minerals.

\section{Rocks of Eocene age}

$60 \%$ off-white, soft, poorly consolidated, calcareous clay matrix; $40 \%$ off-white, microcrystalline, soft, porous, cherty limestone with fossils; fairly pure clay from 14.0 to 14.8 feet and from 20.0 to 21.0 feet; some mottling by light gray, soft, clay from 14.0 to 16.0 feet; contains Sphaerogypsina globula (Reuss), Reussella sculptilis (Cushman) and Jugosocythereis bicarinata (Swain). 
PS7401

Pasco County 282740N0820508.1

DEPTH INTERVAL (feet)

$1.1-3.0$

$3.0-8.0$

$8.0-17.0$

$17.0-22.0$

$22.0-24.0$

$24.0-29.0$

$29.0-31.0$

$31.0-31.5$
LITHOLOGY

\section{Post Miocene Rocks}

White to light brown, clear to stained, fine-to mediumgrained, fairly we11 sorted, sub-rounded quartz sand; trace of light brown and dark gray clay.

Light tan, clear to stained, fine-grained, well sorted, angular quartz sand; trace of heavy minerals.

90\% very light purple, stained, fine-grained, fairly we11 sorted, sub-angular quartz sand; $10 \%$ very 1 ight purple, indurated to soft clay matrix; trace of heavy minerals.

No sample.

$75 \%$ white, medium brown to dark brown, clear to stained, medium-to fine-grained, fairly well sorted, sub-angular to sub-rounded quartz sand; $25 \%$ light and dark brown mottled, soft clay matrix; trace of heavy minerals.

$70 \%$ white, clear, fine-grained, fairly well sorted, sub-angular sand; $30 \%$ thinly ( $1 / 16$ to $1 / 4-$ inch) crossbedded, tan and light brown indurated clay matrix; trace of heavy minerals.

$65 \%$ white, clear, fine-grained, well sorted angular quartz sand; $35 \%$ very light gray, indurated clay matrix; trace of heavy minerals.

$80 \%$ dul1 yellow, green and bluish green mottled, soft clay matrix; $20 \%$ sand, as above; clay has $20 \%$ white mottles in lower 0.3 foot; trace of heavy minerals.

$80 \%$ dull yellow and medium greenish gray mottled, soft clay matrix; $20 \%$ sand, as $24.0-29.0$ interval; a few sandy pockets; trace of heavy minerals. 


\section{Rocks of Miocene Age}

$31.5-32.0$

$32.0-33.0$

$33.0-37.0$

$37.0-39.0$

$39.0-43.0$

$43.0-49.0$
White, soft, crumbly clay with very minor mottling by light greenish gray, sticky clay.

White, soft, crumbly clay, with very minor mottling by a light greenish-gray, soft, sticky clay.

$80 \%$ white, greenish-gray, light gray, du11 yellow and medium brown mottled, soft, sticky clay matrix; $20 \%$ white, clear to frosted, fine-to medium-grained, fairly well sorted, angular to sub-rounded quartz sand; trace of heavy minerals and multicolored medium to very coarse phosphate nodules and blades.

$90 \%$ off-white, creamy, soft calcareous clay matrix with minor mottling by greenish gray and dull yellow mottled, soft clay; $6 \%$ very small to very large foraminifera; $4 \%$ fine-grained sand as $33.0-37.0$ interval; trace of light to dark brown, coarse to very coarse phosphate nodules.

\section{Rocks of Eocene Age}

$90 \%$ medium brown, light bluish to greenish gray mottled, soft, sticky clay matrix, mottled with cream soft, calcareous clay; $7 \%$ white, clear, fineto medium-grained, fairly well sorted, angular to sub-rounded quartz sand; $3 \%$ small to large foraminifera; the green to bluish gray clay contains the sand and the cream, calcareous clay contains the foraminifera.

$90 \%$ cream, soft, poorly consolidated, calcareous clay matrix; $10 \%$ creamy, fine-grained, indurated, porous, highly fossiliferous limestone; band of medium to dark brown, soft, well consolidated, sticky, waxy clay from 46.0 to 46.2 feet; contains Sphaerogypsina globula (Reuss), and Lepidocyclina ocalana floridana (Cushman). 


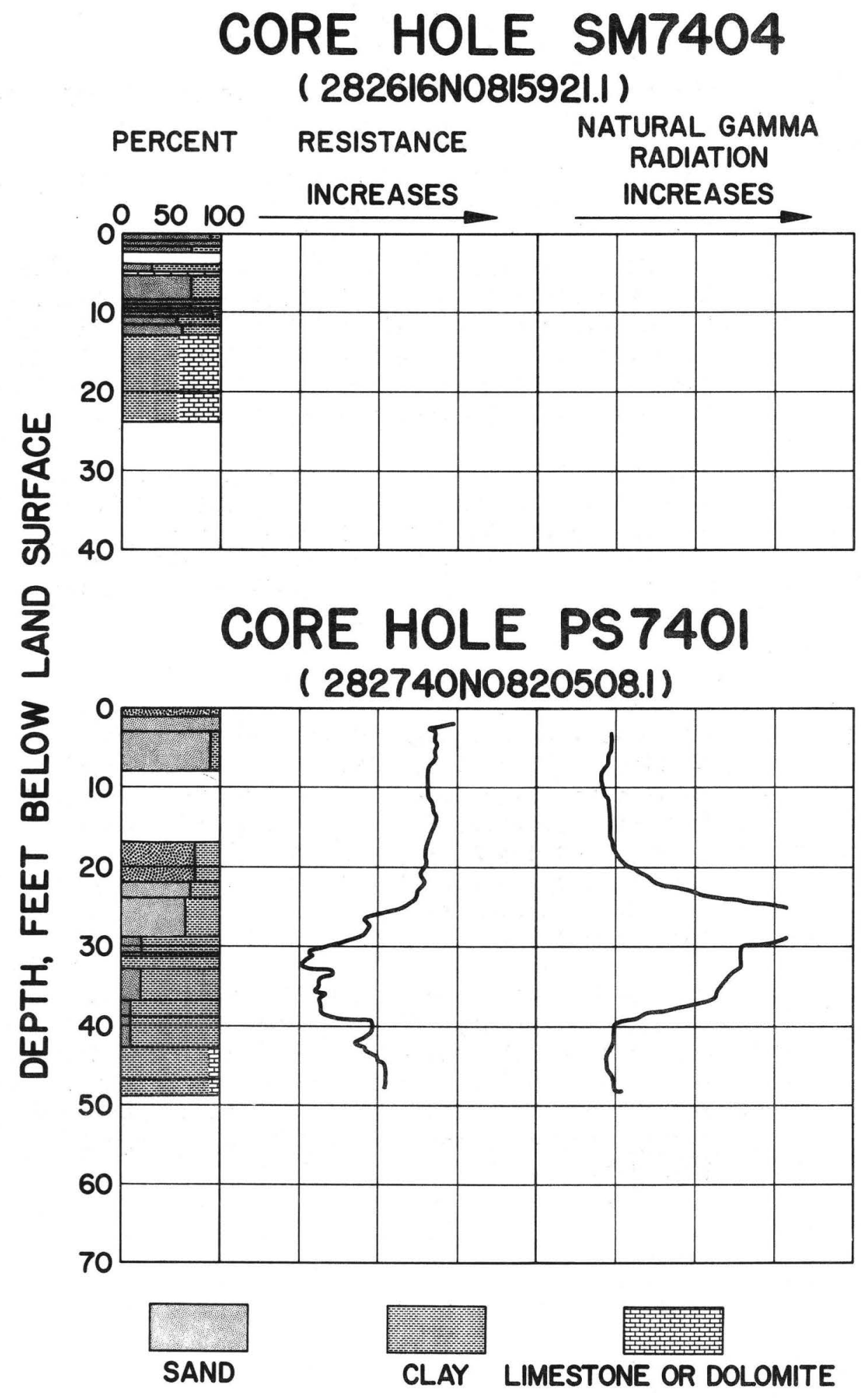


Sumter County 282509N0820108.1

DEPTH INTERVAL (feet)

$0.7-2.0$

$2 \cdot 0-3 \cdot 0$

$3.0-3.5$

$3.5-4.5$

$4.5-5.5$

$5.5-9.5$

$9.5-11.5$

$11.5-13.5$

$13 \cdot 5-14.5$

$14.5-16.5$

$16 \cdot 5-17.5$
LITHOLOGY

\section{Post Miocene Rocks}

$90 \%$ light gray, clear to frosted, medium-grained, we11 sorted, sub-rounded sand; $10 \%$ black, soft organic clay matrix; trace of heavy minerals.

Sand, as above, with a trace of brownish gray clay.

Sand, as 0.0-0.7 interva1, but is tan in color, and the quartz is stained.

$80 \%$ sand, clear to stained, medium-grained, fairly we11 sorted, sub-rounded sand; $20 \%$ light brown, soft clay matrix.

$55 \%$ white, clear to frosted, medium-grained, fairly well sorted, sub-rounded sand; $45 \%$ medium brown, soft clay matrix; trace of heavy minerals.

$55 \%$ white, clear to frosted, fine-to medium-grained, sub-angular to sub-rounded sand; $45 \%$ medium brown, indurated clay matrix with light gray tint; trace of heavy minerals.

$60 \%$ white, clear to frosted, fine-to medium-grained, sub-angular sand; $40 \%$ light to medium gray, indurated to soft clay matrix; dull yellow mottling and a light clay band from 7.5 to 8.0 feet.

No sample.

$80 \%$ sand, as $5.5-9.5$ interval; $20 \%$ light to medium brownish gray, indurated clay matrix, minor yellow mottling.

No sample.

$85 \%$ sand, as 5.5-9.5 interva1; $15 \%$ 1ight gray, indurated to soft clay matrix with minor yellow mottling.

No sample. 
$17 \cdot 5-18 \cdot 5$

$18 \cdot 5-19.5$

$19 \cdot 5-20.5$

$20.5-20.7$

$20.7-21.5$

$21.5-22.5$

$22.5-24.0$

$24.0-40.0$
$90 \%$ greenish gray and du11 yellow mottled, soft, waxy, sticky clay matrix, with some minor bluish gray mottling; $10 \%$ sand, as 5.5-9.5 interval.

90\% white, frosted, medium-grained, fair1y we11 sorted, sub-rounded sand; $5 \%$ light gray, soft, poorly consolidated clay matrix; trace of heavy minerals.

95\% off-white and greenish gray mottled, soft, waxy clay matrix; $5 \%$ white, frosted, fine-grained, fairly well sorted, sub-angular sand.

$90 \%$ greenish gray, soft, waxy clay matrix, mottled with off-white nodules and black organic material; $10 \%$ sand, as above; trace of heavy minerals.

$85 \%$ off-white to buff, soft waxy clay matrix, with very 1 ight greenish gray mottling; $15 \%$ white, clear, fine-grained, angular, well sorted sand; trace of heavy minerals.

$75 \%$ white, clear, fine-grained, angular, very well sorted sand; $25 \%$ light greenish gray and white mottled, soft clay matrix; trace of heavy minerals.

$50 \%$ sand, as above; $50 \%$ greenish gray and tan mottled, soft clay matrix.

No sample. 
PS7406

Pasco County 282109N0820733.1

DEPTH INTERVAL (feet)

$0.0-0.5$

$0.5-2.0$

$2.0-3.0$

$3.0-10.0$

$10.0-12.0$

$12.0-15.5$

$15.5-16.0$

$16.0-20.5$

$20.5-22.5$

$22.5-23.5$

$23.5-23.7$

$23.7-27.5$

$27.5-30.5$

\section{LITHOLOGY}

\section{Post Miocene Rocks}

Black, stained, fine-to medium-grained sand.

Organic material prominent.

White to gray sand.

Black to brown sand with angular fragments of iron oxide.

No sample.

$60 \%$ light greenish gray, indurated clay matrix with some yellow and light purple banding and mottling; $40 \%$ white, clear, fine-grained, angular, well sorted sand; trace of heavy minerals.

$60 \%$ very pale, greenish gray, medium brown and tan mottled and banded indurated clay matrix, with pockets of white indurated clay; $40 \%$ sand as above; trace of heavy minerals.

No sample.

$60 \%$ tan to dull yellow, indurated clay matrix; $40 \%$ white, clear, fine-grained, angular, well sorted sand.

$60 \%$ pale greenish gray, du11 yellow and tan mottled, indurated clay matrix; $40 \%$ sand, as above.

No sample.

$60 \%$ very light gray, indurated clay matrix with minor orange mottling; $40 \%$ sand, as $16.0-20.5$

interval.

$50 \%$ sand, as 16.0-20.5 interval; 50\% light gray, indurated clay matrix.

No sample. 
$30.5-34.0$

$34.0-35.0$

$35.0-38.5$

$38.5-40.0$

$40.0-45.5$

$45.5-47.5$

$47 \cdot 5-50.0$

$50.0-52.0$

$52.0-60.0$
$75 \%$ very pale greenish gray, soft, waxy clay matrix, becomes mottled and banded with light purple between 32.0 and 33.6 feet; $25 \%$ sand, as $16.0-25.5$ interval.

$80 \%$ white, clear to frosted, fine-to medium-grained, fairly well sorted, sub-angular to sub-rounded sand; $20 \%$ light brown indurated clay matrix; trace of heavy minerals.

No sample.

$65 \%$ white to yellow, clear to stained, fine-grained, sub-angular, fairly we11 sorted sand; $35 \%$ du11 ye11ow to light gray and very pale green mottled, soft clay matrix; pockets of white indurated clay in last 0.5 feet.

$80 \%$ white to light gray, clear to frosted, fine-grained, fairly well sorted, sub-angular sand; $20 \%$ very light gray to very pale greenish gray, soft clay matrix with minor mottling by pale green clay and dull yellow, soft, sticky clay; trace of heavy minerals.

\section{Rocks of Miocene Age}

$80 \%$ calcareous clay matrix; $15 \%$ creamy, very finegrained, indurated porous limestone with abundant fossils; $5 \%$ sand, as above.

Large nodules of white and yellow mottled microcrystalline, hard, porous limestone; trace of sand.

$60 \%$ white microcrystalline, indurated, porous limestone; $40 \%$ sand, as 40.0-45.5 interval.

\section{Rocks of Eocene Age(?)}

Lost circulation, could not be re-established. 


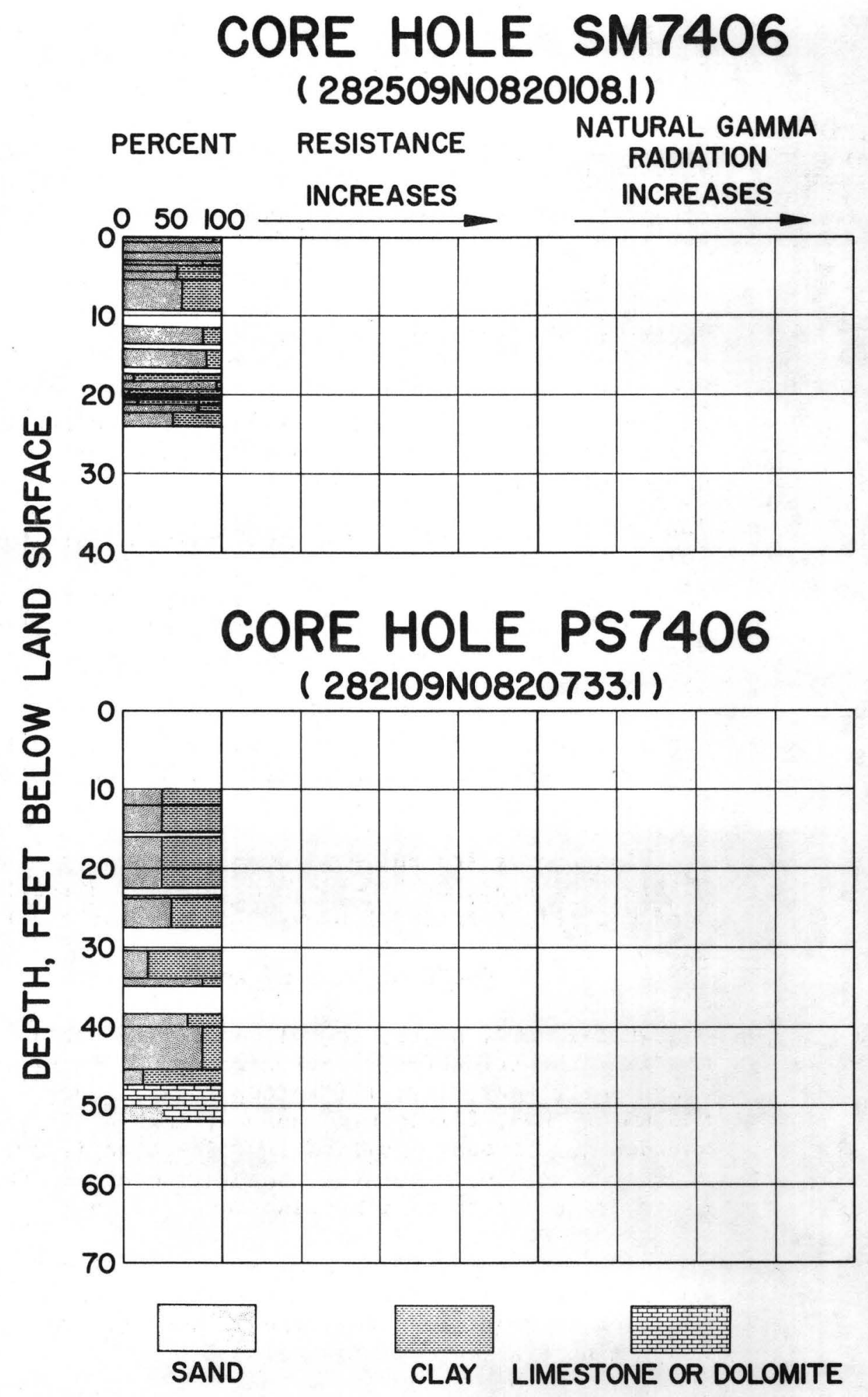


PS7408

Sumter County 282532N0820318.1

DEPTH INTERVAL (feet)

$0.0-1.0$

$1.0-5.0$

$5.0-6.5$

$6.5-7.0$

$7.0-8.0$

$8.0-10.0$

$10.0-14.0$

\section{LITHOLOGY}

\section{Post Miocene Rocks}

$90 \%$ light gray to brown, clear to stained, fine-to medium-grained, fairly well sorted quartz sand; $10 \%$ light brown, soft clay matrix.

$70 \%$ 1ight gray, clear to stained, fine-to mediumgrained, fairly well sorted, sub-rounded quartz sand; $30 \%$ dark gray, indurated clay matrix with minor medium brown mottling.

$55 \%$ white, clear, fine-to medium-grained, fairly well sorted, sub-angular to angular quartz sand; $45 \%$ tan to dark brown, dull yellow and white purple mottled and banded, indurated clay matrix, with $1 / 32$ to $1 / 8$-inch irregular bands of organic material throughout; trace of heavy minerals.

$60 \%$ dull yellow, light bluish gray and brown mottled and banded, indurated clay matrix; $40 \%$ sand, as above; trace of heavy minerals and organic material.

$75 \%$ bluish gray and dull yellow mottled, soft clay matrix; $10 \%$ sand, as 5.0-65 interval; $15 \%$ disseminated wood particles; trace of heavy minerals and siderite.

\section{Rocks of Miocene Age}

$85 \%$ white, soft, poorly consolidated, calcareous clay matrix with stringers of very light green to bluish gray, soft, waxy clay; $15 \%$ white, clear, fine-to medium-grained, fairly well sorted, angular to subrounded quartz sand; half of sand fraction is cream, microcrystalline, indurated, porous limestone fragments; trace of heavy minerals and siderite.

$70 \%$ sand, as above; $30 \%$ white, soft, calcareous clay, mottled with areas containing almost $100 \%$ sand; sand fraction is about 20\% limestone fragments; trace of heavy minerals. 
$14.0-16.0$

$16.0-17.0$

$17.0-18.0$

$18.0-26.0$
$60 \%$ white, clear, fine-to very fine-grained, fairly we11 sorted angular quartz sand; $40 \%$ light greenish gray to white, soft calcareous clay matrix; trace of heavy minerals and limestone fragments.

$70 \%$ very pale green, soft, crumbly, calcareous clay matrix with minor very pale, bluish green mottling; $30 \%$ creamy, microcrystalline, indurated, porous, fossiliferous limestone fragments; trace of white, clear, fine-to medium-grained sand.

$75 \%$ creamy to pale green, mottled, soft, crumbly clay matrix; 25\% limestone fragments as above; trace of sand, as above.

\section{Rocks of Eocene Age}

$80 \%$ off-white to creamy to soft, calcareous clay matrix; $20 \%$ white to creamy, fine-grained, indurated, porous, chalky limestone, with large to small fossil casts and molds. 
PS7402

Pasco County 242408N0820514.1

DEPTH INTERVAL (feet)

$0.0-3.5$

$3 \cdot 5-4.0$

$4.0-11.5$

$11.5-17.0$

$17.0-23.0$

$23.0-25.0$

$25.0-28.0$

$28.0-42.0$

\section{LITHOLOGY}

\section{Post Miocene Rocks}

No sample.

$60 \%$ white, clear to frosted, fine-grained, poor1y sorted, angular quartz sand; $40 \%$ brownish gray, indurated clay matrix; trace of heavy minerals.

$55 \%$ white, clear to frosted, medium-grained, poorly sorted, sub-rounded quartz sand; $45 \%$ light gray, indurated clay matrix; trace of heavy minerals.

$75 \%$ white, clear to frosted, fine-grained, fairly well sorted, sub-angular quartz sand; $25 \%$ light gray, indurated, soft clay matrix; trace of heavy minerals.

\section{Rocks of Miocene Age}

$85 \%$ pale greenish gray soft, waxy clay matrix with many nodules of white, soft clay; $15 \%$ white, clear to frosted, fine-grained, fairly well sorted, subangular quartz sand; trace of heavy minerals.

Pure, pale greenish gray, soft, waxy clay with nodules of white, soft clay.

\section{Rocks of Eocene Age}

White, soft, fairly well consolidated, slightly fossiliferous, calcareous clay; contains Bythocypris gibsonensis (Howe and Chambers).

No sample. 


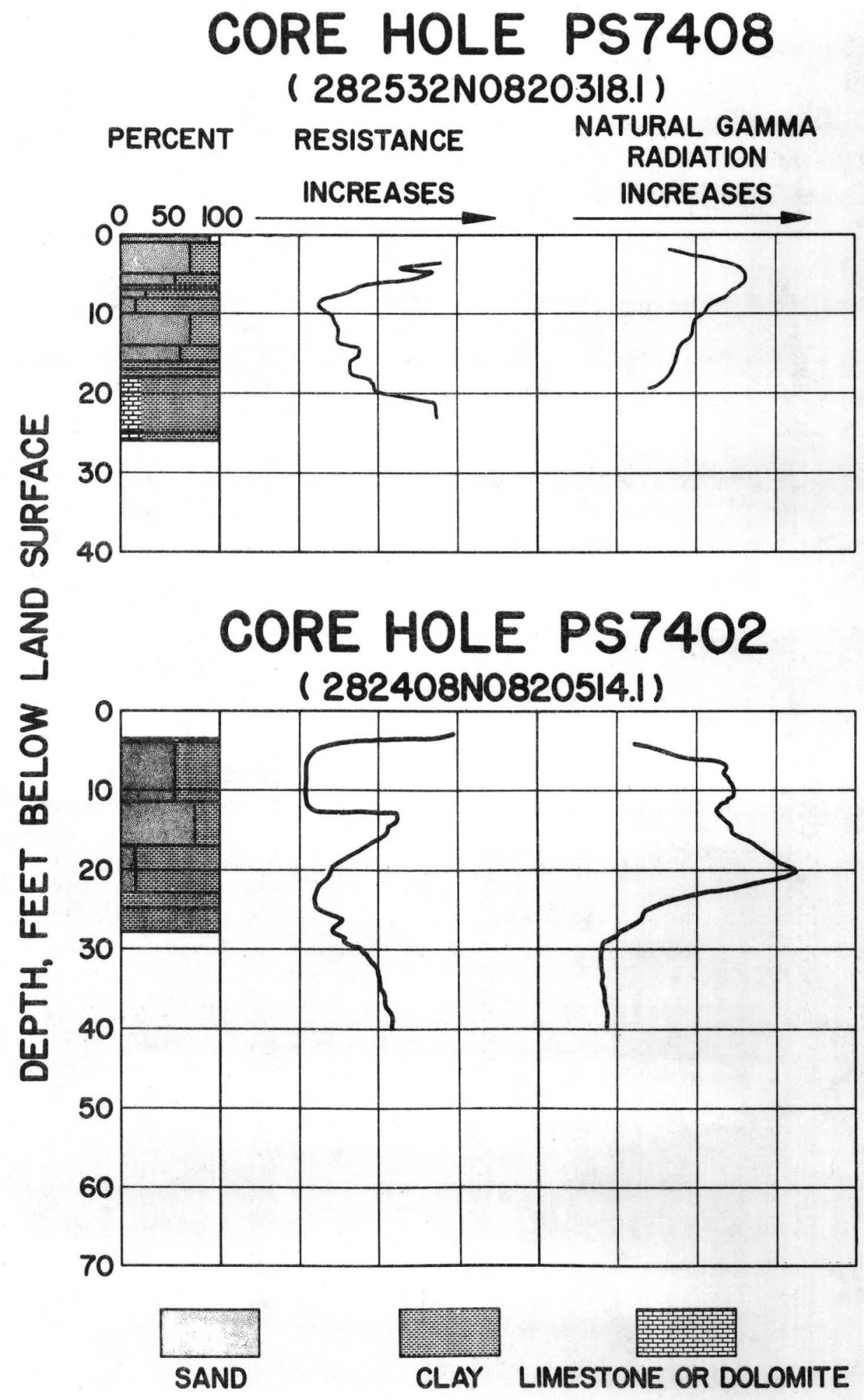


Pasco County 282505N0820655.1

DEPTH INTERVAL (feet)

\section{$0.0-0.5$}

$0.5-3.0$

$3.0-9.5$

$9.5-10.5$

$10.5-12.0$

$12.0-14.5$

$14 \cdot 5-19 \cdot 5$

$19.5-20.0$

$20.0-21.5$

$21.5-23.0$

$23.0-25.0$

$25.0-28.6$

\section{LITHOLOGY}

\section{Post Miocene Rocks}

Black, loose sand.

White, coase to fine-grained sand.

No sample.

95\% white, clear to frosted, fine-grained, fairly well sorted, angular quartz sand; 5\% light gray, indurated clay matrix; trace of heavy minerals.

$90 \%$ sand, as above; $10 \%$ light gray, indurated, orange banded clay matrix.

No sample.

$70 \%$ white, clear, fine-grained, we11 sorted, angular quartz sand; $30 \%$ light greenish gray and light gray banded and mottled, soft clay matrix; a very sandy band from 18.0 to 18.2 feet; trace of heavy minerals.

$60 \%$ white and light greenish gray mottled, soft clay; $40 \%$ sand, as above; trace of small shell fragments.

Sand, as 14.5-19.5 interva1, with just enough light gray, soft clay to bind sand loosely; has bands of pale green and tan banded soft clay from 20.6 to 20.8 feet and 21.4 to 21.5 feet.

95\% white, clear, fine-grained, fairly well sorted, angular quartz sand; $5 \%$ very light gray, soft clay matrix; trace of heavy minerals.

\section{Rocks of Oligocene Age}

$70 \%$ creamy, indurated, porous, microcrysta11ine, highly fossiliferous limestone, with some sparry calcite replacement; $30 \%$ matrix of creamy, soft, fairly we11 consolidated, calcareous clay; no diagnostic fauna.

No sample. 
PS7404

Pasco County 282220N0820933.1

DEPTH INTERVAL (feet)

$0.0-1.0$

$1.0-3.0$

$3.0-10.0$

$10.0-12.5$

$12.5-14.5$

$14 \cdot 5-17.5$

$17.5-20.5$

$20.5-23.0$

$23.0-26.0$

$26.0-30.0$

$30.0-32.0$
LITHOLOGY

Post Miocene Rocks

Black, loose, sand. Organic material prominent.

Yellowish, fine-to medium-grained sand.

No sample.

$60 \%$ white to yellow, clear, fine-grained, fairly we11 sorted, angular quartz sand; $40 \%$ very 1 ight gray, indurated clay matrix; with $1 / 8$ to $1 / 4-i n c h$ wide yellow clay bands; trace of heavy minerals.

$80 \%$ very light gray and light brown mottled soft clay matrix; $20 \%$ white, clear, fine-grained, fairly well sorted angular quartz sand.

\section{Rocks of Miocene Age}

$65 \%$ white to tan, clear to frosted, fine-grained, fairly well sorted, angular quartz sand; $35 \%$ interbedded light brown and very light gray, soft, indurated clay matrix; beds are $1 / 8$ to $1 / 2$-inch wide; trace of gypsum.

$60 \%$ sand, as above; $40 \%$ light golden brown, soft, clay matrix; 1ight tan and greenish gray mottling in lower 0.5 feet.

No sample.

$70 \%$ sand, as 14.5-17.5 interva1; $30 \%$ light golden brown indurated clay matrix.

No sample.

$70 \%$ white, clear, fine-grained, fairly well sorted, angular quartz sand; $30 \%$ white and light brown banded and mottled, soft clay matrix; trace of black organic material. 
$32.0-36.5$

$50 \%$ sand, as above; $50 \%$ clay, as above; trace of black organic material.

$36.5-39.0$

No sample.

$39 \cdot 0-40.5$

$50 \%$ white, clear, fine-grained, well sorted, angular quartz sand; $50 \%$ light gray, tan, dark brown and white mottled, banded, soft clay matrix; trace of black organic material.

$40.5-43.5$

$75 \%$ white, clear, fine-grained, well sorted, angular quartz sand; $25 \%$ yellow and dark brown mottled and banded indurated clay matrix.

\section{Rocks of Eocene Age}

$43.5-48.0$

White, soft clay with trace of fossiliferous material.

$48.0-51.0$

No sample.

$51.0-52.0$

Off-white, indurated, fairly well consolidated, fossiliferous clay with some off-white microcrystalline, indurated, porous, fossiliferous limestone nodules.

$52.0-53.5$

$50 \%$ off-white, microcrystalline, indurated, porous, fossiliferous limestone; $50 \%$ white, indurated, calcareous, well consolidated clay; many fossil molds and casts. 


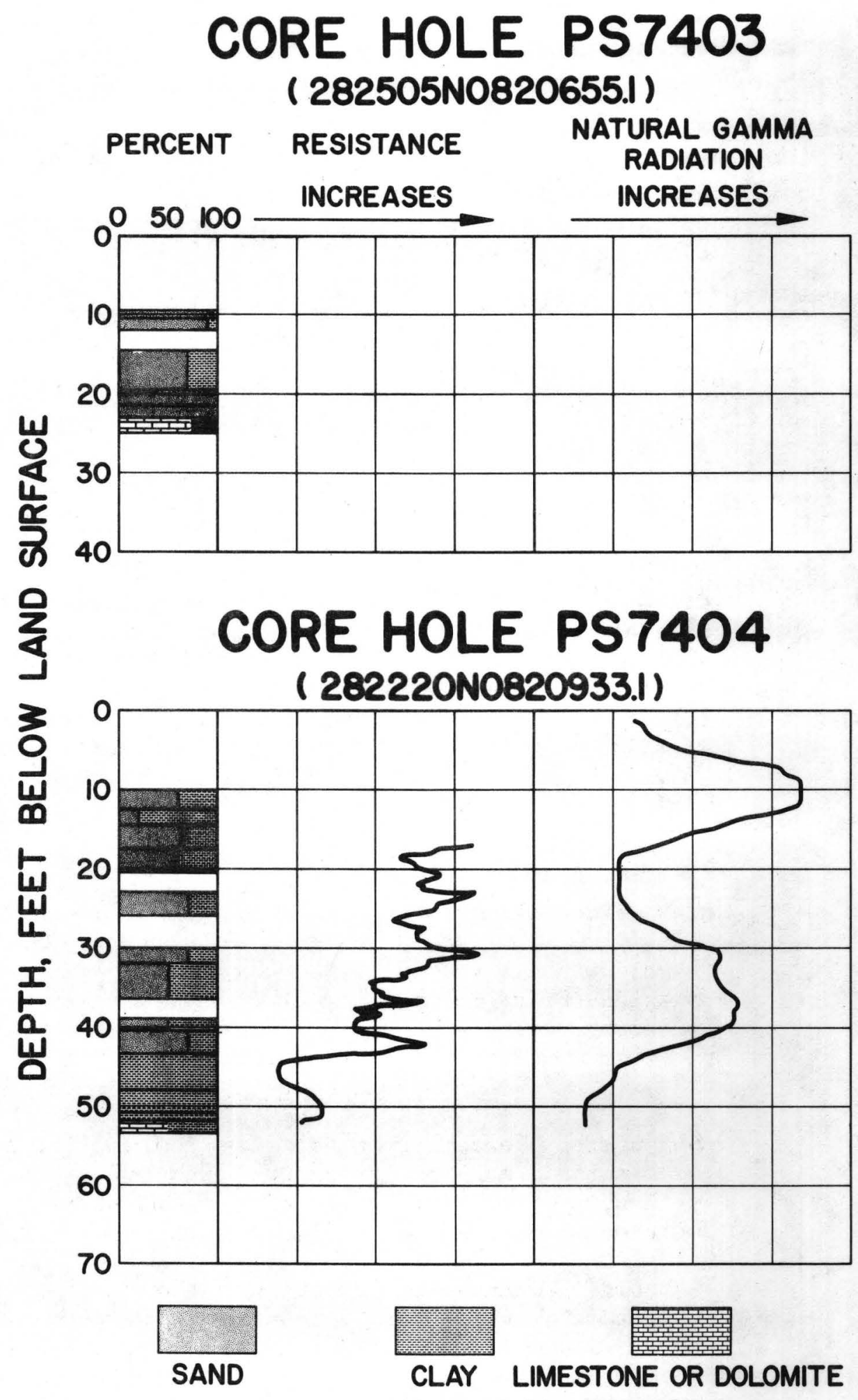


PK7402

Polk County 281809N0815614.1

DEPTH INTERVAL (feet)

$$
0.0-0.5
$$

$0.5-1.0$

$1.0-1.5$

$1.5-6.0$

$6.0-6.5$

$6.5-8.5$

$8 \cdot 5-10 \cdot 0$

$10.0-13.5$

\section{LITHOLOGY}

\section{Post Miocene Rocks}

White to light gray, clear, medium-grained, we11 sorted, sub-rounded quartz sand.

Light tan, stained, medium-grained, fairly well sorted, sub-rounded quartz sand; trace of light brown clay.

White to light brown, clear to frosted, fine-to medium-grained, fairly wel1 sorted, sub-angular to sub-rounded quartz sand; trace of light gray and light brown clay.

Sand, as above, with many brown, stained grains; trace of light brown and light gray mottled clay.

$70 \%$ white to dull yellow, clear to frosted, fine-to medium-grained, fairly well sorted, angular to subangular quartz sand; $30 \%$ light brown, light gray and light mottled, indurated clay matrix; trace of heavy minerals and limestone.

$70 \%$ white, clear to frosted, fine-to medium-grained, fairly well sorted, angular to sub-rounded quartz sand; $30 \%$ dull yellow, light gray, white and orange mottled, indurated clay matrix; trace of heavy minerals.

\section{Rocks of Miocene Age}

$60 \%$ white, clear to frosted, fine-grained, fairly we11 sorted, sub-angular quartz sand; $40 \%$ du 11 yellow, purple, light greenish gray and white mottled and banded, soft clay matrix.

$50 \%$ blue, greenish gray mottled, indurated clay matrix, mottled with white, soft to indurated pure clay; $40 \%$ white, clear to frosted, medium-grained, fairly we11 sorted, sub-rounded quartz sand; $10 \%$ white to tan medium to very coarse phosphate nodules. 
$13.5-15.5$

$50 \%$ sand, as above; $50 \%$ greenish gray, creamy and medium brown mottled, soft clay matrix, mottled with pure clay of greenish gray, creamy and medium brown color; trace of phosphate and heavy minerals.

\section{Rocks of Eocene Age}

$15.5-20.8$

$60 \%$ creamy, soft, very poorly consolidated, calcareous clay matrix; $40 \%$ creamy, microcrystalline, soft, porous limestone, with abundant fossils; contains Lepidocyclina ocalana floridana (Cushman), and Echinocythereis okeechobiensis (Swain). 
PK7401

Polk County 281839N0815331.1

\section{DEPTH INTERVAL (feet)}

$2.0-6.0$

$6.0-7.0$

$7 \cdot 0-9.0$

$9 \cdot 0-13.5$

$13.5-18.0$

$18.0-22.0$

$22.0-24.5$

$24.5-27.0$

$27.0-30.0$

$30.0-32.5$

\section{LITHOLOGY}

Post Miocene Rocks

Gray to light yellowish brown, clear to slightly stained, very fine-to medium-grained, sub-angular to sub-rounded sand; trace of light yellowish brown clay.

No sample.

$75 \%$ brown, stained, medium-grained, sub-rounded to rounded, water polished sand; $25 \%$ yellowish brown, gray mottled clay matrix.

Light tan with gray cast, medium-to fine-grained, frosted sand; trace of clay and very fine-grained black, heavy minerals.

Blue-gray clay with white mottling.

$70 \%$ light gray silty clay; $30 \%$ very fine-to finegrained sand, disassociated and concentrated in pockets.

Light gray silty clay.

\section{Rocks of Miocene Age}

$85 \%$ white, medium-to coarse-grained, rounded, waterpolished, well sorted quartz sand; $15 \%$ fine grained, angular to sub-angular quartz sand; trace of phosphate and pisolitic silica.

White to green silt; abundant pisolitic silica.

Bluish gray silt with pockets of medium-to coursegrained sand.

$55 \%$ bluish gray clay; $30 \%$ dark brown, medium-grained, water-polished sand; $15 \%$ off-white to light tan, medium to fine phosphate nodules; sand occurs in thin beds throughout the interval. 
Rocks of Eocene Age

$32.5-34.0$

55\% creamy, highly fossiliferous clay; 45\% large whole and broken foraminifera and bryozoans; contains Sphaerogypsina globula (Reuss), Lepidocyclina ocalana floridana (Cushman), Jugosocythereis bicarinata (Swain).

$34.0-61.0$

No sample. 


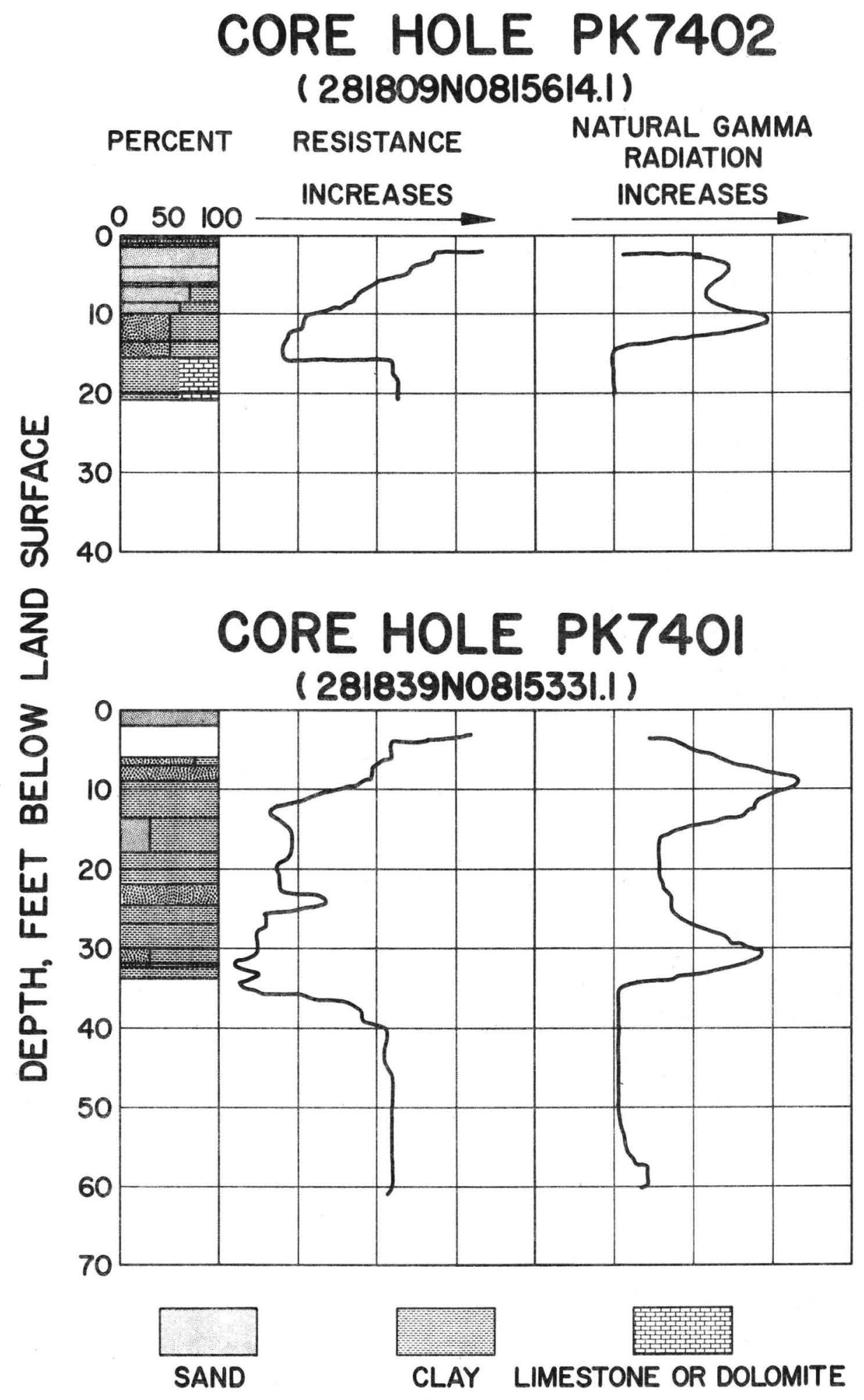


PK7403

Polk County 281530N0815730.1

DEPTH INTERVAL (feet)

$0.0-1.0$

$1.0-2.0$

$2.0-8.0$

$8.0-13.5$

$13.5-17.0$

$17.0-23.5$

$23.5-24.5$

$24.5-27.0$

$27.0-39.0$

$39.0-44.5$

$44.5-50.0$

\section{LITHOLOGY}

\section{Post Miocene Rocks}

Light gray, clear to frosted, medium-grained, fairly we11 sorted, sub-rounded quartz sand.

Light brown, clear to stained, medium-grained, fairly well sorted, sub-rounded quartz sand.

No sample.

95\% 1ight tan, frosted, medium-grained, well sorted, sub-rounded quartz sand; $5 \%$ tan, indurated, poorly consolidated, crumbly clay matrix; trace of heavy minerals.

$80 \%$ white to light tan sand, as above; $20 \%$ medium brown, indurated, crumbly clay matrix; trace of heavy minerals.

$55 \%$ light brown, clear to stained, medium-grained, fairly well sorted, sub-rounded quartz sand; $45 \%$ medium to dark brown mottled, indurated clay matrix; trace of heavy minerals.

$65 \%$ light, gray to white, clear to frosted, mediumgrained, we11 sorted, sub-rounded quartz sand; $35 \%$ medium brown, indurated clay matrix; trace of heavy minerals.

$75 \%$ sand, as above; $25 \%$ light brown, indurated clay matrix; trace of heavy minerals.

$75 \%$ sand, as $23.5-24.5$ interval; $25 \%$ tan, indurated, crumbly clay matrix.

$80 \%$ white to light tan, clear to stained, fine-grained, fairly well sorted, angular quartz sand; $20 \%$ light brown, indurated clay matrix; trace of heavy minerals.

$80 \%$ sand, as above; $20 \%$ light brown and very light tan mottled, indurated, crumbly clay matrix; trace of heavy minerals. 


\title{
Rocks of Miocene Age
}

\author{
$50.0-52.0$ \\ $55 \%$ sand, as $39.0-44.5$ interva1; $45 \%$ dark greenish \\ gray and brownish gray mottled, indurated, waxy clay \\ matrix with minor dark brown and light gray mottling; \\ trace of phosphate and heavy minerals. \\ $52.0-54.0$ \\ $50 \%$ light brown, light green and medium greenish gray \\ mottled, indurated clay matrix; $45 \%$ sand, as $44.5-$ \\ 50.0 interval; $5 \%$ black to gray to $\tan$, fine to very \\ coarse phosphate nodules. \\ $54.0-56.0$ \\ $50 \%$ sand, as 44.5-50.0 interval; $50 \%$ light brown and \\ medium gray banded and mottled, indurated clay matrix; \\ trace of heavy minerals and phosphate. \\ $56.0-60.0$ \\ $60.0-62.0$ \\ $50 \%$ very light tan, light brown and green mottled \\ banded soft clay matrix; $25 \%$ white and light gray, \\ clear to frosted, fine-to medium-grained, angular to \\ sub-rounded quartz sand; $25 \%$ black to tan, fine to \\ very coarse phosphate nodules; trace of heavy minerals. \\ $50 \%$ clay as above; $45 \%$ sand, as above; $5 \%$ small \\ phosphate pebbles; trace of heavy minerals and \\ phosphate nodules. \\ $62 \cdot 0-62.5$ \\ $60 \%$ very light tan and dark gray, soft, waxy clay; \\ $40 \%$ white, clear, fine-grained, fairly well sorted, \\ sub-angular quartz sand; abundant large fragments \\ of light gray to very dark gray chert. \\ $62.5-63.5$ \\ $90 \%$ medium brown, soft, sticky clay with minor dark \\ gray mottling; 10\% light brown, stained, medium - \\ grained, fairly well sorted, sub-rounded quartz sand; \\ trace of black, medium-grained phosphate nodules. \\ $63.5-65.0$ \\ $60 \%$ 1ight gray, stained, medium-grained, fairly well \\ sorted, sub-rounded quartz sand; $40 \%$ dark gray and \\ dark brown mottled, soft clay matrix; trace of heavy \\ minerals and black to tan, medium to coarse phosphate \\ nodules. \\ $65.0-66.0 \quad 65 \%$ sand, as above; $35 \%$ medium gray and medium brown- \\ ish gray mottled, soft clay matrix; trace of heavy \\ minerals and phosphate. \\ $66.0-68.0$ \\ 95\% dark, bluish gray, dark brownish gray, mottled \\ and banded, soft, sticky clay matrix, with pockets \\ of pure tan clay; $5 \%$ white, clear to frosted, fine- \\ grained, well sorted, angular quartz sand.
}


$68.0-69.0$

$69.0-71.0$

$71.0-91.0$

$91.0-95.0$

$95.0-97.0$

$97.0-98.0$

$98.0-103.5$

$103.5-106.0$

$106.0-120.0$

$120.0-128.0$
97\% dark b1uish gray, dark brown and dark greenish gray mottled, soft, sticky clay matrix with a few fragments of white silicified limestone; $3 \%$ sand, as above.

$50 \%$ sand, as 66.0-68.0 interva1; 50\% 1ight gray, indurated, crumbly clay matrix; half of sand fraction is pisolitic silica and fragments of silicified limestone and chert.

No sample.

$50 \%$ light brown, frosted, medium-grained, fairly we11 sorted, sub-angular quartz sand; $50 \%$ dark gray and medium brown mottled, soft, sticky clay matrix; trace of phosphate and limestone fragments.

$50 \%$ sand, as above; $50 \%$ black, soft, crumb1y clay matrix; sand fraction is $20 \%$ white, silicified limestone fragments and pisolitic silica; trace of marcasite.

$55 \%$ sand, as $91.0-95.0$ interva1; 45\% black and dark gray, soft, crumbly clay matrix; trace of marcasite and limestone fragments.

$70 \%$ sand as $91.0-95.0$ interval; $30 \%$ dark gray and dark brown mottled, soft, crumbly clay matrix, with scattered pockets of black, soft clay; trace of limestone fragments.

$50 \%$ medium brown, soft, crumbly clay matrix; $30 \%$ white, clear to frosted, fine-to medium-grained, angular to sub-rounded quartz sand; $20 \%$ white silicified limestone, chert and pisolitic silica.

No sample.

$45 \%$ black and medium grayish, mottled, crumbly clay matrix; $30 \%$ sand as 103.5-106.0 interval; $25 \%$ limestone, chert, and pisolitic silica, as above; trace of large foraminifera; interval contained a 4-inch diameter fragment of dark gray chert that had replaced fossilized limestone. 


\section{$\underline{\text { Rocks of Eocene Age }}$}

$128.0-157.0$

$70 \%$ creamy, soft, microcrystalline, porous, highly weathered 1imestone; $30 \%$ large to sma11 foraminifera; limestone becomes harder toward bottom of interval; contains Camerina sp. and Lepidocyclina ocalana floridana (Cushman). 
PK7404

Polk County 281531N0815457.1

DEPTH INTERVAL (feet)

$0.0-2.0$

$2.0-4.0$

$4.0-7.5$

$7.5-9.5$

$9 \cdot 5-12.0$

$12.0-16.0$

$16.0-25.0$

$25.0-30.0$

\section{LITHOLOGY}

\section{Post Miocene Rocks}

White to very light brownish gray, clear to frosted, medium-to fine-grained, fairly well sorted, sub-rounded quartz sand.

$60 \%$ black, soft, highly organic clay matrix; $40 \%$ white to light tan, clear to frosted, fine-grained, fairly well sorted, sub-angular quartz sand; trace of dull yellow grained sand and heavy minerals.

95\% white, clear, we11 sorted, fine-grained, angular quartz sand; $5 \%$ black, dull yellow, white, light to medium brownish gray, mottled, soft, sticky clay; trace of siderite and heavy minerals.

$50 \%$ white, clear, fine to medium-grained, fairly well sorted, sub-rounded quartz sand; $50 \%$ very 1 ight gray, dull yellow and light brown mottled, indurated clay matrix; bright orange and dull brick red mottling in upper 1 foot of this interval; trace of orange quartz sand grains and heavy minerals.

$50 \%$ white, clear, fine-to very fine-grained, angular, we11 sorted, quartz sand; $50 \%$ very light gray, dull yellow and purple mottled, soft, silty clay matrix.

$60 \%$ white, clear, fine-to very fine-grained, very wel1 sorted, angular quartz sand; $40 \%$ light gray, soft clay matrix; trace of heavy minerals.

\section{Rocks of Miocene Age}

$60 \%$ light greenish gray and off-white mottled, soft, indurated clay matrix; $40 \%$ sand, as above.

$60 \%$ light greenish gray and creamy mottled, soft, sticky clay matrix; $40 \%$ white, clear, very finegrained, fairly well sorted, angular quartz sand; trace of heavy minerals. 
$30.0-32.0$

$32.0-37.0$

$37.0-38.0$

$38.0-41.0$

$41.0-48.0$

$48.0-60.0$
$60 \%$ light greenish gray, soft, sticky clay matrix;

$40 \%$ white, clear, fine-to medium-grained, fairly well sorted, sub-angular quartz sand; trace of heavy minerals; light greenish gray and dull mottled bands of clay in lower 1 foot of this interval.

75\% 1ight, greenish gray, medium brownish gray, creamy and olive green mottled, soft, sticky clay matrix; 25\% white, clear to frosted, fine-to mediumgrained, fairly well sorted, angular to sub-rounded quartz sand; trace of heavy minerals and multicolored fine to very coarse phosphate nodules.

$80 \%$ olive green and bluish gray mottled, soft, sticky clay matrix; $20 \%$ sand, as above; trace of heavy minerals, phosphate and limestone fragments.

$50 \%$ olive green, light gray and bluish gray mottled, soft, sticky clay matrix; $35 \%$ sand, as $32.0-37.0$ interval; $15 \%$ creamy, microcrystalline, indurated, porous limestone fragments; trace of heavy minerals and phosphate.

\section{Rocks of Eocene Age}

$75 \%$ creamy, soft, poorly consolidated, calcareous clay matrix (weathered 1imestone); $25 \%$ cream, fine, grained, indurated, porous limestone with fossil material; contains Lepidocyclina ocalana floridana (Cushman), Cibicides mississippiensis ocalanus (Cushman), Reussella sculptilis (Cushman), and Echinocythereis okeechobiensis (Swain).

No sample. 


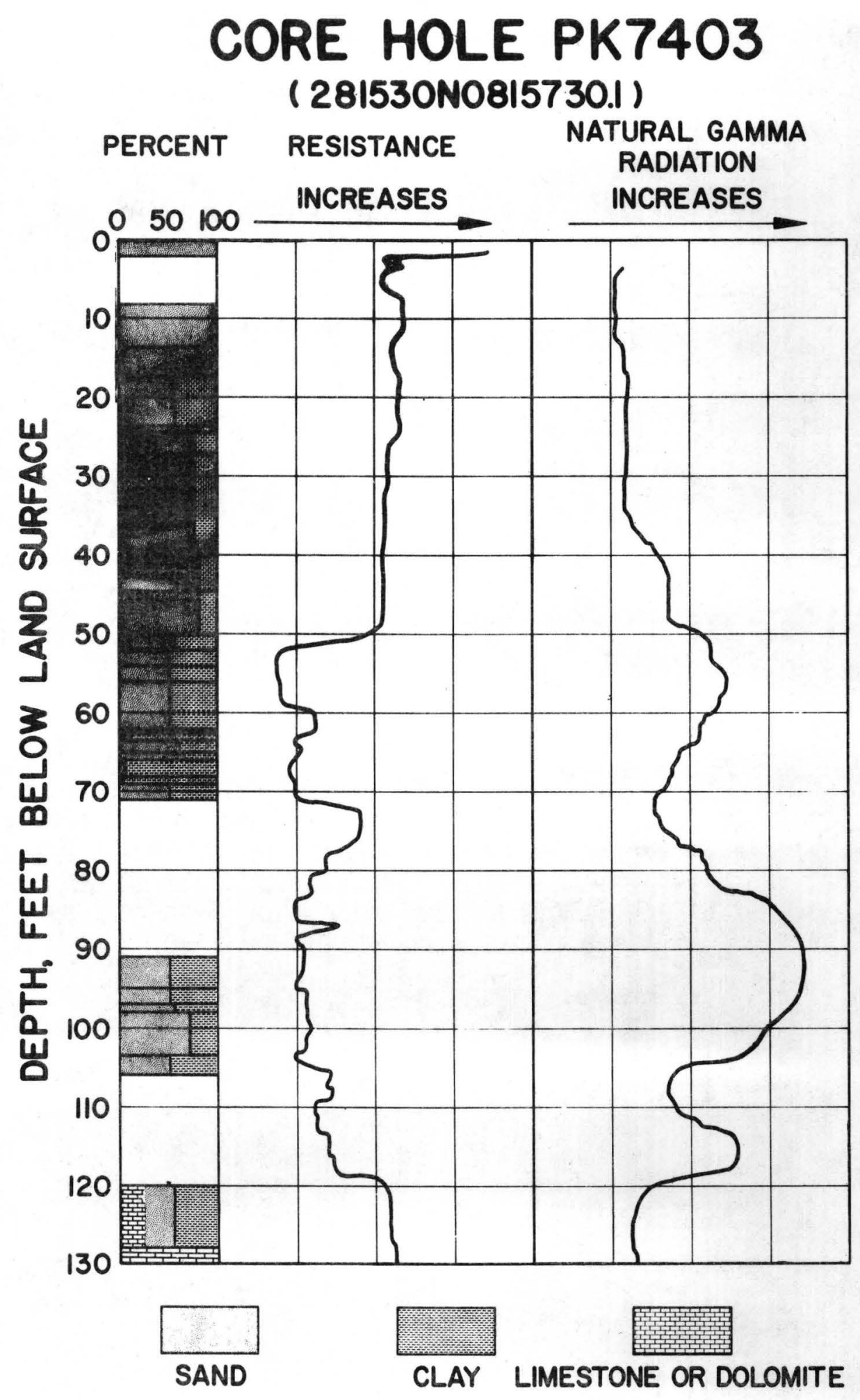




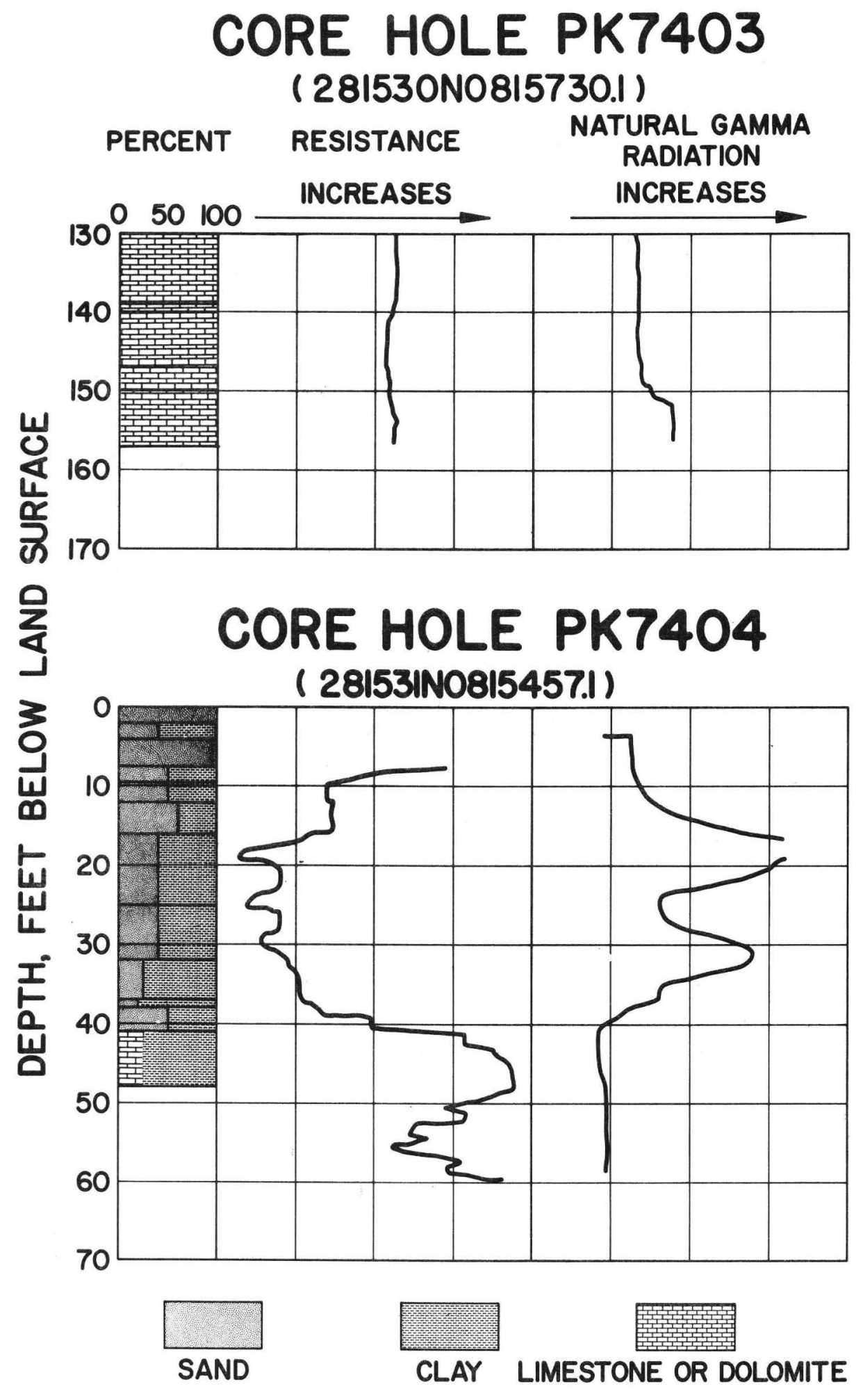


PK7406

Polk County 281819N0815202.1

DEPTH INTERVAL (feet)

$1.0-2.0$

$2.0-6.0$

$6.0-11.0$

$11.0-16.0$

$16.0-22.0$

$22.0-29.0$

$29.0-30.5$
LITHOLOGY

\section{Post Miocene Rocks}

$45 \%$ du11 yellow, stained, medium-grained, we11 sorted, sub-rounded quartz sand; 35\% light brown, indurated clay matrix; $20 \%$ dul1 yellow, stained, coarse-grained, sub-rounded quartz sand.

$70 \%$ light gray, clear to frosted, medium-grained, fairly well sorted, sub-rounded quartz sand; $10 \%$ light brown and light gray mottled, indurated, crumbly clay matrix; $20 \%$ coarse-grained sand; trace of heavy minerals and a few large foraminifera.

No sample.

Light gray, frosted, medium-grained, well sorted, well rounded quartz sand; a trace of light brown and light gray mottled, indurated clay matrix; the upper 0.4 feet of this interval contains $10 \%$ clay and $90 \%$ sand.

$65 \%$ white, clear to frosted, medium-grained, we11 sorted sub-angular to sub-rounded quartz sand; $35 \%$ very light brown, gray tinted, indurated, crumbly clay matrix; $1 / 8$ to $1 / 16$-inch bands of light purple clay from 11.8 to 13.8 feet; trace of heavy minerals.

$65 \%$ white, clear to frosted, fine-to medium-grained, sub-rounded quartz sand; $35 \%$ very light brown, indurated clay matrix; trace of heavy minerals.

$65 \%$ white, clear to frosted, fine-to very coarsegrained, angular to well rounded quartz sand; $35 \%$ light brown to very dark brown, indurated clay matrix; trace of heavy minerals.

$9.5 \%$ very pale green, soft, sticky clay matrix. $5 \%$ white, clear, fine-grained, angular, well sorted quartz. 


\section{Rocks of Miocene Age}

$30.5-33.0$

$33.0-34.0$

$34.0-39.0$

$39.0-40.0$

$40.0-41.5$

$41.5-42.0$

$42.0-44.0$

$44.0-45.0$

$45.0-48.5$

$48.5-49.5$

$49.5-50.0$
$70 \%$ white to light gray, clear to frosted, fineto medium-grained, anglular to sub-rounded quartz sand; $30 \%$ very light brown and very pale green, soft, sticky clay matrix; trace of heavy minerals.

$50 \%$ white, clear, fine-to medium-grained, angular to sub-rounded quartz sand; $50 \%$ very light pale green and white mottled, soft clay matrix; trace of heavy minerals.

Very pale green, soft, sticky, waxy clay, pockets of white and medium bluish green clay.

Clay, as above; trace of fine-grained sand, green glauconite and pyrite.

$90 \%$ medium bluish green and light pale green mottled, soft, sticky, waxy clay; a few pockets of finegrained sand; $10 \%$ sand, in pockets in the lower 0.4 feet of this interval.

$85 \%$ matrix of white, microcrystalline, soft, porous, highly weathered, dolomitic limestone. 15\% 1ight gray to medium brown, medium-grained, well sorted, sub-rounded quartz sand.

$55 \%$ light green and light tan mottled, soft, clay matrix; 45\% white and light brown, clear, mediumgrained, well sorted, sub-rounded quartz sand.

$75 \%$ very light greenish gray and bluish gray mottled, soft, sticky clay matrix; $25 \%$ clear, very fine-grained, angular, well sorted, quartz sand.

$75 \%$ 1ight greenish gray, soft, sticky, clay matrix with purple spots; $25 \%$ white and light brown, clear, medium-grained, well sorted, quartz sand; trace of heavy minerals.

$50 \%$ sand, as above; $50 \%$ light green and white mottled, indurated clay matrix.

$60 \%$ light greenish gray and light tan mottled, soft, sticky clay matrix; $40 \%$ sand, as 45.0-48.5 interval; trace of very light tan, very coarse to medium phosphate nodules; trace of heavy minerals. 
$50.0-52.5$

$52.5-77.0$

$77.0-79.0$

$79.0-82.0$
$65 \%$ medium gray, light greenish gray, creamy mottled, soft, sticky clay matrix; $25 \%$ black to brown to very light tan, fine to very coarse phosphate nodules; $7 \%$ white to light brown, clear, medium-grained, well sorted, sub-angular to sub-rounded quartz sand; $3 \%$ white, microcrystalline, indurated, chalky, porous, sandy altered limestone fragments.

No sample.

\section{Rocks of Eocene Age}

$50 \%$ light gray, light green, cream and light tan mottled, fairly well consolidated clay matrix; $40 \%$ white, light brown, clear, fine-to medium-grained, angular to sub-rounded quartz sand; $10 \%$ black to very light tan to brown, very coarse to fine phosphate nodules; trace of heavy minerals; contains Sphaerogypsina globula (Reuss), and Lepidocyclina ocalana floridana (Cushman).

Light, cream, soft, porous, fossiliferous, chalky limestone. 


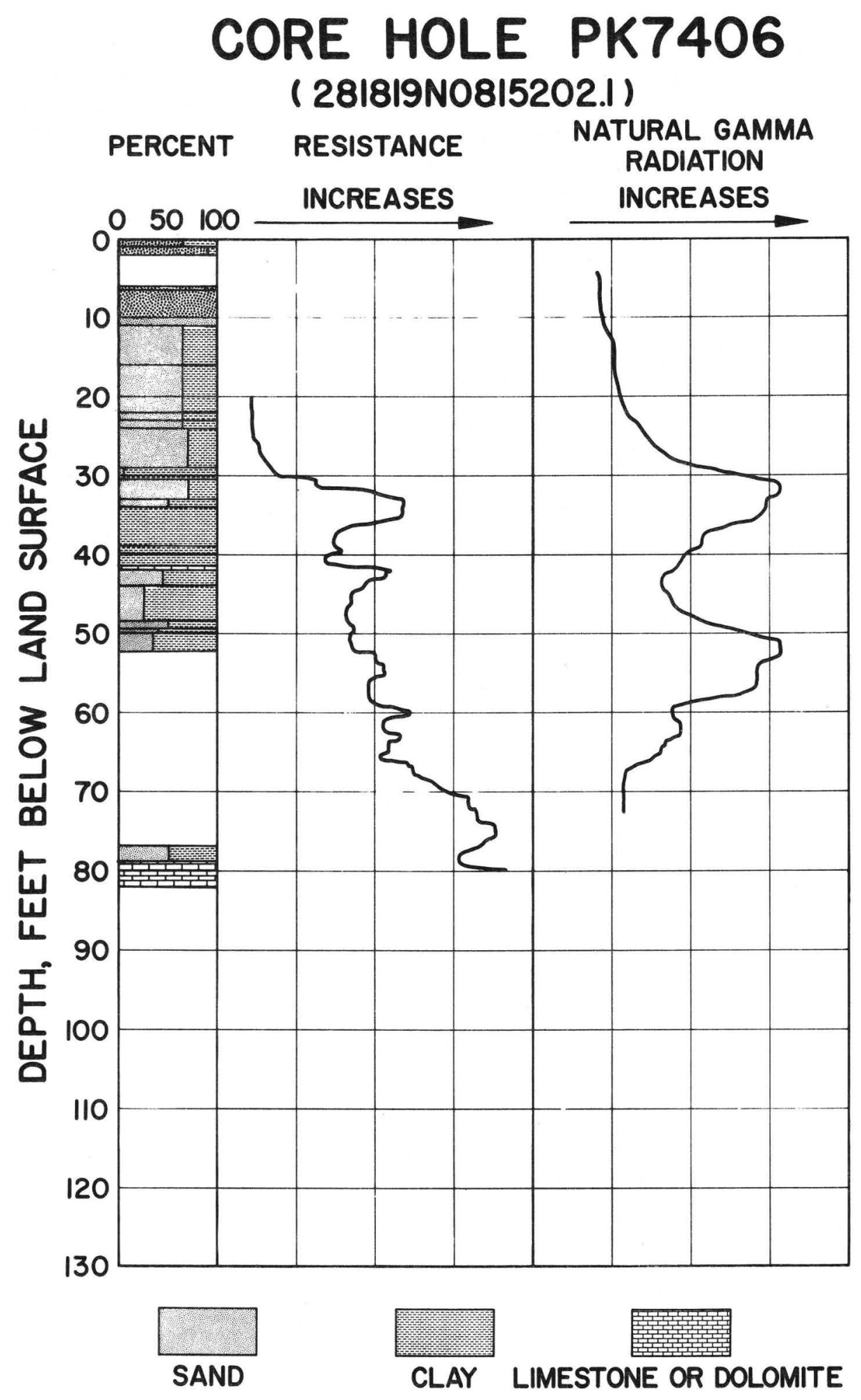


PK7407

Polk County 281843N0815011.1

DEPTH INTERVAL (feet)

$0.0-1.5$

$1.5-6.0$

$6.0-11.5$

$11.5-14.0$

$14.0-25.0$

$25.0-29.5$

$29.5-36.5$

$36.5-37.5$

$37.5-41.5$

\section{LITHOLOGY}

\section{Post Miocene Rocks}

Light brown, stained, fine-to medium-grained, angular to sub-rounded sand.

Light tan, stained, fine-to medium-grained, angular to sub-rounded sand; trace of heavy minerals.

$70 \%$ tan, stained, medium-grained, fairly well sorted, sub-angular to sub-rounded sand; $25 \%$ light orange, indurated, crumbly clay matrix; $5 \%$ coarse-grained sand.

No sample.

$60 \%$ very light tan, clear to stained, fine-to mediumgrained, angular to sub-rounded sand; $20 \%$ coarse-to very coarse-grained sand; $20 \%$ dull orange, soft clay matrix.

$75 \%$ white, clear to frosted, fine-to medium-grained, angular to well rounded quartz sand; $25 \%$ very light tan, soft, poorly consolidated clay matrix; trace of very coarse-grained sand.

$75 \%$ white, clear to frosted, fine-grained, fairly well sorted, angular quartz sand; $15 \%$ white, soft clay matrix; $10 \%$ medium-grained sand; abundant coarse and very coarse-grained sand; trace of heavy minerals and muscovite.

$80 \%$ white and light tan, clear to stained, finegrained, angular quartz sand; $15 \%$ white and du11 yellow mottled, soft clay matrix; $5 \%$ medium-to coarse-grained sand; trace of heavy minerals and medium to fine muscovite.

$75 \%$ sand, as above; $25 \%$ dull yellow with white mottled, soft clay matrix; trace of heavy minerals and muscovite. 
$41.5-50.5$

$50.5-53.5$

$53.5-56.5$

$56.5-60.0$

$60.0-63.5$

$63.5-79.0$

$75.0-79.0$

$79.0-79.2$

$79.2-82.0$
$75 \%$ fine-grained sand as 36.5-37.5 interval; $20 \%$ 1ight to dark dull yellow and white banded and mottled clay matrix; $5 \%$ medium-to very coarse-grained sand; trace of heavy minerals and fine to medium muscovite.

$65 \%$ white, clear to frosted, fine-to medium-grained, angular to rounded sand; $35 \%$ white, yellow and 1 ight brown banded, soft clay matrix; bands are 1/8-inch wide; thin $1 / 16$ to $1 / 4-$ inch bands of light green, soft, waxy clay occur throughout interval; trace of heavy minerals, fine to medium muscovite, and coarseto very coarse-grained sand.

\section{Rocks of Miocene Age}

$45 \%$ very light tan, clear to stained, fine-grained, fairly well sorted angular sand; $30 \%$ off-white and dull yellow banded and mottled, indurated clay matrix; $20 \%$ medium-grained sand; $5 \%$ coarse-grained sand; trace of heavy minerals, fine to medium muscovite, and pisolitic silica.

$55 \%$ off-white and du11 yellow mottled, indurated clay matrix; $30 \%$ white, clear to frosted, fine-to mediumgrained, angular to sub-rounded quartz sand; $15 \%$ fine to very coarse, multicolored phosphate nodules; trace of heavy minerals.

No sample.

Medium to dark brown, soft, platey, well consolidated, waxy clay matrix with off-white, soft, well consolidated silt at 64.0 to 64.4 feet, 66.1 to 66.3 feet, and 67.1 to 67.4 feet; trace of quartz sand, phosphate, and heavy minerals.

$55 \%$ light gray, clear to frosted, medium-grained, we11 sorted, sub-rounded quartz sand; $40 \%$ very light gray, indurated clay matrix; $5 \%$ brown and tan, fine-to very coarse-grained phosphate fragments and nodules.

$70 \%$ very light gray, indurated, very fine crystalline, porous dolomite matrix; $25 \%$ white, clear to frosted, medium-grained, fairly well sorted, sub-angular quartz sand; $5 \%$ fine to medium brown to tan phosphate nodules.

$70 \%$ light to medium gray mottled, soft dolomite; trace of sand and phosphate; $30 \%$ sand as above. 
$82.0-85.0$

$85.0-86.0$

$86.0-87.0$

$87.0-87.5$

$87.5-91.0$

$91.0-99.5$

$99.5-109.0$

$109.0-116.4$
$90 \%$ medium to light gray mottled, soft, very fine crystalline, dolomitic matrix; 10\% 1ight gray, clear, fine-to medium-grained, angular to sub-angular sand; trace of heavy minerals and brown to tan, fine to very coarse phosphate nodules.

$70 \%$ medium to light gray mottled, hard, very fine crystalline dolomite matrix; 20\% light gray, clear, fine-grained, angular, fairly well sorted sand; $10 \%$ black to brown, fine to very coarse phosphate fragments, nodules and phosphatic fossil fragments.

$60 \%$ dolomite, as above; $30 \%$ sand, as above; $10 \%$ phosphate, as above.

$65 \%$ light gray, hard, very fine crystalline dolomite matrix; $35 \%$ sand, as $85.0-86.0$ interval, trace of heavy minerals and black to brown, medium to very coarse phosphate nodules.

$55 \%$ sand as $85.0-86.0$ interva1; $45 \%$ light gray, soft to very fine crystalline dolomite matrix; trace of heavy minerals and black to brown, fine to coarse phosphate nodules and phosphatized fossil material.

No sample.

$60 \%$ sand, as 85.0-86.0 interval; 40\% 1ight gray, indurated, very fine crystalline dolomite matrix; trace of heavy minerals and black to brown, fine to coarse phosphate nodules.

\section{Rocks of Eocene Age}

$80 \%$ creamy, microcrystalline, hard, porous limestone, with $20 \%$ large to small fossils, highly weathered. 


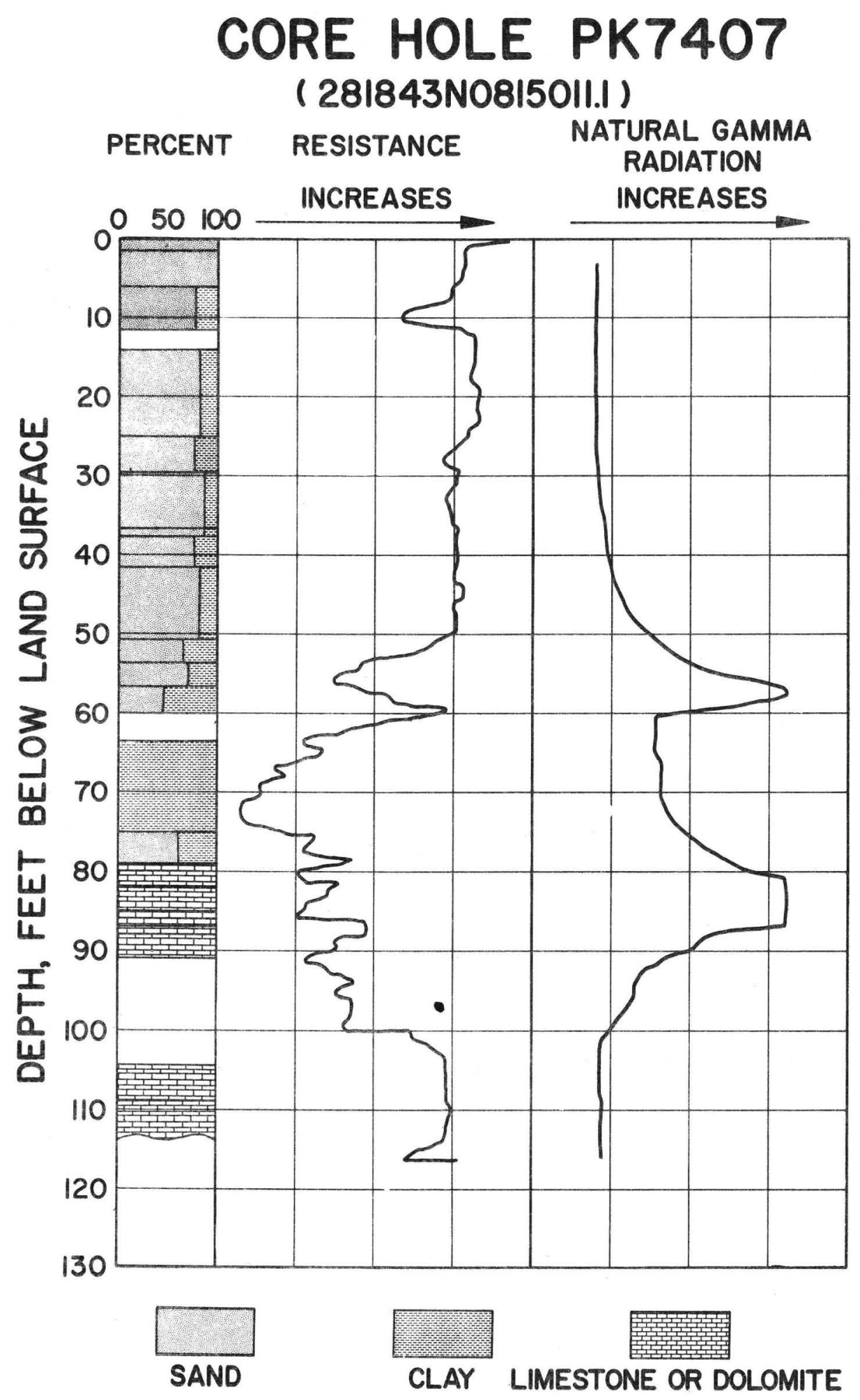


PK7408

Polk County 281809N0814651.1

DEPTH INTERVAL (feet)

$0.0-1.0$

$1.0-4.0$

$4.0-11.0$

$11.0-13.0$

$13.0-14.5$

$14 \cdot 5-21.0$

$21.0-24.5$

$24 \cdot 5-45.0$

$45.0-56.0$

\section{LITHOLOGY}

\section{Post Miocene Rocks}

95\% white to 1ight gray, clear to frosted, medium-to fine-grained, fairly well sorted, sub-rounded quartz sand; $5 \%$ coarse-grained sand; trace of medium blue clay.

95\% very light tan, clear to frosted, medium-grained, poorly sorted, sub-rounded quartz sand; $5 \%$ coarsegrained sand.

$65 \%$ white, clear to frosted, medium-grained, fairly wel1 sorted, sub-rounded quartz sand; $35 \%$ very light tan, indurated clay matrix; pink mottling from 6.0 to 6.2 feet.

$65 \%$ white, clear to frosted, medium-grained, fairly well sorted, sub-rounded quartz sand; $35 \%$ light tan and pink mottled indurated clay matrix.

$70 \%$ white, clear to frosted, fine-grained, subangular, fairly well sorted quartz sand; $30 \%$ very light tan indurated clay matrix; trace of heavy minerals.

$60 \%$ white, clear to frosted, fine-grained, poorly sorted, sub-angular quartz sand; $40 \%$ very light tan, indurated clay matrix; trace of heavy minerals.

$80 \%$ white to light gray, frosted, very coarse-to coarse-grained, rounded, fairly well sorted quartz sand; $20 \%$ off-white indurated clay matrix.

$60 \%$ white, clear to frosted, fine grained, well sorted, angular, silty sand; numerous bands of white to light gray, clear to frosted, well rounded, coarse to very coarse grained sand; bands are 1 to 2 inches wide; $40 \%$ off-white, soft clay matrix; scattered fine gravel from 37.1 to 37.4 feet; trace of heavy minerals.

$65 \%$ white, clear to frosted, fine-grained, well sorted angular quartz sand; $35 \%$ off-white, soft, silty clay matrix; trace of coarse-grained sand and heavy minerals. 
$56.0-61.0$

$61.0-72.0$

$72.0-77.0$

$77.0-91.0$

$91.0-106.0$
No sample.

$75 \%$ white, clear to frosted, fine-grained, angular, well sorted, silty quartz sand; $25 \%$ off-white, soft clay matrix; trace of heavy minerals; 68.0 to 72.0 interval is not silty.

No sample.

\section{Rocks of Miocene Age(?)}

Hard; core barrel damaged; no core recovery; interval picked on basis of high natural gamma count.

\section{Rocks of Eocene Age(?)}

No recovery; wash returned limestone cuttings; interval picked on basis of natural gamma and resistance logs. 


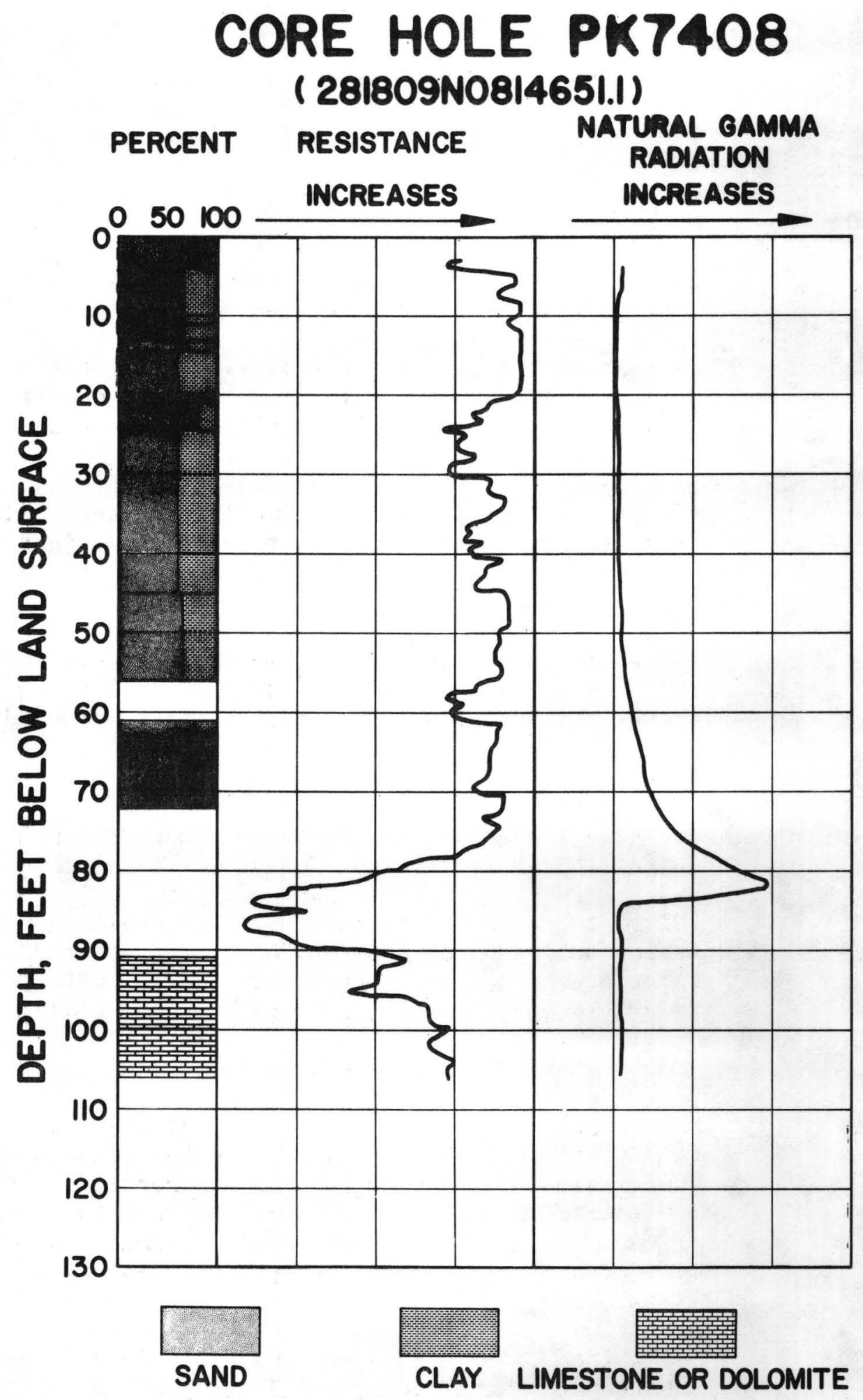


PK7409

Polk County 281530N0815228.1

DEPTH INTERVAL (feet)

$6.0-12.0$

$12.0-18.5$

$18 \cdot 5-22.0$

$22.0-24.0$

$24.0-30.0$

$30.0-35.0$

$35.0-39.0$
LITHOLOGY

\section{Post Miocene Rocks}

White, clear to frosted, fine-to medium-grained, fairly we11 sorted, sub-rounded quartz sand.

Light brown, clear to frosted, fine-to mediumgrained, fairly well sorted, sub-rounded quartz sand; just enough dark brown clay to bind sand very loosely.

$70 \%$ white, clear to frosted, medium-grained, fairly well sorted, sub-angular quartz sand; 30\% light gray and tan mottled, indurated clay; trace of heavy minerals.

$60 \%$ white, clear to frosted, medium-grained, fairly we11 sorted, sub-rounded quartz sand; $40 \%$ dark brown, soft clay matrix; trace of heavy minerals.

No sample.

$65 \%$ sand, as above; $35 \%$ light to medium brown, white mottled, soft clay matrix.

$70 \%$ white, clear to frosted, fine-to medium-grained, fairly well sorted, sub-rounded quartz sand; $30 \%$ light greenish gray, light brown and tan mottled, indurated clay matrix; trace of heavy minerals.

\section{Rocks of Miocene Age}

$65 \%$ white to light gray, fine-to medium-grained, fairly well sorted, sub-angular to sub-rounded quartz sand; $35 \%$ light gray and tan mottled, soft to indurated clay matrix; lower 0.2 foot has bands of tan, soft, waxy clay and small fragments of white, microcrystalline, indurated, porous, silicified limestone.

$50 \%$ white, clear, medium-grained, fairly well sorted, sub-rounded quartz sand; $50 \%$ light gray, soft clay matrix, mottled with light greenish gray, soft, waxy clay. 
$39.0-41.0$

$41.0-50.0$

$50.0-52.0$

$52.0-60.0$

$60.0-63.0$
$60 \%$ sand, as above; $40 \%$ light gray, soft clay matrix.

$90 \%$ tan, light greenish gray and brownish gray mottled, soft clay matrix; $10 \%$ sand as $35.0-39.0$ interval; in the lower 0.2 foot of this interval sand increases to $40 \%$, clay decreases to $60 \%$.

\section{Rocks of Eocene Age}

$60 \%$ white, clear to frosted, medium-grained, fairly well sorted, sub-rounded quartz sand; $40 \%$ light gray and tan mottled, soft, fairly well consolidated clay matrix; trace of heavy minerals and large to small fossil fragments; contains Sphaerogypsina globula (Reuss), Lepidocyclina ocalana floridana (Cushman), Cibicides mississippiensis ocalanus (Cushman), and Reussella sculptilis (Cushman).

$80 \%$ tan, soft, poorly consolidated, calcareous clay matrix; $20 \%$ light tan, microcrystalline, indurated, porous limestone; abundant fossils.

No sample. 


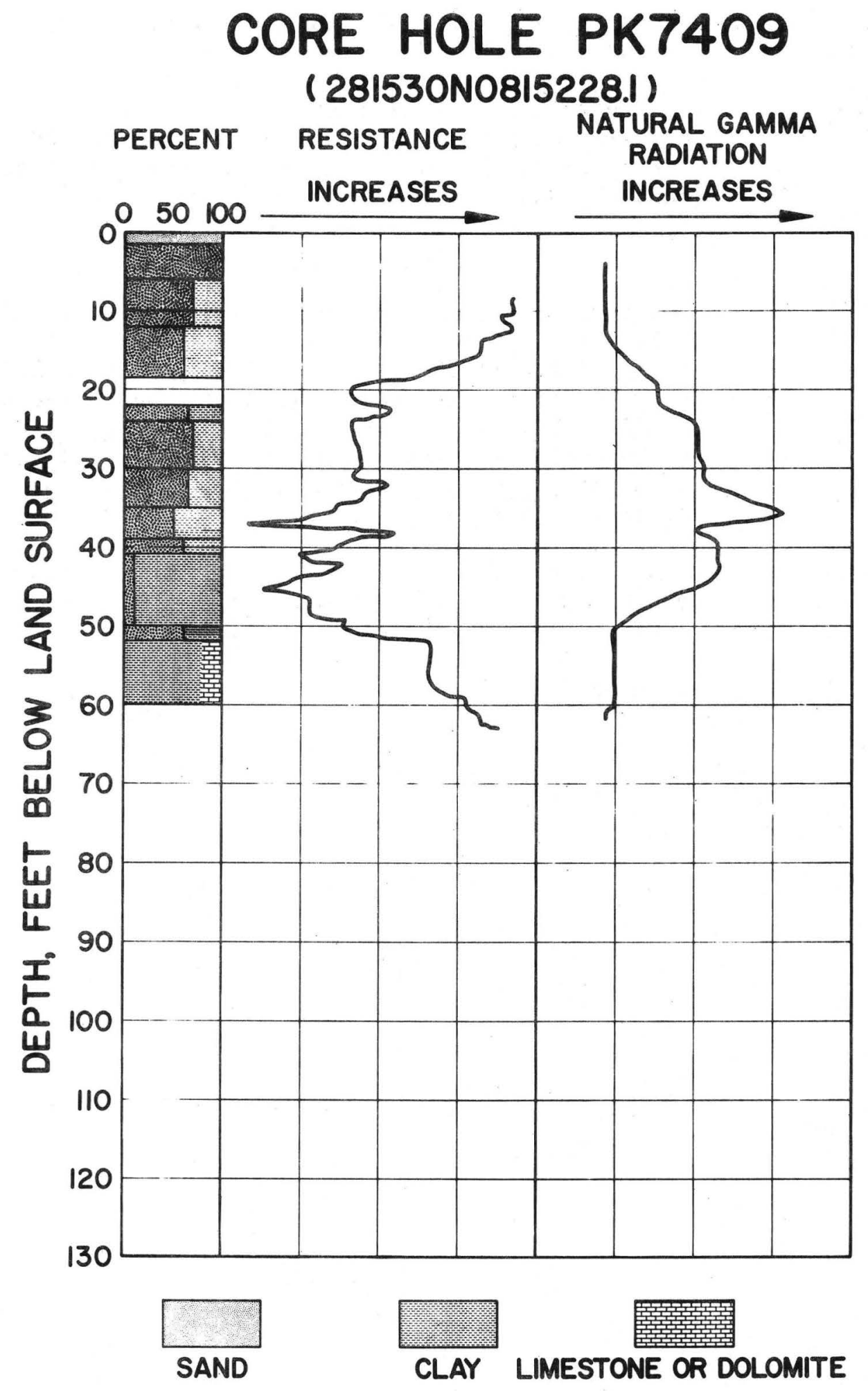


Polk County 281532N0814930.2

DEPTH INTERVAL (feet)

$0.0-1.0$

$1.0-2.0$

$2.0-6.0$

$6.0-7.0$

$7.0-8.0$

$8.0-9.0$

$9 \cdot 0-12.0$

$12.0-16.0$

$16.0-22.0$

$22.0-29.0$

$29.0-36.0$

\section{LITHOLOGY}

\section{Post Miocene Rocks}

White to light gray, clear to frosted, mediumgrained, fairly well sorted, sub-rounded quartz sand; trace of dark gray clay.

Sand, as above; trace of light brown clay.

No sample.

$60 \%$ white, frosted, medium-grained, fairly wel1 sorted, sub-rounded quartz sand; $40 \%$ medium gray, brownish gray and brown mottled, indurated clay matrix.

$50 \%$ sand, as above; $50 \%$ tan, brown and brownish gray mottled and banded indurated clay.

$50 \%$ sand, as $6.0-7.0$ interval; $50 \%$ brownish gray and medium gray banded, indurated clay matrix.

$60 \%$ sand, as $6.0-7.0$ interval; $40 \%$ medium brown indurated clay matrix.

$65 \%$ white to light gray, clear to frosted, mediumto coarse-grained, fairly well sorted, sub-rounded quartz sand; $35 \%$ medium brown, indurated clay matrix; a band of loose sand about 0.5 foot wide at 12.4 feet.

$75 \%$ light gray, clear to frosted, very coarse-to coarse-grained, well sorted, rounded quartz sand; $25 \%$ medium and light gray banded, indurated clay matrix.

$65 \%$ white, clear to frosted, coarse-to mediumgrained, poorly sorted, sub-rounded quartz sand; $35 \%$ tan and medium brown mottled, soft clay matrix.

$65 \%$ white, clear, fine-to medium-grained, fairly well sorted, sub-angular quartz sand; $35 \%$ light and dark tan, mottled, silty clay matrix. 
$36.0-48.0$

$48.0-58.0$

$58.0-63.0$

$63.0-66.0$

$66.0-83.0$
$65 \%$ sand, as above; $20 \%$ tan, soft, silty clay matrix; 15\% light gray, clear to frosted, coarseto very coarse-grained, rounded to well rounded quartz sand.

$75 \%$ white, clear, angular, fairly we11 sorted, fine grained-quartz sand; $25 \%$ light to medium tan, soft clay matrix; trace of heavy minerals, medium-grained muscovite flakes, and pisolitic silica.

\section{Rocks of Miocene Age}

$60 \%$ light gray, clear, fine-grained, fairly well sorted, angular quartz sand; $40 \%$ dark and light gray mottled, soft clay matrix; trace of heavy minerals and pisolitic silica.

$50 \%$ sand, as above; $30 \%$ brown and gray mottled, soft clay matrix; $20 \%$ light gray, dark gray, very coarse to fine phosphate nodules.

\section{Rocks of Eocene Age}

White limestone with occasional chert fragments. 


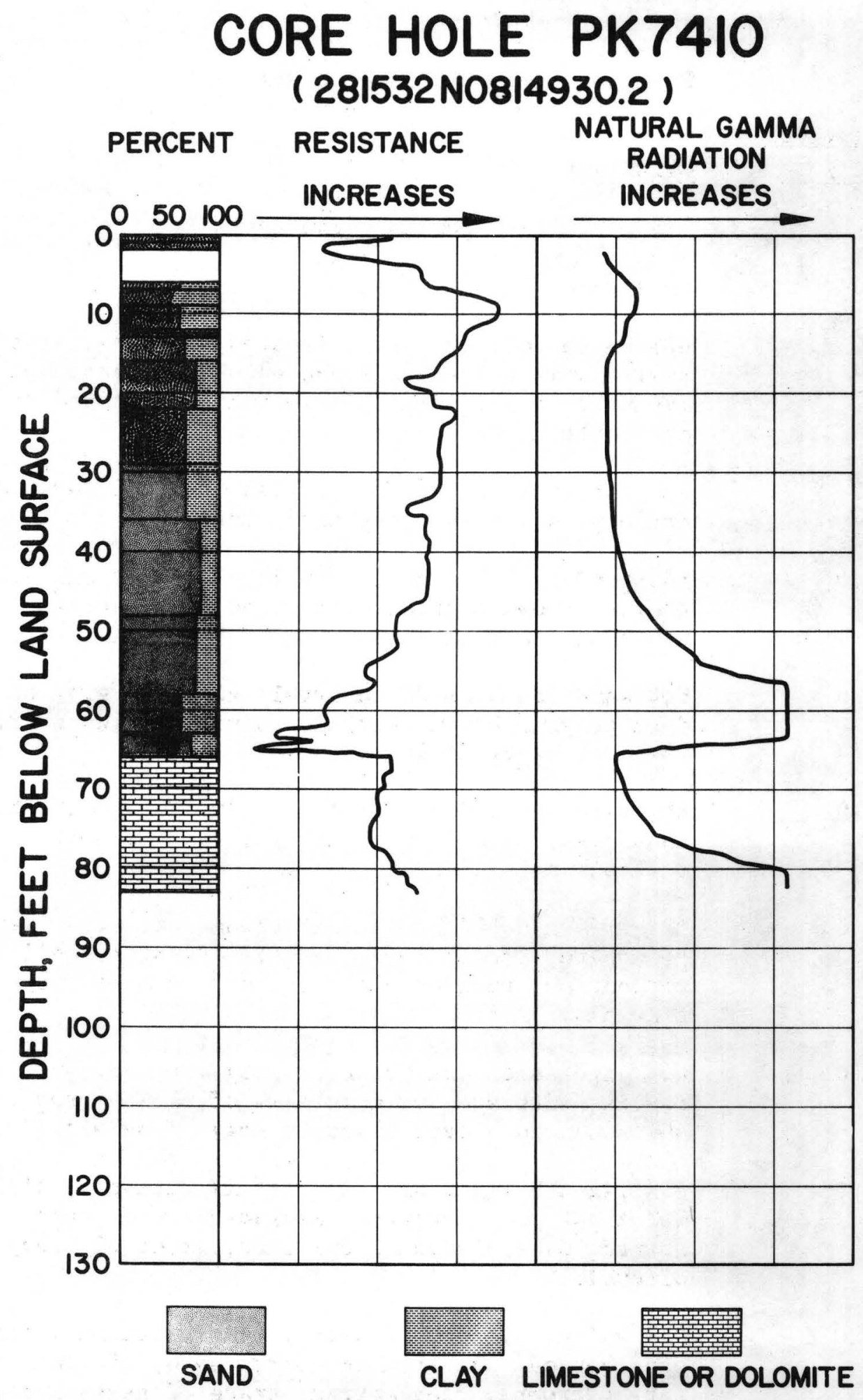


PK7411

Polk County 281629N0814620.1

DEPTH INTERVAL (feet)

$0.0-5.0$

$5.0-7.0$

$7.0-8.0$

$8.0-11.0$

$11.0-15.0$

$15.0-20.0$

$20.0-25.0$

$25.0-31.0$

$31.0-34.0$

$34.0-36.0$
LITHOLOGY

\section{Post Miocene Rocks}

No sample.

$60 \%$ white to light gray, frosted, medium-grained, fairly well sorted sub-rounded quartz sand; $40 \%$ light brown and light tan mottled, indurated crumbly clay matrix.

$70 \%$ sand, as above; $30 \%$ grayish brown, indurated, crumbly, slightly silty clay matrix.

$60 \%$ sand, as 5.0-7.0 interva1; $40 \%$ 1ight and dark grayish brown mottled, indurated clay matrix; trace of heavy minerals.

$60 \%$ sand, as 5.0-7.0 interval; $40 \%$ dark gray and dark grayish brown mottled, indurated clay matrix; trace of heavy minerals.

$80 \%$ sand, as 5.0-7.0 interval; $20 \%$ very light brown, indurated, crumbly clay matrix; becomes soft and dark brown at 18 feet.

$60 \%$ medium to light grayish brown, soft clay matrix; $40 \%$ white, frosted, medium-grained fairly well sorted, sub-rounded quartz sand; trace of heavy minerals.

$60 \%$ light and dark brownish gray mottled, soft clay matrix, with scattered streaks of bluish gray clay; $40 \%$ sand, as above; trace of heavy minerals.

$60 \%$ light brown, soft clay matrix with gray tint; $40 \%$ light gray, frosted, medium-grained, well sorted, sub-rounded quartz sand; trace of heavy minerals.

$85 \%$ white, clear to frosted, medium-grained, fairly wel1 sorted, sub-rounded quartz sand; $15 \%$ tan, indurated, crumbly clay matrix; trace of heavy minerals. 
$36.0-45.0$

$45.0-50.0$

$50.0-65.0$

$65.0-68.0$

$68.0-76.0$

$76.0-80.0$

$80.0-97.0$

$97.0-107.0$

$107.0-114.0$

$114.0-118.0$
$90 \%$ white, clear to frosted, very fine-to very coarsegrained, angular to well rounded, silty quartz sand; $10 \%$ indurated clay matrix.

$75 \%$ white, clear to frosted, fine-to very finegrained, angular to well rounded, silty quartz sand; $25 \%$ 1ight tan, soft, poorly consolidated clay matrix.

$75 \%$ sand, as above, but contains some very coarsegrained sand; $25 \%$ tan, soft clay matrix.

No sample.

$70 \%$ white, clear, fine-grained, well sorted, angular, silty quartz sand; $25 \%$ tan, indurated clay matrix; $5 \%$ light gray, frosted, well rounded, coarse-to very coarse-grained sand; trace of heavy minerals.

No sample.

$70 \%$ 1ight gray, frosted to clear, fine-grained, very well sorted, angular, silty quartz sand; $30 \%$ light and medium greenish gray, mottled, soft clay matrix; beginning at 89.9 feet, clay is dark greenish gray and has no mottling; trace of heavy minerals.

$60 \%$ dark gray and dark brown mottled, soft sticky clay matrix; 40\% light gray, clear, fine-to mediumgrained, angular to sub-rounded quartz sand.

$50 \%$ dark gray and medium greenish gray, banded and mottled, soft clay matrix; $30 \%$ light gray, clear to frosted, fine-grained, fairly well sorted, angular, silty, quartz sand; $20 \%$ white to light gray, clear to frosted, rounded, medium-grained quartz sand; sand increases to $70 \%$, clay decreases to $30 \%$ between 109.0 and 111.0 feet.

\section{Rocks of Eocene Age}

$65 \%$ highly weathered fragments of very light gray, microcrystalline, indurated, porous limestone; $35 \%$ fossils and fossil fragments. 


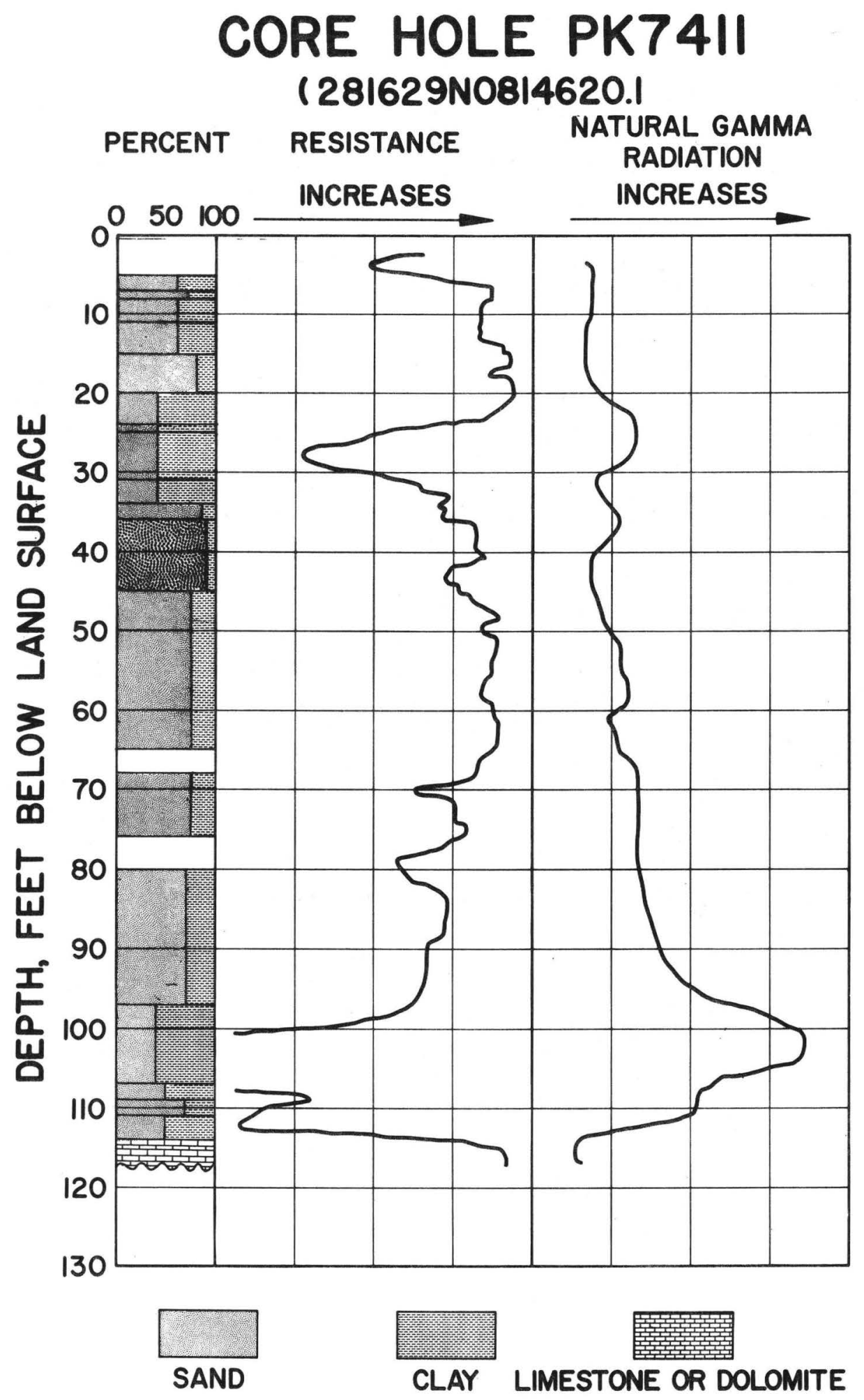


PK7412

Polk County 281823N0814406.1

DEPTH INTERVAL (feet)

$0.0-2.0$

$2 \cdot 0-4 \cdot 0$

$4.0-6.0$

$6.0-8.5$

$8.5-14.5$

$14.5-15.5$

$15.5-19.5$

$19.5-21.5$

$21.5-26.5$

$26.5-28.5$

$28.5-31.5$

$31.5-36.5$

$36.5-37.0$

\section{LITHOLOGY}

\section{Post Miocene Rocks}

Light brown, stained, medium-to coarse-grained, rounded to sub-rounded sand.

Light tan, clear to stained, medium-to coarsegrained, sub-rounded to rounded sand.

No sample.

$60 \%$ white, clear to frosted, medium-grained, fairly we11 sorted, sub-rounded sand; $40 \%$ off-white indurated, powdery clay matrix.

No sample.

$55 \%$ very light tan, clear to stained, medium-grained, sub-rounded sand; $35 \%$ off-white, indurated, powdery clay matrix; $10 \%$ coarse-grained sand.

$65 \%$ white, frosted, medium-to very coarse-grained, rounded sand; $35 \%$ white and off-white, indurated, crumbly, slightly silty clay matrix.

No sample.

$50 \%$ white, clear to frosted, fine-grained, angular, well sorted sand; 40\% creamy, indurated to soft, silty clay matrix; $10 \%$ coarse-to very coarse-grained sand.

No sample.

$55 \%$ sand, as $21.5-26.5$ interva1; $40 \%$ creamy, indurated to soft, silty clay matrix; $5 \%$ coarse-to very coarse-grained sand.

No sample.

$35 \%$ coarse-to very coarse-grained sand, as 28.531.5 interval; $35 \%$ creamy, indurated, silty clay matrix; $30 \%$ fine-grained sand. 


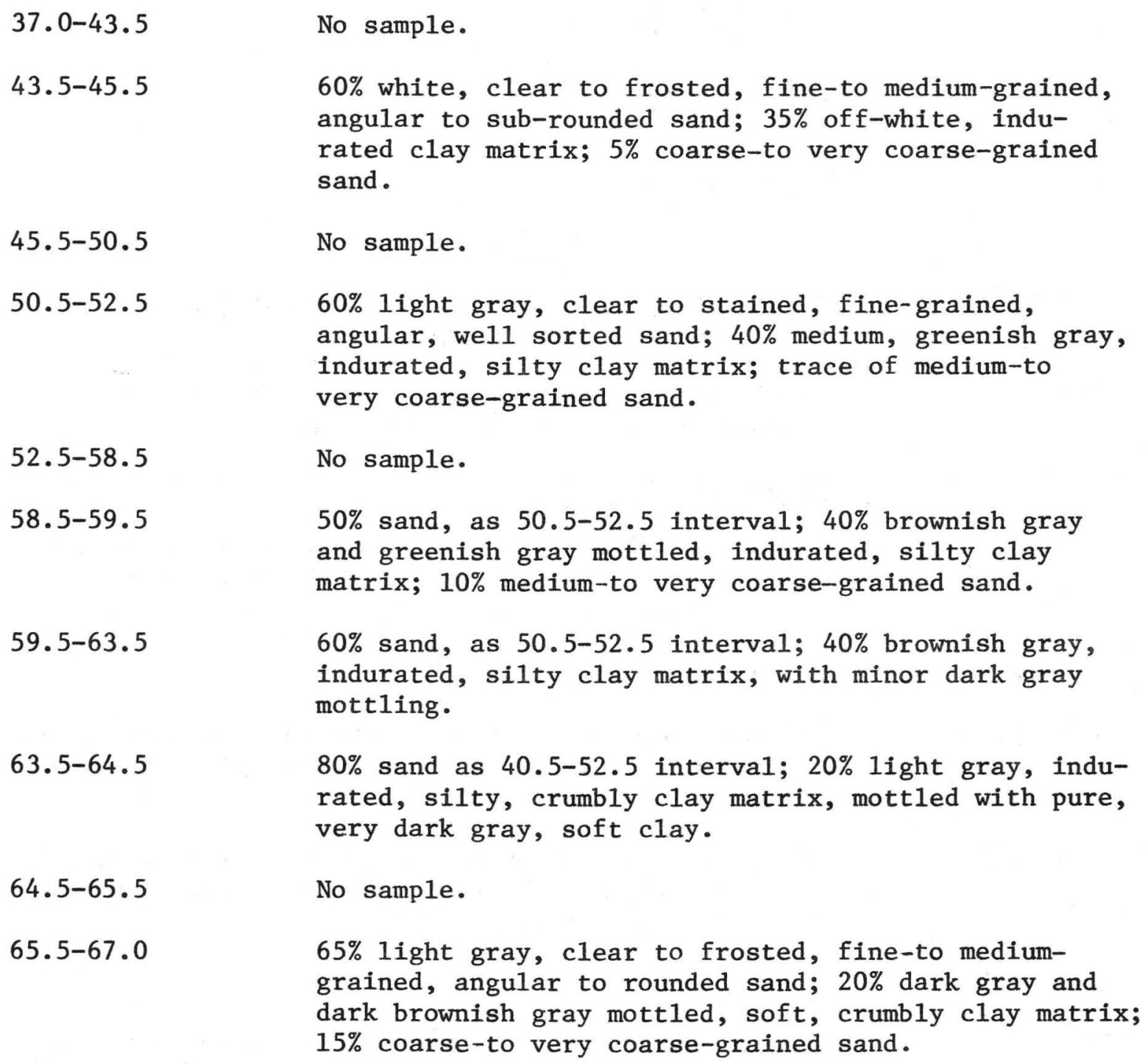

\section{Rocks of Eocene Age}

$67.0-68.5$

$50 \%$ high1y weathered fragments of 1ight gray, very fine-grained, indurated, porous limestone. 50\% large to small foraminifera and other fossils.

$68.5-74.5$

$50 \%$ high1y weathered, 1ight brown, microcrystalline, indurated, porous limestone; 50\% large foraminifera; contains Dictyoconus sp., Flintina avonparkensis (Applin and Jordan), Lituonella floridana (Cole), and Valvulina floridana (Cole).

74.5-102.0 No sample. 


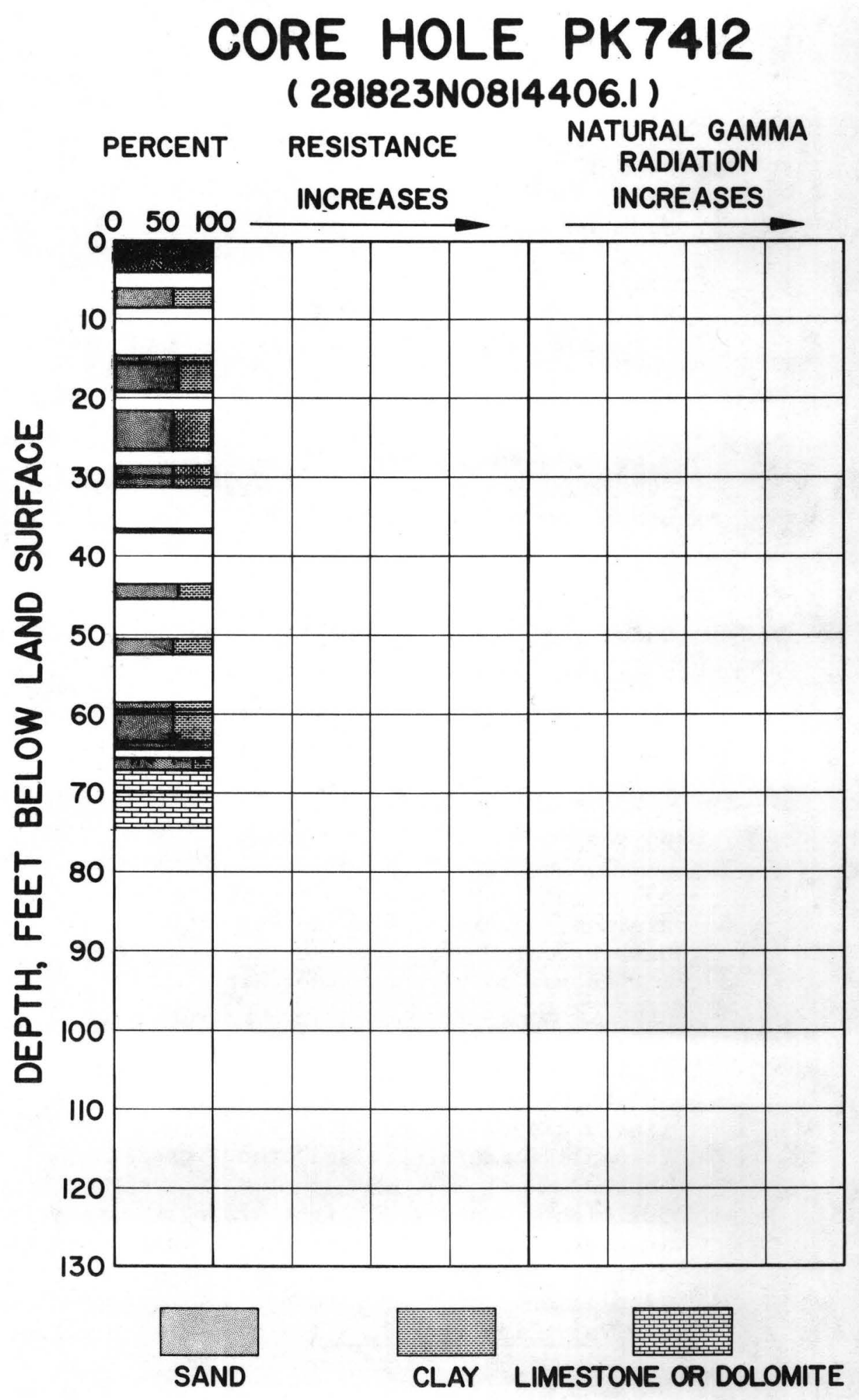


PK7413

Polk County 281836N0814053.1

DEPTH INTERVAL

(feet)

$0.5-3.0$

$3.0-6.0$

$6.0-12.0$

$12.0-13.5$

$13.5-14.5$

$14 \cdot 5-19 \cdot 5$

$19 \cdot 5-20.0$

$20.0-21.0$
LITHOLOGY

\section{Post Miocene Rocks}

$80 \%$ white to light brown, clear to stained, mediumgrained, fairly well sorted, sub-rounded quartz sand; $20 \%$ coarse-grained sand; trace of heavy minerals and just enough medium brown clay to bind the sand very loosely.

$90 \%$ sand as above; $10 \%$ coarse-grained sand; trace of heavy minerals.

No sample.

White to light tan, clear to frosted, mediumgrained, fairly well sorted, sub-rounded quartz sand; just enough white, light tan and pink mottled clay to bind sand very loosely; trace of heavy minerals.

$75 \%$ white and 1ight brown, clear to frosted, mediumto coarse-grained, sub-rounded quartz sand; $25 \%$ dull orange, soft, crumbly clay matrix; trace of heavy minerals.

$70 \%$ white to pink to yellow, frosted and stained, coarse-grained, sub-rounded quartz sand; $30 \%$ dull orange, dul1 yellow and white mottled indurated crumbly clay matrix; trace of heavy minerals.

$85 \%$ white, clear to frosted, coarse-to mediumgrained, rounded quartz sand; $15 \%$ pink, indurated, crumbly clay matrix.

$40 \%$ white to yellow to orange, clear to stained, coarse-grained quartz sand; $40 \%$ medium-grained, subrounded quartz sand; $20 \%$ dul1 orange and dul1 yellow mottled, indurated crumbly clay matrix.

$85 \%$ sand, as above; $15 \%$ du11 yellow, indurated, fully consolidated, crumbly clay matrix. 
$21.0-27.0$

$27.0-29.0$

$20 \simeq 21.0$

$31.0-31.5$

$31.5-32.5$

$32.5-36.0$

$36.0-42.0$

$42.0-45.0$

$45.0-49.0$

$49.0-54.5$

$54.5-60.0$

$60.0-68.0$
$80 \%$ very 1 ight gray, clear to frosted, coarse-to very coarse-grained, well sorted, sub-rounded quartz sand; $20 \%$ white and very light pink mottled, indurated, crumbly clay matrix.

No sample.

$80 \%$ white, frosted, coarse-to medium-grained, subrounded quartz sand, $20 \%$ off-white, tan and du11 yellow mottled, indurated, crumbly clay matrix; trace of heavy minerals.

$95 \%$ sand, as above; $5 \%$ very light tan and dull yellow mottled, indurated, crumbly clay matrix; trace of heavy minerals.

$90 \%$ sand, as $29.0-31.0$ interval; $10 \%$ very light tan, soft, poorly consolidated, crumbly clay matrix.

$65 \%$ white, clear to frosted, medium-grained, fairly well sorted, sub-rounded quartz sand; $25 \%$ white, indurated, crumbly, powdery clay matrix; 10\% light gray, frosted, very coarse-to coarse-grained, subrounded quartz sand.

No sample.

$75 \%$ white, frosted, medium-grained, fairly wel1 sorted, sub-rounded quartz sand; $10 \%$ white and tan mottled, indurated, crumbly clay matrix; 15\% light gray, frosted, coarse-grained, sub-rounded quartz sand, trace of heavy minerals.

$70 \%$ sand, as above; $30 \%$ tan and white mottled, soft, poorly consolidated clay matrix; trace of heavy minerals.

No sample.

$40 \%$ 1ight gray, clear, medium-to coarse-grained, rounded quartz sand; $35 \%$ white, clear, fine-grained, we11 sorted, sub-angular, quartz sand; $25 \%$ very light tan, soft clay matrix; trace of heavy minerals.

$85 \%$ sand, as above; $15 \%$ clay, as above; trace of heavy minerals. 
$68.0-71.0$

$71.0-75.0$

$75.0-80.0$

$80.0-83.0$

$83.0-87.0$

$87.0-90.0$

$90.0-93.0$

$93.0-95.0$

$95 \cdot 0-100.0$
$80 \%$ sand, as $54.5-60.0$ interva1; $20 \%$ very light gray and slight tan mottled, indurated, crumbly clay matrix; trace of heavy minerals.

$85 \%$ white, clear to frosted, medium-grained, fairly we11 sorted, sub-angular quartz sand; $15 \%$ tan, indurated, poorly consolidated, crumbly clay matrix; trace of heavy minerals.

95\% white, clear to frosted, coarse-to medium-grained, sub-rounded quartz sand; $5 \%$ very light tan, soft, crumbly clay matrix; trace of heavy minerals.

\section{Rocks of Miocene Age}

$70 \%$ white, clear, fine-grained, angular, well sorted, quartz sand; $30 \%$ very pale greenish gray, soft, silty clay matrix; trace of coarse-grained sand and heavy minerals.

$60 \%$ white, clear, fine grained, angular to well sorted quartz sand; $40 \%$ light greenish gray, soft, silty clay matrix; trace of coarse-grained sand, heavy minerals and black to tan fine to very coarse phosphate nodules and blades.

$50 \%$ sand, as above; $50 \%$ light green, soft, silty, clay matrix; trace of phosphate and heavy minerals.

\section{Rocks of Eocene Age}

Fragments of light cream colored microcrystalline, indurated, porous limestone; $60 \%$ matrix of off-white indurated, calcareous highly weathered limestone clay; $40 \%$ large to small fossils; trace of sparry calcite replacement.

$90 \%$ microcoquina; $10 \%$ light gray, microcrystalline, indurated, porous limestone matrix.

$60 \%$ very light gray, microcrystalline, indurated, porous, limestone matrix; $40 \%$ fossils and fossiliferous materials, highly weathered and crumbly. 


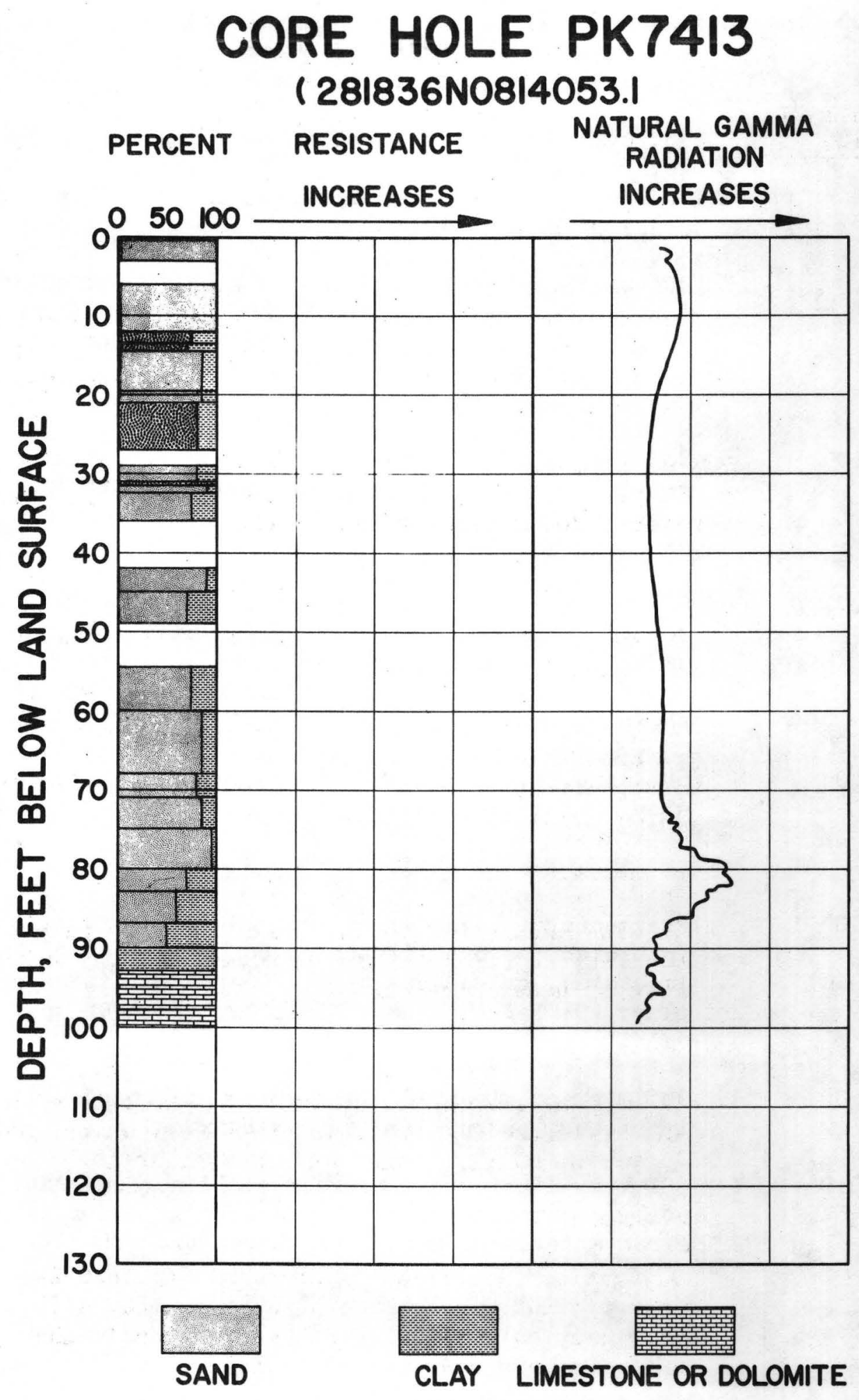


PK7414

Polk County 281524N0814227.1

DEPTH INTERVAL (feet)

$0.0-6.0$
$6.0-6.5$
$6.5-7.5$
$7.5-9.5$
$9.5-16.0$

$16.0-22.5$

$22.5-26.5$

$26.5-29.5$

$29.5-33.5$

$33.5-40.5$

$40.5-43.5$

$43.5-47.5$
LITHOLOGY

\section{Post Miocene Rocks}

No sample.

$40 \%$ light gray, frosted, coarse-to very coarsegrained, rounded quartz sand; $40 \%$ brownish gray, indurated, crumbly clay matrix; $20 \%$ fine-to mediumgrained sand.

$40 \%$ sand, as above, but is now white in color; $40 \%$ very pale, cream colored, soft, crumbly clay matrix; $20 \%$ medium-grained sand.

No sample.

$70 \%$ sand, as $6.5-7.5$ interval; $30 \%$ light brown indurated, crumbly clay matrix.

$75 \%$ white, clear to frosted, very coarse-to finegrained, angular to rounded quartz sand; $25 \%$ offwhite to very pale tan, indurated, crumbly, silty clay matrix; trace of heavy minerals.

No sample.

$85 \%$ sand, as $16.0-22.5$ interval; $15 \%$ very pale tan to off-white, soft to indurated, silty clay matrix; trace of heavy minerals.

No sample.

$60 \%$ sand as $16.0-22.5$ interval, but most fine-to very fine-grained; $40 \%$ very pale tan to off-white, soft, silty clay matrix; trace of heavy minerals.

No sample.

$60 \%$ fine-to very fine-grained sand, as 16.0-22.5 interval; $40 \%$ very pale tan to off-white, soft, silty clay matrix; trace of heavy minerals and coarse-to very coarse-grained sand. 
$47.5-49.5$

$49.5-51.0$

$51.0-55.0$

$55.5-57.5$

$57.5-58.5$

$58.5-65.0$

$65.0-66.5$

$66.5-70.5$

$70.5-71.0$

$71.0-72.0$

$72.0-82 \cdot 0$
No sample.

$70 \%$ sand, as $16.0-22.5$ interval; $30 \%$ very light tan, soft, silty clay matrix; trace of heavy minerals.

No sample.

$55 \%$ sand, as $16.0-22.5$ interval; $45 \%$ light tan, soft, silky clay matrix; a 1-inch band of coarse-to very coarse-grained quartz sand at 56.8 feet; trace of heavy minerals.

$60 \%$ sand, as 16.0-22.5 interval; 40\% light brownish gray, soft, silty clay matrix.

$55 \%$ light gray, clear to frosted, very fine-to finegrained, angular, very well sorted quartz sand; $45 \%$ medium gray, soft, silty clay matrix; trace of coarseto very coarse-grained sand.

No sample.

$50 \%$ medium brownish gray and medium greenish gray banded and mottled soft, silty clay matrix; $45 \%$ light brown, clear to stained, very fine-to finegrained, angular, very we11 sorted quartz sand; $5 \%$ medium-to very coarse-grained quartz sand; trace of heavy minerals and marcasite.

\section{Rocks of Miocene Age}

$80 \%$ black, light brown and light tan banded and mottled, soft, silty, crumbly clay matrix; $20 \%$ white, clear, very fine-to fine-grained, angular, well sorted sand; trace of black to brown, medium to very coarse phosphate nodules, coarse-to very coarse-grained sand.

\section{Rocks of Eocene Age}

$60 \%$ light tan, very fine-grained, soft, porous limestone fragments; $40 \%$ large to small foraminifera, highly weathered.

$50 \%$ light gray, microcrystalline, hard, porous, limestone fragments; $50 \%$ large to small foraminifera and other fossils, highly weathered; contains Camerina sp. and Lepidocyclina ocalana floridana (Cushman). 


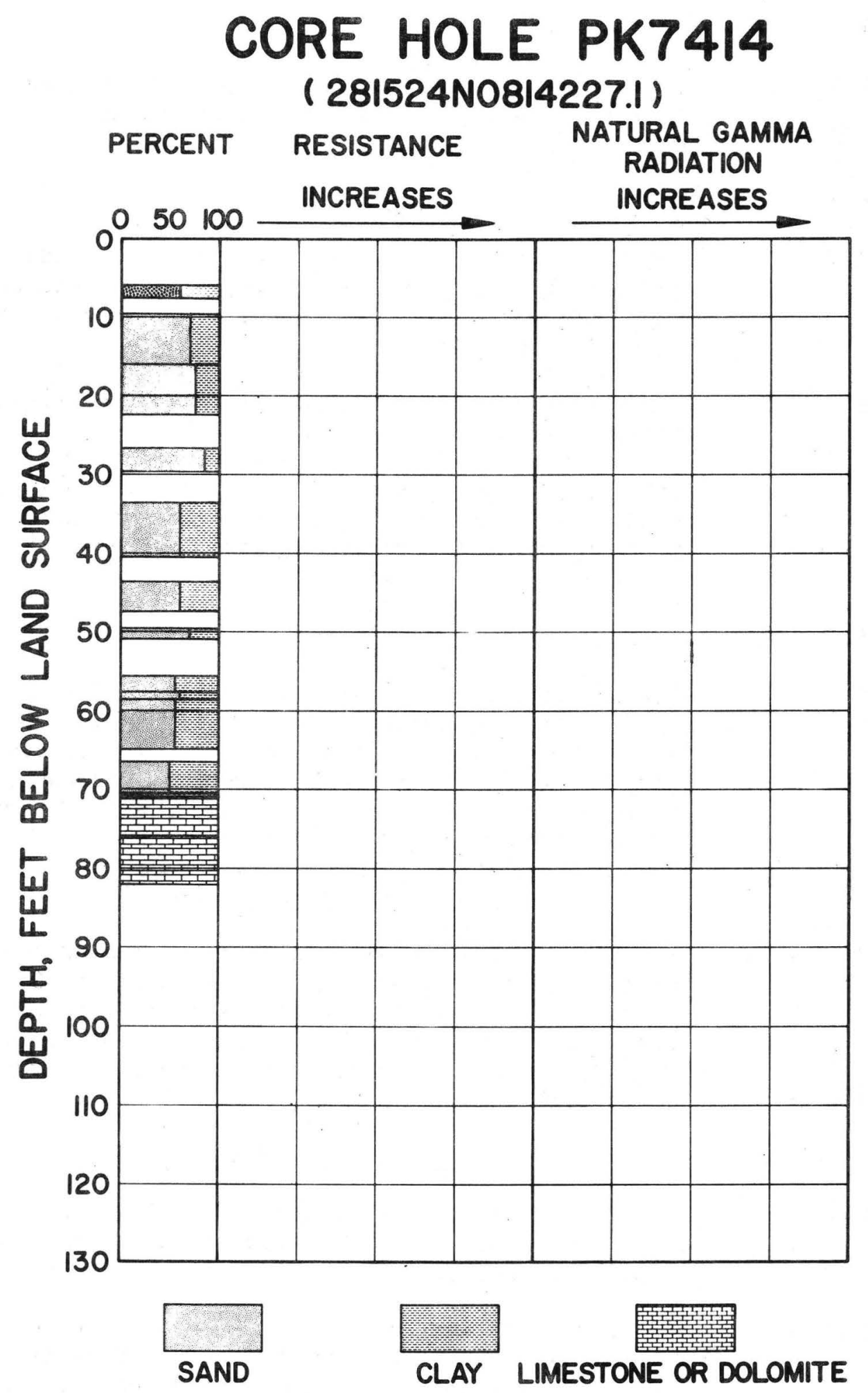


PK7415

Polk County 281512N0814017.1

DEPTH INTERVAL (feet)

$2.5-3.0$

$3.0-6.0$

$6.0-7.0$

$7.0-8.0$

$8.0-15.5$

$15.5-16.5$

$16.5-17.5$

$17.5-20.5$

$20.5-21.5$

$21.5-22.5$

\section{LITHOLOGY}

\section{Post Miocene Rocks}

Light gray to orange, clear to stained, fine-to coarse-grained, angular to rounded quartz sand; trace of light brown clay.

$75 \%$ 1ight gray, clear to frosted, fine-to mediumgrained quartz sand; $25 \%$ light brown and dark gray mottled, soft, poorly consolidated clay matrix.

White, clear to frosted, medium-grained, fairly well sorted, sub-rounded sand.

No sample.

$50 \%$ white to dark brown, clear to stained, mediumgrained, fairly we11 sorted, sub-rounded sand; $50 \%$ very dark brown to very dark grayish brown, soft, clay matrix.

$50 \%$ sand, as above; $50 \%$ medium brown, soft, clay matrix.

No sample.

$70 \%$ very light tan, medium-grained, clear to frosted, fairly well sorted, sub-angular to sub-rounded sand; $30 \%$ light to dark brown, soft clay matrix.

$85 \%$ light brown, stained, medium-grained, well sorted, sub-rounded sand; $15 \%$ dark gray and dark brown soft clay matrix.

No sample.

$65 \%$ white, clear to frosted, medium-grained, fairly we11 sorted, sub-rounded sand; $35 \%$ light brown, indurated clay matrix; trace of heavy minerals.

$50 \%$ sand, as above; $50 \%$ very light, cream colored, soft clay matrix; trace of heavy minerals. 
22.5-27.5 No sample.

27.5-27.7 Same as 21.5-22.5 interval.

27.7-28.7 50\% white, clear to frosted, fine-to medium-grained, sub-angular quartz sand; $50 \%$ very light cream colored, indurated clay matrix; a few streaks of medium brown and bluish gray clay; trace of heavy minerals.

$28.7-30.0$

$80 \%$ light brown, soft, waxy clay matrix; $20 \%$ sand, as above; a 1-inch band of white, fine-to mediumgrained, fairly well sorted sand at 29.5 feet.

$30.0-30.5$

$50 \%$ off-white, very fine-grained, indurated, porous, vuggy, limestone fragments; $50 \%$ light gray, clear to frosted, medium-grained, fairly well sorted, subrounded sand.

$30.5-32.5$

$90 \%$ white, clear, fine-to medium-grained, subangular quartz sand; $10 \%$ very light tan, soft, poorly consolidated clay matrix; trace of heavy minerals.

$32.5-39.5$

No sample.

$39.5-40.5$

$80 \%$ sand, as $30.5-32.5$ interval; $20 \%$ very light tan and light brown mottled, soft clay matrix.

$40.5-50.0$

No sample.

$50.0-54.5$

$75 \%$ white, clear to frosted, fine-grained, angular, well sorted quartz sand; $25 \%$ off-white to very light gray, soft, silty clay matrix; trace of heavy minerals.

54.5-65.5 No sample.

65.5-66.5 $70 \%$ sand, as $50.0-54.5$ interva1; $30 \%$ very light tan, soft clay matrix; trace of heavy minerals.

$66.5-67.0$

$75 \%$ white, clear to frosted, fine-to medium-grained, angular to sub-rounded quartz sand; $25 \%$ tan, soft clay matrix; trace of heavy minerals.

$67.0-69.5$

$75 \%$ white to very light tan, clear to frosted, finegrained, angular, well sorted sand; $25 \%$ light brown, soft, silty clay matrix; trace of heavy minerals and fine muscovite. 
$69.5-71.5$

$71.5-72.5$

$72.5-73.5$

$73.5-73.6$

$73.6-76.5$

$76.5-78.5$

$78.5-80.0$

$80.0-84.5$

$84.5-86.5$

$86.5-90.5$

$90.5-91.5$

$91.5-92.5$

$92 \cdot 5-104.4$
No sample.

$75 \%$ sand, as 67.5-69.5 interva1; 25\% light brown, gray tinted, soft clay matrix; trace of coarse-to very coarse-grained sand.

$85 \%$ white to light gray, clear to frosted, mediumgrained, fairly well sorted, sub-angular sand; $15 \%$ white and light grayish brown mottled, soft clay matrix; trace of heavy minerals.

$65 \%$ white, clear to frosted, very fine-to finegrained, angular, we11 sorted sand; $35 \%$ light brown and light tan mottled, soft clay matrix; trace of fine-grained muscovite, heavy minerals and black to gray medium phosphate nodules.

$60 \%$ sand, as above; $40 \%$ light brown, soft, silty, clay matrix; trace of muscovite and heavy minerals.

No sample.

Same as 73.6-76.5 interval, but clay is light tan; several 1-inch bands of grayish brown, soft, well consolidated, waxy clay in lower 0.5 foot.

$50 \%$ sand, as $73.5-73.6$ interval; $50 \%$ interbedded, light grayish brown and medium gray, soft, silty clay matrix; trace of muscovite and heavy minerals.

No sample.

\section{Rocks of Miocene Age}

$50 \%$ bluish green and greenish gray mottled, soft, silty clay matrix with tan and medium gray mottling in lower 2 feet; $35 \%$ white to light gray, clear to frosted, fine-grained, angular, well sorted quartz sand; $15 \%$ coarse-to very coarse-grained sand; trace of heavy minerals and black to buff to brown, medium to very coarse phosphate nodules.

$65 \%$ sand, as above; $35 \%$ clay, as above.

\section{Rocks of Eocene Age}

Very light gray to off-white, microcrystalline, indurated, porous, limestone fragments with fossiliferous material, highly weathered.

No sample. 


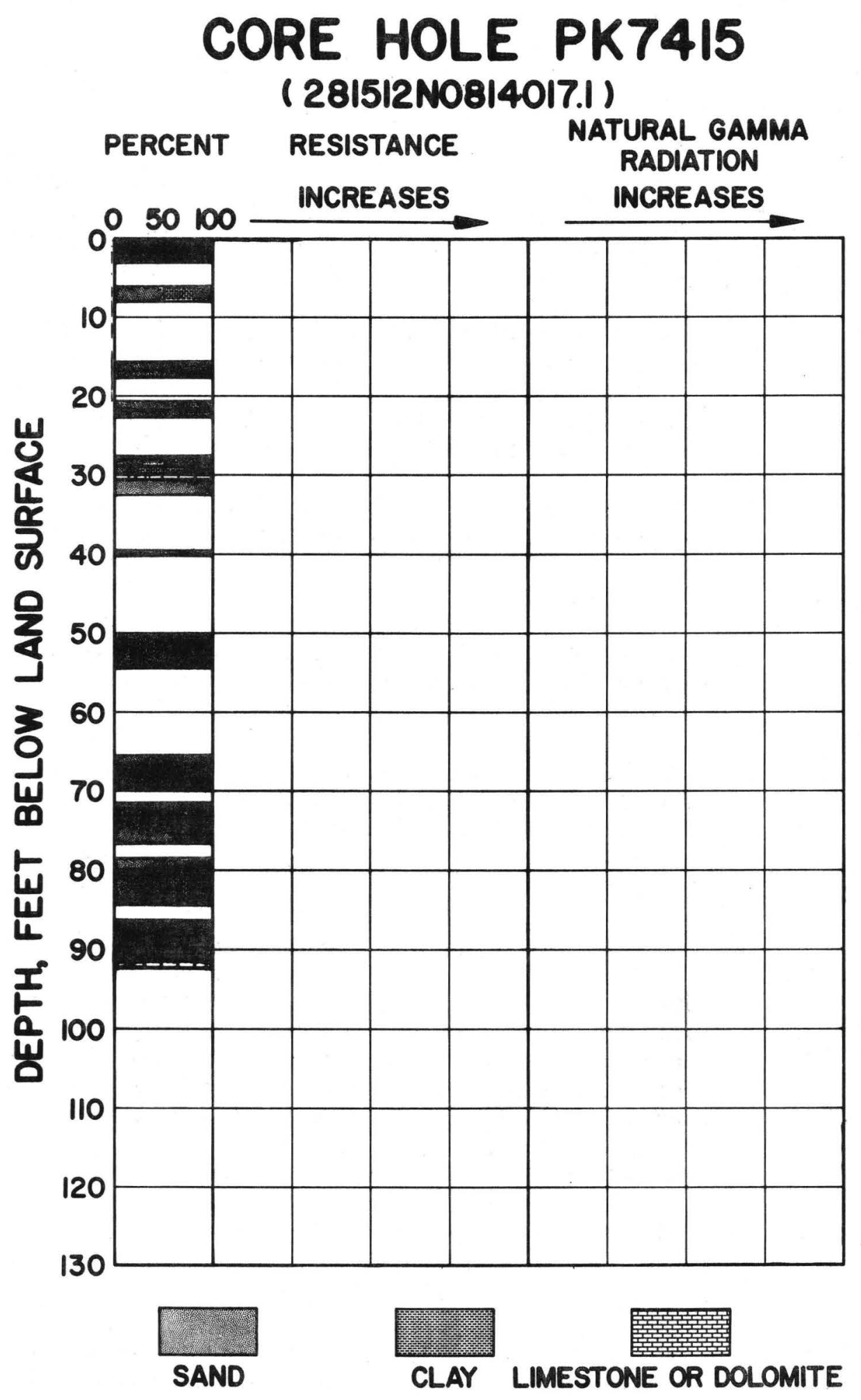


PK7416

Polk County 281859N0814209.1

DEPTH INTERVAL (feet)

$1.0-3.0$

$3.0-6.0$

$6.0-8.0$

$8.0-8.5$

$8.5-11.5$

$11.5-13.0$

$13.0-14.5$

$14 \cdot 5-17.5$

$17.5-23.5$

$23.5-24.0$

\section{LITHOLOGY}

\section{Post Miocene Rocks}

95\% white to tan, clear to frosted, medium-grained, we11 sorted, sub-angular sand; $5 \%$ light brown and light gray mottled, soft clay matrix.

95\% sand, as above; 5\% light brown and light tan mottled, soft clay matrix.

No sample.

55\% dark red, stained, white and tan frosted, medium-grained, well sorted, sub-angular to subrounded sand; $45 \%$ brick red, medium brownish gray and dull yellow banded, indurated clay matrix.

$50 \%$ white to light brown, frosted, medium-grained, well sorted, sub-rounded sand; $50 \%$ medium brownish gray, indurated clay matrix.

No sample.

$35 \%$ white, clear, fine-grained, we11 sorted, subangular sand; $35 \%$ medium brown, indurated clay matrix; $30 \%$ medium-to coarse-grained sand; trace of heavy minerals.

$85 \%$ light brown and medium brown, mottled, indurated, silty, waxy clay matrix; $15 \%$ white, clear to frosted, fine-to medium-grained, fairly well sorted, subangular to sub-rounded sand; trace of medium-grained glauconite pellets.

No sample.

$80 \%$ buff, silty, indurated clay matrix with scattered pockets of dark brown, indurated waxy clay; $20 \%$ sand as $13.0-14.5$ interval.

$70 \%$ white, clear to frosted, fine-to medium-grained, sub-angular to sub-rounded sand; $30 \%$ light to dark brown, indurated, waxy clay matrix. 


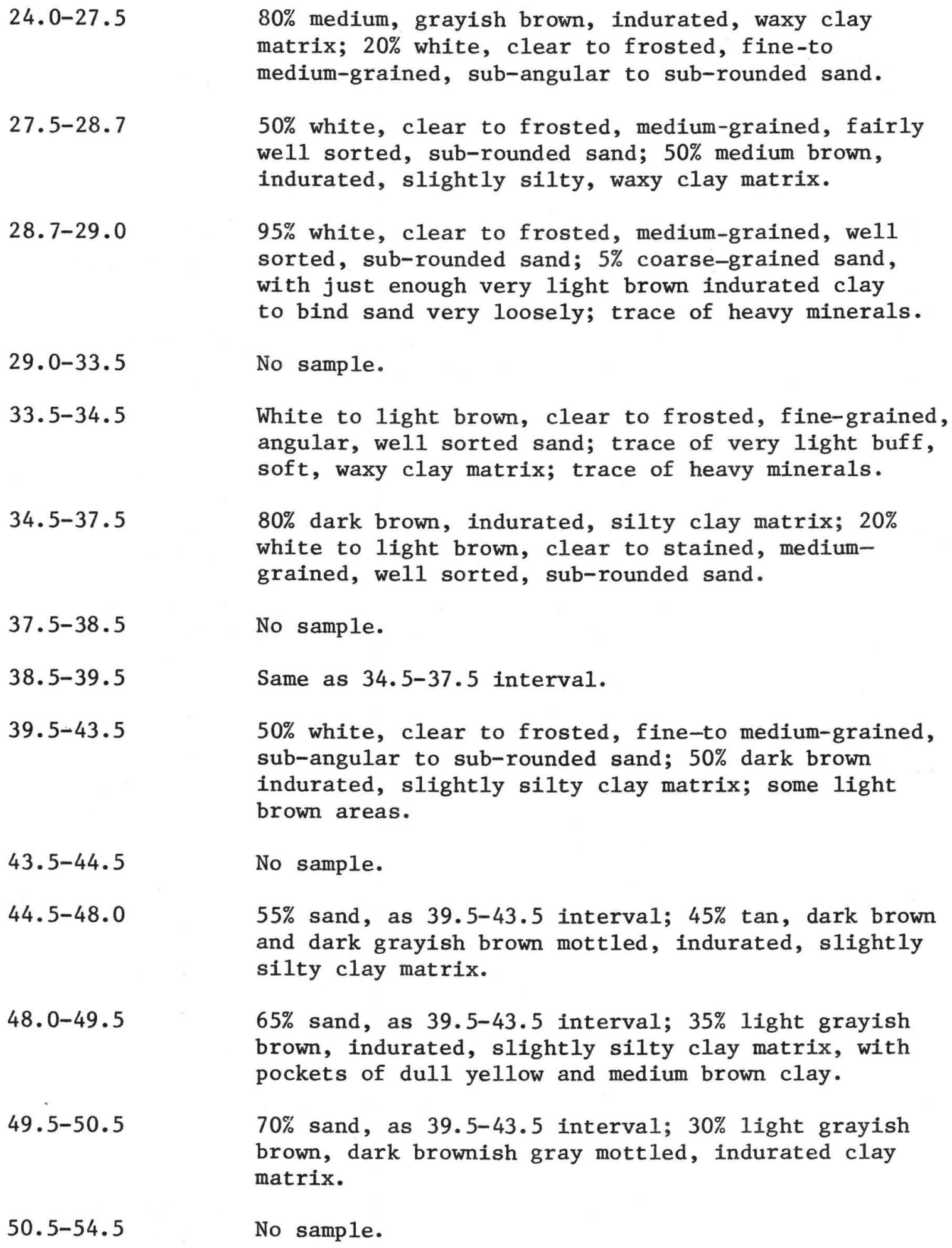

No sample. 
$54.5-57.0$

$57.0-59.5$

$59.5-61.5$

$61.5-66.5$

$66.5-67.5$

$67.5-68.5$

$68.5-76.5$

$76.5-81.0$

$81.0-82.5$

82.5-85.5

$85.5-87.0$

$87.0-95.0$

$95.0-96.0$

$96.0-97.0$

$97.0-100.0$

$100.0-101.0$
$75 \%$ white to tan, clear to stained, medium-grained, fairly well sorted, sub-angular to sub-rounded sand; $25 \% \tan$, indurated clay matrix; trace of heavy minerals.

No sample.

$85 \%$ sand, as $54.5-57.0$ interval; $15 \%$ tan to 1 ight gray, indurated clay matrix.

No sample.

$90 \%$ sand, as $54.5-57.0$ interval; $10 \%$ tan, soft, clay matrix.

$90 \%$ light gray, stained, fine-grained, well sorted, sub-angular sand; 10\% light gray, soft clay matrix.

No sample.

$85 \%$ tan, fine to medium-grained, clear to stained, quartz sand; $15 \%$ light tan, indurated clay matrix.

No sample.

85\% light brown, clear, medium-grained, well sorted, sub-angular sand; $15 \%$ light brown, soft, clay matrix.

$65 \%$ white, frosted, fine-grained, angular, very wel1 sorted, quartz sand; 35\% light tannish gray, soft, clay matrix with medium gray banding in lower 1 foot; trace of heavy minerals.

No sample.

$55 \%$ light gray to tan, stained, fine-grained, angular, very well sorted quartz sand; 45\% light brownish gray, dark gray mottled, soft clay matrix.

Sand, as above; just enough light gray, soft clay to bind sand very loosely.

No sample.

$65 \%$ sand, as $95.0-96.0$ interva1; $25 \%$ tan, soft clay matrix; $10 \%$ medium-to coarse-grained sand; trace of pyrite and heavy minerals. 


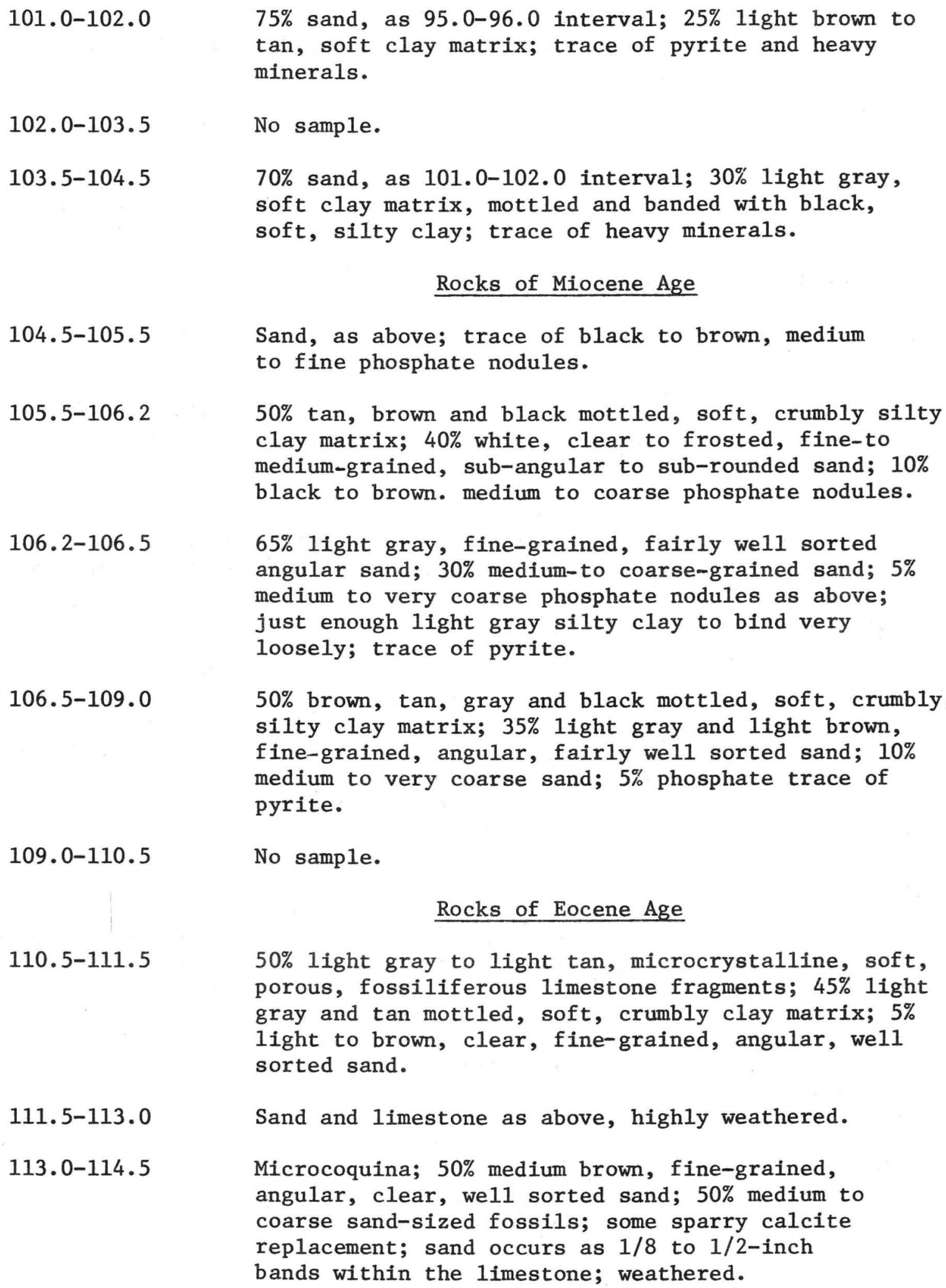

$106.5-109.0$

$109.0-110.5$

No sample.

\section{Rocks of Eocene Age}

$110.5-111.5$

$50 \%$ light gray to light tan, microcrystalline, soft, porous, fossiliferous limestone fragments; $45 \%$ light gray and tan mottled, soft, crumbly clay matrix; $5 \%$ light to brown, clear, fine-grained, angular, well sorted sand.

$111.5-113.0$

Sand and limestone as above, highly weathered.

$113.0-114.5$

Microcoquina; $50 \%$ medium brown, fine-grained, angular, clear, well sorted sand; $50 \%$ medium to coarse sand-sized fossils; some sparry calcite replacement; sand occurs as $1 / 8$ to $1 / 2$-inch bands within the limestone; weathered. 
$114.5-115.5$

Microcoquina; $50 \%$ cream colored, microcrystalline, soft, porous limestone; $50 \%$ large to sma11 fossils; weathered. 


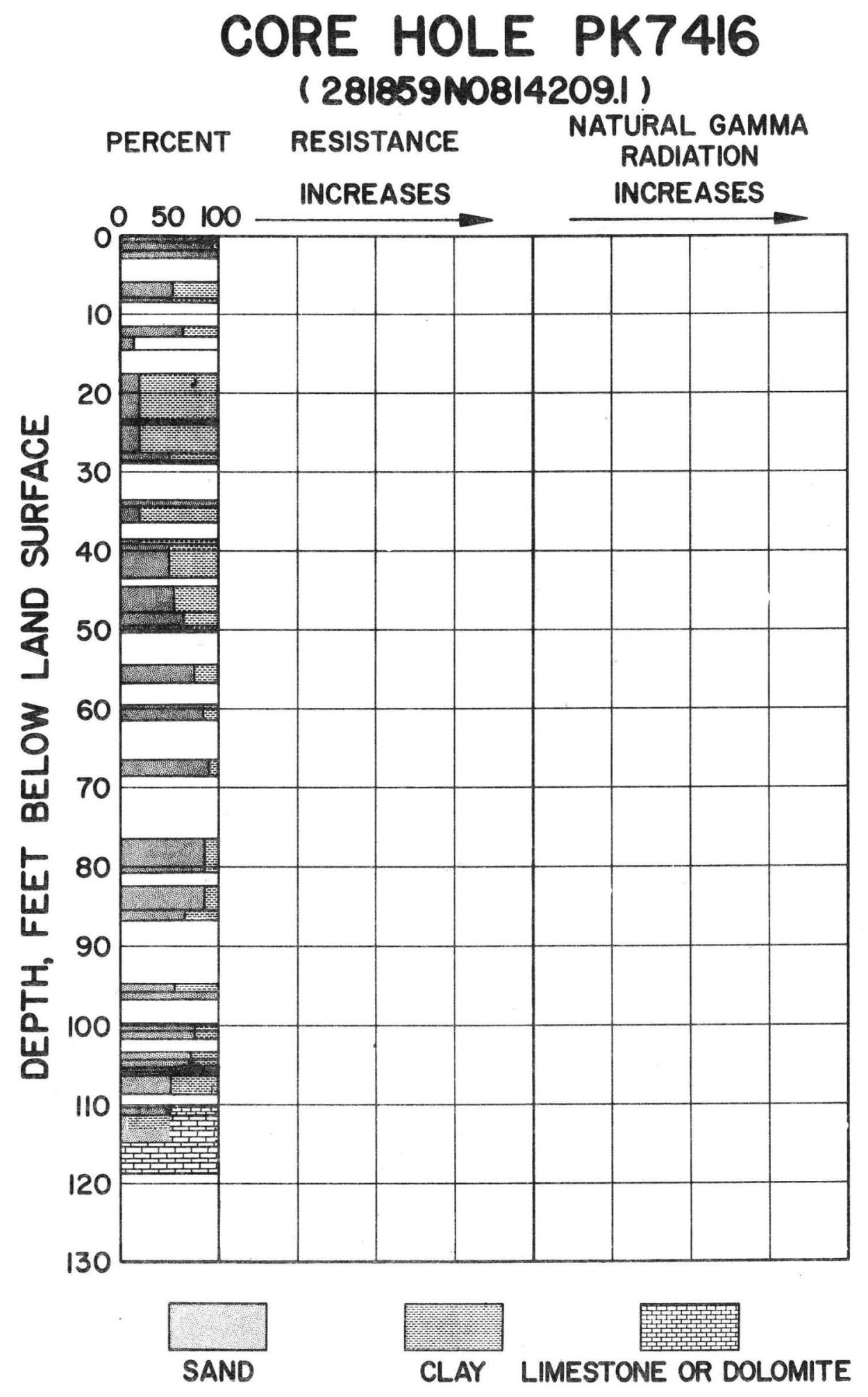


PK7418

Polk County 281206N0815926.0

DEPTH INTERVAL (feet)

$1.0-1.2$

$1.2-2.5$

$2 \cdot 5-4.2$

$4 \cdot 2-5.7$

$5.7-9.5$

$9.5-11.0$

$11.0-13.0$

$13.0-19.2$

$19.2-21.2$

\section{LITHOLOGY}

\section{Post Miocene Rocks}

White, clear to frosted, fine-to medium-grained, angular to sub-rounded quartz sand; trace of heavy minerals.

$75 \%$ white to light brown, clear to stained, fineto medium-grained, angular to sub-rounded sand; $25 \%$ medium brown, soft, crumbly clay matrix.

Tan, stained, fine-to medium-grained, angular to sub-rounded sand; trace of heavy minerals, light brown clay and fine-to medium-grained, indurated, fairly tight, limonitic sandstone.

$50 \%$ white to light yellow, clear to stained, fine, to medium-grained, sub-angular to sub-rounded quartz sand; $50 \%$ white, light green and light brown mottled, waxy clay matrix; trace of heavy minerals.

$50 \%$ 1ight, clear to frosted, fine-to medium-grained, angular to sub-rounded sand; $50 \%$ light brownish gray and light brown mottled, soft, clay matrix; trace of heavy minerals and coarse-grained sand.

No sample.

$98 \%$ very pale green, soft, waxy clay matrix; $2 \%$ white, clear, fine-grained, angular, well sorted sand.

$70 \%$ light green, indurated to soft, waxy clay matrix with minor light brown mottling; $30 \%$ sand, as above.

$85 \%$ sand as $9.5-11.0$ interval; $15 \%$ white, soft clay clay matrix with minor brown and very pale green banding and mottling; trace of heavy minerals.

$65 \%$ white, clear, fine-to medium-grained, angular to sub-rounded quartz sand; $35 \%$ very pale greenish gray indurated clay matrix; very minor light brown mottling; trace of heavy minerals. 
$21.2-22.2$

$22.2-23.5$

$23.5-24.4$

$24.4-25.5$

$25.5-29.0$

$29.0-31.5$

$31.5-40.0$

$40.0-48.2$
$65 \%$ sand, as above; $35 \%$ very light brown, very pale green and white mottled, indurated to soft clay matrix; trace of heavy minerals.

Sand, as 19.2-21.2 interval, with just enough white clay to bind sand very loosely; trace of white phosphate and heavy minerals.

$80 \%$ pale green, soft, waxy clay matrix; $20 \%$ sand, as 19.2-21.2 interval; trace of heavy minerals, phosphate and fragments of white, microcrystalline, hard, porous, silicified limestone with some relic fossil material.

$85 \%$ 1ight bluish green, soft, waxy clay matrix; $15 \%$ white, clear, fine-grained, very well sorted, angular sand.

No sample.

$80 \%$ light bluish green, soft clay matrix; $20 \%$ sand, as 24.4-25.5 interva1; a 1/2-inch wide, very sandy band at 31.1 feet; green and brown mottling in lower 0.2 foot; several fragments of light and dark gray mottled microcrystalline to cryptocrystalline, hard, tight to porous, silicified limestone, with abundant relict fossil material.

\section{Rocks of Oligocene Age}

$80 \%$ cream-colored, microcrystalline, hard, porous limestone; $20 \%$ fossil material with minor replacement by sparry calcite; highly weathered; contains Rotalia mexicana mecatepcensis (Nuttall).

$75 \%$ cream colored, microcrystalline, hard, porous 1imestone; $25 \%$ fossil material; highly weathered. 


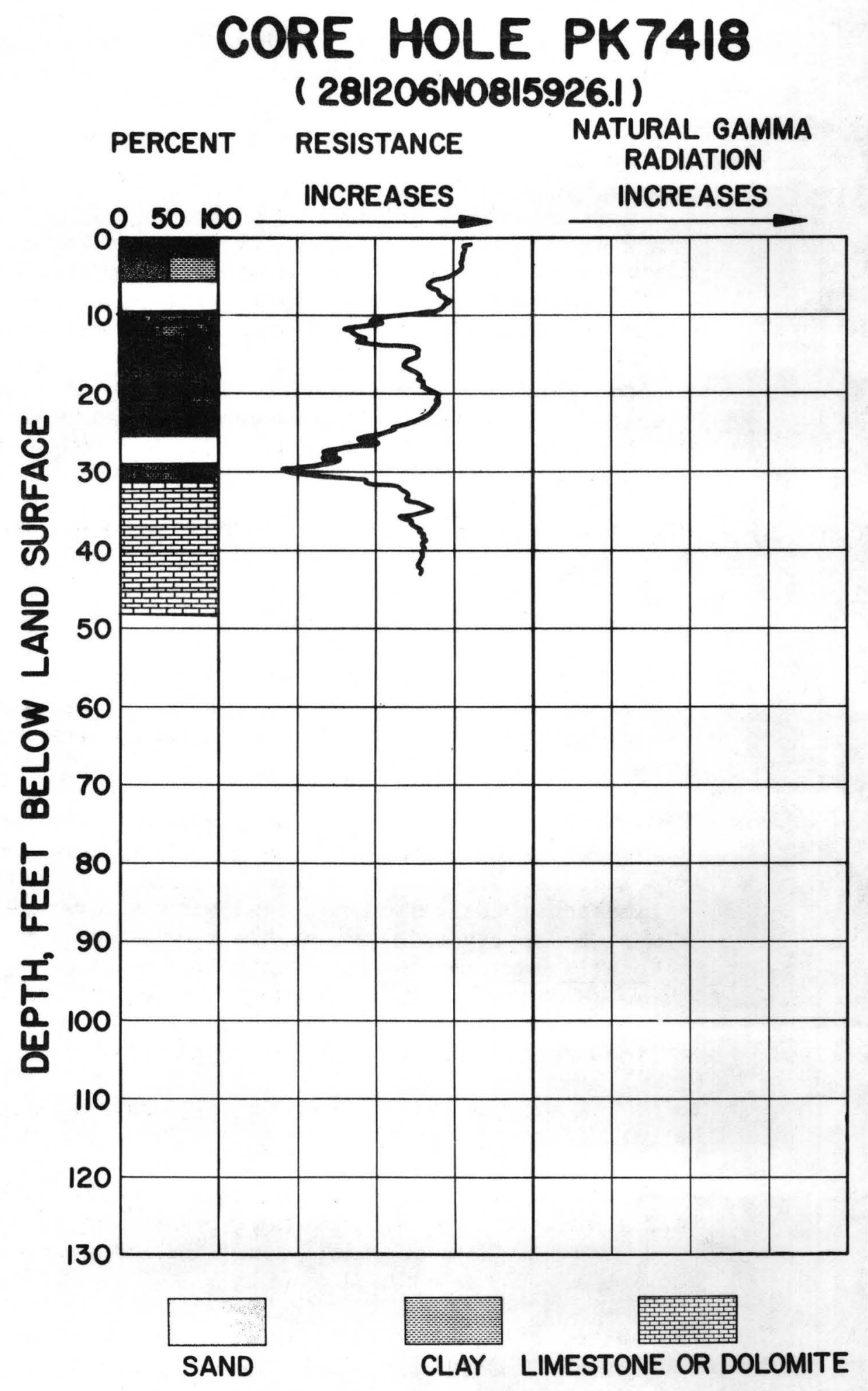


PK7420

Polk County 282031N0814321.1

DEPTH INTERVAL (feet)

$1.5-2.5$

$2.5-3.5$

$3.5-6.0$

$6.0-6.5$

$6.5-7.0$

$7.0-12.0$

$12.0-14.0$

$14.0-23.0$

$23.0-24.5$

$24.5-25.5$

\section{LITHOLOGY}

\section{Post Miocene Rocks}

Light to brown, clear to stained, medium-grained, fairly well sorted, sub-rounded quartz sand; just enough light brownish-gray clay to bind sand very loosely.

$85 \%$ white, frosted, medium-grained, fairly we11 sorted, sub-rounded quartz sand; $15 \%$ dark gray, soft clay matrix.

$90 \%$ light gray sand, as above; $10 \%$ light brown indurated clay matrix.

No sample.

$50 \%$ very light yellow, frosted, medium-grained, fairly well sorted, sub-angular quartz sand; $50 \%$ dull yellow and light gray mottled, soft, sticky clay matrix.

$60 \%$ white, clear to frosted, medium-grained, we11 sorted, sub-angular to sub-rounded quartz sand; $40 \%$ dull yellow, indurated clay matrix with a tan cast.

No sample.

$50 \%$ light gray, clear to frosted, medium-grained, well sorted, sub-rounded quartz sand; 50\% light gray and bluish-gray mottled, soft clay matrix.

$65 \%$ sand, as above; $35 \%$ light gray, indurated clay matrix.

$70 \%$ white to yellow, clear to stained, medium-grained, fairly well sorted, sub-angular quartz sand; $25 \%$

light gray, medium brown and tan mottled, soft clay matrix; $5 \%$ coarse-grained sand.

$75 \%$ white, clear, medium-grained, fairly well sorted, sub-rounded quartz sand; $25 \% 1$ ight to very 1 ight gray, soft clay matrix with very minor medium brown mottling. 
$25.5-26.5$

$26.5-33.0$

$33.0-36.0$

$36.0-47.5$

$47.5-69.5$

$69.5-70.5$

$70.5-75.5$

$75.5-79.5$

$79.5-88.0$

$88.0-94.0$

$94.0-100.0$

$100.0-103.0$

$103.0-125.0$
$80 \%$ white, clear, fine-to medium-grained, fairly well sorted, sub-angular quartz sand; $20 \%$ very light gray, indurated clay matrix; trace of heavy minerals.

$55 \%$ white, clear to frosted, fine-grained, poorly sorted quartz sand; 35\% light gray, indurated clay matrix; $10 \%$ frosted, coarse-to very coarse-grained, well rounded quartz sand.

No sample.

$75 \%$ light brown, medium-to very coarse-grained quartz sand; $25 \%$ light brown, indurated clay matrix.

$80 \%$ brown, medium-grained, quartz sand; $20 \%$ light brown, soft clay matrix; turns to light gray in lower 10 feet of interval.

$80 \%$ white, clear to frosted, fine-grained, fairly well sorted, angular quartz sand; $20 \%$ light brownish gray, soft micaceous clay matrix; trace of heavy minerals.

$70 \%$ sand, as above; $30 \%$ medium gray, soft clay matrix; trace of medium to fine muscovite flakes and heavy minerals.

$80 \%$ white to light gray, clear to frosted, finegrained, very well sorted, angular, silty, quartz sand; $20 \%$ light gray, indurated clay matrix; clay matrix is light greenish gray between 77.0 and 78.4 feet; trace of marcasite.

$60 \%$ sand, as above; $40 \%$ greenish gray soft clay matrix.

No sample.

$60 \%$ white, frosted, medium-to fine-grained, fairly well sorted, sub-angular quartz sand; $40 \%$ greenish gray, soft, silty clay matrix.

\section{Rocks of Eocene Age}

$70 \%$ light gray, very fine-grained, indurated, porous 1imestone; $30 \%$ large foraminifera; scattered sparry calcite replacement; highly weathered; might be called oolitic; contains Dictyoconus sp.

No sample. 


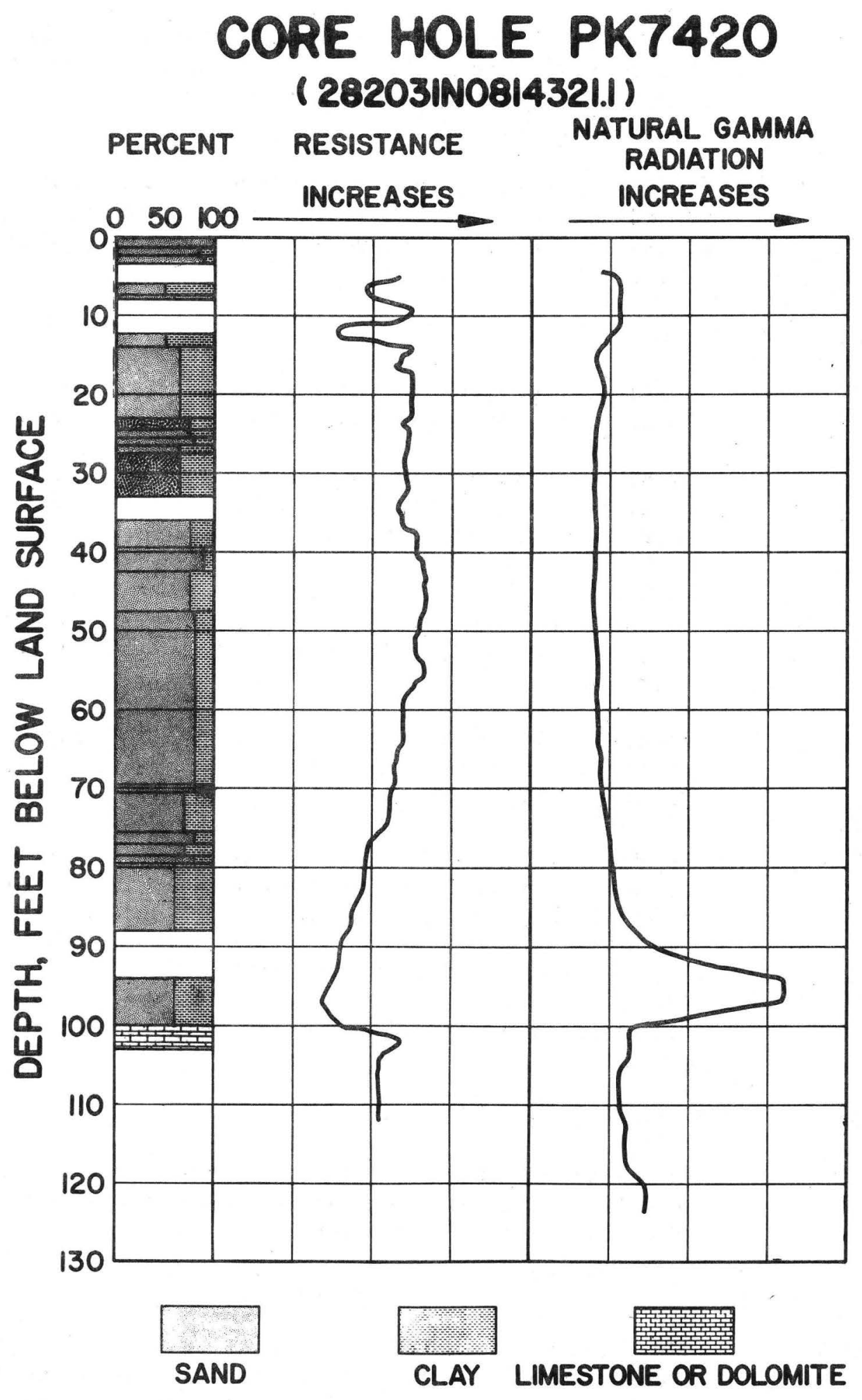


PK7423

Polk County 280923N0815352.1

DEPTH INTERVAL (feet)

$0.0-1.0$

$1.0-2.5$

$2.5-6.0$

$6.0-8.2$

$8.2-11.0$

$11.0-12.0$

$12.0-13.5$

$13 \cdot 5-14.2$

$14 \cdot 2-15 \cdot 5$

\section{LITHOLOGY}

\section{Post Miocene Rocks}

Light gray, clear to frosted, fine-to mediumgrained, angular to sub-rounded quartz sand.

White to light tan, clear to stained, fine-to medium-grained, angular to sub-rounded quartz sand; just enough light brown clay to bind sand very loosely; trace of heavy minerals.

$70 \%$ white, clear, frosted, fine-to medium-grained, angular to rounded quartz sand; $30 \%$ very light gray and tan and dull orange mottled, indurated clay matrix; trace of heavy minerals.

$60 \%$ sand as above; $40 \%$ dull orange, light brown, and white, indurated clay matrix.

$70 \%$ sand, as 2.5-6.0 interval; $30 \%$ very light tan, indurated clay matrix with minor pink and dull orange streaking; trace of heavy minerals.

$80 \%$ white, clear to frosted, fine-grained, very well sorted angular quartz sand; $20 \%$ light tan, indurated clay matrix; trace of heavy minerals.

$80 \%$ white, clear to frosted, fine-to medium-grained, angular to rounded quartz sand; $20 \%$ very light brown, indurated clay matrix with minor mottling by dull orange and light gray, waxy clay; trace of heavy minerals.

$75 \%$ light yellow, clear to stained, fine-to mediumgrained, angular to rounded quartz sand; $25 \%$ light brown and yellow mottled indurated clay matrix; trace of heavy minerals.

98\% light, medium brownish gray mottled and banded, soft, waxy clay matrix; $2 \%$ white, clear, fine-to mediumgrained, angular to rounded quartz sand; trace of heavy minerals. 
$15.5-17.0$

$17 \cdot 0-22 \cdot 0$

$22.0-23.2$

$23.2-24.0$

$24.0-26.0$

$26.0-27.0$

$27.0-27.5$

$27.5-28.0$

$28.0-28.5$

$28.5-28.7$

$28.7-29.0$

$29.0-30.5$
$85 \%$ white, clear to frosted, fine-grained, angular, fairly well sorted quartz sand; $10 \%$ white, light brown banded, soft clay matrix; $5 \%$ medium grained sand; trace of heavy minerals.

$60 \%$ white, clear to frosted, medium-grained, fairly we11 sorted, sub-rounded quartz sand; $40 \%$ very pale greenish gray, indurated clay matrix.

$95 \% 1$ ight green, soft, waxy clay matrix; $5 \%$ light gray, clear, medium-grained, fairly well sorted, sub-rounded quartz sand.

\section{Rocks of Miocene Age}

$75 \%$ white, clear to frosted, medium-grained, well sorted, sub-rounded to rounded quartz sand; $25 \%$ very pale green, soft clay matrix; trace of heavy minerals.

$90 \%$ sand, as above; $10 \%$ clay, as above.

$60 \%$ cream colored, soft clay matrix; trace of heavy minerals; $40 \%$ sand, as $23.2-24.0$ interval.

$70 \%$ sand, as $23.2-24.0$ interval; $30 \%$ light gray, soft clay matrix.

$85 \%$ cream colored, soft clay matrix; $15 \%$ sand, as 23.2-24.0 interva1; trace of black, fine-to mediumphosphate nodules.

$75 \%$ very pale green, soft clay matrix; $25 \%$ sand, as 23.2-24.0 interval; trace of phosphate and heavy minerals.

$80 \%$ cream colored, soft clay matrix; $20 \%$ sand, as 23.2-24.0 interval; trace of phosphate and heavy minerals.

$40 \%$ off-white, soft, poorly consolidated, powdery, crumbly clay matrix; $30 \%$ sand, as $23.2-24.0$ interval; $30 \%$ fine-grained sand; trace of black to tan, fineto medium-grained phosphate.

$55 \%$ sand, as $23.2-24.0$ interva1; $30 \%$ cream colored, soft clay matrix; $15 \%$ black to light tan, fine to very coarse phosphate nodules. 
$30.5-30.7$

$30.7-31.5$

$31.5-37.5$

$37.5-38.5$

$38.5-39.0$

$39.0-40.0$

$40.0-42.5$

$42 \cdot 5-42.7$

$42.7-44.2$

$44.2-45.7$

$45.7-52.0$
$55 \%$ sand, as $23.2-24.0$ interva1; $45 \%$ very pale green, soft clay matrix; $10 \%$ phosphate as 29.0-30.5 interval.

$60 \%$ white, clear, fine-grained, fairly we11 sorted, angular sand; $35 \%$ off-white, very pale green mottled, soft clay matrix; $5 \%$ black and tan, fine to medium phosphate nodules.

$50 \%$ cream colored and pale green clay matrix; $30 \%$ white, clear to frosted, fine-to medium-grained, angular to rounded quartz sand; $20 \%$ multicolored, fine to very coarse phosphate nodules.

$50 \%$ cream colored, indurated, crumbly clay matrix; $30 \%$ sand, as $31.5-37.5$ interval; $20 \%$ phosphate as 31.5-37.5 interval.

$50 \%$ pale green, soft clay matrix with $1 / 2-$ inch band of pure pale green clay; $30 \%$ sand, as $31.5-37.5$ interval; $20 \%$ phosphate as $31.5-37.5$ interval.

$60 \%$ cream colored, soft crumbly clay matrix with minor du11 yellow mottling; $30 \%$ sand, as $31.5-37.5$ interval; $10 \%$ multicolored medium phosphate nodules.

$90 \%$ buff, soft, waxy clay matrix with dull yellow mottling; $10 \%$ white, clear to frosted, fine-to mediumgrained, angular to sub-rounded quartz sand; trace of multicolored phosphate nodules.

$50 \%$ white and light brown mottled, indurated clay matrix; $40 \%$ sand, as above; $10 \%$ multicolored, fine-to coarse-grained phosphate.

$99 \%$ buff, soft, crumbly clay matrix with dull yellow mottling; $1 \%$ sand, as 40.0-42.5 interval; trace of multicolored, fine-to medium-grained phosphate nodules.

$60 \%$ dull yellow, buff, off-white, and grayish brown mottled, soft, crumbly clay matrix; $30 \%$ white, clear, fine-to medium-grained, angular to sub-angular quartz sand; $10 \%$ tan and orange, fine-to medium-grained phosphate nodules.

No sample. 
$52.0-54.0$

$54.0-55.2$

$55.2-56.2$

$56.2-60.5$

$60.5-65.0$

$65 \cdot 0-68.0$

$68.0-72.2$
$60 \%$ pale green and tan mottled, soft clay matrix; $30 \%$ light gray, frosted, medium-grained, very we11 sorted, sub-angular sand; $10 \%$ multicolored, fine to very coarse phosphate nodules.

$60 \%$ buff and pale green mottled, soft clay matrix; $30 \%$ sand, as above; $10 \%$ phosphate as $52.0-54.0$ interval.

$80 \%$ pale green and dark brown mottled, soft clay matrix; $15 \%$ white, clear, fine-to medium-grained, angular to sub-angular quartz sand; $5 \%$ pisolitic silica.

\section{Rocks of Oligocene Age}

$60 \%$ calcareous clay matrix; $20 \%$ cream colored, microcrystalline, hard, porous limestone; $20 \%$ large to small fossils.

$60 \%$ clay as above; $35 \%$ limestone as above; $5 \%$ fossils as above.

$60 \%$ cream colored, light gray mottled, indurated, calcareous clay matrix.

No sample. 


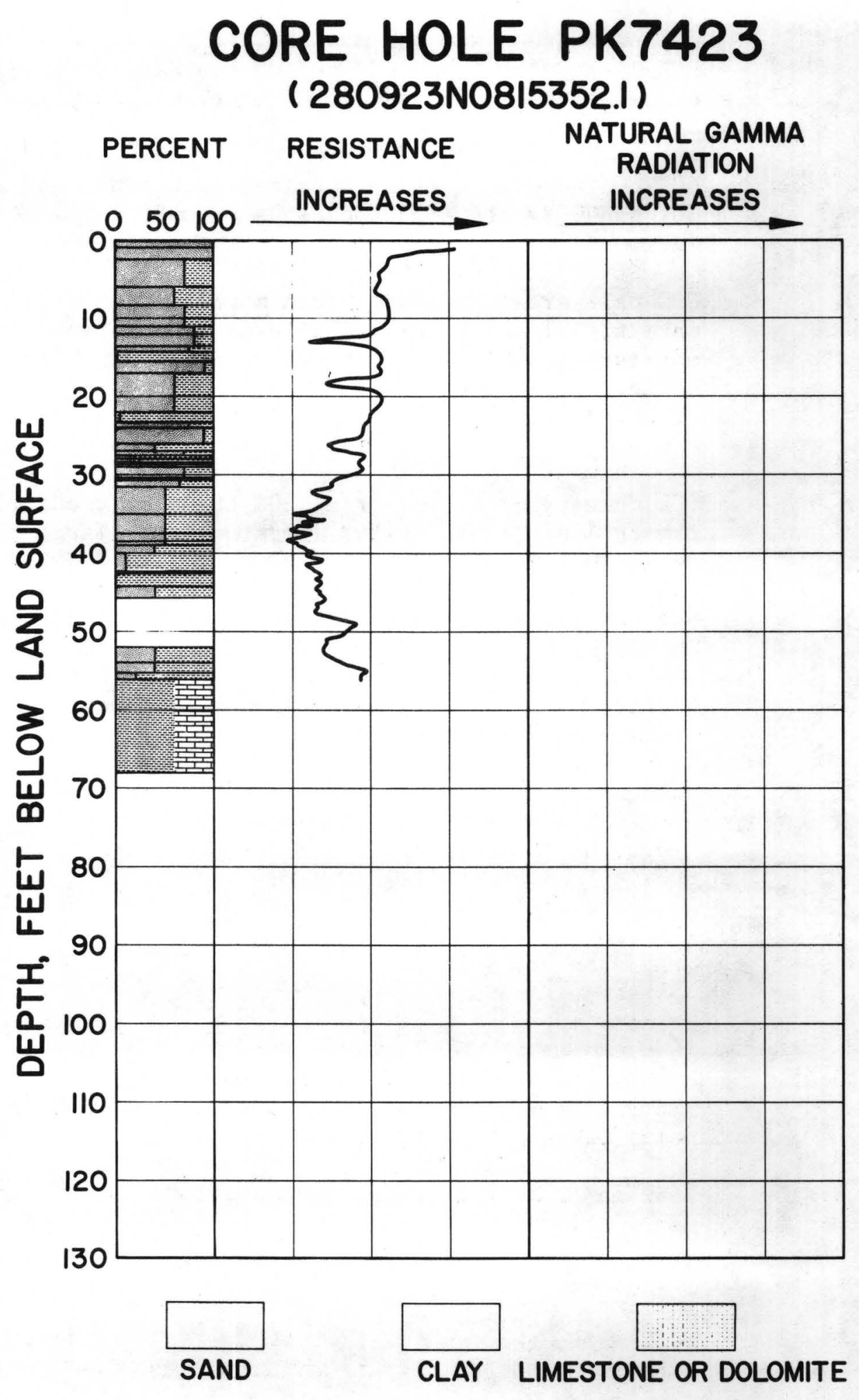


PK7424

Polk County 281412N0814524.1

DEPTH INTERVAL (feet)

$0.0-2.0$

$6.5-8.0$

$8 \cdot 0-13.5$

$13 \cdot 5-23.0$

$23.0-29.0$

$29.0-37.0$

$37.0-40.0$

$40.0-48.0$

$48.0-56.0$

\section{LITHOLOGY}

\section{Post Miocene Rocks}

White to light gray, clear to frosted, mediumgrained, fairly well sorted, sub-rounded quartz sand; trace of heavy minerals and 1ight gray to light brown clay.

No sample.

$50 \%$ white, clear to frosted, medium-grained, fairly well sorted, sub-angular to sub-rounded quartz sand; $50 \%$ light tan, dull yellow and bright orange mottled, indurated clay; scattered yellow and red quartz grains.

$50 \%$ sand, as above; $50 \%$ light gray, soft, sticky, clay matrix with irregular 1/4-inch bands of dull yellow and bright orange.

$60 \%$ white, clear to frosted, medium-grained, fairly we11 sorted, sub-rounded quartz sand; $40 \% 1$ ight and medium brown banded, soft clay matrix; trace of heavy minerals.

75\% white, clear to frosted, medium-grained, fairly we11 sorted, sub-angular to sub-rounded quartz sand; $25 \%$ tan, indurated clay matrix; trace of heavy minerals.

$60 \%$ white, clear to frosted, fine-grained, very we11 sorted, angular, silty quartz sand; $40 \%$ tan, soft clay matrix; trace of heavy minerals.

$65 \%$ sand, as above; $35 \%$ very light tan to off-white, soft clay matrix; trace of heavy minerals.

No sample.

$45 \%$ sand as $23.0-29.0$ interval; $45 \%$ light tan to offwhite, soft clay matrix; $10 \%$ medium-grained sand.

$70 \%$ white, clear to frosted, fine-to medium-grained, fairly well sorted, angular to rounded, quartz sand; $30 \%$ tan, soft clay matrix; trace of heavy minerals. 
$56.0-60.0$

$60.0-65.0$

$65 \cdot 0-67.0$

$67.0-71.0$

$71.0-82.0$

$82.0-88.0$

$88.0-104.0$
No sample.

$50 \%$ coarse-to very coarse-grained, clear, we11 rounded quartz sand; $30 \%$ sand, as $48.0-56.0$ interval; $20 \%$ light tan to light brown, silty, soft clay matrix.

$55 \%$ white, clear to frosted, fine-grained, fairly we11 sorted, angular quartz sand; $45 \%$ tan, soft, silty clay matrix; trace of heavy minerals.

$50 \%$ light gray, stained, fine-grained, we11 sorted, angular, silty quartz sand; $50 \%$ dark greenish gray, soft clay matrix.

$50 \%$ sand, as above; $50 \%$ dark greenish gray, soft, indurated clay matrix with dark gray mottling.

\section{Rocks of Eocene Age}

$75 \%$ light gray, indurated, powdery, calcareous clay matrix; $25 \%$ very large to large foraminifera; contains Sphaerogypsina globula (Reuss), Lepidocyclina ocalana floridana (Cushman), Echinocythereis okeechobiensis (Swain), and Reusse1la sculptilis (Cushman).

No sample. 


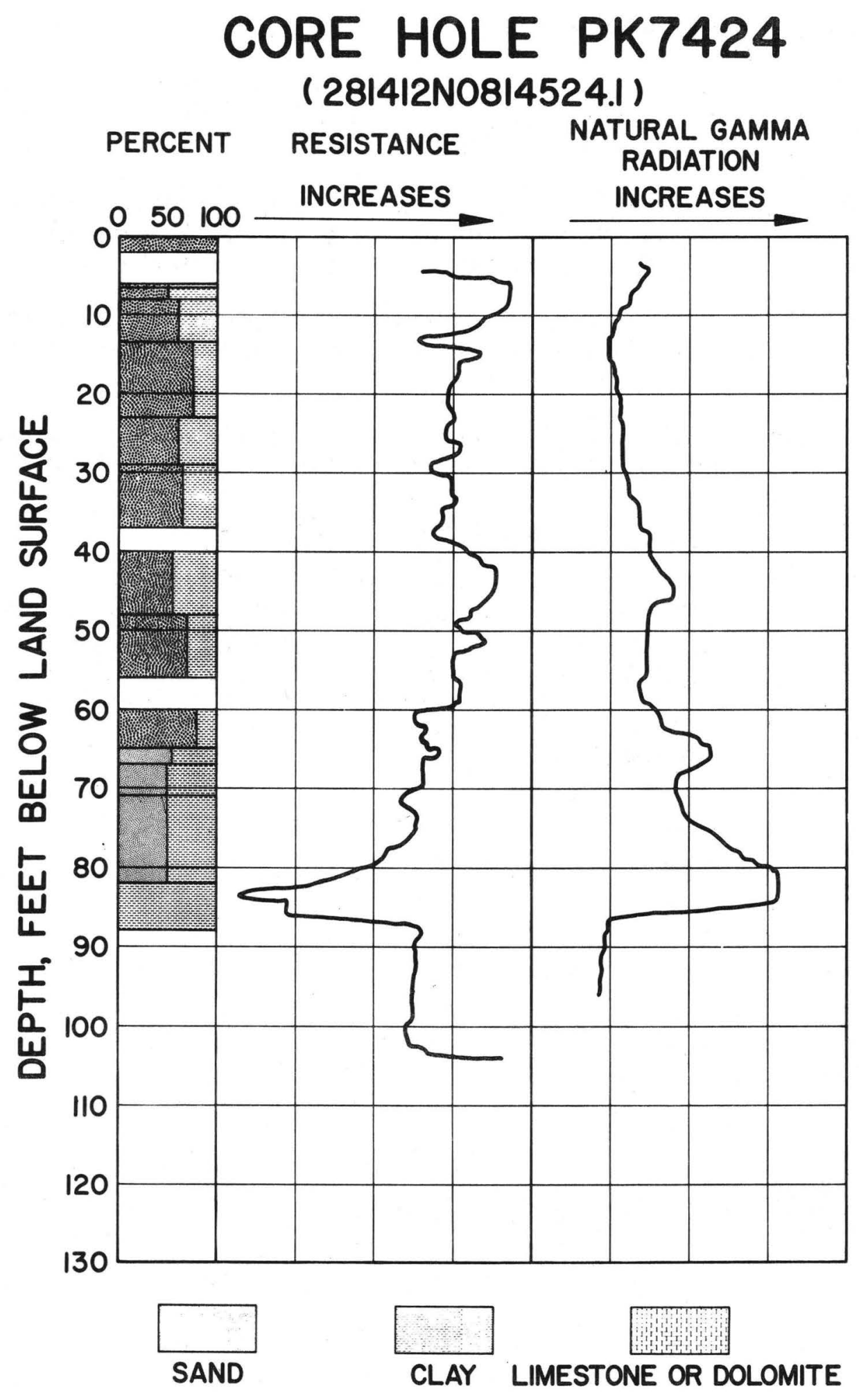


PK7425

Polk County 281239N0814715.1

DEPTH INTERVAL (feet)

$0.0-4.0$

$4.0-10.0$

$10.0-13.5$

$13 \cdot 5-16.0$

$16.0-22.0$

$22.0-40.0$

$40.0-41.0$

$41.0-42.7$

$42.7-43.2$

\section{LITHOLOGY}

\section{Post Miocene Rocks}

95\% 1ight gray with brown tint, stained, mediumgrained, fairly we11 sorted, rounded quartz sand; $5 \%$ coarse-to very coarse-grained sand; trace of medium brownish gray clay.

$55 \%$ white, frosted, medium-grained, fairly we11 sorted, rounded sand; $40 \%$ off-white, soft clay matrix; 5\% coarse-to very coarse-grained sand.

$70 \%$ light gray, frosted, fine-to very coarse-grained, angular to well rounded quartz sand; $30 \%$ tan, soft clay matrix; trace of heavy minerals.

$65 \%$ white, clear to frosted, fine-grained, fairly we11 sorted, angular quartz sand; $35 \% 1$ ight tan, soft clay matrix; trace of heavy minerals.

No sample.

$65 \%$ white, clear to frosted, fine-grained, fairly wel1 sorted, angular quartz sand; $30 \%$ tan, soft clay matrix; $5 \%$ medium-grained sand; trace of heavy minerals.

\section{Rocks of Miocene Age}

$60 \%$ light gray, clear, medium-grained, fairly we11 sorted, sub-angular to sub-rounded quartz sand; $25 \%$ very pale green, soft clay matrix; 15\% light tan, fine to coarse phosphate.

$99 \%$ bluish green and medium green mottled, soft, waxy clay matrix; $1 \%$ white, clear, fine-grained, very we11 sorted, angular quartz sand; trace of light brown, fine to medium phosphate.

95\% light gray, clear, medium-grained, well sorted, rounded quartz sand; $5 \%$ multicolored, fine to very coarse phosphate nodules; a 1/2-inch band of clay at 42.8 feet. 
$43.2-43.5$

$43.5-43.7$

$43.7-46.0$

$46.0-47.2$

$47.2-52.0$

$52.0-53.2$

$53.2-54.0$

$54.0-54.5$

$54.5-55.0$

$55.0-57.0$

$57.0-58.0$

$58.0-61.0$
$60 \%$ sand, as above; $40 \%$ very light green, soft clay matrix mottled with medium greenish gray, waxy clay; trace of phosphate.

$70 \%$ medium greenish gray, soft crumbly, waxy clay matrix; $20 \%$ sand, as 42.7-43.2 interva1, $10 \%$ phosphate as 43.2-43.5 interval.

$55 \%$ medium green, soft, waxy clay matrix; $45 \%$ white, clear, medium grained, well sorted sub-rounded quartz sand; trace of phosphate.

$50 \%$ sand, as above; $50 \%$ 1ight green, soft clay matrix; trace of phosphate.

No sample.

$50 \%$ buff, soft to indurated clay matrix; $40 \%$ white, clear, medium-grained, fairly well sorted, subrounded sand; $5 \%$ fine grained quartz sand; $5 \%$ black, fine to very coarse phosphate nodules.

$60 \%$ white, clear, fine to medium-grained, angular to sub-rounded sand; 30\% light green, soft clay matrix, mottled with medium brown and deep red clay; $10 \%$ multicolored, fine to very coarse phosphate nodules.

$75 \%$ sand, as above; $15 \%$ very light green, soft clay matrix; $10 \%$ phosphate as above.

$60 \%$ brownish green and medium green mottled and banded, soft clay matrix; $35 \%$ white, clear, fine-to medium-grained, angular to sub-rounded quartz sand; $5 \%$ multicolored, fine to very coarse phosphate; trace of heavy minerals.

$50 \%$ cream colored, indurated, we11 consolidated, calcareous siltstone with minor light gray mottling; $45 \%$ sand, as above; $5 \%$ multicolored fine to medium phosphate; a few cylindrical tubes, approximately 1/2-inch in diameter, are filled with olive green, soft, waxy clay; trace of heavy minerals.

$60 \%$ light tan to light gray, soft, calcareous siltstone; $40 \%$ sand, as 54.5-55.0 interval; trace of phosphate and heavy minerals.

85\% 1ight gray, indurated, calcareous, siltstone matrix; $15 \%$ sand, as 54.5-55.0 interva1; trace of phosphate and heavy minerals. 
$61.0-63.0$

$63.0-65.0$

$65 \cdot 0-87.0$

$87.0-88.0$

$88.0-91.0$

$91.0-101.0$

$101.0-105.9$
90\% medium gray, hard, very well consolidated, calcareous siltstone; $10 \%$ fine-to medium-grained. quartz sand; trace of multicolored, fine to medium phosphate nodules.

No sample.

\section{Rocks of Eocene Age}

No sample. Top of interval based on geophysical logs.

$70 \%$ white, clear to frosted, fine-grained, we11 sorted, angular quartz sand; $30 \%$ white, soft clay matrix; trace of muscovite and heavy minerals.

$85 \%$ sand, as above; $15 \%$ tan, indurated clay matrix; trace of muscovite and heavy minerals.

No sample.

$75 \%$ cream colored, soft, calcareous clay matrix; $25 \%$ cream colored, microcrystalline, soft, porous limestone with large and small fossils; highly weathered; contains Lepidocyclina ocalana floridana (Cushman), and Cibicides mississippiensis ocalanus (Cushman). 


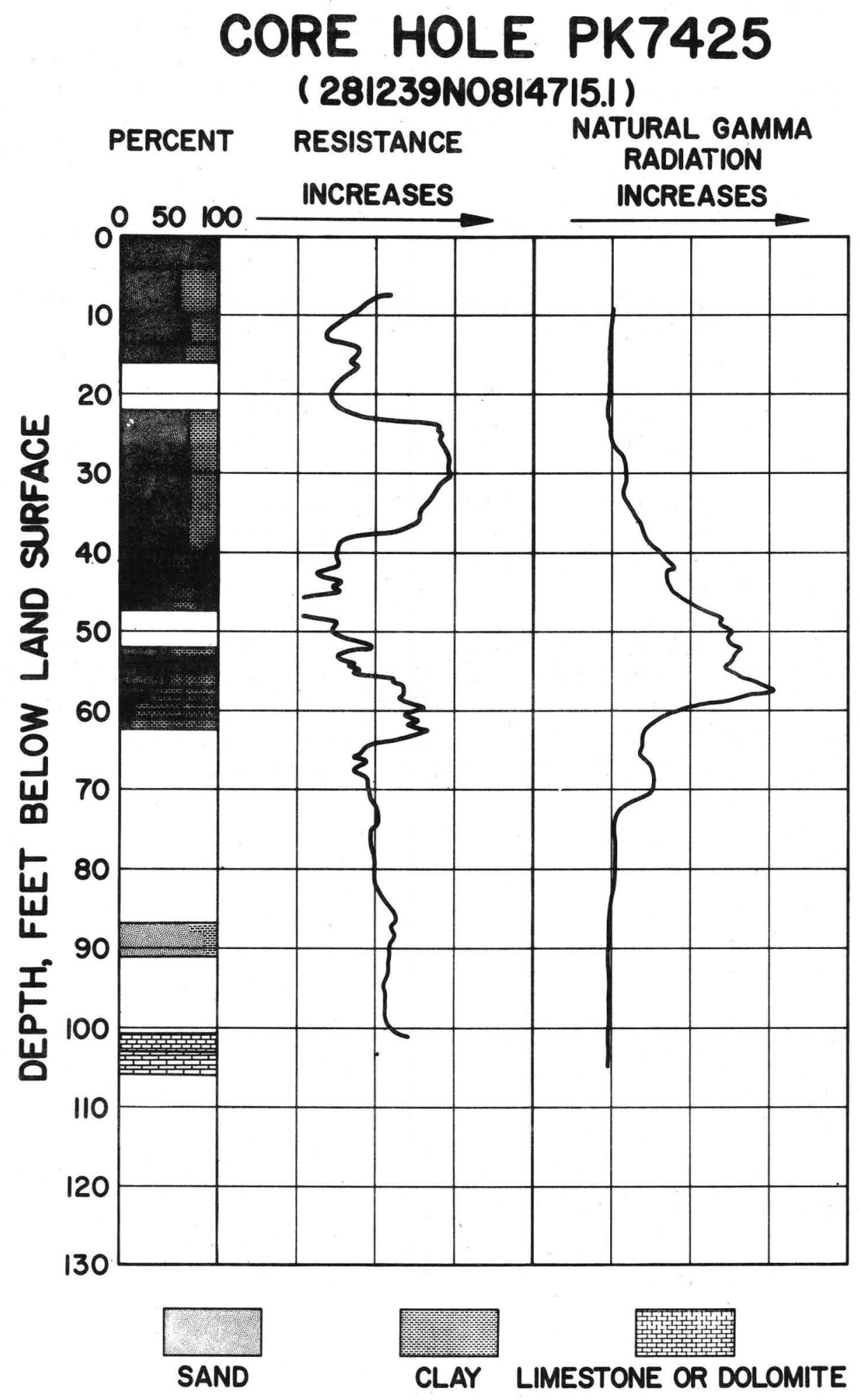


Polk County 281040N0814752.1

DEPTH INTERVAL (feet)

$0.0-1.0$

$1.0-3.0$

$3.0-10.0$

$10.0-11.0$

$11.0-13.5$

$13.5-17.5$

$17.5-20.5$

$20.5-=28.5$

$28.5-31.5$

$31.5-35.5$

$35.5-40.5$

$40.5-44.5$

$44.5-51.5$

\section{LITHOLOGY}

\section{Post Miocene Rocks}

Light brown, stained, medium-grained, fairly well sorted, sub-rounded quartz sand.

Tan, stained, medium-grained, fairly well sorted, sub-rounded sand.

No sample.

$75 \%$ 1ight brown, stained, medium-grained, fairly we11 sorted, sub-rounded quartz sand; $20 \%$ medium brown, soft, crumbly clay matrix; $5 \%$ coarse-grained sand.

$60 \%$ tan, light gray mottled, indurated clay matrix; $30 \%$ white to tan, clear to stained, medium-grained, fairly we11 sorted, sub-rounded quartz sand; $5 \%$ coarse-grained sand; $5 \%$ fine-grained sand.

No sample.

$60 \%$ light gray, indurated clay matrix with slight light brow; $40 \%$ white, frosted, medium-to coarsegrained, sub-rounded to rounded sand.

No sample.

$75 \%$ sand, as $17.5-20.5$ interva1; $25 \%$ tan, indurated clay matrix.

No sample.

$60 \%$ white, clear, fine-grained, angular, well sorted, quartz sand; $35 \%$ light brown, indurated to soft clay matrix; $5 \%$ medium-to coarse-grained sand; trace of fine to medium muscovite flakes and heavy minerals.

$70 \%$ sand, as above; $30 \%$ cream colored, indurated clay matrix; trace of muscovite and heavy minerals.

$60 \%$ sand, as $35.5-40.5$ interval; $40 \%$ tan, soft clay matrix; trace of heavy minerals and muscovite. 
$51.5-52.5$

$52.5-54.5$

$54.5-56.5$

$56.5-58.7$

$58.7-60.5$

$60.5-62.5$

$62.5-62.7$

$62.7-81.5$

$81.5-84.7$

$84.7-88.0$
$75 \%$ sand, as $35.5-40.5$ interval; $25 \%$ white to light brown, mottled, indurated clay matrix; trace of muscovite and heavy minerals.

\section{$\underline{\text { Rocks of Miocene Age }}$}

$70 \%$ white, clear to frosted, fine-to medium-grained, angular to rounded quartz sand; $25 \%$ very pale green, soft clay matrix; $5 \%$ brown to white, fine to very coarse phosphate nodules; a few small quartz pebbles.

$35 \%$ sand, as above; $25 \%$ black, small phosphate pebbles; $20 \%$ very pale green and off-white mottled, soft, crumbly clay matrix; $20 \%$ black, fine to coarse phosphate nodules; trace of pisolitic silica.

Light green, bluish green and light brown mottled, indurated clay matrix; trace of fine-grained sand and phosphate.

No sample.

99\% medium green, soft, waxy, platey clay matrix; $1 \%$ white, clear, fine-to medium-grained, angular to sub-rounded quartz sand; trace of fine to very coarse phosphate.

Off-white, mottled, soft, porous, very fine crystalline, argillaceous dolomite; trace of fine-to medium-grained quartz sand.

No sample.

$80 \%$ light green and gray, soft, very fine crystalline, porous, argillaceous dolomite matrix; $20 \%$ white, clear, fine to medium-grained, angular to sub-rounded quartz sand; trace of medium to fine phosphate fragments.

$85 \%$ 1ight gray, clear to frosted, fine-grained, well sorted, angular quartz sand; 15\% light green and very light gray mottled, soft, crumbly clay matrix with a few pockets of medium green, soft waxy clay; trace of heavy minerals. 
Rocks of Oligocene Age

$88.0-98.0$

40\% small fossils and large shell fragments; $30 \%$ white, clear to frosted, fine-to medium-grained, angular to sub-rounded quartz sand; $30 \%$ off-white, microcrystalline, hard, porous limestone; scattered replacement by sparry calcite.

$98.0-123.4$

No sample. 


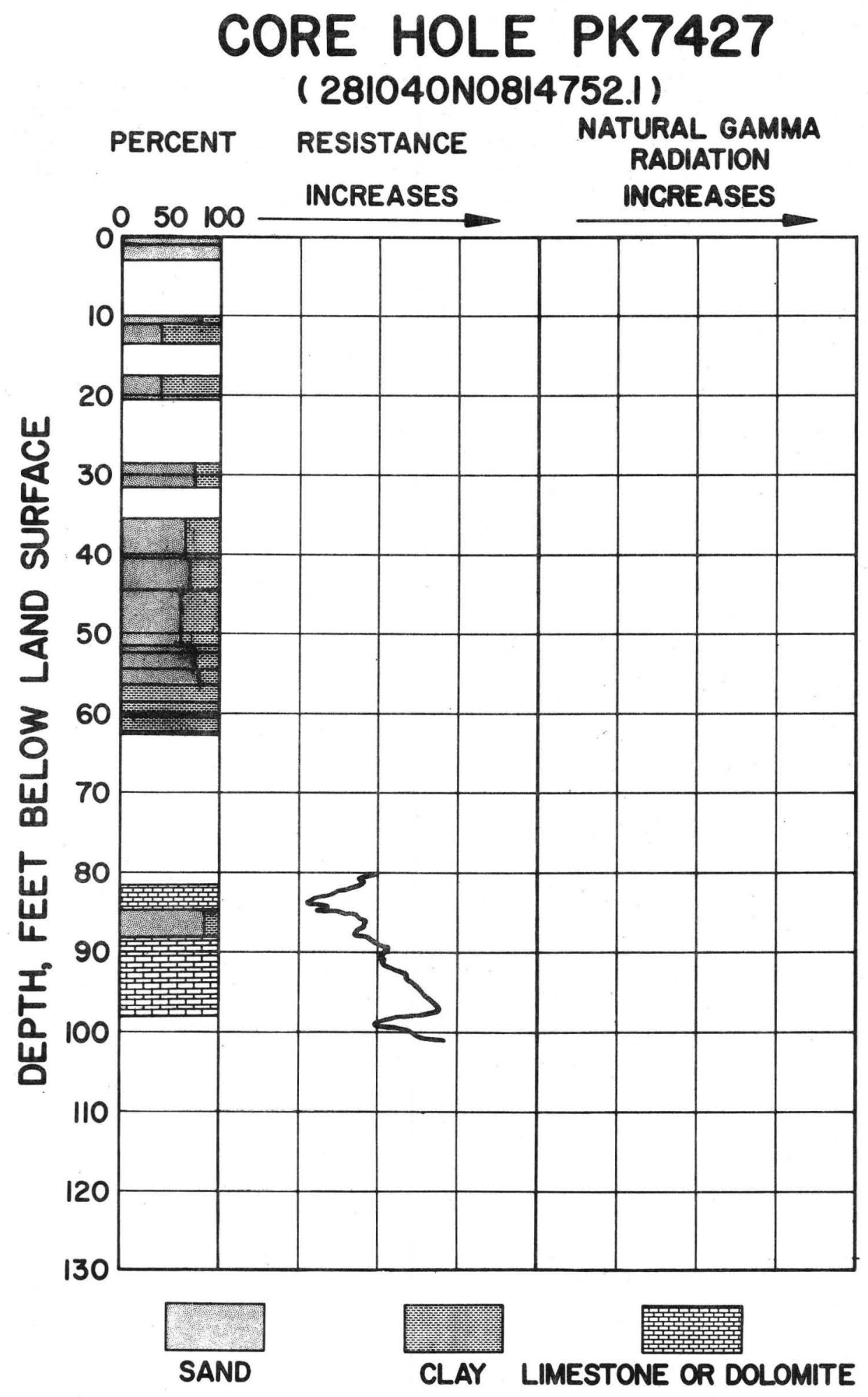


PK7.429

Po1k County 280723N0814850.1

DEPTH INTERVAL (feet)

$0.0-1.0$

$1.0-5.0$

$5.0-7.5$

$7.5-10.0$

$10.0-11.0$

$11.0-13.5$

$13.5-16.0$

$16.0-24.0$

$24.0-53.0$

$53.0-61.5$

\section{LITHOLOGY}

\section{Post Miocene Rocks}

Light brown to light gray, stained, medium-grained, fairly well sorted, sub-rounded quartz sand; trace of light gray clay.

Tan, stained, medium-grained, fairly well sorted, sub-rounded sand; trace of tan clay and lignite.

No sample.

$50 \%$ light tan, indurated clay matrix, with minor white mottling; $40 \%$ white to yellow, clear to stained, mediumgrained, fairly we11 sorted, sub-angular to sub-rounded quartz sand; $10 \%$ fine-grained sand.

$98 \%$ white, dark brown, and light gray mottled, hard waxy clay; $2 \%$ white and clear, fine-to medium-grained, angular to sub-angular sand.

$90 \%$ white, clear to frosted, medium-grained, rounded, fairly we11 sorted quartz sand; $10 \%$ fine-grained quartz sand; just enough tan clay to bind sand loosely; trace of heavy minerals.

$85 \%$ white, clear to frosted, fine-to medium-grained, angular to sub-rounded quartz sand; $15 \%$ white to offwhite, indurated clay matrix; trace of heavy minerals.

No sample.

$90 \%$ sand, as $13.5-16.0$ interval; $10 \%$ white, indurated crumbly clay matrix; trace of heavy minerals.

\section{Rocks of Miocene Age}

$95 \%$ sand, as $13.5-16.0$ interval; $5 \%$ light tan, soft, poorly consolidated clay matrix; two 1-inch bands of medium gray, soft pure clay containing phosphate nodules occur in this interval; trace of heavy minerals. 
$61.5-62.5$

$62.5-63.5$

$63.5-64.0$

$64.0-65.5$

$65.5-69.5$

$69.5-72.5$

$72.5-73.2$

$73.2-73.5$

$73.5-76.0$

$76.0-77.0$

$77.0-80.0$
$60 \%$ light brownish gray, soft clay matrix; $20 \%$ light gray, frosted, medium-grained, well sorted, rounded to sub-rounded quartz sand; $20 \%$ black, fine to very coarse phosphate nodules.

$80 \%$ medium brown and medium gray mottled, soft waxy clay matrix; $20 \%$ sand, as above; trace of phosphate as above.

$75 \%$ clay as above; $20 \%$ light gray, clear to frosted, fine to medium-grained, angular to sub-rounded quartz sand; $5 \%$ brown and black, fine to very coarse phosphate nodules.

Very light gray, soft, slightly calcareous clay matrix; trace of phosphate, sand, as above.

$50 \%$ light gray, with slight brown tint, soft clay matrix; $40 \%$ sand, as $63.5-64.0$ interval; $10 \%$ black to brown, fine to medium phosphate nodules; brown, soft, waxy, blocky clay mottling in upper 2 feet of this interval.

$80 \%$ very light gray, soft, slightly calcareous silt matrix; $10 \%$ white, clear, medium grained, fairly well sorted, sub-rounded quartz sand; $10 \%$ dark to medium brown, medium to very coarse, phosphate nodules.

Light gray, soft, slightly calcareous clay matrix; trace of phosphate nodules, white, clear, medium-to fine-grained, fairly well sorted, sub-rounded quartz sand.

$70 \%$ brownish gray, soft clay matrix; $20 \%$ white, clear to frosted, medium-grained, fairly well sorted, subrounded quartz sand; $10 \%$ black and brown, fine to very coarse phosphate.

$75 \%$ medium gray, soft, waxy clay matrix; $20 \%$ white, clear to frosted, very fine-to fine-grained, angular, well sorted quartz sand; $5 \%$ very fine to medium phosphate nodules.

$95 \%$ very light gray, soft, silt matrix; $5 \%$ sand, as above; trace of phosphate.

No sample. 
$80.0-82.0$

$82.0-83.0$

$83.0-92.5$

$92.5-94.7$

$94.7-100.0$

$100.0-102.0$

$102.0-103.5$

$103.5-105.5$

$105.5-111.5$

$111.5-112.5$

$112.5-113.5$
95\% cream colored, soft, slightly calcareous silt matrix; $5 \%$ sand, as 73.5-76.0 interval; trace of phosphate and small fragments of light gray microcrystalline, hard dolomite.

$50 \%$ very light gray, indurated clay matrix; $35 \%$ light gray, clear to frosted, medium-grained, fairly well sorted, sub-rounded quartz sand; $15 \%$ black to brown, fine to very coarse phosphate nodules; trace of heavy minerals.

$70 \%$ off-white, microcrystalline, hard, porous dolomite matrix; $25 \%$ white, clear, fine-to medium-grained, angular to sub-rounded quartz sand; $5 \%$ black to brown, fine to very coarse phosphate nodules.

$50 \%$ sand, as above; $50 \%$ tan, soft, silty clay matrix; trace of phosphate.

$80 \%$ medium gray, soft, waxy clay matrix; $15 \%$ white, clear to frosted, fine-to very fine-grained, angular, well sorted quartz sand; $5 \%$ black to brown, very fine to coarse phosphate nodules.

Tan and light gray microcrystalline, hard, tight, silty, dolomite, with scattered sand and phosphate.

$60 \%$ light gray, clear to frosted, fine-to mediumgrained, sub-angular quartz sand; $25 \%$ light tan and light gray mottled, soft clay matrix; $15 \%$ black to brown, fine to coarse phosphate nodules.

$60 \%$ off-white and light tan mottled, soft, crumbly, calcareous clay matrix; $35 \%$ black to brown, fine to very coarse phosphate nodules; $5 \%$ white, clear, fineto medium-grained quartz sand.

No sample.

$85 \%$ white, indurated, calcareous clay matrix; trace of phosphate; $15 \%$ sand, as above; trace of light gray and light brown mottled cryptocrystalline, hard, tight, silicified limestone fragments.

$80 \%$ dark and light green mottled, hard waxy clay matrix; $20 \%$ white, clear, fine-grained, angular, well sorted, quartz sand; trace of brown, fine to coarse, phosphate nodules; trace of cream colored and light gray mottled, hard, very fine to micr ocrystalline, tight dolomite fragments. 
$113.5-115.5$

$115.5-119.0$

$119.0-120.0$

$120.0-120.5$

$120.5-121.0$

$121.0-122.0$

$122.0-123.5$

$123.5-127.5$

$127.5-130.5$

$130.5-133.2$

$133.2-138.2$
No sample.

Light, medium green mottled, hard, fine, crystalline, porous, poorly consolidated dolomite; trace of brown to gray, fine to very coarse phosphate nodules.

Light green, hard, fine, crystalline, porous dolomite; trace of white, clear, fine-to mediumgrained, angular quartz sand, black to brown, fine to coarse phosphate nodules.

White, hard, porous, chalky limestone; trace of fine to coarse phosphate nodules, white, clear, fine-to medium-grained, angular quartz sand.

$80 \%$ medium-grained, soft, crumbly, waxy clay matrix; $10 \%$ sand, as above; $10 \%$ black to brown, fine to coarse phosphate nodules.

$75 \%$ white, soft, crumbly, calcareous clay matrix; $15 \%$ sand, as 120.0-120.5 interva1; $10 \%$ phosphate as $120.5-$ 121.0 interval.

$55 \%$ medium green, soft clay matrix; $30 \%$ light gray, clear, medium-grained, fairly we11 sorted, subrounded quartz sand; $15 \%$ multicolored, fine to very coarse phosphate nodules.

No sample.

$75 \%$ light greenish gray, soft, silty clay matrix; $15 \%$ white, fine-grained, well sorted, angular quartz sand; $10 \%$ light gray, very fine-grained, hard, tight, dolomite; trace of phosphate.

$50 \%$ sand, as above; $45 \%$ medium brownish gray, soft, crumbly clay matrix; $5 \%$ multicolored, fine to very coarse phosphate nodules and phosphatized fossil material.

$75 \%$ light gray, fine-grained, angular, well sorted quartz sand; $20 \%$ medium brown, soft, fairly well consolidated clay matrix; becomes silty and brownish gray in lower 3 feet; $5 \%$ black to brown, fine to very coarse, phosphate nodules and phosphatized fossil material. 


\section{$\underline{\text { Rocks of Oligocene Age }}$}

$138.2-144.0$

Coquina; $60 \%$ cream colored, microcrystalline, hard, porous, limestone matrix; 40\% large to small fossils, fossil molds, and fossil casts, weathered.

\section{Rocks of Eocene Age}

$144.0-164.0$

$70 \%$ light gray, microcrystalline, hard, porous limestone; $30 \%$ fossils; contains Rotalia mexicana mecatepcensis (Nutta11), and Lepidocyclina ocalana floridana (Cushman). 
PK7421

Polk County $\quad 281008$ N0815810.1

DEPTH INTERVAL (feet)

$0.0-2.0$

$2.0-5.5$

$5.5-13.0$

$13 \cdot 0-14.0$

$14 \cdot 0-15 \cdot 5$

$15 \cdot 5-19.5$

$19.5-23.5$

$23.5-25.5$

$25.5-29.0$

\section{LITHOLOGY}

\section{Post Miocene Rocks}

Light gray to light brown, clear to stained, mediumto fine-grained, angular to sub-rounded quartz sand; trace of medium gray clay.

95\% sand, as above; 5\% medium brown, soft, crumb1y clay matrix; abundant plant roots.

$60 \%$ white, frosted, medium-grained, fairly well sorted, rounded quartz sand; $30 \%$ off-white indurated clay matrix; $10 \%$ fine-grained sand; trace of heavy minerals and coarse-grained sand.

$75 \%$ 1ight gray, frosted, medium-grained, well sorted, sub-rounded quartz sand; $25 \%$ off-white, indurated, crumbly clay matrix; trace of heavy minerals.

$60 \%$ very light gray, indurated, somewhat platey clay matrix with minor, very pale green banding; $40 \%$ white, clear to frosted, fine-to medium-grained, angular to sub-angular quartz sand.

$80 \%$ white, frosted, medium-grained, well sorted, sub-rounded quartz sand; $20 \%$ white, indurated clay matrix; trace of heavy minerals.

$80 \%$ white, clear to frosted, fine-to medium-grained, angular to sub-rounded quartz sand; $20 \%$ very light tan and off-white, indurated clay matrix; trace of heavy minerals.

\section{Rocks of Miocene Age}

$80 \%$ light green, hard clay matrix; $15 \%$ sand, as above, $5 \%$ white, fine to very coarse phosphate nodules; trace of hard shell fragments that have been silicified.

$65 \%$ very light green, hard clay matrix; $35 \%$ sand, as 19.5-23.5 interval; trace of hard shell fragments. 
$29.0-31.0$

$31.0-36.5$

$36.5-38.0$

$38.0-41.5$

$41.5-43.5$

$43.5-46.5$

$46.5-48.5$

$48.5-50.5$

$50.5-56.6$

$56.5-58.5$
$60 \%$ very light gray, clear to frosted, fine-grained, angular, very well sorted quartz sand; $40 \%$ medium brown, light greenish gray, and light brown mottled, hard, platey clay matrix with scattered pockets of white, hard, well consolidated clay; trace of heavy minerals.

$50 \%$ light green, light brown and white banded, indurated clay matrix with isolated bands of black and brick red organic material; $30 \%$ medium-grained sand; $20 \%$ white to tan, clear to stained, fine-to very fine-grained, angular, fairly well sorted quartz sand; a 2-inch band of white clay at 35.8 feet.

Alternating beds of sand, as above, with light green, light brown, and yellow, hard, waxy clay.

$50 \%$ sand, as $31.0-36.5$ interval; $30 \%$ light grayish green, dull yellow, and brownish green, hard clay matrix.

$60 \%$ white, clear to frosted, fine-grained, angular, we11 sorted quartz sand; $40 \%$ tan and light green mottled, hard clay matrix; trace of white, fine to medium phosphate nodules.

0live green and medium brown mottled, hard, waxy, platey clay.

$50 \%$ sand, as $41.5-43.5$ interval; $50 \%$ light and medium tan, banded clay matrix; trace of brown phosphate blades.

Light greenish yellow, soft, well consolidated siltstone, mottled by olive green, soft, waxy clay and medium brown soft waxy clay; trace of fine-to mediumgrained sand and brown phosphate nodules.

$85 \%$ white, clear to frosted, fine-grained, angular, very we11 sorted, quartz sand; $10 \%$ light grayish green and dull yellow mottled, soft clay matrix; $5 \%$ medium-grained sand; trace of multicolored, fine to coarse phosphate blades.

$60 \%$ light green and cream colored, mottled, soft, waxy clay matrix; $35 \%$ sand, as above; $5 \%$ phosphate nodules and blades. 
$58.5-59.5$

$60 \%$ off-white and medium green mottled, soft clay matrix; $40 \%$ white, clear to frosted, fine-grained, angular, very well sorted quartz sand; trace of brown, fine to coarse, phosphate nodules and blades.

Rocks of 0ligocene Age

$59.5-67.0$

$80 \%$ off-white, soft, poorly consolidated, calcareous clay matrix; $20 \%$ off-white, microcrystalline, indurated, porous, chalky limestone; trace of fossil material; contains Rotalia mexicana mecatepcensis (Nutta11).

67.0-69.2 No sample. 


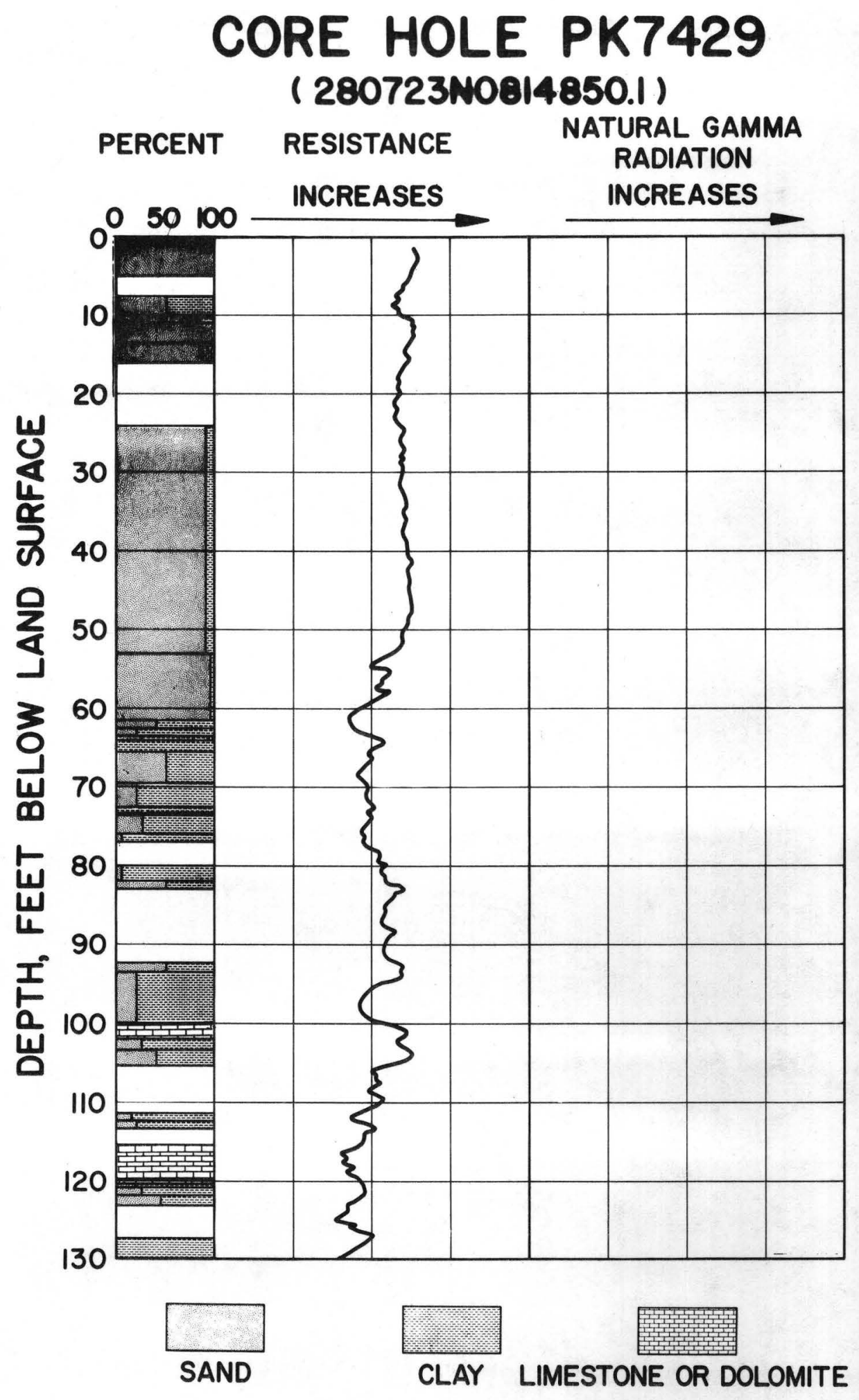




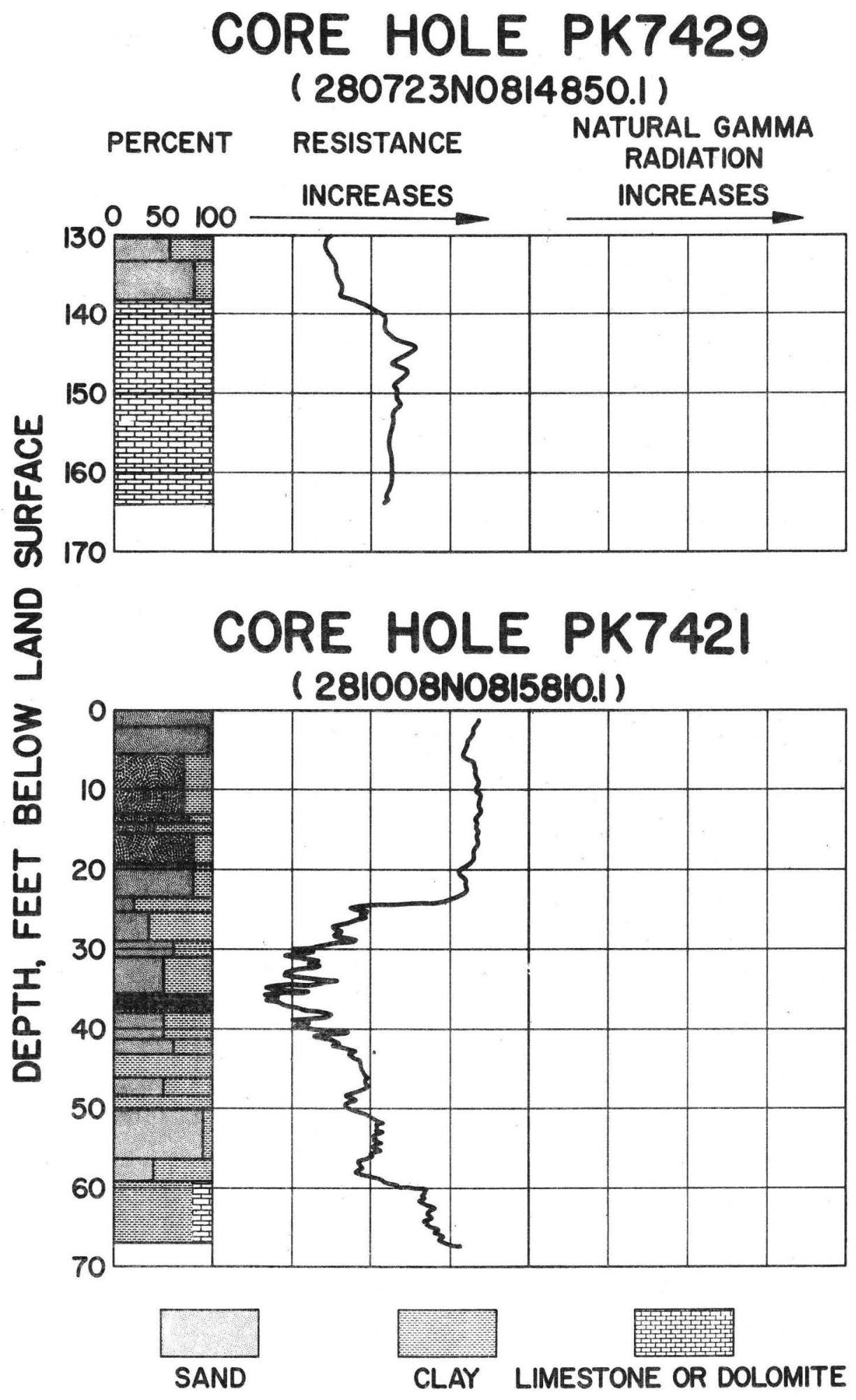


PK7433

Polk County 281045N0813908.1

DEPTH INTERVAL (feet)

$0.0-6.0$

$6.0-8.0$

$8.0-8.5$

$8.5-9.0$

$9.0-12.0$

$12.0-15.0$

$15.0-16.5$

$16.5-19.7$

$19.7-24.0$

$24.0-28.0$

\section{LITHOLOGY}

\section{Post Miocene Rocks}

Brown to yellow, medium-to coarse-grained, quartz sand.

$60 \%$ white and yellow, clear to stained, fine-to medium-grained, angular to sub-rounded quartz sand; $40 \%$ light brown to off-white indurated clay matrix; trace of heavy minerals.

$60 \%$ sand, as above; $40 \%$ du11 ye11ow and brick red mottled, indurated clay matrix; trace of heavy minerals.

$50 \%$ white and pink, clear to stained, fine-to medium-grained, angular to sub-rounded quartz sand; $50 \%$ brick red, indurated clay matrix, with minor mottling by du11 yellow and white clay; trace of heavy minerals.

$50 \%$ sand, as above; $50 \%$ cream colored and orange mottled and banded, indurated clay matrix; trace of heavy minerals.

$60 \%$ deep brick red and off-white mottled, indurated clay matrix; $25 \%$ white to red, clear to stained, medium-grained, sub-rounded, fairly well sorted quartz sand; $15 \%$ fine-grained sand; trace of heavy minerals.

$55 \%$ sand, as above; $45 \%$ brick red, indurated clay matrix.

No sample.

$90 \%$ white and ye11ow, clear to stained, mediumgrained, sub-angular to sub-rounded quartz sand; $10 \%$ off-white to yellow, soft clay matrix; trace of heavy minerals.

No sample. 
$28.0-29.2$

$29.2-31.5$

$31.5-32.2$

$32.2-32.5$

$32.5-33.0$

$33.0-34.0$

$34.0-35.0$

$35.0-38.5$

$38.5-51.5$

$51.5-54.5$
$65 \%$ white, clear to frosted, medium-grained, subrounded, fairly well sorted quartz sand; $30 \%$ white and cream colored, mottled, soft, crumbly clay matrix; $5 \%$ coarse-grained sand; trace of heavy minerals.

95\% maroon and golden brown mottled, soft, waxy clay matrix with minor light gray and dull yellow mottling; $5 \%$ light gray, clear to frosted, medium-grained, subrounded, fairly well sorted sand.

$80 \%$ white, frosted, medium-grained, fairly well sorted, sub-rounded quartz sand; $20 \%$ light brown to off-white, indurated clay matrix; trace of heavy minerals.

95\% light yellow and very dark brown mottled, waxy clay matrix; 5\% white and yellow, clear to frosted, medium-grained, fairly well sorted, sub-rounded quartz sand; trace of heavy minerals.

$65 \%$ brick red, soft clay matrix with minor yellow mottling; $35 \%$ sand as above.

95\% 1ight brown and white mottled, soft, waxy clay matrix; $5 \%$ white to yellow sand as $32.2-32.5$ interval.

$90 \%$ white, orange, and yellow, clear to stained, fine-grained, well sorted, angular quartz sand; $10 \%$ bright yellow, soft clay matrix; trace of heavy minerals.

$80 \%$ white, clear to frosted, fine-grained, angular, well sorted quartz sand; $20 \%$ orange, soft clay matrix with minor pink and yellow mottling; trace of heavy minerals.

$75 \%$ sand, as above; $25 \%$ multicolored $1 / 16$ to 1 -inch wide bands of white, red, orange, yellow and pink, soft clay matrix.

$80 \%$ white, yellow and orange, clear to stained, finegrained, angular, fairly well sorted quartz sand; $20 \%$ light yellow, soft clay matrix with minor orange and white mottling; trace of heavy minerals. 
$54.5-60.0$

$60.0-66.0$

$66.0-74.5$

$74.5-81.0$

$81.0-84.0$

$84.0-89.2$

$89.2-92.5$

$92.5-96.0$

$96.0-97.2$

$97.2-98.0$

$98.0-98.2$
$75 \%$ white, pink tinted, fine-grained, clear to stained, angular, well sorted quartz sand; $25 \%$ white, light brick red and minor yellow, soft clay matrix in $1 / 16$-inch bands.

$85 \%$ white, clear to frosted, fine-grained, angular, well sorted quartz sand; 15\% light yellow and white banded, indurated, crumbly clay matrix; bands are $1 / 16$ to $1 / 4$-inch wide; trace of heavy minerals.

$85 \%$ white to light yellow, clear to stained, finegrained, angular, well sorted quartz sand; $15 \%$ white, yellow, and light brown mottled and banded soft clay matrix; trace of heavy minerals and fine to medium phosphate nodules.

\section{Rocks of Miocene Age}

$80 \%$ sand, as above; $20 \%$ white and yellow banded and mottled, soft clay matrix; trace of organic material at 77.2 feet; bands are $1 / 16$ to $1 / 4$-inch wide.

$65 \%$ sand, as $66.0-74.5$ interval; $35 \%$ white and light brick red, banded and mottled, soft clay matrix; bands are $1 / 16$ to $1 / 4$-inch wide.

$75 \%$ white, clear, fine-grained, angular, well sorted quartz sand; $25 \%$ pink, white, brick red and yellow mottled and banded, soft clay matrix; trace of fine to medium muscovite.

$75 \%$ sand, as above; $25 \%$ off-white and yellow banded, soft clay matrix; trace of muscovite.

No sample.

$45 \%$ brown and grayish brown mottled, soft, crumbly clay matrix; $30 \%$ multicolored fine to very coarse phosphate nodules and phosphatized fossil materia1; $25 \%$ white, clear, medium-to fine-grained, subrounded to angular quartz sand.

$50 \%$ light grayish brown, soft clay matrix with minor mottling by very pale green, soft, waxy clay; $25 \%$ sand, as above; $25 \%$ phosphate as above.

White to yellow, clear to stained, fine-grained, angular, well sorted quartz sand; just enough light orange clay to bind sand very loosely. 
$98.2-101.5$

$101.5-106.2$

$106.2-106.5$

$106.5-107.0$

$107.0-115.0$

$115.0-160.0$
Same as 97.2-98.0 interval.

$50 \%$ light brownish gray, soft clay matrix; $30 \%$ white, clear, medium-grained, fairly well sorted, sub-angular quartz sand; $20 \%$ brown to light tan, fine to very coarse phosphate nodules and phosphatic fossil material.

$75 \%$ light greenish gray, soft, waxy clay matrix; $20 \%$ white, clear, fine-to medium-grained, angular to sub-angular quartz sand; $5 \%$ dark brown, fine to very coarse phosphate nodules and phosphatic fossil material; sand and phosphate occur as 1/4-inch bands within the clay.

$70 \%$ 1ight yellow and white mottled, soft, silty matrix; $25 \%$ white, clear, frosted, fine-grained, angular, fairly well sorted quartz sand; $5 \%$ phosphate, as above.

No sample.

\section{Rocks of Eocene Age}

$50 \%$ cream colored, microcrystalline, soft, porous, chalky limestone; $50 \%$ small to very large fossils and shell fragments; highly weathered; contains Sphaerogypsina globula (Reuss), Lepidocyclina ocalana floridana (Cushman), and Stromatorbina kendrickensis (Puri). 
PK7417

Polk County 281341N0815521.1

DEPTH INTERVAL (Feet)

$0.0-6.0$

$6.0-6.5$

$6.5-11.0$

$11.0-13.0$

$13.0-19.0$

$19.0-23.0$

$23.0-26.0$

$26.0-31.0$

$31.0-35.0$

\section{LITHOLOGY}

\section{Post Miocene Rocks}

No sample.

$60 \%$ white, clear, fine-grained, we11 sorted, angular quartz sand; $40 \%$ light greenish gray, soft clay matrix; trace of fine grained glauconite.

$75 \%$ white, clear to frosted, medium-grained, fairly we11 sorted, sub-rounded quartz sand; $25 \%$ tan, soft clay matrix; trace of heavy minerals.

$70 \%$ sand, as above; $30 \%$ light brown to tan, soft clay matrix.

$70 \%$ white, clear, fine-grained, well sorted, angular quartz sand; $30 \%$ light gray to tan, indurated clay with white mottling in lower 1 foot; trace of heavy minerals.

$50 \%$ white, clear to frosted, fine-to medium-grained, fairly well sorted, sub-angular to sub-rounded quartz sand; $50 \%$ light bluish green and white mottled, soft clay matrix; trace of heavy minerals and coarsegrained sand.

$80 \%$ sand, as above but mostly fine-grained; $20 \%$ light bluish gray and off-white mottled, soft clay matrix; trace of heavy minerals.

$80 \%$ white, clear, fine-grained, well sorted, angular quartz sand; $20 \%$ very light bluish green to very pale green, soft clay matrix; trace of heavy minerals.

$60 \%$ very light greenish gray and dark brown mottled, soft clay matrix; $40 \%$ white to brown, clear to frosted, fine-to medium-grained, fairly well sorted, angular to sub-rounded quartz sand; trace of heavy minerals; fine-grained sand occurs in the light greenish gray clay and medium-grained sand occurs in the dark brown clay. 
$35.0-41.0$

$41.0-44.5$

$44 \cdot 5-48.0$

$48.0-53.0$

$53.0-63.0$
$80 \%$ white, clear, fine-grained, well sorted, angular quartz sand; $20 \%$ very light gray, soft clay matrix; trace of heavy minerals.

\section{Rocks of Miocene Age}

$60 \%$ white, clear, fine-to medium-grained, fairly we11 sorted, sub-angular quartz sand; $40 \%$ very light, greenish gray, soft clay matrix with many pockets of pure clay; trace of heavy minerals, fossils and tan, medium, phosphate nodules.

$60 \%$ brownish gray and light to medium gray, tan and greenish mottled, soft, sticky clay matrix; $30 \%$ white, clear, fine-to medium-grained, fairly well sorted, angular to sub-rounded quartz sand; $10 \%$ light gray to black, very coarse to very fine, phosphate nodules and phosphatic fossil material.

\section{Rocks of Eocene Age}

$80 \%$ tan, soft, poorly consolidated, calcareous clay matrix; $20 \%$ cream to light tan, microcrystalline, indurated, porous limestone fragments, with abundant fossils and trace of medium to coarse phosphate; contains Sphaerogypsina globula (Reuss), Textularia ocalana (Cushman), Jugosocythereis bicarinata (Swain), and Stromatorbina kendrickensis (Puri).

No sample. 


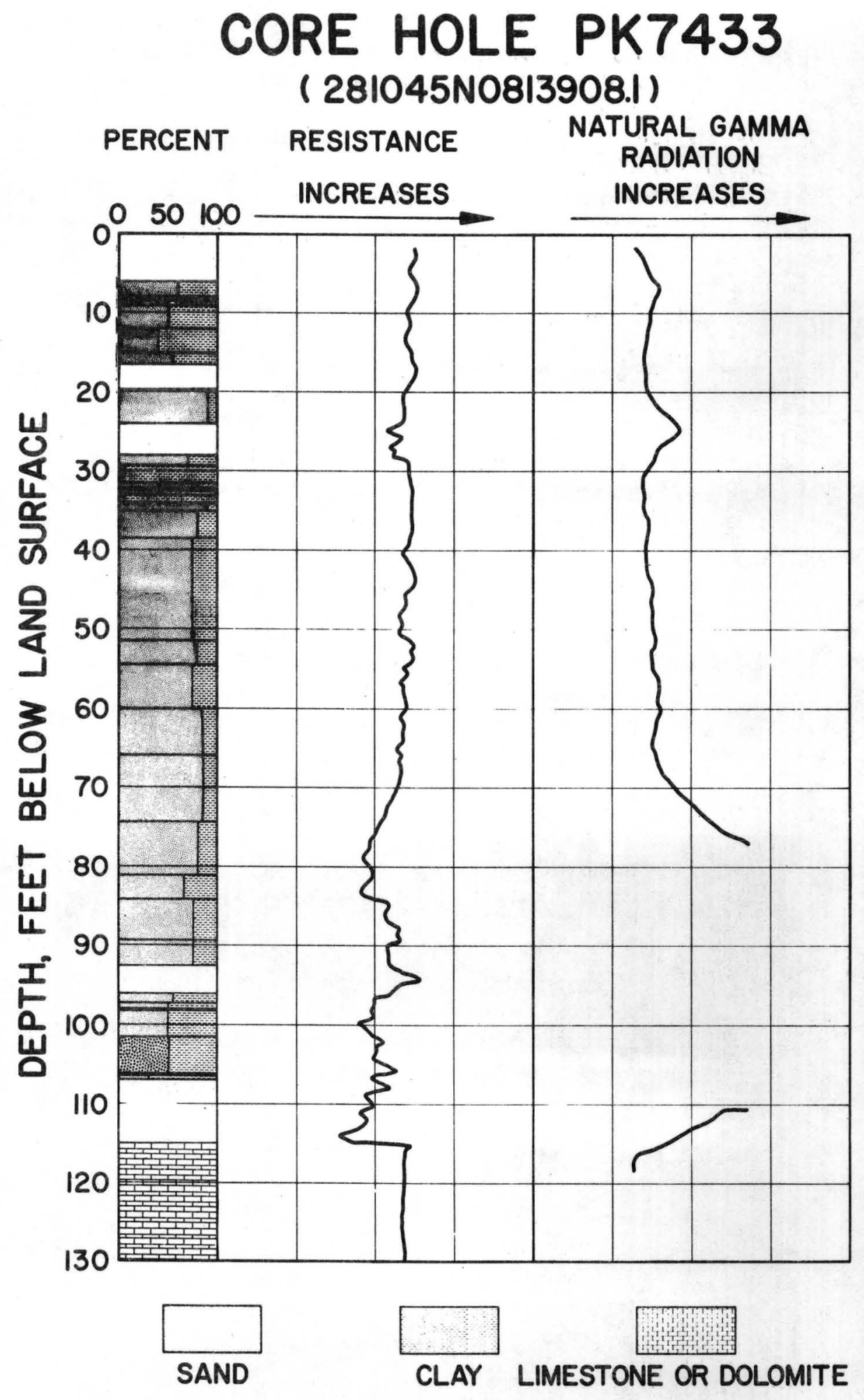




\section{CORE HOLE PK7433}

\section{( 281045N0813908.I)}

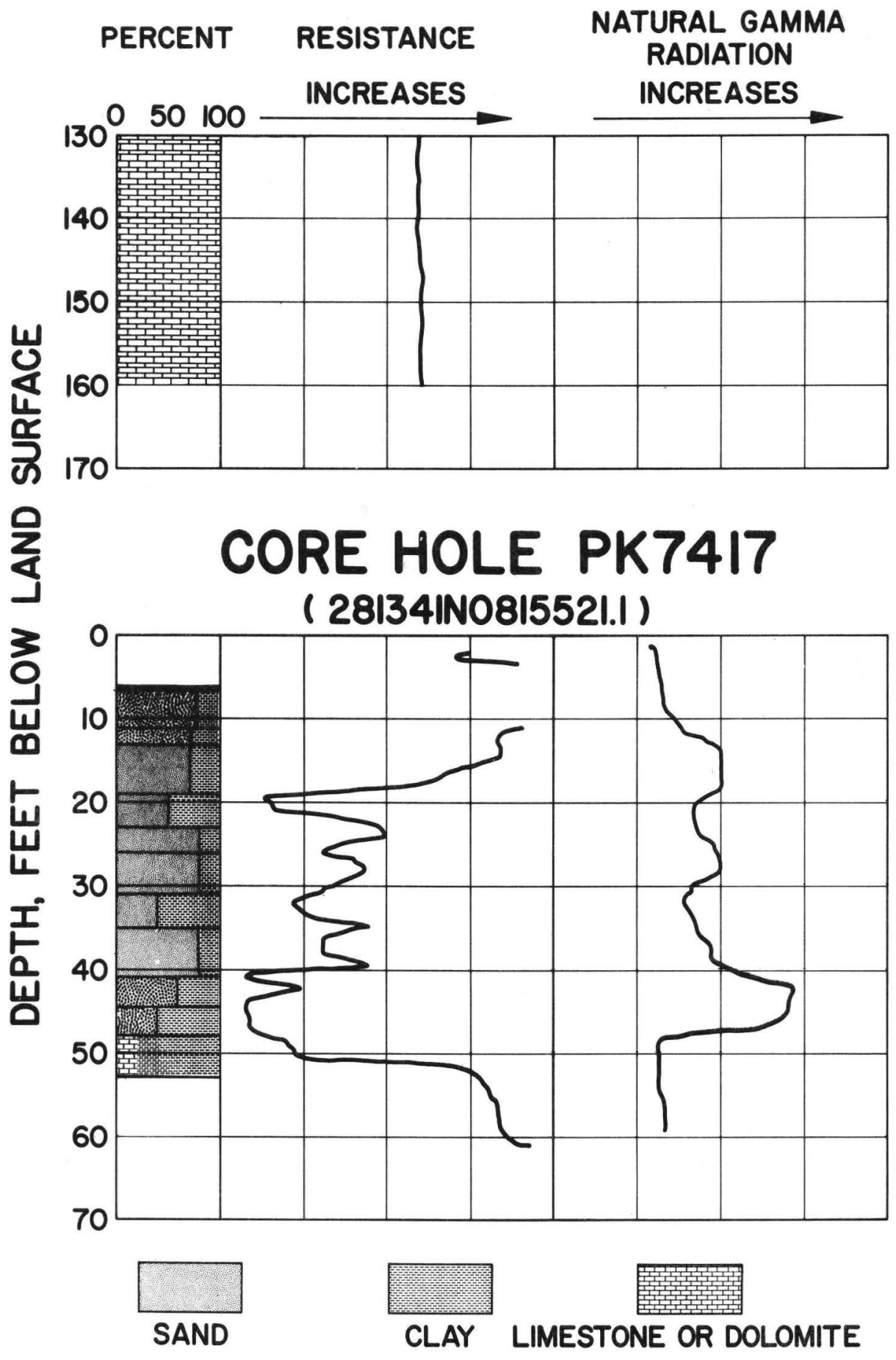


PK7430

Po1k County 281306N0814322.1

DEPTH INTERVAL (feet)

$3.0-8.0$

$8.0-11.5$

$11.5-20.0$

$20.0-34.0$

$34.0-39.0$

$39.0-45.0$

$45.0-48.0$

$48.0-61.0$

$61.0-63.0$

\section{LITHOLOGY}

\section{Post Miocene Rocks}

White to light gray, clear to frosted, mediumgrained, poorly sorted, sub-rounded quartz sand; trace of light brown and dark gray clay.

$75 \%$ very 1ight gray, soft, waxy clay matrix; $25 \%$ white, frosted, medium-grained, fairly well sorted, subrounded quartz sand; trace of heavy minerals.

$80 \%$ white, clear to frosted, fine-to medium-grained, fairly well sorted, sub-angular quartz sand; $20 \%$ very light tan, soft clay matrix with gray tint; trace of heavy minerals.

$85 \%$ sand, as above; $15 \%$ light tan, soft clay matrix; trace of heavy minerals.

$90 \%$ sand, as $8.0-11.5$ interval; $10 \%$ tan, soft clay matrix; trace of heavy minerals.

$85 \%$ white, clear to frosted, fine-to medium-grained, fairly well sorted, sub-angular quartz sand; $15 \%$ tan, soft clay matrix; trace of heavy minerals.

$75 \%$ sand, as above; $25 \%$ tan, soft clay matrix; trace of heavy minerals and coarse-grained sand.

$75 \%$ white, clear to frosted, coarse-to medium-grained, poorly sorted, silty quartz sand; $25 \%$ tan, soft clay matrix.

$70 \%$ white, clear to frosted, fine-to medium-grained, fairly well sorted, angular to sub-rounded, silty quartz sand; $30 \%$ tan, soft clay matrix; trace of heavy minerals.

$75 \%$ sand, as above; $25 \%$ tan, light gray tinted, soft clay that has medium brown streaks in the lower 1/2foot; trace of heavy minerals. 
$63.0-68.0$

$80 \%$ white to light gray, clear, medium-grained, well sorted, sub-angular quartz sand; $20 \%$ dark gray, soft clay matrix.

\section{Rocks of Miocene Age}

$68.0-72.0$

$75 \%$ white to light gray, clear to frosted, mediumgrained, fairly well sorted, sub-rounded quartz sand; $25 \%$ medium gray, soft, poorly consolidated clay matrix; one 2-inch fragment of medium brown cryptocrystalline, hard, fairly tight, silicified limestone, with tan fossiliferous material near the bottom of this interva1; trace of heavy minerals and white gypsum.

\section{Rocks of Eocene Age}

$72.0-73.0$

Medium brown, cryptocrystalline, hard, silicified limestone, contains Sphaerogypsina globula (Reuss), Lepidocyclina ocalana floridana (Cushman), Cibicides mississippiensis ocalanus (Cushman), and Echinocythereis okeechobiensis (Swain).

$73.0-78.0$

$50 \%$ tan, microcrystalline, soft, porous, chalky limestone; $50 \%$ tan, soft, poorly consolidated calcareous clay matrix; contains abundant fossils.

$78.0-84.0$

No sample. 


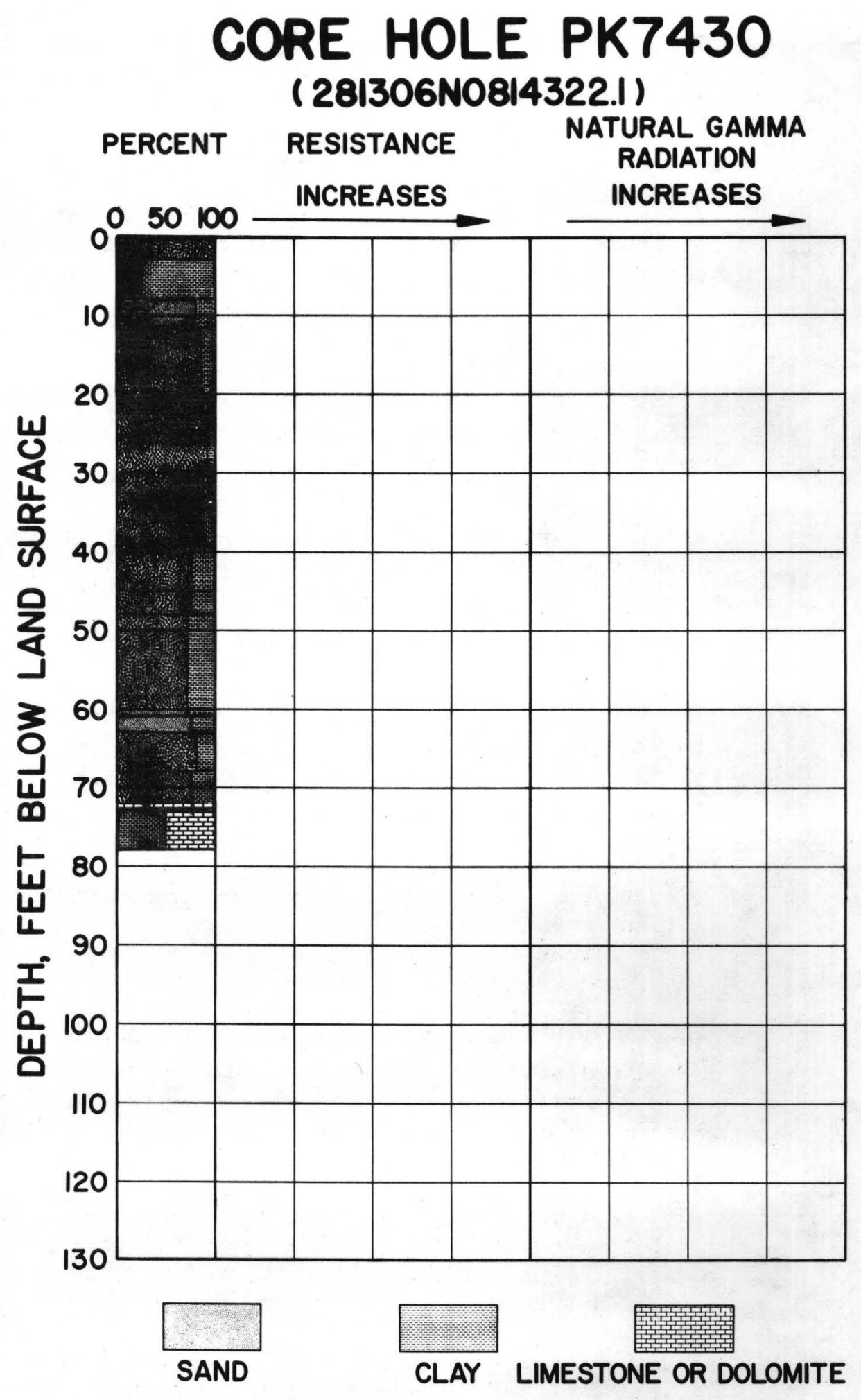


Polk County 281317N0814913.3

DEPTH INTERVAL (feet)

$0.0-4.0$

$4.0-10.5$

$10.5-14.5$

$14.5-16.0$

$16.0-18.5$

$18.5-20.0$

$20.0-21.0$

$21.0-37.0$

$37.0-42.5$

$42.5-44.5$

\section{LITHOLOGY}

\section{Post Miocene Rocks}

$80 \%$ white to light brown, clear to stained, mediumgrained, fairly we11 sorted, sub-rounded quartz sand; $10 \%$ fine-grained sand; $10 \%$ medium gray and medium brown mottled, soft clay matrix.

$75 \%$ very 1 ight gray, indurated porous siltstone; $15 \%$ white, clear, fine-to medium-grained, sub-rounded quartz sand; $10 \%$ black, medium to very coarse phosphate nodules.

$55 \%$ indurated, off-white, clay matrix; $45 \%$ white, clear to frosted, medium-grained, fairly well sorted, sub-angular to sub-rounded quartz sand.

No sample.

$75 \%$ white, clear to frosted, coarse-to medium-grained, sub-angular to rounded quartz sand; $25 \%$ very 1 ight tan, indurated clay matrix; trace of heavy minerals.

$80 \%$ sand, as above; $15 \%$ very light tan to off-white, indurated, crumbly clay matrix; $5 \%$ very coarsegrained sand; trace of heavy minerals.

No sample.

$75 \%$ white, clear to frosted, medium-grained, fairly well sorted, sub-rounded quartz sand; $20 \%$ very light tan, indurated clay matrix; 5\% fine-grained sand; trace of heavy minerals and coarse-to very coarsegrained sand.

95\% white, clear to frosted, coarse-to medium-grained, sub-rounded quartz sand; $5 \%$ off-white, soft clay matrix; trace of heavy minerals and very coarsegrained sand.

$90 \%$ sand, as above; $5 \%$ fine-grained sand; $5 \%$ very light tan, soft clay matrix; trace of heavy minerals. and fine to medium muscovite. 
$44 \cdot 5-49 \cdot 0$

$49 \cdot 0-53.0$

$53.0-56.0$

$56.0-61.5$

$61 \cdot 5-62 \cdot 5$

$62.5-63.5$

$63 \cdot 5-64.2$

$64.2-65.0$

$65.0-68.0$

$68.0-71.0$
$80 \%$ white, clear to frosted, fine-grained, fairly we11 sorted, angular quartz sand; $15 \%$ off-white soft clay matrix; $5 \%$ medium-to coarse-grained sand; trace of heavy minerals and fine to medium muscovite.

95\% white, clear to frosted, fine-grained, angular, we11 sorted quartz sand; $5 \%$ off-white, soft clay matrix; trace of fine to medium muscovite and coarsegrained sand.

No sample.

$70 \%$ sand, as $49.0-43.0$ interva $1 ; 25 \%$ medium brown to light brown, mottled, soft clay matrix; $5 \%$ mediumgrained sand; trace of muscovite and coarse-grained sand.

$65 \%$ light gray, clear to frosted, fine-grained, very we11 sorted, angular quartz sand; $30 \%$ medium brown and medium greenish gray mottled, soft clay matrix; $5 \%$ medium-grained sand; trace of fine to medium muscovite.

$75 \%$ sand, as above; $25 \%$ light gray and dark brown mottled; indurated clay matrix; trace of muscovite.

75\% light gray, clear, fine-to medium-grained, angular to sub-rounded quartz sand; $25 \%$ medium brown, soft crumbly clay matrix with minor black and light gray mottling; trace of heavy minerals.

\section{Rocks of Miocene Age}

$50 \%$ light and dark brown mottled, crumbly, soft clay matrix; $40 \%$ white, clear, fine-to medium-grained, angular to sub-rounded quartz sand; $10 \%$ light gray, medium to very coarse phosphate nodules; trace of light gray microcrystalline, hard, tight, silicified limestone fragments.

No sample.

$80 \%$ 1ight tan, light brown, dark brown, and black mottled, soft, crumbly clay matrix; $15 \%$ white, clear to frosted, fine-to medium-grained, angular to sub-rounded quartz sand; $5 \%$ light to dark gray, medium to very coarse phosphate nodules; trace of pisolitic silica. 
$71.0-71.7$

$71.7-72.2$

$72.2-74.2$

$74.2-109.0$
95\% 1ight and dark brown, and dark gray mottled, soft, crumbly clay matrix; $5 \%$ sand, as above; trace of phosphate, pisolitic silica, and brown to gray microcrystalline; hard, tight, silicified limestone fragments.

\section{Rocks of Eocene Age}

$80 \%$ cream colored, soft, poorly consolidated, ca1careous, clay matrix; 15\% cream colored, soft, porous, very fine-grained limestone; 5\% large to small foraminifera.

$55 \%$ cream colored, soft, poorly consolidated, calcareous clay matrix; $25 \%$ very light gray, microcrystalline, hard, porous limestone; $20 \%$ fossiliferous material; contains Sphaerogypsina globula (Reuss), Lepidocyclina ocalana floridana (Cushman), and Echinocythereis okeechobiensis (Swain).

$50 \%$ calcareous clay, as above; $35 \%$ large to sma11 fossils; $15 \%$ limestone, as above. 


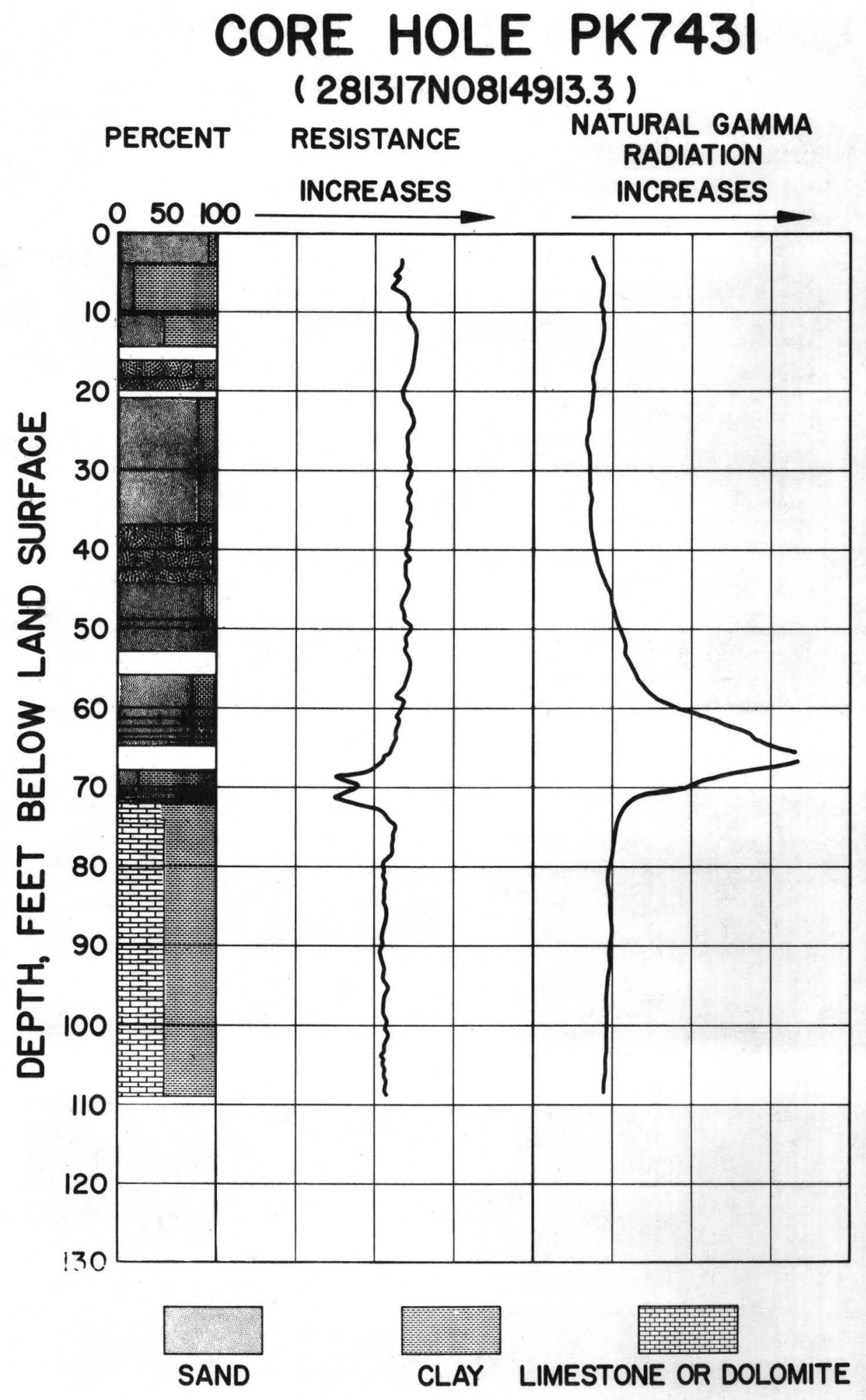


PK7434

Po1k County 281008N0814418.3

DEPTH INTERVAL (feet)

$0.0-2.0$

$2 \cdot 0-4 \cdot 0$

$4.0-8.0$

$8.0-15.0$

$15.0-24.0$

$24.0-29.5$

$29.5-31.5$

$31.5-33.5$

$33.5-47.0$

$47.0-48.5$

$48 \cdot 5-51.5$

$51.5-53.5$

\section{LITHOLOGY}

\section{Post Miocene Rocks}

Tan, stained, fine-to medium-grained, angular to sub-rounded quartz sand.

Same as above, but color is light tan.

No sample.

$45 \%$ white, clear to frosted, fine-grained, fairly well sorted, angular quartz sand; $35 \%$ white to off-white, indurated, crumbly clay matrix; $20 \%$ medium-to coarse-grained sand; trace of heavy minera1s.

$60 \%$ sand, as above; $40 \%$ off-white, indurated, crumbly clay matrix; trace of heavy minerals.

45\% white, clear to frosted, fine-grained, angular, fairly well sorted quartz sand; $30 \%$ very 1 ight tan, soft clay matrix; $25 \%$ medium-grained sand; trace of heavy minerals.

$80 \%$ sand, as above; $20 \%$ light tan, soft clay matrix.

$55 \%$ white, clear to frosted, medium-grained, fairly well sorted, sub-rounded quartz sand; $25 \%$ white, indurated clay matrix; $20 \%$ fine-grained sand; trace of heavy minerals.

$70 \%$ white, clear to frosted, fine-grained, angular, we11 sorted quartz sand; $30 \%$ very light gray, soft clay matrix; trace of heavy minerals and fine muscovite.

No sample.

$60 \%$ sand, as $33.5-47.0$ interval; $40 \%$ clay as $33.5-$ 47.0 interval; trace of heavy minerals and muscovite.

$75 \%$ sand and $25 \%$ clay as $33.5-47.0$ interval; trace of heavy minerals and muscovite. 
$53.5-54.0$

$54.0-55.0$

$55.0-55.5$

$55.5-56.0$

$56.0-56.2$

$56.2-57.2$

$57.2-58.5$

$58.5-59.5$

$59.5-62.5$

$62.5-64.5$
$85 \%$ light gray, clear to frosted, medium-to finegrained, sub-angular to rounded quartz sand; $15 \%$ light brown, indurated clay matrix with banding by dark brown, soft, waxy clay; trace of heavy minerals.

$80 \%$ sand, as above; $20 \% \tan$, soft, clay matrix; trace of heavy minerals.

$50 \%$ yellow and light to dark brown banded, soft clay matrix; bands are about 1/8-inch thick; 40\% 1ight gray, clear to frosted, fine-grained, fairly well sorted, angular quartz sand; $10 \%$ medium-grained sand; trace of heavy minerals.

$60 \%$ medium brown clay; $20 \%$ light gray, clear to frosted, medium-to fine-grained, angular to rounded quartz sand; sand is interbedded with $20 \%$ light brown clay.

$70 \%$ medium brown clay, mottled with light brown clay and sand; $30 \%$ sand, as above.

\section{Rocks of Miocene Age}

$35 \%$ light brown soft clay matrix; $35 \%$ very light tan, fine to very coarse phosphate nodules; $30 \%$ light gray clear to frosted, medium-grained, fairly well sorted, rounded quartz sand.

$40 \%$ light gray, clear to frosted, medium-grained, fairly well sorted, rounded to sub-angular quartz sand; $30 \%$ light green, soft clay matrix; $25 \%$ multicolored, fine to very coarse phosphate nodules and phosphatic fossil material; 5\% fine-grained sand.

$70 \%$ light brown, medium green and bluish green, mottled, indurated, waxy clay matrix; $20 \%$ phosphate, as above; $10 \%$ sand, as above.

$45 \%$ sand, as $57.2-58.5$ interval; $35 \%$ light brownish green, soft clay matrix; $20 \%$ phosphate as $57.2-58.5$ interval.

$60 \%$ off-white, indurated clay matrix, mottled with very pale green silt; $25 \%$ light gray, clear to frosted, fine to medium-grained, angular to sub-angular quartz sand; $15 \%$ multicolored, fine to very coarse phosphate nodules and phosphatized fossil material. 


\begin{tabular}{|c|c|}
\hline $64.5-68.5$ & No sample. \\
\hline $68.5-69.5$ & $\begin{array}{l}30 \% \text { fine-grained sand; } 25 \% \text { light gray, clear to frosted, } \\
\text { medium-grained, fairly well sorted, sub-angular quartz } \\
\text { sand; } 25 \% \text { medium brownish gray, soft crumbly clay matrix } \\
\text { with a few pockets of medium green, pure soft clay; } 20 \% \\
\text { black and brown, fine to very coarse phosphate nodules } \\
\text { and phosphatized fossil material. }\end{array}$ \\
\hline $69.5-70.5$ & $\begin{array}{l}50 \% \text { light and medium green mottled, soft, crumbly clay } \\
\text { matrix; } 35 \% \text { white, clear to frosted, fine-grained, } \\
\text { fairly we } 11 \text { sorted, angular quartz sand; } 10 \% \text { medium- } \\
\text { grained sand; } 5 \% \text { multicolored phosphate. }\end{array}$ \\
\hline $70.5-71.5$ & $\begin{array}{l}60 \% \text { sand, as } 69.5-70.5 \text { interval; } 35 \% \text { medium green, } \\
\text { tan and light green mottled, soft, crumbly clay } \\
\text { matrix; } 5 \% \text { phosphate; pockets and streaks of } 40 \% \\
\text { sand and } 60 \% \text { medium green soft clay. }\end{array}$ \\
\hline $71.5-77.0$ & $\begin{array}{l}90 \% \text { tan, soft, poorly consolidated, calcareous clay } \\
\text { matrix; } 10 \% \text { cream colored microcrystalline; trace of } \\
\text { soft, porous limestone fragments made up mostly of } \\
\text { large to small fossils. }\end{array}$ \\
\hline & Rocks of Eocene Age \\
\hline $77.0-98.8$ & $\begin{array}{l}\text { Limestone with fossils as above, highly weathered, } \\
\text { contains Lepidocyclina ocalana floridana (Cushman), } \\
\text { and Jugosocythereis bicarinata } \\
\text { (Swain). }\end{array}$ \\
\hline
\end{tabular}




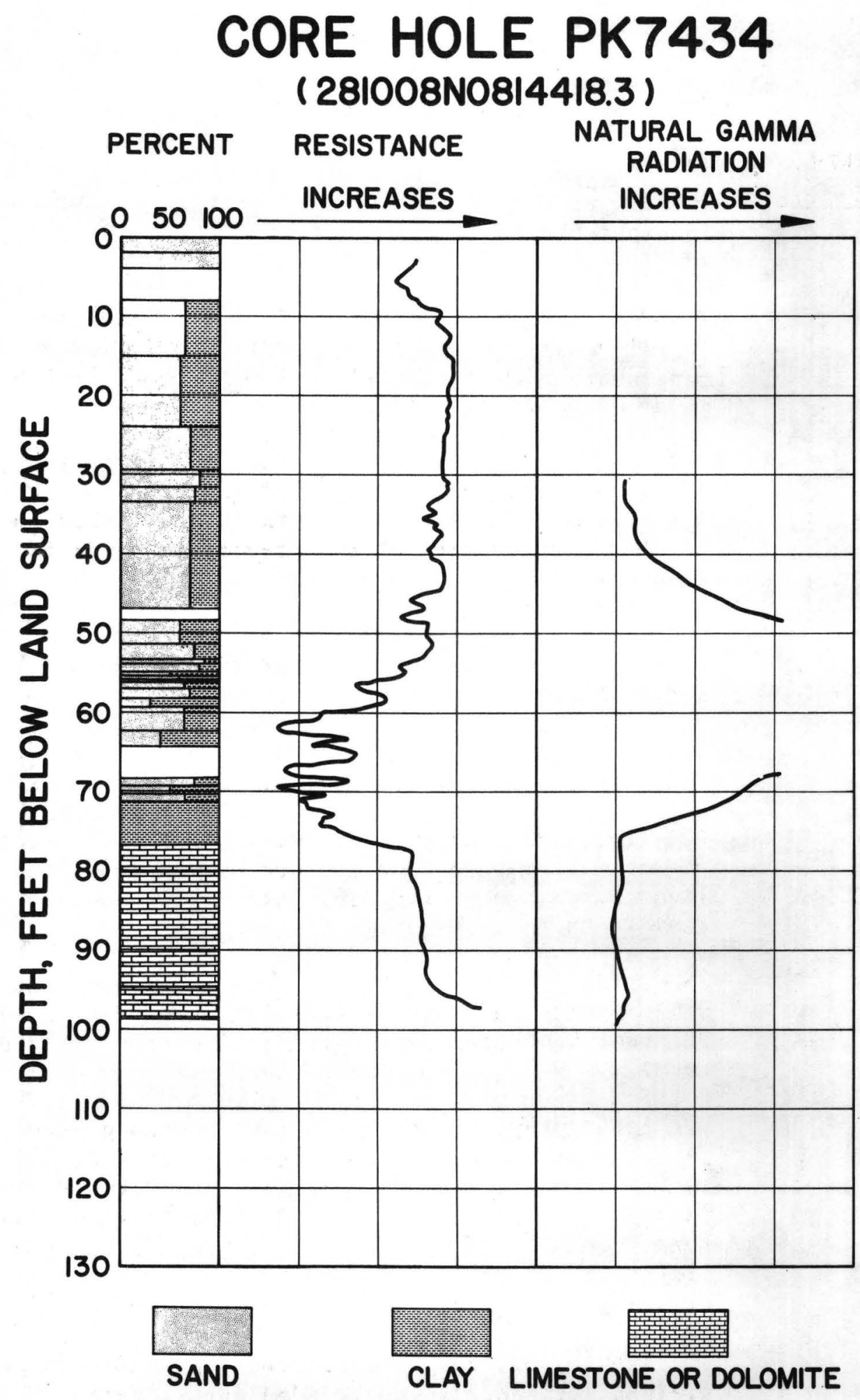


PK7435

Polk County 280927N0814028.1

DEPTH INTERVAL (feet)

$6.0-9.5$

$9 \cdot 5-15.5$

$15.5-16.5$

$16.5-23.5$

$23.5-30.5$

$30.5-33.5$

$33.5-35.0$

$35.0-38.0$

\section{LITHOLOGY}

\section{Post Miocene Rocks}

$90 \%$ light gray and light brown, clear to stained, medium-grained, fairly well sorted, sub-rounded quartz sand; $5 \%$ coarse-grained sand; $5 \%$ dark brown to light gray, soft clay matrix.

$60 \%$ light gray, clear to frosted, medium-grained, fairly well sorted, sub-rounded quartz sand; $30 \%$ light gray, dark gray, and dark brown mottled, soft crumbly clay matrix; $5 \%$ coarse-grained sand; $5 \%$ fine-grained sand.

90\% light brown, clear to stained, medium-grained, fairly well sorted, sub-rounded quartz sand; $10 \%$ medium brown, soft crumbly clay matrix.

$85 \%$ sand, as above; $15 \%$ dark and light brown mottled, indurated, crumbly clay matrix.

$70 \%$ 1ight gray, clear to frosted, medium-grained, fairly well sorted, sub-rounded quartz sand; $20 \%$ light brown, indurated clay matrix; $10 \%$ coarse grained sand.

$75 \%$ white, clear to frosted, medium-grained, fairly well sorted, sub-angular to sub-rounded quartz sand; $20 \%$ tan, indurated clay matrix; $5 \%$ coarse-grained sand.

$70 \%$ 1ight gray, clear to frosted, medium-grained, fairly well sorted, sub-angular quartz sand; $20 \%$ light brown, indurated, poorly consolidated, crumbly clay matrix; $5 \%$ coarse-grained sand; $5 \%$ fine-grained sand.

No sample.

$80 \%$ light gray, clear to frosted, medium-to coarsegrained, sub-angular to rounded quartz sand; $20 \%$ medium brown, indurated clay matrix; trace of heavy minerals. 
$38.0-40.5$

$40.5-47.0$

$47.0-51.5$

$51.5-54.0$

$54.0-73.5$

$73.5-75.0$

$75.0-76.0$

$76.0-78.0$

$78.0-78.5$

$78.5-79.2$
$80 \%$ sand, as above; $20 \%$ light brown, indurated, fairly well consolidated clay matrix; trace of heavy minerals.

$90 \%$ white, clear to frosted, medium-to coarsegrained, sub-angular to rounded quartz sand; $10 \%$ tan, indurated, fairly well consolidated clay matrix; trace of coarse-grained sand and heavy minerals.

$80 \%$ white, clear to frosted, fine-grained, we11 sorted, angular quartz sand; $20 \%$ light tan, soft clay matrix; trace of heavy minerals and fine to medium muscovite.

$70 \%$ sand, as above; $30 \%$ tan and light gray mottled, soft clay matrix; trace of heavy minerals and muscovite.

$70 \%$ light gray, clear to frosted, fine-grained, well sorted, angular quartz sand; $30 \%$ medium gray, soft clay matrix with minor light brown mottling; trace of fine to medium muscovite.

75\% light gray, clear to frosted, very fine-to medium-grained, angular to rounded quartz sand; $25 \%$ medium to light brown, soft, poorly consolidated clay matrix, mottled and banded with buff, white, and black, soft waxy clay; trace of tan to buff, medium to coarse phosphate nodules.

\section{Rocks of Miocene Age}

$55 \%$ very dark, brownish gray, soft, crumbly clay matrix; $45 \%$ white, clear to frosted, fine-to very fine-grained, well sorted, angular quartz sand.

$60 \%$ light to very dark brown, mottled, soft, crumbly clay matrix; $35 \%$ black to buff, very fine to small pebble sized phosphate nodules; $5 \%$ sand, as above.

$60 \%$ dark brown, soft waxy clay; $30 \%$ phosphate as 76.0-78. 0 interval; $10 \%$ white, clear to frosted, very fine-to medium-grained, angular to sub-rounded quartz sand.

$50 \%$ medium brown, soft, waxy clay matrix; $35 \%$ phosphate as $76.0-78.0$ interval; $15 \%$ sand as $78.0-78.5$ interval. 
$79.2-79.7$

$79.7-112.0$

$112.0-112.4$
45\% phosphate as $76.0-78.0$ interval; $40 \%$ light brown, soft, poorly consolidated clay matrix; $15 \%$ sand, as 78.0-78.5 interval.

$60 \%$ light gray and cream colored microcrystalline, hard, tight, limestone fragments, made up of $50 \%$ sand and phosphate as 76.0-78.0 and 78.0-78.5 intervals and $50 \%$ light gray to buff mottled, crumbly clay matrix; $40 \%$ light tan, clear to stained, fine-to coarse-grained, angular to rounded quartz sand; trace of black and brown, fine to very coarse phosphate nodules.

\section{Rocks of Eocene Age(?)}

Circulation lost and could not be re-established. 


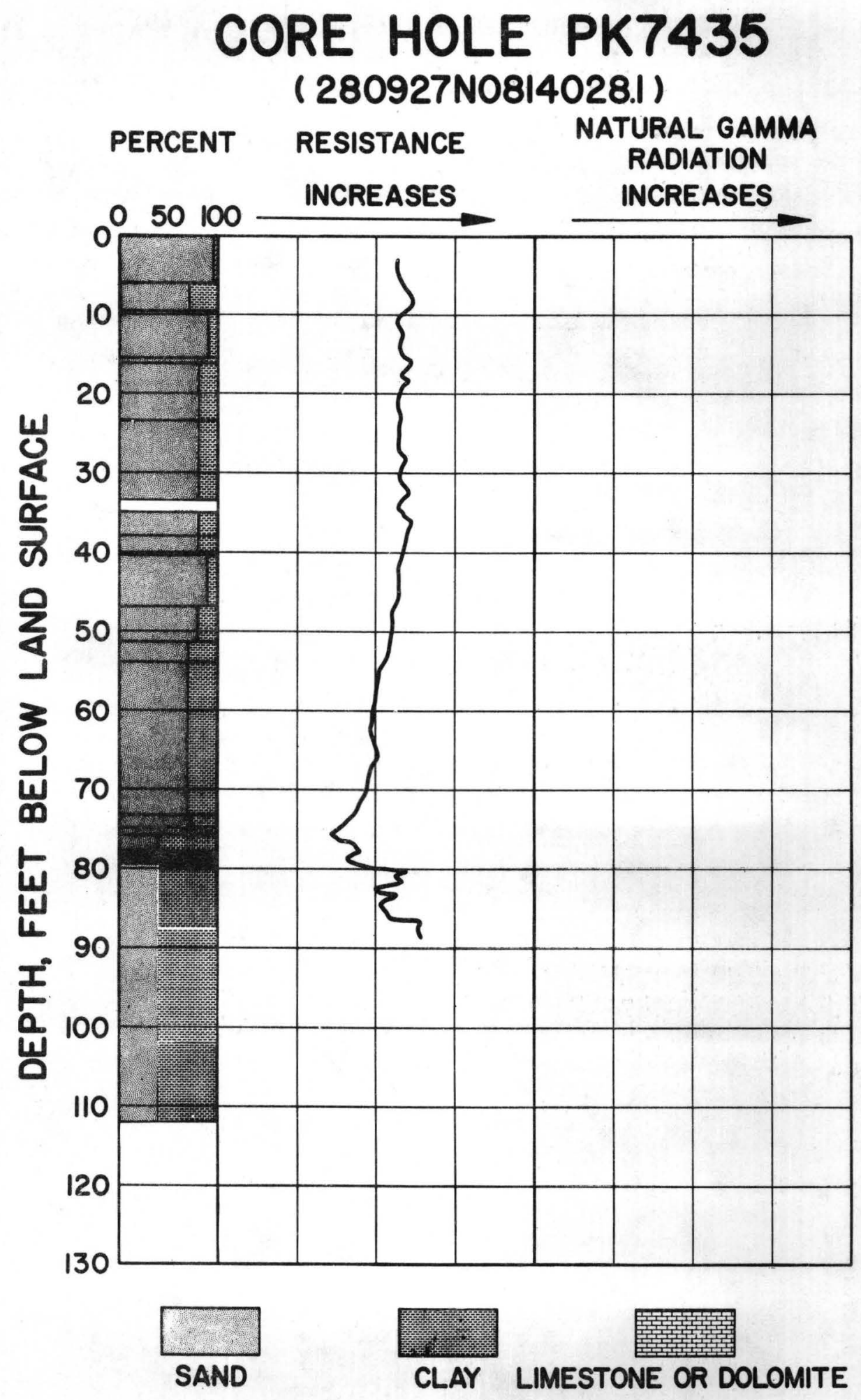




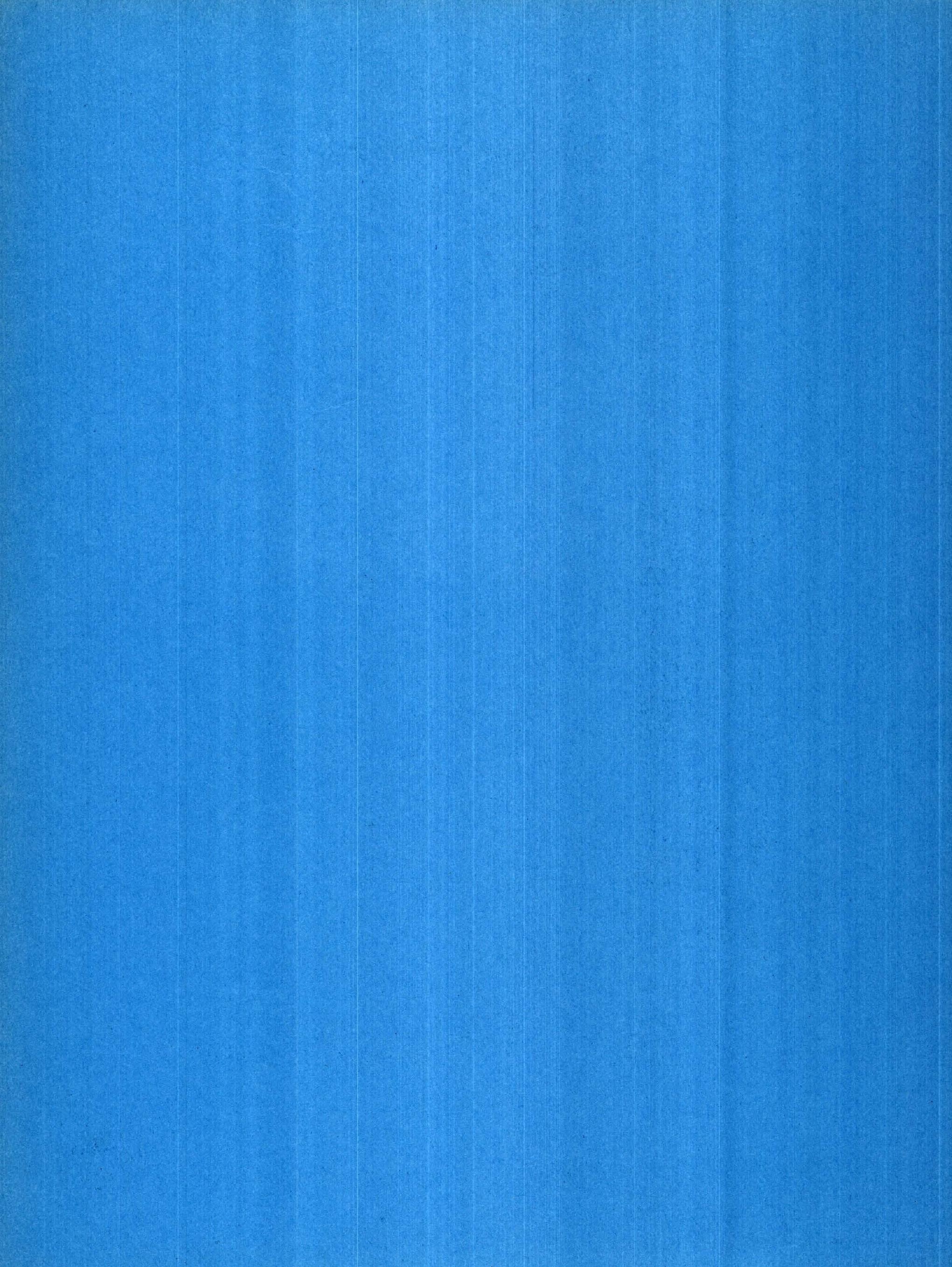


UNITED STATES DEPARTMENT OF THE INTERIOR GEOLOGICAL SURVEY

325 John Knox Rd--Suite F240

Ta1lahassee, Flor 1da 32303
POSTAGE AND FEES PAID

U.S. DEPARTMENT OF THE INTERIOR INT. 413 